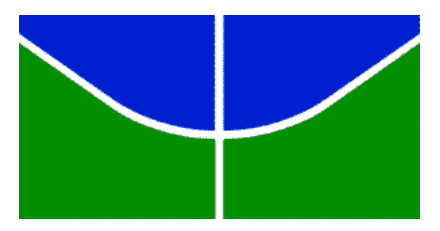

UNIVERSIDADE DE BRASÍLIA

Faculdade de Educação

Programa de Pós Graduação em Educação

Mestrado em Políticas Públicas de Educação Profissional

SUZANA CURI GUERRA

RELEVÂNCIA DO PROGRAMA MULHERES MIL PARA O CAPITAL

SOCIAL DAS PARTICIPANTES

Brasília, fevereiro de 2016. 


\section{RELEVÂNCIA DO PROGRAMA MULHERES MIL PARA O CAPITAL SOCIAL DAS PARTICIPANTES}

Dissertação de Mestrado Profissional apresentada ao Programa de Pós Graduação em Educação, da Universidade de Brasília, como requisito para obtenção do grau de Mestre em Educação.

Orientador: Prof. Dr. Remi Castioni

Brasília, fevereiro de 2016. 
Ficha catalográfica elaborada automaticamente, com os dados fornecidos pelo(a) autor(a)

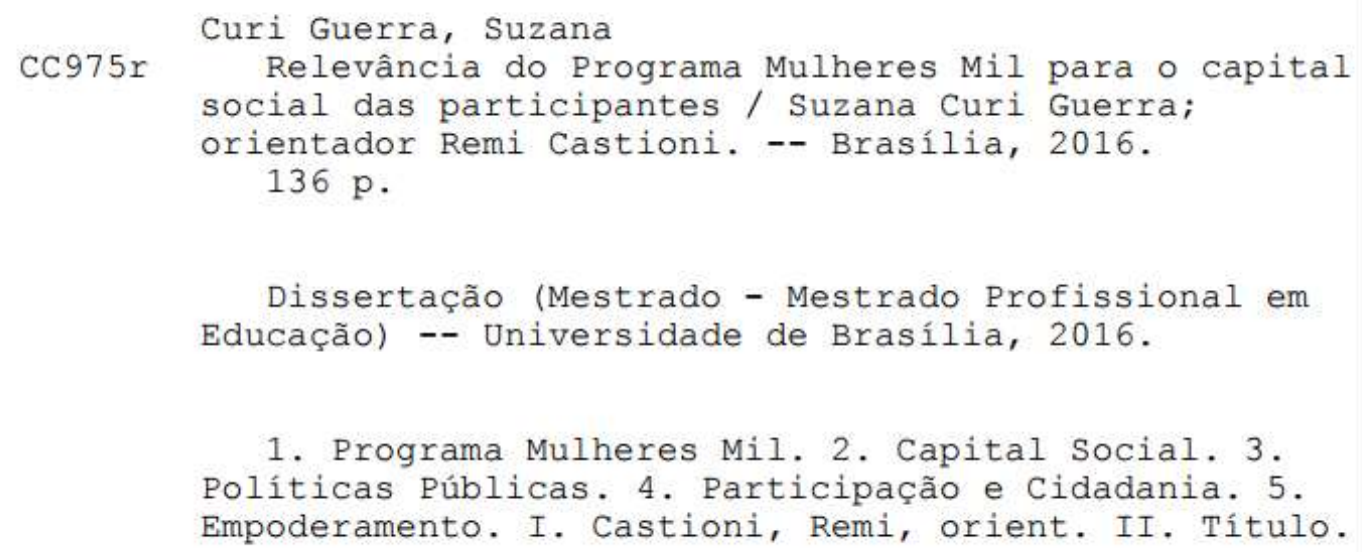

1. Programa Mulheres Mil. 2. Capital Social. 3. Políticas Públicas. 4. Participação e Cidadania. 5. Empoderamento. I. Castioni, Remi, orient. II. Título. 


\title{
RELEVÂNCIA DO PROGRAMA MULHERES MIL PARA O CAPITAL SOCIAL DAS PARTICIPANTES
}

\author{
Dissertação de Mestrado Profissional apresen- \\ tada ao Programa de Pós Graduação em Edu- \\ cação, da Universidade de Brasília, como re- \\ quisito para obtenção do grau de Mestre em \\ Educação.
}

Orientador: Prof. Dr. Remi Castioni

BRASÍLIA, DE DE 2016.

BANCA EXAMINADORA

Prof. Dr. Remi Castioni

Orientador

Profa. Dra. Maria da Conceição da Silva Freitas

Professora Examinadora

Profa. Dra. Natália de Souza Duarte

Professora Examinadora 


\section{AGRADECIMENTOS}

Aos meus pais, Viviane e Henri, e irmãos, Alice, Guilherme e Marina, por terem me oportunizado ambiente propício à curiosidade, à investigação e ao conhecimento, sempre com amor e paciência.

Ao meu companheiro José Guerra, pelo amor, compreensão, força e pelos cuidados redobrados com nossos filhos durante essa jornada.

Aos filhos amados, José, Inácio e Ester (que chegará em breve), maiores mestres que poderia ter, pela lembrança diária de que sempre se pode melhorar.

À querida amiga Déborah Proença, pelo entusiasmo que às vezes faltava, pelas inúmeras ajudas neste percurso e pela revisão realizada com tanto profissionalismo.

Ao caro professor Remi, pela confiança, pelos conhecimentos e pela cuidadosa orientação. Agradeço, também, pela compreensão e paciência nos momentos mais difíceis.

Às professoras Olgamir Carvalho e Natália Duarte, pelas preciosas e definitivas contribuições no momento da qualificação.

Aos colegas do mestrado, parceiros de angústias, alegrias, dúvidas e conhecimentos, pela carinhosa acolhida.

E, finalmente, a todas as guerreiras "Mulheres Mil", pelos incontáveis exemplos de determinação, força, fé e coragem que me levam a acreditar num mundo melhor. 


\section{RESUMO}

O Programa Mulheres Mil é uma política educacional de qualificação profissional e formação cidadã. Nos seus itinerários formativos estão previstos, além dos conteúdos relacionados à área de formação, temas relativos à formação crítica com o objetivo de elevar a autoestima, a autonomia, o empoderamento e permitir o exercício da cidadania e de direitos. O objetivo desta pesquisa é investigar a relevância do Programa Mulheres Mil para o capital social das participantes do campus Taguatinga, do Instituto Federal de Brasília, e como o curso influenciou suas vidas. Nesta pesquisa, o capital social é tomado em sua forma positiva, representando o potencial de criação de redes de apoio para a consecução de objetivos comuns. Para responder à questão central, a pesquisa se insere no campo da educação e foi conduzida de forma qualitativa, por meio de entrevistas a sete egressas do curso que evidenciaram aspectos relacionados a várias áreas de suas vidas antes e depois da participação no Programa. O referencial teórico traz conceitos e visões sobre o capital social de diversos autores, articulados com capital econômico, humano e cultural; com a educação; com a família; com o papel das mulheres e com as políticas públicas. Esta articulação de conceitos permitiu maior compreensão sobre o Programa e a análise das entrevistas permitiu verificar que o Programa Mulheres Mil foi relevante para o capital social das alunas, tendo um efeito positivo em suas vidas nas categorias do capital social investigadas: empoderamento, relações sociais, relações pessoais e participação e cidadania. A pesquisa traz como contribuição técnica sugestões para a melhoria do Programa com a finalidade de ampliar as possibilidades de geração de capital social nas alunas.

Palavras-chave: Programa Mulheres Mil. Capital social. Políticas Públicas. Participação e Cidadania. Empoderamento. 


\begin{abstract}
The Mulheres Mil Program is an educational policy of a professional qualification and citizenship formation. In its formations itineraries, themes related to the critical thinking have been foreseen, in addition to the training area content, in order to raise self-esteem, autonomy, empowerment and the ability to exercise the participant's citizenship and rights. The research's objective is to investigate the Program's relevance to the social capital of participants in campus Taguatinga of the Federal Institute of Brasília, and how the course influenced their lives. In this research, the social capital is taken in its positive form, representing the potential for creation of supportive networks to build common goals. To answer the central question, the research enters in the educational field and was conducted qualitatively, using interviews that showed subjective aspects of seven recent grads of the Program, relating their realities before and after the experience. The theoretical reference brings several authors' concepts and visions on social capital, linked to economic, human and cultural capital; also connecting it to education, family, the women's role and public policies concepts. This articulation of concepts allowed greater understanding about the Program and the interviews' analysis allowed verifying that the Mulheres Mil Program was relevant factor to the student's social capital, having a positive effect on their lives on the categories that have been investigated: empowerment, social relationships, personal relationships, citizenship and democratic participation. The research brings as contributions, suggestions for the Program improvement with the purpose of broadening the possibilities of generating social capital in the students.
\end{abstract}

Keywords: Mulheres Mil Program. Social Capital. Public Policies. Citizenship and Democratic Participation. Empowerment. 


\section{LISTA DE SIGLAS}

CRAS - Centro de Referência de Assistência Social

EJA - Educação de Jovens e Adultos

FIC - Formação Inicial e Continuada

GDF - Governo do Distrito Federal

IBGE - Intituto Brasileiro de Geografia e Estatística

IF - Instituto Federal de Educação, Ciência e Tecnologia

ONU - Organização das Nações Unidas

UnB - Universidade de Brasília

\section{LISTA DE TABELA, QUADROS E GRÁFICO}

TABELA 1 - MODELO PARA A RELAÇÃO ENTRE DESEMPENHO EM LEITURA E

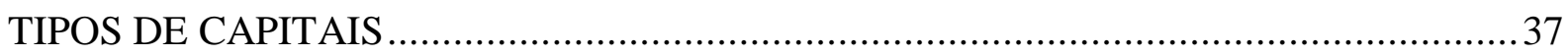

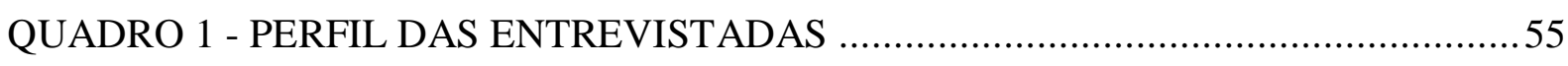

QUADRO 2 - PERFIL DOS FILHOS DAS ENTREVISTADAS …..................................55

QUADRO 3 - RELEVÂNCIA DAS CATEGORIAS POR ENTREVISTADA ...................71

QUADRO 4 - RELEVÂNCIA DE CADA CATEGORIA DE ANÁLISE .........................72

GRÁFICO 1 - RELEVÂNCIA DO PROGRAMA POR CATEGORIA DE ANÁLISE ........72 


\section{SUMÁRIO}

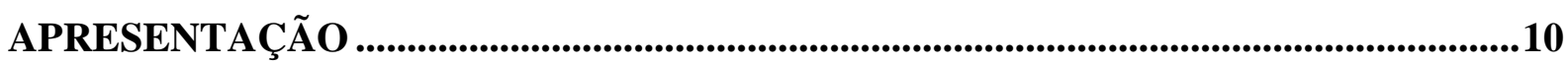

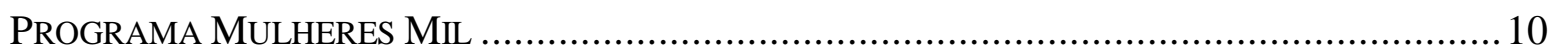

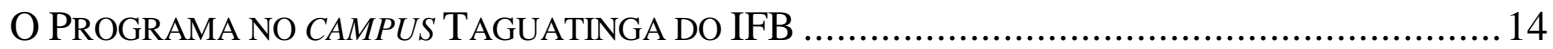

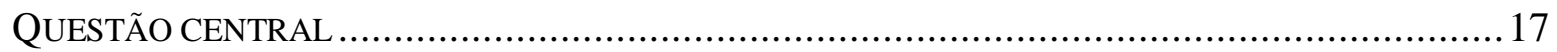

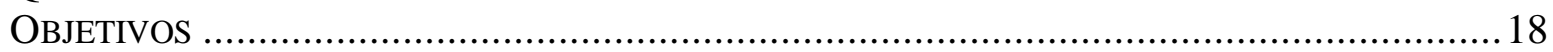

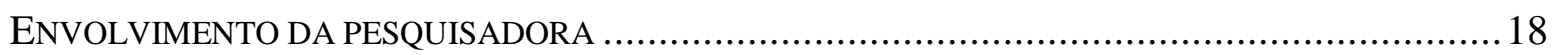

1 RELEVÂNCIA DO CAPITAL SOCIAL PARA O MULHERES MIL .......................19

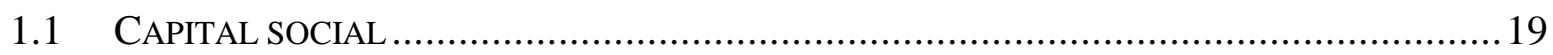

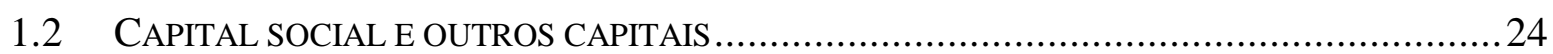

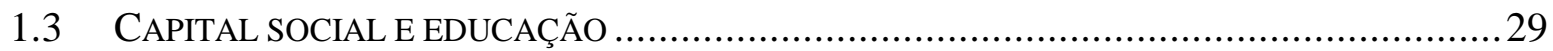

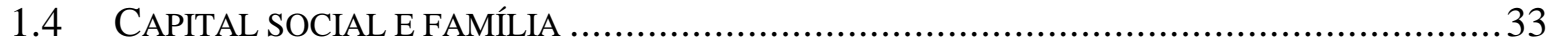

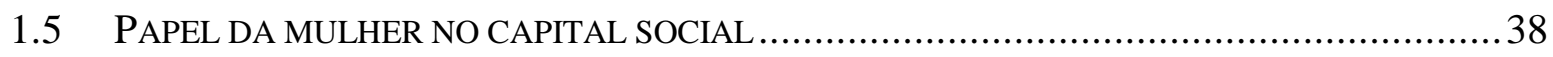

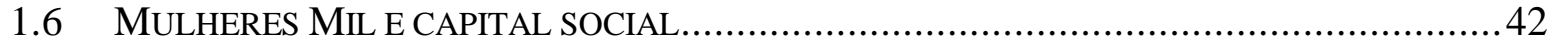

2 METODOLOGIA .........................................................................................................48

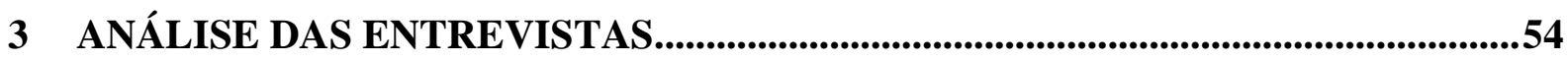

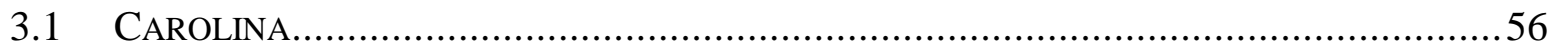

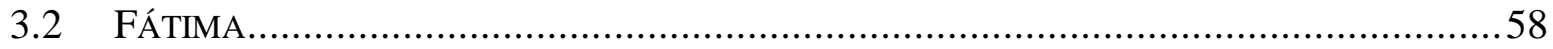

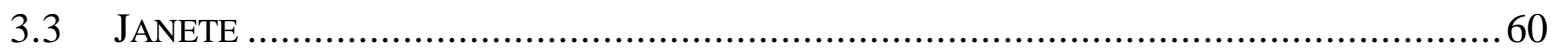

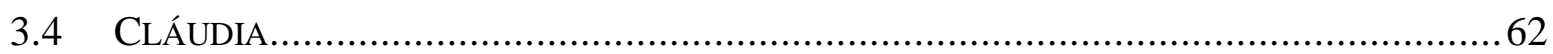

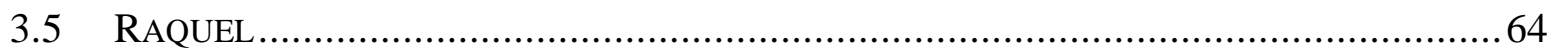

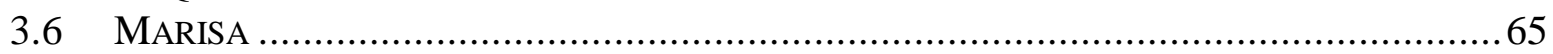

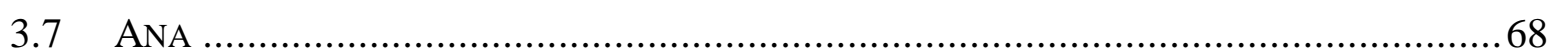

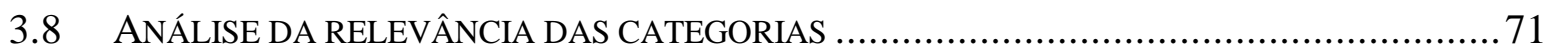

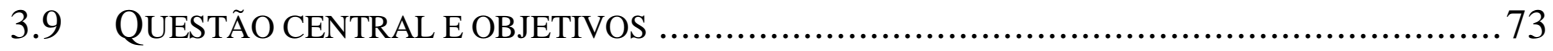

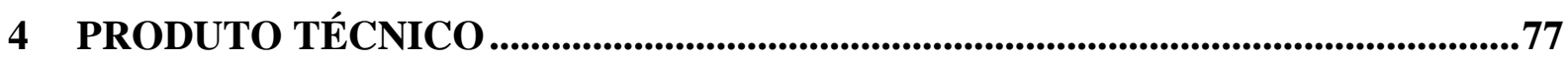

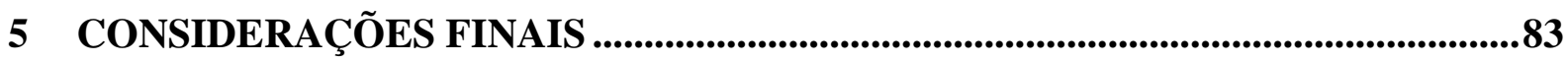

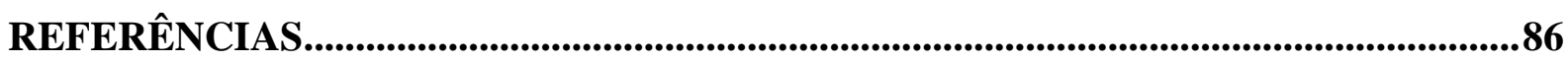

ANEXO A - Roteiro de entrevista ...............................................................................

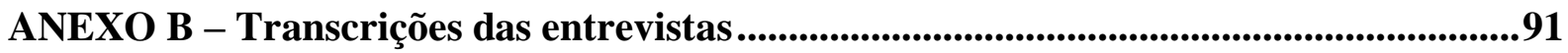

ANEXO C - Portfólio do Curso de Artesanato com Resíduos Sólidos.............................112 


\section{APRESENTAÇÃO}

\section{Programa Mulheres Mil}

O Programa Mulheres Mil - Educação, Cidadania e Desenvolvimento Sustentável é uma ação do Governo Federal que faz parte do Plano Brasil sem Miséria ${ }^{1}$. É uma política educacional e social que tem por objetivo a inserção socioeconômica de mulheres em situação de vulnerabilidade social, que se dá por meio de formação profissional e cidadã. A forma de acesso, as matrizes curriculares e os mecanismos de estímulo à permanência no Programa têm características específicas visam à autonomia, à cidadania e ao êxito das alunas na vida pessoal e profissional.

A execução do Programa é por meio da oferta de cursos FIC (Formação Inicial e Continuada) e cursos técnicos nos níveis fundamental, médio e na educação de jovens e adultos (EJA), em diversas áreas de formação profissional. Os cursos podem ser ofertados por Institutos Federais (IFs) e entidades do Sistema S.

De acordo com Brasil (2011b), a opção pelo recorte de gênero dá-se pelo crescente número de mulheres que ampliaram o seu papel na sociedade e em suas comunidades, assumindo a chefia das suas famílias, e que são responsáveis não só pelo sustento das suas residências, mas também pelo desenvolvimento cultural, social e educacional dos seus filhos e demais membros da família, fato que repercute nas futuras gerações e no desenvolvimento igualitário e justo do País.

Esta ação surgiu de uma cooperação internacional com colleges canadenses ${ }^{2}$, que possuem experiência em reconhecimento de saberes e promoção de equidade social. Iniciada como projeto piloto no ano de 2007 em 13 estados das regiões Norte e Nordeste do Brasil, foi posteriormente instituída como programa nacional, integrando o Plano Brasil Sem Miséria por

\footnotetext{
${ }^{1}$ O Plano Brasil Sem Miséria foi criado em 2011 pelo Governo Federal com o objetivo de superar a extrema pobreza até o final de 2014, atuando em três eixos: garantia de renda para alívio imediato da situação de extrema pobreza; acesso a serviços públicos, para melhorar as condições de educação, saúde e cidadania das famílias; e inclusão produtiva, para aumentar as capacidades e as oportunidades de trabalho e geração de renda entre as famílias mais pobres do campo e das cidades.

${ }^{2}$ Os Colleges of applied arts and technology ou Institutes of Technology and Advanced Learning são instituições canadenses voltadas para educação profissional com a oferta de cursos técnicos, com duração de seis meses a dois anos, e bacharelados, que podem ter de três a quatro anos de duração.
} 
meio da Portaria $n^{0}$ 1.015, de 21 de julho de 2011, do Ministério da Educação, na qual constam as seguintes diretrizes:

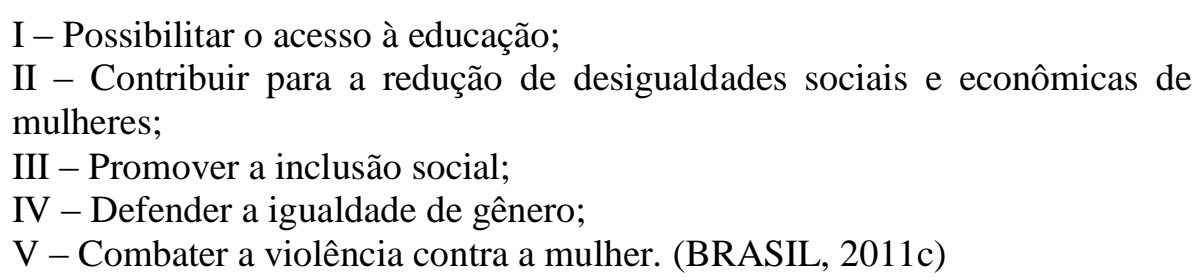

$\mathrm{Na}$ fase piloto, a metodologia adotada foi baseada na experiência canadense em reconhecimento de saberes. Posteriormente, foi adaptada à realidade brasileira, passando a se chamar Metodologia Brasileira de Acesso, Permanência e Êxito. Essa metodologia traz a sistematização de um plano educacional que possibilita a elevação da escolaridade, com cursos de formação profissional visando, também, a que essas populações desenvolvam autonomia e exerçam sua cidadania. (BRASIL, 2011b).

O Programa proporciona tratamento diferenciado e cuidadoso às mulheres das camadas mais baixas e sua elaboração considerou as especificidades deste público em situação de vulnerabilidade, marginalizado do sistema escolar tradicional por diversas razões, entre elas, a dificuldade de acesso à educação e às instituições de ensino.

De acordo com Brasil (2011b), “o acesso às instituições integrantes do Mulheres Mil passa a ser concebido como um instrumento de inclusão, dada a mudança de concepção de acesso meritocrático e seletivo para um acesso inclusivo e afirmativo" (BRASIL, 2011c). A estrutura do Programa, seu planejamento, administração e características pedagógicas são modelados para atender àquelas mulheres que acabaram se afastando do sistema escolar e que têm dificuldades em retomar os estudos, com o cuidado de tentar evitar evasões posteriormente.

As mulheres chegam ao Programa por meio de busca ativa da escola ofertante (unidades dos Institutos Federais ou do Sistema S), que apresenta o Programa e suas possibilidades a grupos formais ou informais de mulheres (grupos comunitários, Igrejas, cooperativas, associações), projetos sociais, CRAS (Centros de Referência de Assistência Social), entre outros. As mulheres são consultadas sobre os cursos profissionalizantes que gostariam de fazer, e estes são ajustados à capacidade de oferta da instituição proponente e às 
oportunidades de inserção profissional que a formação pode trazer. Para que as alunas cheguem às aulas, a instituição deve garantir o transporte.

A metodologia prevê um espaço na instituição chamado de "Escritório de Acesso", especialmente preparado para recepcionar as alunas, no qual se sintam seguras, bem acolhidas e pertencentes à escola, estimuladas a continuar os estudos. Esse local é apropriado para recebê-las em momentos que precisam desabafar ou pedir ajuda. O nível de cuidado com as alunas pode parecer excessivo, mas não é. Como já exposto, estas mulheres, em geral, não se sentem convidadas ou pertencentes a estas escolas, e, na prática, existe muita rejeição à presença de público socialmente vulnerável por parte da comunidade escolar - manifestada por técnicos, professores e alunos. O Escritório de Acesso é uma porta de entrada e um porto seguro que representa para estas alunas que aquela escola também é delas.

Além dos cuidados no acesso, alguns mecanismos são empregados para evitar evasão. Acompanhamento das estudantes, pagamento de bolsas, entrega de lanches, creche para os filhos das alunas e fornecimento de uniformes estão entre as estratégias adotadas. A escola, no Programa, tem um papel social e deve estar a par da realidade das alunas, auxiliando-as em demandas pessoais, que podem estar relacionadas com questões de saúde, emocionais, jurídicas, entre outras. Estes serviços sociais podem ser oferecidos pela própria instituição ou por parceiros. Dentre os serviços que a metodologia enfatiza estão as consultas de oftalmologista e dentista. Todos estes mecanismos auxiliam a reduzir a evasão e ampliar as chances de êxito das alunas.

A construção dos itinerários formativos deve conduzir, para além da formação profissional, ao fortalecimento da autoestima e do sentimento de inclusão, criando nelas o sentimento de pentencimento, auxiliando na permanência nos cursos:

\begin{abstract}
A concepção pedagógica do Programa baseia-se na flexibilidade, sendo, portanto, capaz de aceitar desenhos novos e instituir itinerários formativos que permitam o diálogo com os saberes não formais e com o conhecimento de mundo trazido pelas mulheres [...]. (BRASIL, 2012b, p.9).
\end{abstract}

Para Brasil (2011b), os planos educacionais devem integrar os aspectos do ensino propedêutico, a profissionalização e o domínio das tecnologias, como também a elevação de escolaridade e o resgate da autoestima. O documento também orienta que no desenho dos cursos estejam previstos projetos, oficinas e práticas em temáticas como cidadania, direitos da 
mulher, saúde, meio ambiente, relações interpessoais, inclusão digital, gênero e empreendedorismo.

Para que o Programa seja bem implementado, a comunidade escolar tem papel fundamental e deve acolher as alunas verdadeiramente. O docente que atua no Mulheres Mil deve "conhecer as estudantes (expectativas, cultura, necessidades de aprendizagens, problemas vivenciados), dominar cada vez melhor os conteúdos (saber fazer transposição didática) e refletir sobre sua prática" (BRASIL, 2012b, p.19-20).

São previstos, ainda, mecanismos para auxiliar as egressas no acesso ao mundo do trabalho, por meio de parcerias com instituições públicas e privadas e lhes apresentando abordagens que privilegiem as comunidades e as articulações de redes sociais. Este suporte, de acordo com a metodologia, se dá por meio da capacitação para a compreensão e o exercício da economia solidária, do empreendedorismo, do cooperativismo e do associativismo, como oportunidades de geração de renda e de melhor desempenho no mundo produtivo.

De acordo com Brasil (2011b), os resultados obtidos no projeto piloto demonstraram a importância de implantar políticas educacionais com recorte de gênero. Segundo as narrativas orais das alunas, detectou-se que o acesso à formação educacional e profissional contribuiu para mudanças na vida dessas mulheres em diversos aspectos, desde sua inserção no mundo do trabalho, até a melhoria nas relações familiares e no desempenho dos seus filhos na escola - visto que elas passaram a auxiliá-los e incentivá-los nos estudos. Além disso, muitas conquistaram respeito dos seus cônjuges e companheiros (reduzindo a violência doméstica), assim como assumiram o papel de multiplicadoras de conhecimentos nas suas comunidades, incentivando e mobilizando outras mulheres a seguir a mesma trajetória.

O Mulheres Mil, pela sua atuação tão abrangente - elevação de escolaridade, formação profissional, resgate da autoestima, exercício de cidadania, oferta de serviços sociais e estímulo à inserção profissional - gera efeitos diversos na vida das alunas e "mesmo que não leve à inserção no mundo do trabalho, o programa leva à uma noção de cidadania que invariavelmente leva a uma transformação social”. (BRASIL, 2011b). 


\section{O Programa no campus Taguatinga do IFB}

O campus Taguatinga do Instituto Federal de Brasília (IFB), no qual sou docente com dedicação exclusiva na área de Artesanato, Vestuário e Design de Moda, candidatou-se para a oferta do Programa no ano de 2012. De novembro de 2012 a fevereiro de 2014 assumi a coordenação local do Programa Mulheres Mil nesta escola.

Foi feita uma consulta a todos os professores do campus sobre o interesse e disponibilidade em atuar no Programa Mulheres Mil e aqueles que se mostraram disponíveis foram convidados a montar componentes curriculares integradas à formação cidadã ou profissional do curso ofertado (Artesanato com Resíduos Sólidos). Professores das áreas de História, Biologia, Administração, Informática, Design de Moda, Desenho Industrial e Engenharia Têxtil atuaram no curso. Um professor que atua na área de educação para a democracia e relações interpessoais, do Centro de Formação da Câmara dos Deputados, também ministrou aulas no curso, de forma voluntária.

Em termos profissionais, o curso habilitou as alunas a trabalharem com resíduos sólidos (materiais recicláveis descartados) transformando-os em artesanato de qualidade e de baixo custo, primando pelo bom acabamento e identificação das peças. Os principais materiais trabalhados foram jornal, garrafas pet, cascas de ovos, rolos de papel higiênico, cacos de espelho, banners, caixas de leite, embalagens de saco de cimento, resíduos têxteis e roupas desgastadas.

O plano e a execução do curso cumpriram com a maior parte das exigências dos documentos institucionais do Programa. A parte de qualificação profissional contou com oficinas práticas de artesanato com resíduos sólidos, empreendedorismo, formação de preços, cooperativismo e associativismo, e informática. Em relação à formação cidadã, contou com matérias relacionadas à inserção social das mulheres, como saúde das mulheres, gênero e direitos das mulheres, cidadania, relações interpessoais e educação para a cidadania. ${ }^{3}$

Além dos componentes ligadas à qualificação profissional, foram feitas ações no sentido de facilitar a entrada das mulheres no campo de atuação. A Secretaria de Trabalho do Governo do Distrito Federal esteve no campus para fazer as carteiras de artesão das alunas.

\footnotetext{
${ }^{3}$ No Anexo C (pág.112), encontra-se o portfólio do curso, com fotos das alunas e todas as atividades desenvolvidas.
} 
A carteira de artesão, além de isentá-las de pagar impostos sobre as peças, também permite que exponham em qualquer feira no Distrito Federal. As alunas tiveram também a oportunidade de expor e vender seus artesanatos em um stand no Fórum Social Mundial e em outros cinco eventos do IFB. Além disso, no final do ano de 2013, elas montaram uma feira com seus produtos no próprio campus.

Houve certa resistência das alunas com relação aos temas que fugiam à qualificação em artesanato. Foi um pouco difícil fazê-las compreender a importância da formação cidadã, e isto acarretou a evasão de algumas mulheres que queriam somente a qualificação profissional. Posteriormente, das que permaneceram, a maioria reconheceu que estes assuntos foram importantes na sua formação e que proporcionaram mudanças que afetaram suas vidas em diversas áreas, inclusive a profissional.

Foram promovidas algumas atividades complementares, dentre elas: curso de dança em parceria com os professores e alunos da licenciatura em Dança do campus Brasília do IFB; curso de papel artesanal reciclado e encadernação no laboratório de materiais em arte na Universidade de Brasília; visita guiada ao Congresso Nacional; visita guiada ao Centro Cultural Banco do Brasil; visita ao Salão Internacional do Artesanato; participação como expositoras no Fórum Social Mundial e em outros cinco eventos do IFB; e participação no Workshop Regional do Programa Mulheres Mil no campus Planaltina do IFB. Todas estas atividades foram muito estimulantes para as alunas, que tiveram oportunidade de conhecer lugares e realidades diferentes das delas, ampliando sua visão de mundo e bagagem cultural.

Foram montadas duas turmas de 50 alunas, com um total de 100 mulheres matriculadas. As aulas ocorriam uma vez na semana e um ou dois sábados por mês. Houve grande evasão nos dois meses iniciais (cerca de 35 alunas), e as aulas aos sábados passaram a acontecer com as duas turmas juntas. O curso foi realizado de março a dezembro de 2013, com 200 horas de duração. A extensão do curso no tempo também favoreceu a evasão, especialmente após as férias, quando alunas não retornaram para as aulas. Cerca de 50 alunas frequentaram o ano todo, mas destas, somente metade cumpriu $75 \%$ de frequência, exigência legal para aprovação e recebimento do certificado. Das 100 alunas que ingressaram, somente 25 foram certificadas $(25 \%)$.

No campus Taguatinga, as estratégicas adotadas para estimular a permanência e minimizar a evasão contaram com o pagamento de bolsas de $\mathrm{R} \$ 100,00$ por mês, 
fornecimento de lanche, transporte público gratuito, entrega de material e montagem de uma brinquedoteca para os filhos das alunas em horário de aula.

A solução de criar uma brinquedoteca para abrigar os filhos das alunas durante o período das aulas partiu da experiência do campus Taguatinga Centro, que já havia montado esta estrutura em 2012 com o mesmo objetivo. A formalização da brinquedoteca se deu por meio de um projeto de extensão, o que permitiu que cada uma das crianças fosse matriculada e contasse com as mesmas garantias de qualquer aluno do IFB, como a inclusão no Seguro Escolar.

A alta evasão pode ter resultado de um somatório de fatores. Aulas aos sábados, extensão do curso, inúmeros problemas com o Passe Livre do GDF (programa de transporte gratuito do Governo do Distrito Federal), incompreensão de algumas alunas sobre a importância da formação cidadã e demora no recebimento da primeira bolsa (que saiu somente no início de maio), são alguns aspectos que podem ter contribuído para a evasão. Somam-se a isso as dificuldades pessoais das alunas com família, trabalho, problemas emocionais, financeiros e de saúde.

Apesar de todas as dificuldades, o curso foi extremante proveitoso para aquelas que acompanharam durante o ano todo. Havia bastante heterogeneidade nas turmas, com alunas de idades e condições sociais diferentes (das alunas que entraram pelas vagas remanescentes, nem todas viviam em situação de vulnerabilidade social). Entretanto, as diferenças das mulheres se diluíram e as turmas se harmonizaram. Todas as alunas, de uma forma ou de outra, viviam alguma vulnerabilidade, de ordem social, emocional ou física. E todas aprenderam com a diversidade.

Para as alunas, o curso representou novo ânimo e disposição, e trouxe o aumento da autoestima. As componentes ligadas à formação cidadã e inserção social foram tão relevantes para elas quanto a formação profissional em artesanato de baixo custo. Uma fala recorrente era que muitas delas queriam ter dado continuidade aos estudos quando eram mais jovens, embora não tivessem tido condições. A razão apontada por algumas foram os filhos, por outras, o trabalho.

Era notório que as alunas se sentiam realizadas por estarem novamente no ambiente escolar. Elas viam no curso uma possibilidade de retornar aos estudos, uma "porta que se abriu" nas palavras de muitas delas, para, dali, prosseguir. Essa "porta aberta" fez com que valorizassem seus esforços, suas habilidades e o papel da educação em suas vidas. 


\section{Questão central}

Embora os documentos institucionais do Programa não mencionem o capital social, pela pesquisa bibliográfica realizada foram encontradas evidências de que o Mulheres Mil pode ampliar o capital social das participantes. Por outro lado, o referencial teórico permitiu evidenciar aspectos do Programa e de sua metodologia sob a ótica do capital social, e a partir deste arcabouço, analisá-lo.

Embora haja diversas concepções do que é capital social, algumas até contraditórias, a visão adotada neste trabalho está relacionada à capacidade das pessoas de se mobilizarem para o alcance de benefícios comuns, buscando a melhoria social. As redes de articulação do capital social podem estar relacionadas à mobilização nos ambientes familiar, comunitário e até a sociedade. No contexto familiar, tem destaque o papel das mulheres na movimentação e fortalecimento do capital social, dentro e fora da família.

Pelo valor do Programa Mulheres Mil - que visa dar às alunas formação cidadã, com melhores condições de inserção social e profissional - e pela importância do fortalecimento do capital social nas mulheres, figuras centrais em suas famílias e comunidades, justifica-se uma pesquisa que tenha por objetivo apontar as conexões entre o Programa Mulheres Mil e o capital social.

Para tanto, foi realizada uma pesquisa teórica sobre o capital social e suas interlocuções com outros conceitos relevantes no universo da pesquisa, momento no qual foi possível identificar aspectos do Programa Mulheres Mil que pressupõem a ampliação do capital social das mulheres, com efeitos positivos em suas vidas. Posteriormente, sete egressas do Programa realizado no campus Taguatinga ( $28 \%$ das alunas que receberam certificado) foram entrevistadas para elucidar a questão central: qual a relevância do Programa Mulheres Mil para o capital social das participantes? Para respondê-la, desdobram-se alguns objetivos. 


\section{Objetivos}

\section{Objetivo geral}

Demonstrar se o Programa Mulheres Mil realizado no campus Taguatinga do IFB teve efeitos no capital social das alunas e como influenciou suas vidas.

\section{Objetivos específicos}

- Identificar se o Programa teve efeitos no capital social das alunas e de que forma influenciou suas vidas;

- Analisar a relevância das categorias de análise para as alunas e para o Programa;

- Verificar se foram alcançados os objetivos do Programa;

- Apresentar, a partir dos resultados da pesquisa, um produto técnico com sugestões para o Programa.

\section{Envolvimento da pesquisadora}

A opção por esta pesquisa surgiu da minha vontade de compreender com mais clareza os efeitos do Programa Mulheres Mil no capital social das mulheres participantes. Durante as pesquisas bibliográficas, deparei-me com referencial teórico que demonstra que o capital social tem papel importante dentro da família, preponderantemente para as mulheres na geração, articulação e manutenção do capital social na família e fora dela.

Tendo sido coordenadora do Programa Mulheres Mil e lecionado para as alunas entrevistadas, o envolvimento pessoal com a pesquisa diz respeito aos meus posicionamentos profissional e ideológico e à relação próxima com as alunas. Muito embora essa proximidade e familiaridade possam facilitar a pesquisa por um lado, por outro, demandam cuidados e atenção para que a condução seja objetiva e os resultados não sejam tendenciosos. Essas questões, além do anonimato das alunas, foram observadas para que imparcialidade e objetividade fossem perseguidas ao longo da pesquisa. 


\section{RELEVÂNCIA DO CAPITAL SOCIAL PARA O MULHERES MIL}

\subsection{Capital social}

Capital social, nesta pesquisa, é compreendido como uma forma complexa de capital relacionado às redes de influência que um indivíduo e/ou grupo possui, que se articula com outras formas de capital, como o capital humano, o econômico e o cultural. Será trabalhado o conceito de capital social em seu sentido positivo, ou seja, em redes de articulação para o alcance de benefícios dentro da legalidade. Além da articulação do conceito de capital social com outras formas de capital, também se relacionarão os conceitos de educação, família e o papel da mulher.

Bourdieu (1979, 1980, 1986 e 2011) e Coleman (1988) nos trarão seus conceitos de capital social, as relações deste com a educação e com outras formas de capital, com abordagens diferentes, porém convergentes em alguns aspectos, como nos apontará Aquino (2000).

Silveira (2005), Alves et al (2010), Girolami (2014), e Antunes et al (2004) trazem apontamentos sobre o capital social e a educação. No presente trabalho, relacionou-se as visões de Almeida e Pereira (2000) e Demo (1999) sobre educação crítica e cidadã, pressupostos para a geração do capital social.

Nas conexões de capital social com família (e também educação), além de Bourdieu e Coleman, com destaque à centralidade da mulher e questões importantes de gênero que influenciam diretamente a compreensão do tema, as autoras Fonseca (2002), Zago (1988 e 2000), Morrow (2007) e Reay (1995 e 2004) trazem colaborações valiosas. Bilac (2006), Santos (2008) e Prá (2001) trazem contribuições significativas para a compreensão de gênero articulado com as políticas públicas e o papel do Estado.

Pelo viés do potencial democrático do capital social, de participação cidadã e revelando o papel do Estado no fortalecimento estratégico deste capital, temos Baquero (2001a e 2001b). Nas interlocuções com o tema do empoderamento, Baquero e Baquero (2007), Schmidt (2001) e Prá (2001) foram consultados.

O conceito de capital social, de acordo com Alves et al (2010, p.488), surge analogamente ao conceito de capital econômico, propiciador de mobilização e/ou aquisição de 
influências, bens e serviços. Este conceito teria sido introduzido pelos sociólogos Pierre Bourdieu, francês, e James Coleman, americano, na análise social para se referirem às vantagens culturais e sociais que indivíduos ou famílias mobilizam e que podem conduzi-los a um nível socioeconômico mais elevado. As vantagens culturais e sociais a que Alves se refere estão alojadas na capacidade de mobilização de pessoas para se chegar a um objetivo comum.

O sociólogo francês estava interessado nas maneiras com que a sociedade se reproduz, e como as classes dominantes mantêm a sua posição. As explicações de base econômica não eram suficientes para explicar por que as classes se mantinham mais ou menos estáveis. Desta forma, para o autor,

O capital social é o conjunto de recursos atuais ou potenciais que estão ligados à posse de uma rede durável de relações mais ou menos institucionalizadas de interconhecimento e de inter-reconhecimento ou, em outros termos, à vinculação a um grupo, como conjunto de agentes que não somente são dotados de propriedades comuns [...], mas também são unidos por ligações permanentes e úteis. [...]. (BOURDIEU, 2011b, p.67).

Coleman, por sua vez, tem abordagem que conduz a uma visão mais ampla e produtiva do capital social, na qual ele não é visto apenas como ações para manutenção de classes, mas observa sua utilidade objetiva para qualquer grupo, incluindo comunidades marginalizadas. Ele consegue vislumbrar que indivíduos possam operar em grupos não só visando o benefício próprio e a manutenção do status quo, como também buscando melhorias coletivas:

[...] Coleman diz que, na medida em que entre os atores sociais há interdependência, eles somente conseguem satisfazer alguns de seus interesses agindo conjuntamente. Para tanto, é preciso haver relações sociais que tornem possível a ação conjunta. Coleman chama de capital social ao conjunto das relações sociais em que um indivíduo se encontra inserido e que o ajudam a atingir objetivos que, sem tais relações, seriam inalcançáveis ou somente alcançáveis a um custo mais elevado. O capital social localiza-se não nos indivíduos, mas nas relações entre eles, e a existência de capital social aumenta os recursos à disposição dos indivíduos que encontram-se imersos em tais relações. (COLEMAN, 1990, p.300-304 apud AQUINO, 2000, p.24).

Para Coleman (1988, p.S98), ao contrário de outras formas de capital, o capital social é inerente à estrutura das relações entre atores sociais. Ele não está alojado nem nos próprios 
atores nem nas ferramentas físicas de produção. ${ }^{4} \mathrm{O}$ capital social, para este autor, não existe nos indivíduos isoladamente.

Bourdieu e Coleman divergem quanto a alguns aspectos relativos ao capital social. Bourdieu trabalha pelo viés da reprodutibilidade da sociedade; em como as relações dentro dos grupos se apoiam para manter suas posições, impedir "forasteiros" de penetrar em seus estratos sociais e obter vantagens a partir de outros capitais que cada um dos membros do grupo possui. Já Coleman defende que o capital social é, antes, um fomentador dos capitais humanos e econômico e que pode permitir melhorias sociais por meio da mobilização de grupos em busca de benefícios comuns.

Bourdieu defende que cada indivíduo possui um determinado capital social, enquanto, para Coleman, o capital social somente existe mediante as relações entre os atores sociais. Entretanto, de acordo com Aquino,

\begin{abstract}
A diferença, porém, não é tão acentuada porque Bourdieu diz que o capital social também pode ser possuído coletivamente (por exemplo, por uma família, uma nação ou uma associação). Ainda à semelhança de Coleman, para Bourdieu, a manutenção do capital social depende da contínua ativação das relações sociais a ele relacionadas. Para ambos os autores, o capital social se desvanece se não for utilizado. (AQUINO, 2000, p.25).
\end{abstract}

O que motivou estes sociólogos a desenvolver este novo conceito de capital, de acordo com Aquino (2000, p.25), foi a busca de respostas para diferentes perguntas. Coleman queria entender por que comunidades com recursos econômicos e humanos semelhantes têm capacidades diferentes de resolver seus próprios problemas. A resposta seria que as comunidades com nível mais elevado de capital social são compostas de indivíduos que confiam mais uns nos outros, facilitando a ação coletiva e permitindo um melhor aproveitamento dos recursos econômicos e humanos à sua disposição. Bourdieu, por sua vez, sempre direcionou suas pesquisas para a compreensão do sucesso e do fracasso de indivíduos. Sua pergunta seria algo como: Por que um determinado indivíduo consegue ocupar, na sociedade, uma posição que outro indivíduo sequer sonhou? A resposta estaria na quantidade dos diferentes capitais (cultural, humano, econômico, social) acumulados pelo indivíduo por herança ou por esforço pessoal.

4 Tradução livre do texto: "Unlike other forms of capital, social capital inheres in the structure of relations between actors and among actors. It is not lodged either in the actors themselves or in physical implements of production" (COLEMAN, 1988, p.S98). 
Bourdieu tem visão pouco otimista em relação ao capital social, se comparado com outros autores. Ele o vê este capital como uma das explicações para a permanência das estruturas de classe e de poder se manterem mais ou menos imóveis. As redes de relações que ele menciona oferecem recursos para as pessoas manterem ou ampliarem seus níveis de capital e se reconhecerem (e serem reconhecidas) como um grupo. De acordo com Baquero e Baquero:

[...] O termo tem sido interpretado de forma diversa, dependendo da perspectiva teórica utilizada. A própria noção de capital social ainda não é um conceito unânime, pelo menos para a maioria dos que com ele trabalham. Pelo contrário, há mais divergências do que consensos em relação ao papel que capital social tem (ou não) no fortalecimento democrático e no desenvolvimento social. Muitas vezes se enfatiza mais o que o conceito não é. Tem sido comum, por exemplo, estabelecer uma correlação entre capital social e o potencial de construção de redes de exclusão e de movimentos que podem levar à institucionalização de movimentos negativos em todos os planos (nazismo, narcotráfico, gangues, sectarismo, entre outros). (BAQUERO, M; BAQUERO, R; 2007, p.51-52)

O trecho acima e a abordagem de Bourdieu são lembretes importantes que o capital social pode ser excludente. Entretanto, ver o capital social somente como algo excludente é ignorar que este conceito é potencialmente transformador, abordagem que será adotada neste trabalho.

Baquero e Baquero (2007) afirmam que existe um ponto comum entre boa parte dos cientistas sociais e aqueles que trabalham com o conceito de capital social na atualidade. Segundo os autores, o ponto de convergência entre as diversas acepções teóricas é o de que capital social tem como "objetivo a ser alcançado a tangibilização de resultados concretos que ajudem a melhorar a qualidade de vida da comunidade e, consequentemente, individual" (BAQUERO; BAQUERO, 2007). Isto é, quando as pessoas querem melhorar as condições de vida da comunidade, coletivamente reúnem esforços com base na confiança recíproca para promover as mudanças necessárias que transformarão e melhorarão suas comunidades. Esta capacidade de mobilização, que se encontra em maior ou menor grau nas pessoas e comunidades, é o capital social.

Baquero, 2001a, reúne os pontos de convergência de diferentes postulações de capital social:

1. Todos integram as esferas política, econômica e social e se pressupõe que as relações sociais influenciam a forma como os mercados e 
Estados operam e que, por sua vez, são influenciados por esses mercados e Estados;

2. Todos convergem para a análise das relações entre atores e as formas que podem gerar relações estáveis e confiáveis entre eles, aumentando tanto eficiência individual quanto a coletiva;

3. Todos sugerem que o capital social pode ser fortalecido, mas esse processo exige uma gama de recursos de natureza diferenciada;

4. Na medida em que os bens derivados de instituições públicas não podem ser apropriados privativamente, as pessoas tendem a apoiar as relações sociais e as instituições. Sendo assim, o traço que distingue capital social de outros tipos de capital [...] é a ênfase nas vantagens que resultam para as classes historicamente excluídas. (BAQUERO, 2001a, p.33-34).

Segundo Baquero e Baquero (2007), o capital social é uma construção em nível individual, organizacional e comunitária. Quando relacionado a aspectos do sujeito, é individual; na mobilização participativa de recursos e oportunidades em determinada organização, é organizacional; e, é comunitário, quando a estrutura das mudanças sociais e a estrutura sociopolítica estão em foco.

Muito embora Baquero e Baquero (2007) afirmem que se trata de uma construção também em nível individual, o capital social não é um bem que se adquire, e, muito menos, algo que se utiliza de forma individual para usufruto próprio: sua existência e uso acontecem, somente, por meio de relações entre pessoas, de forma a gerar resultados com base em confiança recíproca:

Putnam (1996), afirma que a confiança tem papel fundamental na conceituação de Capital Social. Segundo o autor, o Capital Social diferenciase dos demais tipos (econômico, humano, físico) justamente pelo fato de que quando a variável confiança é acionada, além de gerar cooperação, gera ainda mais confiança. Por isso, o conceito de Capital Social é um bem público, enquanto os outros capitais são privados." (PUTNAM, 1996, apud SILVEIRA, 2005, p.33)

Além disso, as redes de geração e uso de capital social podem ser horizontais e verticais. Dentro de uma família, de um bairro ou comunidade, temos relações horizontais de mobilização do capital social. Quando as relações ocorrem entre instituições e comunidade, são verticais.

Partindo da insuficiência dos conceitos de capital econômico e capital humano para responder às questões sociais, o capital social e seu foco nas relações entre atores para benefícios mútuos trazem a possibilidade das interações entre Estado e sociedade atuarem no fortalecimento da democracia, das instituições, no desenvolvimento econômico e na 
participação política dos indivíduos. Especialmente em sistemas políticos instáveis, como é o caso da América Latina, Baquero (2001b), traz que o conceito de capital social assume um ponto central de análise, alertando sobre a importância de trabalhar em um sentido coletivo e em contexto horizontalizado.

[...] o resgate da importância atribuída ao cidadão, à sociedade civil e à sociedade como um todo no processo de construção democrática de um país, tem se materializado em número significativo de estudos que abordam formas de inclusão da sociedade no processo político. Há uma tendência crescente na bibliografia relevante no sentido de reconhecer que a relação Estado-sociedade implica ir além da análise dos direitos e liberdades básicas e incorporar, na sua reflexão, o papel da comunidade nesse processo. (BAQUERO, 2001a, p.25)

Neste sentido, o capital social pode ser uma ferramenta para os cidadãos fortalecerem suas redes de relações a fim de buscar a realização de objetivos comuns, dentro da própria comunidade, e atuar no fortalecimento democrático, por meio da participação e mobilização social na sociedade.

\subsection{Capital social e outros capitais}

A teoria do capital deu origem a outros conceitos de capital, como o humano, o cultural e o social. Os novos conceitos elaborados a partir do capital de Marx não buscam, via de regra, substituí-lo, e sim, complementá-lo para melhor elucidar questões relativas às dinâmicas da sociedade e da economia. O conceito de capital social não pode ser isolado de outros conceitos de capital para ser compreendido, antes deve ser articulado e contextualizado com eles:

As teorias do capital constituem-se em reinterpretações da teoria do Capital de Marx (Lin, 2001). Para Marx, o capital é investimento de recursos no mercado com expectativa de retorno; é parte do processo de produção da mais valia, apropriado pela burguesia. A teoria marxista do capital está associada com a perspectiva da divisão da sociedade em duas classes antagônicas - burguesia e proletariado. Uma primeira reinterpretação da teoria clássica do capital (marxista) foi a teoria do capital humano, cujas origens remontam a Adam Smith. Por capital humano, autores como Johnson, Schultz e Becker designaram o valor agregado ao trabalhador na forma de conhecimentos e habilidades. Esta concepção implicou numa mudança do entendimento acerca da estrutura social: o capital humano é incompatível com a ideia de uma sociedade imobilizada em duas classes antagônicas. A estrutura social passa a ser concebida como uma hierarquia 
de diversos graus de capitalistas, com elevado grau de mobilidade. Cada pessoa pode investir e adquirir capital; o trabalhador passa a ser encarado como um investidor. O núcleo das análises do capital humano é o vínculo entre educação e rendimentos. Em sentido teórico e ideológico diverso, emerge a teoria do capital cultural de Pierre Bourdieu. Alinhavado com a perspectiva marxista de sociedade, o capital cultural designa a aquisição e reprodução da cultura dominante e seus valores, sendo que a cultura dominante é imposta pelas classes dominantes ao conjunto da sociedade. As teorias do capital social erguem-se sobre essas reinterpretações da teoria marxista do capital, propondo uma compreensão da dinâmica social que confere uma maior autonomia das diversas esferas sociais ante às relações econômicas. (SCHMIDT, 2001, p.122).

De acordo com Coleman (apud Schmidt, 2001):

O capital econômico é criado transformando matéria em instrumentos que facilitam a produção; o capital humano é criado transformando pessoas, conferindo-lhes novas habilidades e capacidades; já o capital social é criado "quando as relações entre as pessoas mudam de modo a facilitar a ação". (COLEMAN, 1994, p.304, apud SCHMIDT, 2001, p.123-124)

Um dos motivos que levou Bourdieu e Coleman a fazerem reinterpretações do conceito de Marx foi compreender porque aspectos unicamente ligados ao capital econômico não explicavam um melhor ou pior desempenho escolar. Eles notaram que a relação entre origem socioeconômica, ligada ao capital econômico, e resultados educacionais, ligados aos capitais humano e cultural, não bastavam para elucidar esta questão.

De acordo com Aquino (2000, p.24-25), Coleman considera que os indivíduos podem se utilizar do capital físico - máquinas, ferramentas, instalações físicas, e do capital humano habilidades e conhecimentos pessoais - para atingir seus objetivos, mas ele, também, nos diz que, na medida em que entre os atores sociais há interdependência, eles somente conseguem satisfazer alguns de seus interesses agindo conjuntamente. Para tanto, é preciso haver relações sociais que tornem possível determinadas ações. Bourdieu nos diz que onde há mais capital social há melhor aproveitamento de capital econômico e cultural.

De acordo com Alves et al (2010, p.488-490), Bourdieu entende a sociedade como um permanente campo de luta de classes, que elaboram estratégias para manter ou melhorar sua classe social. Essas estratégias estão relacionadas com os diferentes tipos de capital, e embora o capital econômico seja a fonte de todas as outras formas de capital, o capital social tende a ser transformado em capital econômico ou em capital cultural. Já Coleman vê o capital econômico como um fator mais determinante que o capital cultural e ele diverge de Bourdieu 
na forma como os capitais se articulam. Para ele, capital econômico é um dos fatores relacionados ao contexto familiar que influenciam o desenvolvimento da criança por meio dos bens e serviços aos quais ele dá acesso. O capital social, para ele, como as outras formas de capital, é produtivo, permitindo a realização de certos fins que, na sua ausência, não seriam possíveis. Da mesma forma que o capital físico e o capital humano, o capital social não é completamente conversível em capital econômico, todavia pode ser especialmente importante para certas atividades. Essa importância é de natureza variável, podendo uma determinada forma de capital social ser valiosa (no sentido de facilitar certas ações), inútil ou mesmo prejudicial, para outras.

Em particular, Coleman destaca um efeito do capital social que é especialmente importante: a criação de capital humano na próxima geração. Este advém do capital social, sendo produzido por meio da autoconfiança e da segurança em expressar suas próprias opiniões, o que permite aos jovens se tornarem melhores alunos e assim serem mais bem sucedidos na escola e na sociedade. O capital humano emerge do capital social, porque este também se desenvolve a partir de relacionamentos, especialmente dentro da família. Como Coleman aponta:

As crianças são fortemente afetadas pelo capital humano possuído por seus pais. Mas isto pode ser irrelevante para as crianças se os pais não são uma parte importante da vida de seus filhos, se o seu capital humano é empregado exclusivamente no trabalho ou em outros lugares fora de casa. O capital social da família são as relações entre pais e filhos (e outros membros da família). Ou seja, tenham os pais grandes ou pequenas quantidades de capital humano, se este não for complementado pelo capital social incorporada nas relações familiares, torna-se irrelevante para o crescimento educacional da criança. (COLEMAN, 1988, p.S110)

Outros autores corroboram a ideia de que capital humano não é sempre convertido em capital econômico. Embora os investimentos em capital humano, em geral, sejam feitos para se obter melhores condições econômicas, ele seria, então, uma resposta efetiva para combater

\footnotetext{
${ }^{5}$ Tradução livre de: "It is of course true that children are strongly affected by the human capital possessed by their parents. But this human capital may be irrelevant to outcomes for chil-dren if parents are not an important part of their children's lives, if their human capital is employed exclusively at work or elsewhere outside the home. The social capital of the family is the relations between children and parents (and, when families include other members, relationships with them as well). That is, if the human capital possessed by parents is not complemented by social capital embodied in family relations, it is irrelevant to the child's educational growth that the parent has a great deal, or a small amount, of human capital". (COLEMAN, 1988, p.S110)
} 
as desigualdades sociais. Entretanto, a relação não é tão simples, como alertam Almeida e Pereira:

\begin{abstract}
A conclusão de diversos estudos realizados tanto por sociólogos, como por economistas, pedagogos, entre outros pesquisadores, é a de que a forte correlação positiva entre renda e educação independe do aumento de habilidade cognitiva dos estudantes, que, supostamente, é o que as escolas produzem. Assim, estaria quebrado o elo da cadeia de raciocínio da teoria do capital humano, e deflagrado o debate entre os pesquisadores acerca do que as escolas produzem (além da habilidade cognitiva) que tende a influir positivamente nos rendimentos futuros dos estudantes. (ALMEIDA; PEREIRA, 2000).
\end{abstract}

Como foi apontado anteriormente, está claro que a relação positiva entre capital humano e capital econômico nem sempre é garantida, ou seja, nem sempre o investimento em capital humano se converte em aumento de capital econômico e redução de desigualdades sociais. Falta um elemento nesta relação e o conceito de capital social pode preencher essa e outras lacunas que outros capitais deixavam, ainda que não seja possível compreender um conceito de capital separadamente dos outros, já que estão interligados. Até certo ponto, os conceitos de capital são dependentes, podendo ser conversíveis entre si, em processos complexos de se identificar:

Capital social não pode ser compreendido isoladamente de outras formas de capital, [...] que juntos constituem vantagens ou desvantagens na sociedade. Capital social é gerado por meio de processos sociais entre a família e a sociedade e é constituído de redes sociais. Capital econômico é a riqueza herdada ou gerada em interações entre o indivíduo e a economia [...]. (BOURDIEU, 1985). Além da interligação dos tipos de capital, Bourdieu prevê um processo no qual uma forma de capital pode ser transformada noutra (BOURDIEU, 1986). Por exemplo, o capital econômico pode ser convertido em capital cultural, enquanto o capital cultural pode ser traduzido em capital social. (REAY, 2004, p.58)

Baquero e Baquero (2007, p.53) corroboram a ideia de que os capitais estão interligados e são conversíveis. Ainda de acordo com os autores, se o capital social é abundante, "então tanto o mercado como a democracia prosperarão e o mercado pode, de

\footnotetext{
${ }^{6}$ Tradução livre de "[Social capital] cannot be understood in isolation from the other forms of capital, econom$i c$, symbolic and social capital, that together constitute advantage and disadvantage in society. Social capital is generated through social processes between the family and wider society and is made up of social networks. Economic capital is wealth either inherited or generated from interactions between the individual and the economy, while symbolic capital is manifested in individual prestige and personal qualities, such as authority and charisma (Bourdieu, 1985). In addition to the interconnection of the types of capital, Bourdieu envisages a process in which one form of capital can be transformed into another (Bourdieu, 1986). For example, economic capital can be converted into cultural capital, while cultural capital can be translated into social capital. [...].” (REAY, 2004, p.58)
} 
fato, incidir no desenvolvimento de uma sociabilidade que reforça as instituições democráticas" (BAQUERO; BAQUERO, 2007, p.53).

Baquero (2001a, p.20) tece sua abordagem de capital social alertando para as limitações na participação democrática da sociedade, em especial na América Latina, região na qual, mesmo que tenha havido muitos avanços sociais e tecnológicos, ainda são gritantes os problemas sociais e materiais. Ele fala da insuficiência dos mecanismos democráticos em uso, levando ao questionamento da efetividade dos atuais instrumentos de democracia como instâncias de participação, controle cidadão e direitos, que não garantem uma sociedade realmente democrática e não resolvem os problemas relativos à pobreza e à miséria. Para o autor, estes mecanismos não têm efetividade onde não há capital social suficiente para garantir participação autêntica na construção das políticas. Ou seja, existem estruturas de participação, esta é "garantida", mas sem a presença do capital social as classes mais necessitadas não conseguem acessar tais mecanismos e nem se articular suficientemente para exigir mudanças estruturais.

Este modelo de participação, de acordo com Baquero, (2001a, p.21), "tem se revelado perverso ao acentuar a exclusão social e agravar problemas estruturais que se refletem no desemprego crônico, na desconfiança e desencanto com a política e na situação de incerteza dos cidadãos com o seu futuro" (BAQUERO, 2001a, p.21). Ele aponta que essa forma de participação se revela centrada nas conquistas individuais, o que fragmenta o tecido social e enfraquece as instâncias coletivas, como a família e os grupos comunitários. Esses posicionamentos levam a avaliar a insuficiência das teorias do capital econômico e do capital humano como norteadores de políticas de Estado, modelos econômicos e sociais. Para Baquero, uma resposta à insuficiência desses capitais se daria com o fortalecimento do capital social, por meio do

investimento e uso de recursos nas relações sociais com expectativa de retorno. Os retornos, entretanto, nesta conceitualização são usufruídos pelos próprios indivíduos. [...]. É evidente, portanto, que o traço que distingue o que é o conceito de capital social de outros tipos de capital (econômico, cultural, político e organizacional) é a ênfase nas potenciais vantagens que resultam para as classes historicamente excluídas. (BAQUERO, 2001a, p.33)

O capital social, na abordagem desta pesquisa, é o fator que pode facilitar a superação de problemas sociais, proporcionando condições mais tangíveis de transformação social, inclusão e participação. $\mathrm{O}$ capital social, manifestado por meio de relações sociais com maior 
confiança e maior participação social, pode ser um facilitador para o acúmulo de capital humano e econômico, e, ainda que de forma indireta, um facilitador para a redução de desigualdades sociais. Para tanto, as políticas públicas devem trabalhar esse capital de forma positiva e efetiva, para garantir a participação das camadas excluídas no debate democrático.

\subsection{Capital social e educação}

Educação é um terreno vasto, que tem interfaces com a família, com a escola, com a sociedade, com o Estado, com a estrutura de classes e com os capitais econômico, cultural e humano. Da mesma forma, o debate do capital social com a educação também é complexo, e pode ser controverso.

Bourdieu enfatiza a reprodutibilidade da escola, desmistificando seu papel de propiciador de mobilidade social: "é provavelmente por um efeito de inércia cultural que continuamos tomando o sistema escolar como um fator de mobilidade social, [...], quando, ao contrário, tudo tende a mostrar que ele é um dos fatores mais eficazes de conservação social" (BOURDIEU, 2011a, p.41). Ainda de acordo com o autor,

As cifras sistemáticas que ainda separam, ao final do cursus escolar, os estudantes oriundos dos diferentes meios sociais devem sua forma e sua natureza ao fato de que a seleção que eles sofrem é desigualmente severa, e que as vantagens ou desvantagens sociais são convertidas progressivamente em vantagens e desvantagens escolares pelo jogo das orientações precoces, que diretamente ligadas à origem social, substituem e redobram a influência desta última. (BOURDIEU, 2011a, p.51-52)

Segundo o autor (2011c, p.74), esta definição tipicamente funcionalista das funções da educação ignora a contribuição que o sistema de ensino traz à reprodução da estrutura social. Também ignora que o rendimento escolar depende do capital cultural previamente investido pela família e que o rendimento econômico e social do certificado escolar adquirido depende do capital social - também herdado -, que pode ser colocado a seu serviço.

Conforme visto no bloco anterior, Bourdieu compreende o capital social como algo herdado, como um pertencimento anterior a um determinado grupo ou a uma determinada rede de relações, nas quais os indivíduos se reconhecem e mutuamente se aceitam para a acumulação de mais capital econômico e para a manutenção do status social. Seria, portanto, um mecanismo imobilizador das estruturas sociais. Apesar da visão de Bourdieu ser muito 
procedente, outros autores visualizam no capital social uma alternativa para a redução de desigualdades sociais e para maior participação.

Baquero (2001 apud ANTUNES et al, 2004, p.1) nos diz que o capital social pode ser incrementado pela educação, potencializando comportamentos participativos e cidadãos. $\mathrm{O}$ capital social seria o processo e o instrumento de empoderamento do cidadão que pode mudar as relações pessoais e intercâmbios sociais que gerem mais redes de cooperação e solidariedade.

De acordo com Antunes et al (2004, p.1), os debates em torno do conceito de capital social apontam para três variáveis principais que podem ser trabalhadas nas escolas para ampliar os estoques de capital social: confiança, cooperação e participação: "a confiança alimenta a previsibilidade das relações sociais e, por sua vez, gera a cooperação entre as pessoas. A cooperação, por sua vez, alimenta a confiança e a reciprocidade entre os membros das associações e incrementa a participação em associações voluntárias" (ANTUNES et al, 2004, p.1). Os autores defendem que:

Tendo em vista as características do capital social que afetam a comunidade, a educação formal e informal pode ser um laboratório de orientação para que as pessoas incorporem novas propostas de relações comunitárias para superação dos problemas de ação coletiva, bem como, pode aperfeiçoar as relações de autoridade, cooperação comunitária e participação política, advindas da confiança derivada das normas e sanções que regulam a reciprocidade e facilitam a comunicação e o fluxo de informações, bem como, ampliar as redes de empenho cívico que desenvolvem relações horizontais sustentadas nas tradições históricas e nas experiências vividas. (ANTUNES et al, 2004, p.4)

Em torno deste debate, Silveira (2005, p.38) destaca que as escolas reforçam as regras e normas sociais e, portanto, estão aptas a fomentar o capital social por meio da construção de normas e valores. Conforme a autora, os objetivos da educação cidadã, capaz de fortalecer o capital social e beneficiar o capital humano e econômico, são:

estimular a capacidade de discernimento dos cidadãos nas esferas política, econômica e social; cultivar competências cognitivas, procedimentais e associativas nas pessoas, para que elas sejam protagonistas em suas relações sociais, com o Estado e o Mercado [...]. Em suma, a educação cidadã, aspira à participação política, à vida democrática e à autonomia dos indivíduos. (SILVEIRA, 2005, p.68)

Silveira traz alguns autores que corroboram a ideia de que a formação do capital social pode ser estimulada por meio da educação. Para Schmidt (2000 apud SILVEIRA, 2005, p.58- 
59), a escola pode realizar a transmissão intencional de atitudes políticas de forma sistemática, por meio de conhecimentos vinculados ao mundo político - trabalhados e discutidos em sala de aula - e a transmissão não intencional, por meio de relações entre colegas, professores e funcionários.

Já na visão de Campbell (2003 apud SILVEIRA, 2005, p.60), a escola pode contribuir para o capital social privilegiando nas aulas e nas atividades escolares discussões relacionadas à resolução de problemas e às estratégias de ação nas comunidades mais próximas dos alunos, enfatizando o serviço comunitário voluntário. Desse modo, ao promover trabalhos desta natureza, a escola pode gerar sentimentos de confiança, cooperação e civismo entre os alunos. Por sua vez, Valdivieso, (2003 apud SILVEIRA, 2005, p.67) traz que a educação cidadã pode estimular o capital social e permitir que as pessoas integrem suas comunidades e ordens socioeconômicas de forma ativa, participando das decisões políticas e democráticas.

Da mesma forma, Baquero (2001b, p.63) corrobora com a visão de que a estrutura educacional de um país colabora para a consolidação de valores, podendo contribuir ou não para a formação de capital social. Para o autor, as sociedades com elevados índices de capital social têm os valores comunitários acima dos interesses pessoais e isso determina o avanço das redes, da democracia e da confiança, elementos necessários para o desenvolvimento democrático. Os valores comunitários podem ser reforçados ou fragilizados pelo grau de solidariedade, altruísmo, respeito e tolerância fomentados pela educação (juntamente com os meios de comunicação e as instituições).

A participação política é fruto de educação, segundo Schmidt (2001, p.119-120). O "caráter democrático" não é inato, é construído e esse pressuposto evita a armadilha de se achar que os cidadãos são indispostos e incapazes de exercerem participação política: “ $A$ ausência de mecanismos de participação na família, na escola, no local de trabalho, prejudica sensivelmente a predisposição para a participação política" (SCHMIDT, 2001, p.119-120).

A educação como fomentadora de comportamentos participativos e cidadãos vem ao encontro do que defende Demo (1999). Ele argumenta que o objetivo primeiro das escolas deveria ser a formação cidadã, com uma aprendizagem de base político-crítica, para, então, se criar mecanismos de inserção profissional. O autor defende que, antes de mais nada, a prioridade da educação deve ser o desenvolvimento humano como base e daí a importância 
decisiva de políticas públicas na área de educação para "a construção de um futuro comum mais compartilhado e digno [...]" (DEMO, 1999).

Apesar de vários autores defenderem que o fomento do capital social por meio da educação pode ser uma possibilidade de abertura para a formação de cidadãos participativos, capazes de formar redes para a realização de objetivos comuns, e um viabilizador da participação democrática, Girolami (2014, p.190), na sua pesquisa sobre jovens de baixa renda no Brasil e na Argentina, alerta que as pessoas e grupos mantêm diferentes relações com os diversos âmbitos de ação e intercâmbio em suas redes de capital social, e essas redes costumam ser muito precárias para os grupos sociais mais empobrecidos:

O capital social acumulado e as redes de relações que se derivam, facilitam a coordenação e a comunicação e ampliam a informação, tanto na busca de trabalho como nas tentativas de solução das próprias carências, constituindose um recurso estratégico. O capital social desses jovens reside e se enlaça fortemente em suas redes familiares e de amigos. Por outro lado, o problema se encontra na pouca densidade do capital social [...] que poderiam ajudá-los a superar sua atribuição à pobreza e servir-lhes de pontes para ampliar suas possibilidades ou sua informação e, com isto, modificar sua situação de marginalidade. [...]. (GIROLAMI, 2014, p.200-201)

A autora nos coloca diante de um ponto muito importante ao analisar a correlação entre capital social e educação. Ao se falar em fomento do capital social, é importante questionar que redes estão sendo trabalhadas no percurso escolar. As redes que devem ser fortalecidas e ampliadas devem ser aquelas que permitem aos cidadãos irem além de suas atuais circunstâncias materiais e objetivas. Para Girolami, (2014, p.200-201) apesar das redes originais serem de pouca densidade, a educação, os programas de estágios, como também os programas de trabalho com intermediação laboral possibilitariam ampliar as pontes e conectar os jovens com redes mais amplas.

Complementando Girolami e trazendo novamente Bourdieu, para quem o capital social é basicamente herdado, ao se falar em educação para o fortalecimento deste capital, não se deve esquecer de onde vêm os cidadãos, suas redes e grupos de origem, ou seja, seu capital social herdado. A partir deste ponto é possível pensar em estratégias de fomento à criação de capital social por meio da educação, com o objetivo de criação de empoderamento, confiança, solidariedade, fortalecimento dos valores comunitários e maior participação democrática, pressupostos para a superação de desigualdades sociais. 


\subsection{Capital social e família}

$\mathrm{Na}$ investigação sobre o capital social, é de interesse, também, o contexto das redes no interior das famílias e suas interlocuções internas e externas na geração deste capital. Dentre os aspectos no âmbito intrafamiliar, destacam-se o diálogo, a disponibilidade, o envolvimento da família e a confiança como valores que podem causar efeitos no desempenho escolar dos filhos. No âmbito extrafamiliar, ressaltam-se as relações com grupos, com a comunidade e com a escola, e o envolvimento em espaços de participação, vínculos que, também, podem ser fortalecidos a partir do contexto familiar.

Coleman (1988, p.S110) afirma que a transferência do capital humano dos pais para os filhos só é possível se houver, também, capital social disponível. Segundo o autor, é irrelevante um alto estoque de capital humano no desenvolvimento dos filhos se este não for complementado pelo capital social. Coleman diz ainda que o capital social está além do apoio familiar e, também, deve ser entendido como a mobilização da rede de apoio social no processo de crescimento educacional dos filhos.

Bourdieu (2011a, p.45) por sua vez entende que o capital social mobilizado dentro das famílias não é tão determinante. Para o autor, as crianças das camadas mais favorecidas herdam, sem esforço consciente de seus pais, saberes, "savoir-faire", gostos e um "bomgosto", de alta rentabilidade escolar. Bourdieu entende que estes valores herdados sem esforço são mais valiosos na vida escolar das crianças do que aqueles diretamente utilizáveis nas tarefas escolares, frutos da mobilização do capital social no interior das famílias. Em síntese,

\footnotetext{
enquanto Bourdieu enfatiza os conflitos e as lutas concorrenciais entre indivíduos e grupos pelos diferentes espaços de poder, Coleman destaca os meios pelos quais os diferentes grupos sociais trabalham em conjunto e as relações de reciprocidade e de confiança estabelecidas entre seus membros. Provavelmente, as diferenças existentes entre essas duas perspectivas contêm, de maneira implícita, parte das razões que tanto levam Bourdieu a relativizar o papel da família na mobilização de capital social como levam Coleman a enfatizar as relações internas à família como uma das principais fontes de mobilização desse tipo de capital.” (ALVES et al, 2010, p.491)
}

Zago (1988, p.64) alerta que a abordagem de Bourdieu está apoiada na crença da carência ou do conflito cultural para explicação das desigualdades sociais e escolares, visão que predominou nas décadas de 60 e 70. Esta orientação está calcada nas teorias da 
reprodução, em que as desigualdades sociais têm origem nas carências socioculturais das famílias populares, que não podem proporcionar estímulos suficientes e adequados ao desenvolvimento escolar. Apesar de fundamental na compreensão das desigualdades sociais, as teorias da reprodução acabaram sendo muito deterministas ao reduzir as famílias a um conjunto de variáveis econômicas e sociais, com pouco interesse sobre o que se passa em seu interior, suas ações e significados face ao universo escolar. As atividades familiares não são observadas, mas deduzidas da condição de classe a que pertencem os sujeitos. Desta forma, torna-se relevante contextualizar as famílias das camadas populares e problematizar as relações no seu interior. De acordo com a autora (2000, p.71), vários pesquisadores vêm se empenhando em avançar na compreensão da complexa relação entre família e escola e, de modo geral, nas questões relacionadas ao fracasso e também ao sucesso escolar, em diferentes meios sociais.

\begin{abstract}
Acompanhando as tendências sobre as relações família e educação, várias pesquisas têm possibilitado conhecer melhor o ambiente doméstico como espaço de socialização, no seio do qual se desenvolvem as práticas educacionais. Em épocas mais recentes, um número significativo de pesquisas têm se voltado para a compreensão dos processos escolares considerando, ao lado das condições socioeconômicas, os projetos e as práticas familiares de escolarização, entre outras dimensões (objetivas e simbólicas) da dinâmica social. Vários autores, oriundos de diferentes campos disciplinares (Sociologia, Antropologia e Psicologia Social) e que colocam em destaque os sujeitos enquanto atores sociais, forneceram contribuições sobre como se produz a exclusão do sistema de ensino e também sobre a mobilização de pais e alunos pelo prolongamento da instrução formal. (ZAGO, 1988, p.65)
\end{abstract}

Fonseca (2002, p.2) nos alerta que a constituição familiar mudou muito nas últimas décadas e que a unidade doméstica calcada na família nuclear não se manifesta com a mesma frequência de cinquenta anos atrás. O conceito de família já foi amplamente desmistificado frente à incrível diversidade de formas familiares constatadas hoje, e nos grupos populares ele está ancorado nas atividades domésticas do dia-a-dia e nas redes de ajuda mútua (2005, p.51).

[...] a proliferação de pesquisas antropológicas nas últimas décadas do século vinte mostrou que existe, no seio da modernidade, uma enorme diversidade de dinâmicas familiares. Comportamentos que divergem do modelo dito moderno se encontram não somente nos continentes exóticos (África e Ásia) e nas regiões "subdesenvolvidas", mas dentro dos países vistos como protótipos da modernidade - na Europa e nos Estados Unidos. [...] Apesar de verificarem tendências contemporâneas muito difundidas - o aumento da expectativa de vida, por exemplo, que vem modificar a relação entre gerações adultas da família, e o aumento do divórcio - pesquisadores 
concordam hoje que não existe padrão universal de evolução familiar. (FONSECA, 2002, p.3-4)

Assim sendo, para falar sobre capital social no interior das famílias, é necessário despir-se de conceitos arraigados e estereotipados do que é uma família constituída, bem como entender as famílias que estão por trás de dados estatísticos e números. Essa abordagem exige uma compreensão de que as famílias não são constituídas de uma única forma, que há múltiplas possibilidades de constituição familiar, inclusive para além dos laços de parentesco. Em se tratando de classes empobrecidas, deve-se considerar que as famílias são determinadas pelos aspectos sociais e econômicos, mas também pelos seus próprios valores e dinâmicas internos, abordagem esta que implica, segundo Zago (1988, p.65), em considerar as famílias não em termos de modelos genéricos, mas famílias concretas, socialmente situadas.

Esta abordagem questiona enunciados deterministas de que as condições socioeconômicas das famílias, além da baixa escolaridade de seus membros, criam ambientes somente desfavoráveis para a educação escolar. Zago (1988, p.70) afirma que nas classes populares, os pais, destituídos de capital econômico e material, mantêm uma relação positiva com a educação escolar, mesmo diante dos obstáculos materiais e insucessos escolares. De modo geral, a única via que estes pais podem vislumbrar como possibilidade de integração social e profissional dos filhos é a escola.

As famílias das camadas populares visualizam a importância da educação e têm planos para a vida escolar das crianças, entretanto esses planos, na maior parte, estão configurados dentro de suas realidades (em geral, limitadas) e nem sempre são levados a cabo, dadas as circunstâncias materiais. Fazendo um paralelo hipotético, enquanto a família de um adolescente da classe média exige seu diploma de bacharel, a família de um adolescente pobre exige seu diploma do ensino médio.

Voltando ao capital social, ele deve ser reforçado no interior das famílias, em especial as mais pobres. Para a consecução dos planos das famílias para a educação dos filhos, Laurens (1992, p.21 apud ZAGO, 2000, p.74) considera como elemento significativo de longevidade escolar a rede de relações sociais que, mediante certos tipos de apoio, influências ou informações, permite conhecer melhor o funcionamento do sistema de ensino.

Desta forma, ainda que as famílias das camadas populares não participem de redes e grupos exclusivistas e privilegiados, como coloca Bourdieu, ou de redes sociais de alta 
densidade, como aponta Girolami, sua capacidade de articulação, de busca e transmissão de informações (dentro e fora da família), o diálogo entre pais e filhos, a clareza do projeto escolar, podem, como coloca Coleman, proporcionar melhor desempenho e maior longevidade escolares.

Para corroborar a importância do capital social no interior das famílias, foram trazidas algumas pesquisas. Dados da investigação conduzida por Schmidt (2001, p.126-127) merecem atenção. Na pesquisa, realizada com jovens de oito cidades brasileiras no ano de 1999, constava a questão "Qual é a confiança que você deposita nas seguintes pessoas e instituições?" (SCHMIDT, 2001, p.126-127). Dentre as opções que receberam "Muita [confiança]" como resposta, a mãe, estava em primeiro lugar com $87,8 \%$ e o pai, com $73,3 \%$, em segundo, liderando as preferências de confiança dos jovens. Em terceiro lugar com "Muita [confiança]" estão os irmãos com 45,6\%, seguidos de igreja, com 38,6\%.

No que tange à confiança, atributo essencial do capital social, a família, representada pela mãe, pelo pai e pelos irmãos, são as pessoas em quem se pode confiar. Os jovens têm determinadas expectativas em relação a eles, e sabem o que podem esperar. Existe, na relação familiar, certa previsibilidade de comportamento que ajuda os jovens a depositarem, ali, sua maior confiança:

Os pais, portanto, constituem-se nos principais referenciais dos jovens no tocante à confiança. Eles, mais que ninguém, continuam representando para os jovens as pessoas em que podem acreditar e de onde esperam apoio e orientação. (SCHMIDT, 2001, p.126-127)

Alves et al (2010, p.495) analisaram os dados do Brasil no PISA ${ }^{7} 2000$ para evidenciar as relações entre capital humano, econômico e social e suas possíveis conversões. Naquele ano, os testes foram nas áreas de matemática, ciências e leitura. Os autores destacaram, dentre os aspectos avaliados, aqueles que tinham relação com o capital social: "Diálogo familiar", "Status ocupacional" e "Recursos educacionais familiares". O resultado da análise mostrou que as variáveis representaram efeito positivo no bom desempenho dos alunos brasileiros em leitura.

\footnotetext{
${ }^{7}$ O Programme for International Student Assessment (Pisa) - Programa Internacional de Avaliação de Estudantes - é uma iniciativa internacional de avaliação comparada, aplicada a estudantes na faixa dos 15 anos, idade em que se pressupõe o término da escolaridade básica obrigatória na maioria dos países. O programa é desenvolvido e coordenado pela Organização para Cooperação e Desenvolvimento Econômico (OCDE). No Brasil, o Pisa é coordenado pelo Instituto Nacional de Estudos e Pesquisas Educacionais Anísio Teixeira (Inep). Fonte: http://portal.inep.gov.br/pisa-programa-internacional-de-avaliacao-de-alunos
} 


\begin{tabular}{|c|c|c|}
\hline Tipo de capital & Variáveis & Modelo 1* \\
\hline \multirow{2}{*}{ Econômico } & Constante & 409,42 \\
\hline & Posse de bens & 9,0 \\
\hline \multirow{3}{*}{ Social } & Dialogo familiar & 9,0 \\
\hline & Status ocupacional & 9,0 \\
\hline & Recursos educacionais familiares & 11,0 \\
\hline \multirow{2}{*}{ Cultural } & Nível de escolaridade da mãe & 8,0 \\
\hline & Posse de bens culturais & 3,0 \\
\hline $\mathbf{R}$ & & 0,162 \\
\hline
\end{tabular}

Na mesma análise, as correlações entre "posse de bens" e "recursos educacionais familiares" também revelaram a importância do capital social no desempenho escolar. Os arranjos encontrados foram: "alta posse de bens/baixa posse de recursos educacionais familiares" e "baixa posse de bens/alta posse de recursos educacionais familiares":

o primeiro arranjo permite concluir que, apesar de as famílias possuírem alto capital econômico, este não é disponibilizado na forma de recursos educacionais para apoiar a escolarização dos filhos. Nesse grupo, os estudantes têm, em média, desempenho abaixo da média geral (401 e 407, respectivamente), indicando baixa mobilização de capital social familiar. Em contraste, o alto grau de mobilização de capital social identificado pelo segundo arranjo mostra que, a despeito de as famílias deterem baixo capital econômico, disponibilizam para seus filhos recursos educacionais que redundam em um desempenho acima da média geral (411 e 407, respectivamente). (ALVES et al, 2010, p.497).

Os resultados da pesquisa de Schmidt (2001) e da análise de Alves et al (2010) reforçam a importância da família no desempenho escolar por meio da mobilização do capital social, contextualizando-os com outros tipos de capital. Esses dados confirmam a importância do fortalecimento do capital social por meio da educação e da família como uma ferramenta para se obter melhores desempenhos escolares. 


\subsection{Papel da mulher no capital social}

Para dar início a este bloco, cabe o alerta de que o tema é contraditório e coloca em evidência muitos estereótipos. Encontra-se, na literatura, uma visão de família sem contextualização de gênero, que esconde os papeis de cada membro familiar na transmissão do capital social. Ademais, na literatura, em geral há o reconhecimento do papel da mulher na transmissão do capital social, mas em uma visão conservadora e irreal, na qual a mulher tem papel preponderante desde que não trabalhe e não chefie a família.

Nas interlocuções entre capital social e família, o papel das mulheres em relação à geração e fortalecimento deste capital deve ser contextualizado. Para esta pesquisa, o interesse recai, particularmente, sobre as mulheres pobres, e, para elaborar essa questão, é necessário situá-las na sociedade. De acordo com Santos (2008, p.100), ao analisar a relação entre vida profissional, maternidade e tarefas domésticas das mulheres, é importante lembrar que existem situações diferenciadas segundo a classe social. Mulheres com rendas mais baixas apresentam menor qualificação e nível educacional e, em geral, são as que, diante da maternidade, reduzem ou, até, abandonam seu trabalho, por algum tempo ou definitivamente, a fim de atender às diversas demandas da família.

Temos, ainda, que ter em vista que $38,7 \%^{8}$ das famílias brasileiras são chefiadas por mulheres e, nas classes populares, esse percentual pode chegar a $60 \%$. No contexto aqui apresentado, é relevante que se considere que as mulheres pobres, além de apresentarem dificuldades maiores de sucesso na vida escolar e de inserção no mercado de trabalho, acumulam um sem-número de funções domésticas e de cuidados com filhos, recebendo salários cerca de $30 \%$ inferiores aos dos homens ${ }^{9}$.

Como visto anteriormente, o conceito de capital social é, em geral, convergente no que diz respeito à importância da família na sua geração e articulação. Entretanto, a literatura, geralmente, ignora as questões de gênero e a relevância da mãe na criação e manutenção de redes sociais e capital social, aspectos que ficam invisíveis.

Os "pais", na literatura sobre capital social, geralmente não são diferenciados, e isso mascara que a maior parte da

\footnotetext{
${ }^{8}$ Dados do IBGE (Instituto Brasileiro de Geografia e Estatística), de 2010 (BRASIL, 2015).

${ }^{9}$ Dados de relatório das Nações Unidas, pela agência ONU Mulheres. De acordo com o relatório, em 1995 as mulheres ganhavam $38 \%$ menos do que os homens, em 2007. No entanto, essa diferença diminuiu para $29 \%$. (BRASIL, $o p$. $c i t$ ).
} 
"paternidade/maternidade" tende a ser exercida pelas mães. (BREUGEL; WARREN, 2003, apud MORROW, 2007, p.1352)

Partindo da premissa de que a maioria das mulheres pobres tem de assumir tarefas domésticas e cuidados familiares e apresenta desvantagens acadêmicas e profissionais, a definição de família como unidade (que desconsidera divisões de tarefas e responsabilidades por gênero e desconsidera as configurações familiares atuais), é, ainda mais, preocupante.

Reay aponta que a realidade familiar na literatura acadêmica vem sendo tratada de forma idealizada, obscurecendo as realidades do dia-a-dia dos cuidados com os filhos. Reside, aí, segundo a autora, uma questão ideológica que mascara um número importante de questões. Sua pesquisa sobre envolvimento parental evidenciou uma realidade social em que a maioria das atividades atribuídas à família são conduzidas por mães, porém, de forma invisível e não valorizada:

Essa contínua invisibilidade do trabalho materno é porque "nossas formas de pensar unem uma visão de mundo a um lugar que as mulheres não ocupam [referindo-se à academia]" (SMITH, 1988, p.19). Deste ponto de vantagem 'masculino', o que as mulheres fazem é invisível. O trabalho materno é visto como algo que "vem naturalmente" Enquanto ele continuar a ser visto somente como amor e carinho, a ocupação envolvida na maternidade permanecerá fora da vista. (REAY, 1995, p.339) ${ }^{10}$

Bilac (2006, p.59) aponta para a forma conservadora como a família é tratada em algumas das análises clássicas de capital social e cita como exemplo Coleman e Putnam. Para estes autores, segundo ela, algumas unidades familiares produzem mais capital social do que outras. Para Coleman, as famílias monoparentais e as nucleares de dupla renda levam a uma deficiência estrutural de capital social para as crianças, "uma vez que não têm condições de dar-lhes a devida atenção, comprometendo, assim, as relações primordiais geradas pelo nascimento de um filho, alienando a criança de direitos que esta teria dentro da família, para realocá-los fora dela" (BILAC, 2006, p.59). Para Coleman, portanto, a degeneração do capital social na família começaria, assim, na mudança da família e principalmente do papel feminino.

\footnotetext{
${ }^{10}$ Tradução livre de: "This continuing invisibility of maternal work is because 'our forms of thought put together a view of the world from a place women do not occupy' (SMITH, 1988, p.19). From this 'male' vantage point what women do is unseen. Mothering work is envisaged as something that 'comes naturally'. While it continues to be viewed as coterminous with love and caring, the work involved in mothering remains out of sight" (REAY, 1995, p.339).
} 
Bilac (2006, p.60) entende que o capital social é resultado da tecedura e do fortalecimento das redes de parentesco, de apoio mútuo e de informações, e enfatiza o papel essencial das mulheres neste processo. Segundo a autora, as mulheres são "obviamente, as encarregadas do trabalho de produção e acumulação do capital social" (BILAC, 2006, p.60) e este papel é visto pela sociedade de forma naturalizada, como se as mulheres fossem essencial e naturalmente inclinadas ao papel de cuidadoras.

O senso comum quanto ao papel das mulheres como cuidadoras, dadas ao trabalho doméstico e familiar, encobre muito do trabalho que é exercido objetivamente por elas, que demanda tempo, empenho e gastos emocionais e físicos. Este trabalho é determinado por demandas internas e externas à família.

Em contraste com os discursos predominantes que vêem a maternidade como uma relação íntima entre mãe e filho, a maternidade é mais do que uma relação pessoal e emocional, é um processo de trabalho que envolve tempo, esforço, e o uso e gestão dos recursos da família, o que ocorre no ambiente familiar, mas é moldado pelas exigências de instituições como a escola. (GRIFFITHS; SMITH, 1990, GRIFFITHS; SMITH, 1990, apud REAY, 1995, p.339) ${ }^{11}$

Como alerta Santos (2008, p.100), para as mulheres, as fronteiras entre vida profissional e vida familiar são menos delimitadas do que para os homens. Bicalho (1998, p.37-38 apud SANTOS, 2008, p.119-120) observa que os problemas enfrentados pelas mulheres são muito parecidos na maior parte das sociedades contemporâneas, tanto no campo profissional como no âmbito da vida privada. Dentre os problemas, ela destaca que não se reconhecem a maternidade e o trabalho doméstico como funções sociais e que tanto a família quanto a economia de mercado apropriam-se do trabalho da mulher. De acordo com a autora, de formas diferentes, mas interrelacionados, tanto no mundo privado quanto no público, persiste o poder masculino e a condição de classe social agrava a situação de desigualdade nas relações de gênero.

As pesquisas de Zago sobre êxito escolar nas camadas populares descortina alguns mecanismos adotados pelas famílias das camadas mais pobres, sobretudo pelas mulheres, que resultaram no alcance de sucesso escolar pelos filhos. Segundo a autora (2000, p.79), não se

11 Tradução livre de: "In contrast to prevailing discourses which view mothering as an intimate relationship between mother and child, for Dorothy Smith and her colleague Alison Griffiths, mothering is more than a personal and an emotional relationship. They describe mothering as a work process involving time, effort, and the use and management of family resources which occurs in the family setting but is shaped by the requirements of institutions such as the school" (GRIFFITHS; SMITH, 1990, SMITH \& GRIFFITHS, 1990 apud REAY, 1995, p.339). 
pode ignorar o papel central da figura da mãe no acompanhamento da escolaridade dos filhos e a pertinência de se considerar a mediação da variável gênero com outros elementos implicados nas formas de mobilização familiar e êxito escolar.

o investimento pedagógico não é a única condição capaz de interferir nos resultados escolares. Embora a mãe não acompanhe diretamente os conteúdos escolares, adota outras formas de investimento, seja no plano mais subjetivo, como a insistência constante em transmitir o valor social da educação, seja de ordem disciplinar, não autorizando a interrupção dos estudos, controlando a assiduidade e o cumprimento das tarefas de casa. (LAHIRE, 1997 apud ZAGO, 2000, p.79)

Retomando a análise dos dados da Tabela 1 (pág.37), de Alves et al (2010, p.496), verifica-se que os resultados encontrados demostram a importância da mulher no desempenho escolar dos filhos. A variável "Nível de escolaridade da mãe" teve associação positiva de cerca de 8 pontos em relação ao desempenho em leitura. O nível de escolaridade do pai não se mostrou estatisticamente significativo. Embora a variável "Nível de escolaridade da mãe" seja um indicador de capital humano, as análises dos autores também observaram as variáveis "Diálogo familiar", "Status ocupacional" e "Recursos educacionais familiares", que também apontam para a mobilização de capital social no interior da família. Já na pesquisa (pág.36) de Schmidt (2001, p.126-127), os níveis de "Muita [confiança]" na mãe superam aqueles depositados nos pais.

Também devemos considerar a atuação das mulheres no âmbito extrafamiliar, pelo seu potencial de engajamento e mobilização, reconhecendo que as "mulheres são frequentemente figuras centrais às formas de capital social que as agências de desenvolvimento e os governos estão desejosos de mobilizar para seus programas de alívio da pobreza e desenvolvimento comunitário" (MOLYNEUX, 2002 apud BILAC, 2006, p.61-62).

Bilac (2006, p.61-62) aponta que há evidências empíricas de que nos países pobres, em especial da América Latina, as mulheres das camadas de baixa renda são as que possuem os laços comunitários e de parentesco mais fortes e, frequentemente, estão engajadas em atividades de ajuda mútua, por intermédio de redes informais.

Desta forma, pode-se dizer que a "concentração histórica das mulheres no âmbito privado" (NOWOTNY, 1981, apud MORROW, 2007, p.1354) faz com que elas se tornem peças chave na geração, acúmulo e transmissão de capital social no interior das famílias, com papel relevante na educação dos filhos, ainda que de forma invisível ou pouco reconhecida. 
Caso se parta de acepções mais conservadoras sobre a mobilização do capital social, boa parte das famílias das camadas mais empobrecidas podem apresentar desvantagens na articulação do capital social em seu interior, especialmente se as mulheres forem responsáveis, sozinhas ou não, pelo sustento da casa. Entretanto, não é possível ignorar a centralidade e importância das mulheres, sobretudo mães, na mobilização do capital social dentro das famílias, ainda que estas apresentem menos recursos de tempo e escolaridade que aquelas mais abastadas. Também não se deve desconsiderar o potencial de contribuição das mulheres para capital social no âmbito extrafamiliar por meio da participação em redes formais ou informais.

\subsection{Mulheres Mil e capital social}

O Programa Mulheres Mil é uma política educacional de qualificação profissional, com viés social, voltada para a população feminina em situação de pobreza, vulnerabilidade e risco social e tem como objetivos, de acordo com Brasil (2011c): possibilitar o acesso à educação, contribuir para a redução de desigualdades sociais e econômicas de mulheres, promover a inclusão social, defender a igualdade de gênero e combater a violência contra a mulher. A justificativa para o recorte de gênero, segundo Brasil (2011b), dá-se pelo crescente número de mulheres que ampliam o seu papel na sociedade, em suas comunidades e famílias, e também pelas dificuldades de acesso à oferta de formação e qualificação profissional e cidadã que respeitem as peculiaridades e dificuldades desta parcela da população.

A formação profissional dos cursos do Programa Mulheres Mil, bem como as ações articuladas entre a instituição ofertante e o mundo do trabalho, certamente podem contribuir de maneira significativa para a inserção das mulheres no mercado. Entretanto, assume-se, neste trabalho, que o Mulheres Mil pode oferecer, com qualidade, o retorno sustentável de mulheres pobres à educação em condições compatíveis com suas realidades, possibilitandolhes adquirir autonomia, visão crítica de mundo e sentimento de dignidade e cidadania, ao mesmo tempo em que as empodera e aumenta sua autoestima, o que poderá ajuda-las a acessar cultura, lazer, e, especialmente, direitos, concordando com Brasil (2011b): “Mesmo que não leve à inserção no mundo do trabalho, o programa leva à uma noção de cidadania que invariavelmente leva a uma transformação social". (BRASIL, 2011b, grifo nosso). 
De acordo com Santos (2008, p.121), diversas ações pela equidade de gênero têm sido implementadas nos últimos anos, mas ainda há necessidade de investimentos maiores em programas de qualificação profissional e geração de renda. Prá (2001, p.184) alerta que as políticas de gênero devem potencializar as dimensões de cidadania e isso requer da gestão pública uma capacidade de inovação democrática.

Olgiati (2000, p.76 apud Santos, 2008, p.109) apresenta algumas direções de atuação do Estado para a melhoria da situação das mulheres, dentre elas: introdução de mudanças culturais; superação da segregação horizontal e vertical por meio do desenvolvimento profissional, o que também implica ações voltadas para a formação; medidas para a conciliação entre vida profissional e responsabilidades familiares e sociais, destacando-se, entre essas, propostas de maior facilidade para a participação em cursos de formação.

O Mulheres Mil se insere em uma lacuna deixada por grande parte das políticas. O Programa trabalha com o público feminino em situação de marginalidade social, dando condições de acesso e permanência das alunas nos cursos com vistas à maior participação cidadã e ampliação de oportunidades de inserção socioprofissional.

O referencial teórico trazido anteriormente enfatiza a importância do capital social, seu potencial mobilizador e de participação e o papel do Estado como fomentador da geração de capital com vistas à redução de desigualdades. Também mostrou a função essencial da educação na criação do capital social e as relações positivas deste com o desempenho escolar. Outro aspecto trazido foi a relevância do capital social na família, especialmente quando associado ao papel diferenciado que as mulheres ocupam. Esses apontamentos, quando comparados aos objetivos e diretrizes do Programa, levam ao entendimento de que este se trata de uma política educacional relevante, que estimula a geração de capital social e que pode vir a provocar transformações significativas na vida das alunas e daqueles que a ela estão ligados, dentro e fora da família.

De acordo com Brasil (2012b, p.4), o Programa promove o crescimento humano das alunas, o que aumenta a possibilidade de que contribuam com a governança de suas comunidades, na medida em que se transformam em cidadãs, social e economicamente emancipadas. Esse crescimento humano incrementa o capital social e potencializa comportamentos participativos e cidadãos.

Para Hofling (2001, p.40), a formação cidadã é um dos aspectos essenciais que as políticas educacionais devem trabalhar, especialmente em sociedades tão desiguais como a 
brasileira. A educação, para a autora, deve desempenhar importante papel, ao mesmo tempo em relação à democratização da estrutura estabelecida e à formação do cidadão, do sujeito em termos mais significativos do que torná-lo "competitivo frente à ordem mundial globalizada" (HOFLING, 2001, p.40).

Deve-se considerar, também, que a formação no Programa Mulheres Mil proporciona às mulheres retomarem os estudos em um ambiente acolhedor e cuidadoso, em uma perspectiva de construção de cidadania e autoestima. Estes aspectos podem fazer com que se sintam motivadas a seguir adiante e a continuarem estudando. O fortalecimento de aspectos subjetivos das mulheres pode ser o fator decisivo para que elas tenham mais chances de serem incluídas profissionalmente com dignidade.

Nos currículos dos cursos ofertados no âmbito do Programa, temas transversais ligados a cidadania, saúde feminina, direitos das mulheres, relações interpessoais, gênero, associativismo, cooperativismo, economia solidária e democracia são trabalhados de forma crítica por meio de técnicas participativas que valorizam a trajetória e a história de cada uma. As alunas são estimuladas a analisar suas realidades dentro do contexto maior, observando os condicionantes que as levaram a seguir determinadas trajetórias de vida. Eles também aprendem a olhar para si mesmas e se autoanalisarem, valorizando suas trajetórias pessoais. Conforme Silvia Yannoulas (2001, p.83 apud PRÁ, 2001, p.182), este tipo de abordagem configura-se em uma educação para "o exercício legítimo do poder" (YANNOULAS, 2001, p.83 apud PRÁ, 2001, p.182).

Merece destaque o "mapa da vida", instrumento pedagógico que é aplicado no primeiro e último dias de aula. Trata-se de uma atividade na qual as mulheres expressam, de forma livre (por meio de desenho, escrita, colagem, pintura), seu passado, presente e futuro, em três campos diferentes de um mesmo papel. A partir dessa representação, as alunas são motivadas a compartilhar suas histórias.

[O mapa da vida] é uma ferramenta no processo de construção do Programa Mulheres Mil e objetiva criar oportunidade e ambiente para a troca de experiências de vida das mulheres, para que elas possam ser compartilhadas e então devidamente registradas, validadas e valorizadas. (BRASIL, 2012b, p.13-14)

O mapa da vida é uma ferramenta de empoderamento que possibilita a valorização das mulheres enquanto protagonistas de sua própria história, colocando-as em uma posição de expectadora de suas vidas, permitindo que avaliem suas trajetórias. É muito gratificante 
comparar os mapas da vida elaborados no início e no fim do curso, e verificar que a forma de enxergar passado e presente e as projeções para o futuro, em geral, tornam-se mais otimistas. A nova maneira como narram as histórias revela mulheres empoderadas, mais seguras, mais respeitosas consigo mesmas, conscientes de seu próprio valor e força; verdadeiras heroínas do cotidiano comum.

A condução do Programa promove o empoderamento, um conceito complementar ao capital social. O termo vem do inglês empowerment, que significa dar poder, dar autoridade, tornar apto e representa a capacidade de se tomar decisões em benefício próprio ou em benefício da sociedade. Esta capacidade está fortemente associada à autoconfiança a ao protagonismo social. O termo tem sido aplicado pelo viés de gênero, e empoderamento das mulheres refere-se a reforçar as competências sociais, econômicas e educacionais das mulheres com vistas à transformação da sociedade, para que tenham direitos iguais.

O empoderamento tem sido apontado como um fator que auxilia na transformação da sociedade, e desta forma, sua falta seria, conforme Baquero e Baquero (2007, p.57), reflexo de uma democracia que não estimula a participação do cidadão. De acordo com os autores (ibid., p.54-55), este conceito, pela sua complexidade, tem sido mais definido pela sua falta do que pela sua presença. A ausência refere-se "à alienação, impotência e desamparo". Em sentido positivo, ele seria o processo de aquisição de controle sobre questões de interesse por pessoas, organizações e comunidades, nas dimensões individual, organizacional e comunitária. O empoderamento seria um aspecto determinante na manutenção dos efeitos do capital social, com grande potencial, especialmente no caso brasileiro, pelo legado histórico e pelas normas internalizadas de desvalorização das instituições políticas e dos políticos. Nesse sentido, os autores (ibid., p.49) afirmam que "embora capital social seja essencial, não é condição suficiente para o desenvolvimento numa perspectiva social, colocando a questão do empoderamento como elemento fundamental nesta equação" (BAQUERO; BAQUERO, 2007, p.49).

Prá (2001, p.185) reforça a importância do empoderamento associado ao capital social, e afirma que na articulação entre Estado e sociedade reside o ponto de convergência entre os dois conceitos. Para a autora, o empoderamento pode funcionar como um dos mecanismos a permitir a geração de capital social e o exercício da cidadania substantiva, cabendo às políticas públicas a função de catalisar este processo, como é o caso do Programa Mulheres Mil. 
Desta forma, o Mulheres Mil se insere em um contexto de política pública inovadora por trabalhar com público e formato diferenciados, e apresenta grande potencial de fortalecimento e criação de capital social, além de empoderamento. Entretanto, cabem, aqui, algumas ressalvas pertinentes ao Programa.

Como dito no início deste bloco, não se deve colocar no Programa a responsabilidade de garantir inserção profissional às mulheres. O Mulheres Mil pode contribuir de maneira significativa para que as participantes possam acessar o mundo do trabalho, a questão da inserção profissional está relacionada à qualificação e a teoria do capital humano não é um equívoco total, também existe relação positiva entre educação e trabalho. Entretanto, a entrada no mundo do trabalho também está relacionada com diversos outros aspectos estruturais e conjunturais, e não dá para atribuir à educação e/ou aos programas educacionais (como o Programa Mulheres Mil) a responsabilidade destas mulheres terem êxito profissional.

Tampouco deve-se entender que o Programa, se não for bem-sucedido na inserção profissional das alunas, fracassou. Seu grande mérito é fornecer educação de qualidade capaz de transformar as alunas em cidadãs, críticas, capazes de analisarem suas vidas e condicionantes, e, a partir daí, serem protagonistas de suas vidas. Isso, claro, não significa que o Programa não deva empenhar-se em buscar alternativas de entrada no mundo do trabalho, parcerias, prospectar empregadores, fomentar a economia solidária, entre outros.

Por outro lado, as políticas de geração de capital social não podem estimular a perpetuação do trabalho feminino precarizado ou não remunerado, como voluntárias ou inclinadas naturalmente aos trabalhos que envolvem cuidados e mobilização social. Tampouco se deve estimular o capital social como uma forma de responsabilizar as mulheres pela ausência do Estado, pela falta de mobilização da comunidade, ou pelo sucesso ou fracasso escolar (pela ausência do capital social na família). Ou ainda, desresponsabilizar os pais e outros responsáveis pela educação das crianças e jovens.

O capital social tem que ser uma ferramenta de empoderamento, transformação e liberdade. Há que se cuidar para que as políticas de fomento ao capital social, especialmente aquelas voltadas para as mulheres, não tenham o efeito oposto ao esperado:

[O capital social é] Considerado por uns como um conceito de vanguarda que busca fugir do economicismo na explicação das ações sociais, celebrado pelos seguidores da "Terceira Via" e do "Novo Trabalhismo", por outros é extremamente criticado, exatamente porque atribuir-lhe demasiada importância pode contribuir para ocultar ou justificar a ausência, ou a ineficiência, das políticas públicas e responsabilizar os pobres por sua 
pobreza. No que diz respeito à análise da família, o conceito de capital social será de pequeno valor heurístico se não conseguir lidar com a profunda desigualdade entre homens e mulheres, em sua produção e sua acumulação. (BILAC, 2006, p.63)

Como aponta Molyneux (2002 apud Bilac, 2006, p.61-62), o reconhecimento da contribuição feminina ao tecido social, mesmo por parte das organizações voltadas ao desenvolvimento comunitário, ajudou a criar uma série de expectativas sobre elas que têm alguns efeitos perversos: em primeiro lugar, a naturalização da relação mulher-cuidados tornam-nas alvos preferidos do recrutamento de trabalho voluntário, isto é, trabalho não remunerado, considerado uma extensão de suas responsabilidades para com a família e a comunidade. Em segundo lugar, é inegável que a mobilização das redes de parentesco, de vizinhança e outras, operadas, fundamentalmente, por mulheres (em resposta ao empobrecimento e deterioração das condições de vida resultantes das políticas de ajuste estrutural), desempenham papel preponderante na sobrevivência das famílias. Porém, por si só, essa mobilização não substitui políticas macroeconômicas, nem recursos.

Schmidt (2001, p.124), traz os autores Evans e Fox, que seguem uma linha semelhante, enfatizando a força do Estado e das instituições políticas na potencialização ou aniquilação do capital social de uma sociedade, sendo que a aglutinação ou dispersão do capital social é resultado da atuação institucional. Evans vai além ao sugerir que o Estado deixe de ser um ente regulador da interação social para ser um mobilizador político de capital social. Na articulação de Estado e sociedade, a educação ocupa privilegiado espaço institucional, e pode ser o fator decisivo na criação ou destruição do potencial mobilizador da sociedade. 


\section{METODOLOGIA}

A pesquisa aqui proposta se insere no campo da educação, tendo a realidade como ponto de partida, dela para a sociedade e seus representantes, articulados com o objeto de estudo. Interessa, aqui, evidenciar como a dinâmica social, as características históricas e conjunturais e como as relações entre pessoas e instituições se moldam e se (re)definem de forma dinâmica, em um movimento que nunca termina. $\mathrm{O}$ resultado desta pesquisa pretende demonstrar e elucidar a relação entre a política educacional Programa Mulheres Mil e seus efeitos no capital social das participantes. De acordo com Gamboa (2006), nas ciências sociais e na educação, o objeto é a realidade. A realidade comum entre sujeitos os desafia para que seja conhecida e transformada e serve como elemento mediador entre eles, em uma relação dialógica.

Ele levanta algumas questões relacionadas com as atitudes, posturas e compromissos do pesquisador durante o percurso de construção do conhecimento sobre a educação, considerando que sua problemática, por ser social, política e ideológica, não é neutra, nem está livre de conotações valorativas, sendo, na verdade, o oposto:

Pelo contrário, a problemática educacional está carregada de elementos axiológicos, de concepções filosóficas de homem, sociedade, e visões de mundo, que a transformam num campo de intermináveis controvérsias e que exige dos profissionais que a ela se dedicam, uma postura ou uma atitude comprometida, a favor ou não dos valores e das decisões que estão em jogo nessa complexa problemática da educação atual. (GAMBOA, 2006)

Apesar do inescapável comprometimento ideológico, nesta pesquisa o empirismo norteia as práticas metodológicas, desde a construção dos instrumentos de pesquisa, sua aplicação e até a análise de dados, de forma que os resultados surjam das evidências encontradas na pesquisa, à luz do referencial teórico consultado, deixando os achismos, as especulações, as opiniões previamente concebidas sobre o assunto e o senso comum afastados do universo da pesquisa.

O campo social no qual se insere faz com que a pesquisa seja, necessariamente, uma investigação de abordagem qualitativa, ainda que se optasse, porventura, por procedimentos quantitativos. A investigação sobre os efeitos do Programa Mulheres Mil na vida de sete alunas egressas do campus Taguatinga aprofundará questões pessoais, como sentimentos, 
percepções, crenças e valores que não podem ser reduzidas ou interpretadas por meio de números.

Abaixo são listadas algumas características da abordagem qualitativa relacionadas por Creswell (2010, p.208) e que foram observadas na pesquisa:

- Ambiente natural: seis entrevistas foram conduzidas no campus Taguatinga do IFB, local onde as alunas frequentaram as aulas do Programa, ambiente conhecido por elas e associado ao tema da pesquisa. Somente uma das entrevistas ocorreu no centro comunitário da área residencial de uma das alunas, no Paranoá, (que, assim como Taguatinga, é uma região administrativa de Brasília);

- Múltiplas fontes de dados: partiu-se de dados coletados pelos instrumentos de pesquisa, de documentos institucionais e da pesquisa bibliográfica para a realização da análise;

- Significados dos participantes: foram observados os significados que os participantes dão ao problema ou questão, e não o significado que a pesquisadora ou os autores da literatura atribuem a ele;

- Projeto emergente: havia um plano metodológico a ser percorrido, mas ele não ficou fixo. Durante a execução de algumas entrevistas, algumas perguntas surgiram para melhor compreensão das entrevistas. Também houve mudanças nas categorias preliminares de análise. Estas alterações foram importantes para trazer novas informações e maior objetividade à pesquisa.

O instrumento metodológico escolhido para a investigação foi a entrevista. Ela consiste em uma técnica que permite interação bastante próxima do pesquisador com os interlocutores, em uma abordagem "cara a cara" na qual é possível absorver o conteúdo fundamental das falas, mas também outros elementos, igualmente importantes e ricos em conteúdo, como por exemplo, a linguagem corporal, as entonações de voz e as expressões faciais.

De acordo com Duarte (2004), entrevistas são fundamentais no mapeamento de práticas, crenças, valores e sistemas classificatórios de universos sociais específicos e permitem ao pesquisador, quando bem conduzidas, coletar indícios dos modos como cada um daqueles sujeitos percebe e significa sua realidade, além de levantar informações consistentes 
que lhe permitam descrever e compreender a lógica que preside as relações que se estabelecem no interior daquele grupo ou situação. Segundo a autora, este tipo de mergulho é mais difícil de se obter com outros instrumentos, e, para além de corroborar ou contradizer teorias, as falas dos interlocutores é plena de significados, valores e consistência.

O momento da entrevista também é uma oportunidade para o entrevistado perceber sua realidade, sua ligação com o mundo, com a sociedade e com as pessoas, podendo, então, refletir sobre suas próprias experiências. Pesquisador e sujeitos da pesquisa ganham com este método de coleta de dados.

No caso das alunas do Programa Mulheres Mil, a ocasião das entrevistas pode ter representado a elas um reforço positivo em suas convicções na medida em que suas opiniões e percepções foram legitimadas pela oportunidade que tiveram de se expressar. Neste momento, elas talvez tenham percebido aspectos que não perceberam antes, seja pela capacidade que a fala permite, de articular ideias, seja por perguntas que levam a novas análises.

A utilização de entrevistas requer cuidados metodológicos e práticos que não podem ser subestimados. A tarefa de entrevistar é complexa e demanda atenção. O roteiro semiestruturado foi construído de forma a não limitar reflexões e a acomodar caminhos interessantes que pudessem surgir. Os questionamentos que constam do roteiro foram apoiados em teorias e na questão central deste projeto. A extensão não foi longa, a ponto de se tornar enfadonha e propiciar divagações e perda de foco, e nem curta, o que limitaria a profundidade que o tema merece, e foram conduzidas no tempo médio de vinte minutos.

O universo de sete alunas entrevistadas corresponde a $28 \%$ (25 alunas) das que finalizaram o curso e receberam certificado, e cerca de 14\% (50 alunas) do total que permaneceu frequentando as aulas, incluindo aquelas que não foram certificadas por excesso de faltas.

Minayo (1992, apud Deslandes, 1994, p.43), Creswell (2010, p.212) e Duarte (2002, p.141) concordam que, na abordagem qualitativa, uma amostra relevante não se apoia na quantidade de interlocutores selecionados para os procedimentos. A seleção intencional se alicerça na escolha de entrevistados que melhor elucidarão a questão central da pesquisa, ou seja, que possibilita, ao problema, sua melhor compreensão. Duarte nos diz que a definição de critérios segundo os quais serão selecionados os sujeitos interfere diretamente na qualidade das informações a partir das quais será possível construir a análise. Assim sendo, por ser uma pesquisa qualitativa, houve uma seleção intencional de participantes, ou seja, mais do que 
quantidade de entrevistadas ou escolha aleatória, a escolha dos sujeitos se deu pela sua representatividade no contexto da pesquisa e porque puderam elucidar as relações ocultas da questão central da investigação.

Tendo em vista os cuidados metodológicos e os objetivos da pesquisa, as perguntas do roteiro semiestruturado desta pesquisa (Anexo A, pág.89) foram elaboradas, principalmente, com o objetivo de comparar a fase anterior à participação no Programa e a posterior, com o propósito de evidenciar se houve mudanças relativas à aquisição de capital social pelas mulheres e os efeitos da participação no Programa em suas vidas. Para a definição das perguntas, também foram consideradas as categorias preliminares definidas com base na fundamentação teórica sobre o tema. Essas classificações agrupam evidências que se assemelham conceitualmente, ainda que apresentem diferenças entre si, norteando o processo de análise. Outro objetivo do roteiro de perguntas foi evidenciar os aspectos positivos, negativos e as melhorias necessárias para o Programa.

As categorias preliminares foram definidas de acordo com o referencial teórico consultado, a saber: confiança; participação (cooperação) e cidadania; relações familiares; envolvimento com a educação dos filhos; e empoderamento. A partir da análise das entrevistas e do aprofundamento do referencial teórico, houve mudança nas categorias finais.

Como se observou no referencial teórico, a confiança é um dos aspectos centrais do capital social, pois reforça os vínculos de reciprocidade das redes e grupos sociais. Participação (cooperação) e cidadania dizem respeito à atuação em grupos de diversos tipos, de forma cooperativa, quando se tratam de grupos comunitários (igrejas, grupos esportivos, cooperativas, associações), em instâncias de participação democrática (conselhos, conferências, administrações locais) ou na forma de acesso a cultura e lazer. Relações familiares é outro aspecto do capital social que tem relação com o fortalecimento das redes dentro das famílias e a partir delas. Envolvimento com a educação dos filhos era a categoria para desvendar se a participação das mulheres na educação dos filhos havia sido alterada após o Programa. Empoderamento é um aspecto com forte associação com o capital social e que pode ser determinante na mobilização deste capital.

A partir da análise das falas, percebeu-se que algumas categorias se sobrepunham, e outras se mostraram irrelevantes. Foram mantidas: empoderamento; relações familiares; e participação e cidadania. Foram excluídas a categoria envolvimento com a educação dos 
filhos (pois já estava dentro da abrangência de relações familiares); e confiança (que ficou dentro de relações sociais). Foi estabelecida uma nova categoria: relações sociais.

As categorias preliminares eram:

- Confiança;

- Participação (cooperação) e cidadania;

- Relações familiares;

- Envolvimento com a educação dos filhos;

- Empoderamento.

As categorias definitivas são:

- Empoderamento (autonomia, consciência de gênero, melhora da autoestima, capacidade de realizar);

- Relações familiares (relações com companheiros, filhos e parentes; confiança na família; envolvimento com a educação dos filhos);

- Relações sociais (melhoria e/ou ampliação das relações sociais; maior confiança nas pessoas);

- Participação e cidadania (envolvimento em grupos formais ou informais, participação em instâncias de debate e decisão).

A análise de dados teve três finalidades complementares, conforme Minayo (1992 apud GOMES, 1994, p.69): "estabelecer uma compreensão dos dados coletados, confirmar ou não os pressupostos da pesquisa elou responder às questões formuladas, e ampliar o conhecimento sobre o assunto pesquisado, articulando-o ao contexto cultural da qual faz parte" (MINAYO, 1992 apud GOMES, 1994, p.69).

As entrevistas foram gravadas e os áudios foram transcritos. Após a transcrição, houve conferência, momento no qual se ouve a entrevista gravada e se lê o texto transcrito para conferir sua fidedignidade. Uma versão editada das transcrições foi elaborada e se encontra no Anexo B (pág.91). O propósito da edição das entrevistas foi essencialmente excluir respostas obtidas por meio de perguntas mal formuladas e falas fora do contexto da pesquisa. Esta edição, contudo, manteve expressões e erros de português das entrevistadas. A opção pela não correção teve por objetivo aproximar o leitor do universo das participantes da pesquisa. 
A fase de análise ocorreu após a edição das transcrições e foi realizada de forma cuidadosa, demandando trabalho atento e árduo para evitar que aspectos essenciais na busca de evidências escapassem. Seguindo as orientações de Duarte (2004, p.221), a etapa inicial foi artesanal, demandou trabalho de fragmentação e agrupamento do material, a partir das categorias, chegando a pequenas unidades de sentido que foram, então, articuladas entre si de forma a trazer as evidências necessárias para confirmar, ou não, a questão central.

De posse de todo o material organizado e classificado em categorias, seguiu-se para o aprofundamento analítico em busca de sentidos, evidências, novas categorias, explicações e associações aparentemente desconexas. Este momento foi conduzido pelo arcabouço teórico, que norteou o processo até a elucidação do problema da pesquisa, confirmando, ou não, os pressupostos, e levando a novas questões, como se verá mais adiante.

Para finalizar, de acordo com Kerlinger (1979, p.17), “nossos sistemas de crenças religiosas, políticas, econômicas, educacionais - são sem dúvida, poderosos e frequentemente guiam nosso comportamento, não a evidência" (KERLINGER, 1979, p.17). Apesar do envolvimento da pesquisadora com o universo pesquisado e com os sujeitos da pesquisa, o que poderia levar a distorções ou à tentativa de se ver aquilo que se quer enxergar, houve grande cuidado em se manter a objetividade e o empirismo no processo de investigação. 


\section{ANÁLISE DAS ENTREVISTAS}

A análise das entrevistas iniciou com as transcrições e suas revisões. Posteriormente, as transcrições foram editadas de maneira que apenas o conteúdo relevante para o tema fosse destacado, com cuidado e atenção, para que as evidências não escapassem. Após a edição das entrevistas, as falas mais significativas foram agrupadas nas categorias de sentido, e somente então a análise, propriamente dita, foi iniciada.

A análise foi conduzida de duas formas. Primeiramente, foi feito um registro por aluna, como uma narrativa da história e percepções delas, de forma a evidenciar o conjunto de expressões, sentimentos e mudanças de cada uma por categoria de análise. Depois, foram elaborados dois quadros e um gráfico que mostram a relevância de cada aspecto considerado na vida das participantes, mostrando a influência do Programa Mulheres Mil do campus Taguatinga nas categorias de análise do capital social. Para esta análise também foi importante analisar as categorias pouco contempladas pelas falas das mulheres, que se revelaram aspectos a serem melhorados no Programa.

Conforme destacado na metodologia, houve evolução nas categorias preliminares de análise apresentadas no momento da qualificação desta pesquisa. Algumas foram excluídas, outras agrupadas, e algumas foram definidas durante a análise. As categorias finais refletem com maior exatidão, o conteúdo das falas e comportam melhor o seu significado. São elas:

- Empoderamento (autonomia, consciência de gênero, melhora da autoestima, capacidade de realizar);

- Relações familiares (relações com companheiros, filhos e parentes; confiança na família; envolvimento com a educação dos filhos);

- Relações sociais (melhoria e/ou ampliação das relações sociais; maior confiança nas pessoas);

- Participação e cidadania (envolvimento em grupos formais ou informais, participação em instâncias de debate e decisão).

O perfil das alunas entrevistadas é bastante heterogêneo e revela idade, escolaridade, número de filhos, situação conjugal, moradia e ocupação diversos, contemplando falas de diferentes realidades no universo de participantes do Programa. Este perfil procurou representar a heterogeneidade que se observou no curso e está detalhado nos quadros abaixo. 


\begin{tabular}{|l|l|l|l|l|l|l|l|}
\hline Quadro 1 - Perfil das entrevistadas & 12 \\
\hline Aluna & $\begin{array}{l}\text { Ida- } \\
\text { de }\end{array}$ & $\begin{array}{l}\text { Ocupa- } \\
\text { ção }\end{array}$ & Escolaridade & $\begin{array}{l}\text { Situação } \\
\text { conjugal }\end{array}$ & $\begin{array}{l}\text { Residên- } \\
\text { cia }\end{array}$ & $\begin{array}{l}\text { Pessoas } \\
\text { que re- } \\
\text { sidem }\end{array}$ & $\begin{array}{l}\text { Local da en- } \\
\text { trevista }\end{array}$ \\
\hline Carolina & 26 & $\begin{array}{l}\text { Desem- } \\
\text { pregada }\end{array}$ & $\begin{array}{l}\text { Ensino médio } \\
\text { completo }\end{array}$ & Casada & Própria & 4 & $\begin{array}{l}\text { Centro Co- } \\
\text { munitário } \\
\text { próximo à re- } \\
\text { sidência da } \\
\text { entrevistada }\end{array}$ \\
\hline Fátima & 54 & Artesã & $\begin{array}{l}5^{\circ} \text { ano do fun- } \\
\text { damental }\end{array}$ & Casada & Própria & 3 & $\begin{array}{l}\text { IFB } \text { campus } \\
\text { Taguatinga }\end{array}$ \\
\hline Janete & 56 & Artesã & $\begin{array}{l}5^{\circ} \text { ano do fun- } \\
\text { damental }\end{array}$ & Casada & Própria & 3 & $\begin{array}{l}\text { IFB campus } \\
\text { Taguatinga }\end{array}$ \\
\hline Cláudia & 31 & $\begin{array}{l}\text { Autô- } \\
\text { noma }\end{array}$ & $\begin{array}{l}\text { Ensino médio } \\
\text { completo }\end{array}$ & Solteira & Alugada & 1 & $\begin{array}{l}\text { IFB campus } \\
\text { Taguatinga }\end{array}$ \\
\hline Raquel & 35 & $\begin{array}{l}\text { Dona de } \\
\text { casa }\end{array}$ & $\begin{array}{l}\text { Fundamental } \\
\text { completo }\end{array}$ & $\begin{array}{l}\text { União está- } \\
\text { vel }\end{array}$ & Alugada & 4 & $\begin{array}{l}\text { IFB } \text { campus } \\
\text { Taguatinga }\end{array}$ \\
\hline Marisa & 59 & $\begin{array}{l}\text { Perita } \\
\text { socioe- } \\
\text { conômi- } \\
\text { ca }\end{array}$ & $\begin{array}{l}\text { Superior com- } \\
\text { pleto }\end{array}$ & Casada & Cedida ${ }^{13}$ & 2 & $\begin{array}{l}\text { IFB } \text { campus } \\
\text { Taguatinga }\end{array}$ \\
\hline Ana & 43 & $\begin{array}{l}\text { Dona de } \\
\text { casa }\end{array}$ & $\begin{array}{l}6^{\circ} \text { ano do fun- } \\
\text { damental }\end{array}$ & $\begin{array}{l}\text { Vive com } \\
\text { companhei- } \\
\text { ro }\end{array}$ & Própria ${ }^{14}$ & 4 & $\begin{array}{l}\text { IFB } \text { campus } \\
\text { Taguatinga }\end{array}$ \\
\hline
\end{tabular}

\begin{tabular}{|c|c|c|c|c|c|c|c|}
\hline \multicolumn{8}{|c|}{ Quadro 2 - Perfil dos filhos das entrevistadas } \\
\hline $\begin{array}{l}\text { Alu- } \\
\text { na }\end{array}$ & $\begin{array}{l}\text { Qtd. } \\
\text { filhos }\end{array}$ & $\begin{array}{l}\text { Idade } \\
\text { do fi- } \\
\text { lho(a) } 1 \\
\end{array}$ & $\begin{array}{l}\text { Escolaridade } \\
\text { do filho(a) } 1\end{array}$ & $\begin{array}{l}\text { Idade } \\
\text { do fi- } \\
\text { lho(a) } 2 \\
\end{array}$ & $\begin{array}{l}\text { Escolaridade } \\
\text { do filho(a) } 2\end{array}$ & $\begin{array}{l}\text { Idade } \\
\text { do fi- } \\
\text { lho(a) } 3 \\
\end{array}$ & $\begin{array}{l}\text { Escolarida- } \\
\text { de do fi- } \\
\text { lho(a) } 3\end{array}$ \\
\hline $\begin{array}{l}\text { Caro- } \\
\text { lina }\end{array}$ & 2 & 8 & $\begin{array}{l}2^{\circ} \text { ano do fun- } \\
\text { damental }\end{array}$ & 3 & (não estuda) & - & - \\
\hline $\begin{array}{l}\text { Fáti- } \\
\text { ma }\end{array}$ & 2 & 30 & $\begin{array}{l}\text { Ensino médio } \\
\text { completo }\end{array}$ & 18 & $\begin{array}{l}2^{\circ} \text { ano do en- } \\
\text { sino médio }\end{array}$ & - & - \\
\hline $\begin{array}{l}\text { Jane- } \\
\text { te }\end{array}$ & 3 & 37 & $\begin{array}{l}\text { Ensino médio } \\
\text { completo }\end{array}$ & 33 & $\begin{array}{l}\text { Ensino médio } \\
\text { completo }\end{array}$ & 14 & $\begin{array}{l}9^{\circ} \text { ano do } \\
\text { fundamental }\end{array}$ \\
\hline $\begin{array}{l}\text { Cláu } \\
\text { dia }\end{array}$ & 1 & 3 & Creche & - & - & - & - \\
\hline $\begin{array}{l}\text { Ra- } \\
\text { quel }\end{array}$ & 2 & 5 & $\begin{array}{l}\text { Não especifi- } \\
\text { cado }\end{array}$ & 1 & (não estuda) & - & - \\
\hline $\begin{array}{l}\text { Mari- } \\
\text { sa }\end{array}$ & 2 & 39 & $\begin{array}{l}\text { Superior com- } \\
\text { pleto }\end{array}$ & 37 & $\begin{array}{l}\text { Superior com- } \\
\text { pleto }\end{array}$ & - & - \\
\hline Ana & 2 & 22 & $\begin{array}{l}\text { Superior in- } \\
\text { completo }\end{array}$ & 10 & $5^{\circ}$ ano & - & - \\
\hline
\end{tabular}

\footnotetext{
${ }^{12}$ Todos os nomes foram substituídos para proteger a identidade das entrevistadas.

${ }^{13}$ Residência em nome do marido, que era viúvo e casou-se com a entrevistada em regime de separação total de bens.

${ }^{14}$ Residência em nome da ex-esposa do atual companheiro.
} 


\title{
3.1 Carolina
}

Carolina é casada, mãe de uma casal, tem residência própria obtida por meio de programa social que beneficiava residentes de uma invasão no Distrito Federal. Ela decidiu viver nesta invasão com o objetivo de conseguir a casa própria. Na ocasião da mudança para a invasão, já tinha um filho e depois teve uma filha. A filha, ainda bebê, acompanhava a mãe dentro da sala de aula, e o filho ficava na brinquedoteca. Carolina tem o ensino médio completo e, agora que a caçula tem três anos, está procurando emprego.

Carolina reconhece que o aprendizado de artesanato com resíduos sólidos, embora não tenha se tornado uma atividade profissional, trouxe mudanças na sua maneira de ver os materiais descartados. "Eu comecei a dar valor naquela coisinha que eu achava que era lixo e começava a jogar fora, eu vi que, realmente, eu podia aproveitar. Então, eu vi que no artesanato, a gente tem, realmente, um campo muito amplo" (CAROLINA).

Ela percebe sua situação de vulnerabilidade social e emocional quando frequentou o curso e relata que ele trouxe esperança de dias melhores:

\begin{abstract}
A minha participação no Mulheres Mil foi numa fase da minha vida que eu tava em situação de vulnerabilidade, onde eu morava numa invasão, na rua, né, no caso. Em busca, claro, da minha moradia. E onde eu morava dentro de um barraco de madeira. Um lugar onde não tinha banheiro, um lugar que, que não tinha luz. Claro que a gente pegava como gambiarra. A água também era gambiarra. Então, veio numa situação de, realmente, uma situação de que eu estava mesmo precisando pela minha autoestima estar afetada. Pelo desenvolver dos dias que estavam sendo cansativos, que estavam sendo sofridos na invasão. Então, realmente veio como um refúgio, veio como uma esperança de vida, uma esperança de dias melhores. E a partir do Mulheres Mil que eu voltei a sonhar, eu voltei a buscar melhorias, eu voltei a, realmente, a ter um convívio de amizade. Um lugar que tinha mulheres realmente que tinha força de vontade. (CAROLINA)
\end{abstract}

\section{Empoderamento}

Para Carolina, o compartilhar de experiências foi muito marcante e significativo, e trouxe repercussão na forma de enxergar o mundo e encarar a vida.

[...] E no curso a gente vê que, realmente, tinha mulheres que, naquele momento, tavam sofrendo muito, chegando num ato de depressão muito forte. E no desenvolver, a gente viu que, realmente, nós conseguimos mudar a visão pro mundo, a visão pros dias que a gente estava tendo, né? Que a gente podia superar e a gente buscou a superação. Acho que todas as mulheres daquele curso sentiu realizada, vendo o mundo de outra forma. $\mathrm{O}$ 
mundo que, realmente, mesmo em meio às dificuldades, a gente pode ser transformadas. (CAROLINA)

Esta fala de Carolina, que remete às mudanças ocorridas na percepção dela e das outras alunas sobre suas próprias realidades está de acordo com a "educação para o exercício do legítimo poder" (YANNOULAS, 2001, p.83 apud PRÁ, 2001), na qual aprendem a olhar para si mesmas e se autoanalisarem, valorizando suas trajetórias pessoais. Esta forma de abordagem leva ao fortalecimento da autoestima e ao empoderamento.

Carolina tem uma percepção da questão do tratamento diferenciado que a sociedade dá por gênero, mas segundo ela, após o curso, para uma mulher conseguir o que quer "Basta a gente querer, ter atitude, e persistir naquilo que uma hora dá certo". (CAROLINA)

\section{Relações familiares}

Em relação à família, ela reconhece que as relações melhoraram e se sente mais valorizada do que antes: "É... Hoje, hoje eu vejo que eu me sinto mais valorizada. [..] Acho que depois do curso continua me valorizando porque viu que eu tenho potencial e que eu posso melhorar realmente, mais". E complementa:

Então, assim, a partir daí a confiança no meio familiar foi bom. Por que, igual eu tava dizendo, é... querendo ou não eu estava numa situação, junto com a minha família, de... é... sem esperança nenhuma. Então, a partir do curso, depois que eu me animei, depois que eu me restabeleci, a, a minha força voltou; voltei a ter força, voltei a ter sonhos. Então, é... a minha família passou a viver o que eu tava vivendo naquele momento. (CAROLINA)

Ela relata que sempre participou ativamente da educação do filho (a caçula ainda não estuda), tanto em casa quanto na escola, e isso não mudou após o Programa: "tudo que é em relação a educação, eu sempre tento focar o máximo pra poder despertar nele curiosidade" (CAROLINA).

\section{Relações sociais}

Carolina conta que sempre teve poucos amigos, "Eu já vim, de berço, de uma pessoa não de ter muitas amizades. Não de ter um, um... é... muitos, muitos colegas", e que durante o curso, sentiu um laço de cumplicidade com a troca de histórias que gerou nela confiança nas pessoas: 
eu pude colocar as minhas dificuldades, colocar os meus desejos, pra outras pessoas ouvir. Então, eu senti uma confiança. E, realmente, as pessoas começaram a me ver de outros olhos porque elas passaram a me ouvir melhor e a me entender a situação que eu tô vivendo. Então, depois disso, é... o meu ciclo de amizade aumentou. O meu convívio com as pessoas aumentou (CAROLINA).

\section{Participação e cidadania}

Carolina já era bastante engajada em atividades relativas de participação, especialmente aquelas relacionadas à moradia prometida pelo governo. Após o curso, começou a participar de grupos na igreja que frequenta, de interesse da comunidade e trabalha na associação do condomínio onde vive (na tão sonhada casa própria).

Os relatos de Carolina corroboram Baquero e Baquero (2007, p.54-55). Para os autores, a ausência de empoderamento, relatada por Carolina como uma fase "sem esperança", refere-se "à alienação, impotência e desamparo", e sua aquisição, após o curso, quando ela diz que voltou a ter força e a sonhar, deu a ela controle sobre questões em várias dimensões de sua vida. Essa aquisição de controle também influenciou sua família, que "passou a viver o que eu tava vivendo naquele momento", e fortaleceu ainda mais sua participação comunitária.

\subsection{Fátima}

Fátima, 54 anos, é uma das alunas entrevistadas que se autodenominou "artesã" e já trabalhava com artesanato. Ela tem o $5^{\circ}$ ano do fundamental, é casada e reside em casa própria com o marido e o caçula dos dois filhos, que tem dezoito anos e cursa o $2^{\circ}$ ano do ensino médio. O mais velho, de 30, tem ensino médio completo.

\section{Empoderamento}

Fátima observou que sua forma de ver o mundo mudou e que se sente capaz de realizar coisas que antes não se sentia capaz. Agora, sente-se segura:

Por exemplo assumir uma oficina de artesanato como eu tô, como eu assumi agora, né? Antes eu era, assim, mais tímida, mais recatada, e tal. Às vezes tinha vergonha até de conviver, de conversar, de dialogar com as pessoas, né? E agora já tem mais um, mais essa abertura na minha vida. De, sei lá, de 
me aproximar mais das pessoas, de poder ensinar o que eu aprendi, né? Me sinto mais segura agora ((risos)). (FÁTIMA)

Fátima percebia a diferença de tratamento por gênero: "É, antes a gente via muita diferença, eu via muita diferença, né”, e passou a se sentir no direito de realizar coisas que antes achava que não podia: “[...] a gente aprendeu coisas que não sabia ainda a respeito desse direito da mulher, né, que agora a gente sabe que a gente tem, né, muito direito que pode ser, pode buscar, né, que antes eu não sabia”. (Fátima)

\section{Relações familiares}

Fátima foi apoiada pela família na decisão de participar do Programa, e se sentia valorizada no ambiente familiar. Ela relata que seria novamente apoiada se decidisse fazer um novo curso: "Ah, foi bem. Bem recebido. Porque eles gostam quando vê que eu tô fazendo algum curso, participando de alguma coisa, assim, eles gostam e me apoiam" (FÁTIMA). Em relação ao envolvimento com a educação dos filhos, diz que sempre foi de "pegar no pê", que se envolve mais que o companheiro por ter maior disponibilidade de tempo, e que depois de participar do Programa, "aprendeu muita coisa aqui, né, que a gente passa também pra vida pessoal, em casa, claro, né, em relação a família, os filhos. A gente aprendeu muita coisa aqui que a gente acaba levando pra educação dos filhos também”. (FÁTIMA)

\section{Relações sociais}

Em relação às pessoas de fora da família, Fátima relatou que sua confiança mudou "às vezes sim, às vezes não, né. Não sei, depende do grupo, assim, que eu teje integrado, né?". Também é interessante levar em consideração, embora não tenha sido possível perceber alterações muito significativas nas suas relações sociais, e que, no seu relato (ver citação anterior), ela afirma que antes era tímida e agora se sente mais confiante, e isto modificou sua forma de interagir com as pessoas, a ponto de se sentir segura para dar aula.

\section{Participação e cidadania}

Quanto à participação, Fátima já frequentava a Igreja, grupos religiosos e algumas oficinas de artesanato, e relata que depois do curso continuou nos grupos e cursos que já 
frequentava e passou a ministrar aulas de artesanato em um projeto, como voluntária: "Uma terapia ocupacional, né, que eu tô dando aula lá. Aprendendo coisas nova, também, que lá tem muitos outros cursos. Aí, eu procuro aprender coisas nova lá também" (FÁTIMA).

Baquero (2001 apud ANTUNES et al, 2004, p.1) nos diz que o capital social pode ser incrementado pela educação potencializando comportamentos participativos e cidadãos. $\mathrm{O}$ capital social, para o autor, é o processo e o instrumento de empoderamento do cidadão que pode mudar as relações pessoais e intercâmbios sociais, que geram mais redes de cooperação e solidariedade. As mudanças ocorridas na vida de Fátima após a participação no Programa, evidenciam melhora significativa na autoestima, aumento do empoderamento e ampliação das suas redes e relações sociais, indícios de aumento do capital social.

\subsection{Janete}

Janete é muito amiga de Fátima, são vizinhas de porta, e já frequentavam algumas atividades juntas quando buscaram o Mulheres Mil. Ela é casada, tem 56 anos, tem o $5^{\circ}$ ano do ensino fundamental e reside em casa própria com o marido e o filho caçula, de 14 anos, que está no $9^{\circ}$ ano do ensino fundamental. Os outros dois filhos são adultos e têm ensino médio completo. Janete, assim como Fátima, já trabalhava com artesanato e se autodeclarou “artesã”.

\section{Empoderamento}

Janete reconhece que ocorreram mudanças em sua vida após a participação no Programa e que se sente capaz de realizar coisas que antes não se sentia. "Pra mim mudou pra melhor. Que agora eu posso ver que muita coisa que eu pensava que não conseguiria fazer, agora eu boto aqui na minha cabeça e eu digo 'eu consigo, eu sou capaz'. Consigo!" (JANETE). Ela percebia que havia "discriminação" por ser mulher, e sem entrar em detalhes, relata que "depois do curso melhorou bastante o meu modo de ver, tudo. Melhorou muito" (JANETE). 


\section{Relações familiares}

A família de Janete a apoiou para participar do curso e ela relata que passou a confiar mais nas pessoas da família: "Eu confiava nelas e agora confio melhor ainda" (JANETE).

Com relação à educação dos filhos, Janete nos conta que ela e o marido sempre cobraram e continuam cobrando deles. O pai cobra ainda mais que ela. Bem humorada, ela fala que realiza revistas nas mochilas dos filhos: "quando chega do colégio eu revisto tudinho pra ver se tem alguma coisa diferente que não é deles, né? ((risos)). E, agora, continua do mesmo jeito, melhor ainda" (JANETE).

Janete relatou que o filho caçula participara recentemente de um projeto na escola, no qual ele vendeu as peças artesanais da mãe, que também lhe repassou conhecimentos de formação de preços, aprendidos durante o curso. Disse-lhe: "Meu filho, tira os artesanato que a sua mãe tem em casa e cria, né" (JANETE). Orgulhosa, contou que ele fora entrevistado por uma rede de TV na escola.

Desta forma, ainda que a família de Janete não se situe em grupos privilegiados, como coloca Bourdieu, ou faça parte de redes de alta densidade, como coloca Girolami, a maneira como ela e o marido transmitem informações, dentro e fora da família, o diálogo deles com os filhos e a clareza do projeto escolar, são fatores positivos na educação dos filhos, como coloca Coleman, e podem proporcionar melhor desempenho e maior longevidade escolares.

\section{Relações sociais}

Embora não tenha notado mudança em sua confiança nas pessoas, ela percebeu que está mais confiante em si para se relacionar com as pessoas, sentindo-se inclusive encorajada a dar aula em um projeto, como voluntária. “[...] eu era, assim, tímida. Depois do Mulheres Mil, sabe, passei a conversar mais. Agora, falo até demais, converso tudo. Foi muito, foi um curso maravilhoso pra mim" (JANETE).

\section{Participação e cidadania}

Janete conta que frequentava cursos de artesanato e, depois do Programa, continua frequentando. Começou a ensinar o que já sabe num projeto de uma igreja, como voluntária: "É uma igreja, sabe? Então eles ajudam muito as pessoa que tem problema, que tá em depressão, esse tipo... Então, a gente somos voluntária lá, sabe?”(JANETE). 


\subsection{Cláudia}

Cláudia tem 31 anos e ensino médio completo. É solteira e tem uma filha de três anos, que é criada pela avó (mãe de Cláudia) e frequenta creche. Depois que a filha nasceu, Cláudia começou a apresentar problemas psiquiátricos e não pôde amamentar a filha e nem cria-la. Pelas dificuldades de relacionamento com a mãe e o padrasto, alugou uma quitinete e foi morar sozinha, com ajuda financeira da família, e continua acompanhando o crescimento da menina. Apesar dos seus problemas pessoais, foi uma aluna extremamente participativa durante o curso e se envolveu em assuntos relativos ao grêmio do campus Taguatinga, trabalhando na formação de uma associação de artesãos do campus (que não se formalizou).

\section{Empoderamento}

Cláudia tem uma fala muito significativa em relação ao empoderamento e sentia necessidade de mostrar às pessoas que era capaz de superar o momento difícil que passava:

Então, pra mim, tava muito difícil. Mas eu, pelo menos, não tentava faltar, sempre tentava vim... Eu tentava me fortalecer; colocava aquilo na minha cabeça: "eu vou me fortalecer porque, é... por eu tar morando só, eu vou mostrar pra mim, mostrar pras pessoas que eu consigo! (CLÁUDIA)

Para ela "não foi só uma escola de... é... aprendizado só... uma reciclagem ou alguma outra qualquer coisa", Claudia reconhece o papel de fortalecimento de aspectos psicológicos que o Programa lhe deu: "Por mais que eu esteja assim, né, a autoestima mudou. Meu psicológico... e... foi indo, né... foi conseguindo desenvolver as coisas, né..." (CLÁUDIA).

Ela relata que não tinha esperanças de fazer um curso superior, mas que depois de participar do Programa conseguiu. Embora esteja enfrentando algumas dificuldades para se manter na faculdade neste momento, ela se sente extremamente realizada por ter conseguido acessar o sonhado curso superior: "Então eu achava, era uma das coisas que eu achava que jamais faria. Era um curso superior" (CLÁUDIA).

\section{Relações familiares}

As relações familiares de Cláudia são extremamente complexas e repletas de conflitos. Durante o curso e na entrevista, ela relatou muitas situações complicadas, especialmente entre 
ela e a mãe. Em relação às mudanças ocorridas em sua vida após o curso, Cláudia compara as percepções da família com as dela própria e de outras pessoas:

Pra eles [família] não foram mudança. Pra eles é como se [...] tivesse fazendo um... qualquer coisinha, qualquer cursinho. Tanto antes como os depois. Pra eles foram isso. Pra mim não foi. Agora, pra outras pessoas, não... as outras pessoas viram... até fisicamente, né... viram que eu fiquei diferente. Viram que eu ficava alegre... entendeu... As pessoas: “Ah, você tá fazendo isso? Tá aprendendo isso, aquilo outro, e tal!”. (CLÁUDIA)

Além da participação no Programa, Cláudia teve acompanhamento psicológico por algum tempo, e, depois de muitas dificuldades no relacionamento com a filha (intermediado por sua mãe), percebe que a menina está em melhores condições sendo criada pela avó. A consciência de si mesma e da dinâmica da própria família demonstram maturidade e capacidade de autoanálise muito interessantes:

Hoje em dia, eu ainda tenho que ser assim: "mãe, você acha que ela tá boa pra mim ir ver ela? Pra mim vê-la? Por que, pra ela não chorar e isso aquilo outro?". Por que eu não quero... hoje, eu só penso nela; só penso no bem estar dela. Não quero tirar ela de lá nem nada, porque as condições, como se fala, física, psicológica, financeira, tenho certeza que, é... pra mim, é pouco pra mim dá pra minha filha. Eu acho que ela ali com a minha mãe tá melhor... entendeu? (CLÁUDIA)

A filha de Cláudia ainda não está em idade escolar, portanto o envolvimento dela com esse aspecto não pode ser considerado, embora ela tenha sonhos em relação à educação e ao futuro da filha. "Hoje, eu sou bem mais velha pra fazer um curso superior, que ela possa fazer bem mais rápido. Que eu possa dar mais oportunidades pra ela de cursos, né, de outras coisas. [...] Então, eu tenho certeza que ela vai ser uma grande mulher [...]" (CLÁUDIA).

Embora as relações familiares de Cláudia sejam muito degradadas e envolvam muitos episódios de agressividade, a maneira como Cláudia encara sua realidade familiar melhorou e ela consegue lidar melhor com as situações que se apresentam, bem como com suas próprias emoções em relação a tudo isso.

\section{Relações pessoais}

A fala de Cláudia sobre as relações pessoais é bem interessante, pois ela relata que é "uma pessoa muito difícil de lidar. Eu sou, como se dizer, eu sou uma pessoa bipolar. Então, é complicado. Então, quando eu cheguei, foi difícil" (CLÁUDIA). Entretanto, Cláudia se 
destacou dentre as alunas, era conhecida por todas, tornou-se uma referência e superou dificuldades de relacionamento, em especial com mulheres:

eu fiz uma amizade com todo mundo. Acho que não teve um que eu não tenha feito; ainda mais com mulheres. Pra mim, o mais interessante foi com mulheres. Eu nunca gostei de fazer amizade com mulheres. [...] e aqui não: teve jovens, mais velhas. [...] E, assim, eu, aos poucos, fui gostando de cada uma. Acho que umas das coisas que... é... é... foi mais interessante pra mim. (CLÁUDIA)

Nos depoimentos de Cláudia, não se mostrou relevante a categoria participação e cidadania.

\subsection{Raquel}

Raquel, 35 anos, é dona de casa, tem ensino fundamental completo e mora com o companheiro (regime de união estável) numa residência alugada. Tem uma filha de cinco anos (escolaridade não especificada) que frequentou a brinquedoteca algumas vezes, e uma bebê, de um ano.

Para Raquel, a formação em artesanato fez com que valorizasse as atividades manuais que aprendeu com a família, antes vistas como passatempo: "[...] é que eu fazia crochê, mas eu não fazia nem ideia que isso era também artesanato. E eu aprendi, é... a valorizar mais, é... com o curso. Pra mim, era só um passatempo mesmo. Mas, aí, eu vi que era artesanato" (RAQUEL).

\section{Empoderamento}

Após o curso, Raquel sentiu-se mais motivada e corajosa para buscar formação, e o fato de ter filhos também passou a motivá-la: "Porque eu não tinha coragem antigamente. E eu tinha, é, como fazer porque eu era sozinha, não tinha filho. Não tinha coragem. Agora, hoje, e por causa dos filhos, a gente precisa, tem que ter coragem de ir atrás. Vontade, mesmo" (RAQUEL). 


\section{Relações familiares}

A família de Raquel a apoiou para que participasse do curso, e ela se sente valorizada pelas tarefas desempenhadas na família. Relativamente aos estudos da filha mais velha, ela relata que participa das atividades da escola e ajuda nos deveres, e que no Mulheres Mil, "[...] teve algumas aulas também que serviu pra abrir os olhos da gente que estudar, também, é muito bom. Faz a gente crescer pro mundo, pra gente mesmo...” (RAQUEL).

Zago (1988, p.70) afirma que nas classes populares, os pais, destituídos de capital econômico e material, mantêm uma relação positiva com a educação escolar, mesmo diante dos obstáculos materiais e insucessos escolares. De um modo geral, a única via que estes pais podem vislumbrar como possibilidade de integração social e profissional dos filhos é a escola. A fala de Raquel é um exemplo do que a autora coloca. Apesar de ter interrompido seus estudos e de suas dificuldades objetivas, ela se envolve com a educação da filha, que está em idade escolar, e, após a participação no Programa, ampliou o valor que atribui à educação, fator, nas palavras dela, que "faz a gente crescer pro mundo, pra gente mesmo" (RAQUEL).

\section{Relações sociais}

Raquel afirma que sua confiança nas pessoas diminuiu, embora não relacione isto diretamente com sua participação no Programa: "Acho que com um tempo, também, a gente vai desconfiando mais das pessoa... sei lá. A gente confia mais com o pé atrás ((risos))". (RAQUEL). Por outro lado, ela diz que a participação no Mulheres Mil foi boa "porque eu conheci muita gente. Algumas pessoas também ainda... é... ainda mantenho a... é, como se diz, a amizade, mesmo, de longe. E foi bom. ((risos))" (RAQUEL).

Em relação à categoria participação e cidadania, o depoimento de Raquel não demonstrou relevância.

\subsection{Marisa}

Marisa, 59 anos, era uma das alunas com melhores condições sociais. Ela ocupou uma das vagas remanescentes, que foram disponibilizadas para qualquer mulher que quisesse frequentar o programa. Casada pela segunda vez, com um senhor viúvo, vive na residência dele, segundo ela "cedida", pois casaram-se em regime de separação total de bens. Marisa tem 
dois filhos homens, adultos, ambos com formação superior. Ela os criou sozinha, após ter sido abandonada pelo primeiro marido quando o mais velho tinha três meses de idade. Tem formação superior, em Serviço Social, e, após o curso, passou a trabalhar como perita socioeconômica, avaliando as condições de famílias que tiveram os benefícios sociais negados pelo governo e contestaram as decisões.

\section{Empoderamento}

Marisa foi uma das alunas mais atuantes e presentes no curso. Teve papel preponderante mobilizando as colegas, ajudando os professores, envolvendo-se com atividades complementares, e dando sugestões. Embora fosse de nível social mais elevado, Marisa encontrava-se em situação de vulnerabilidade emocional, sem confiança nela mesma. Ela relata que entrou no curso por acaso:

[...] quando eu entrei aqui, eu tava, assim, com o astralzinho caído. E... Entrei aqui por um acaso, procurando alguma coisa que eu não sabia nem o que eu queria fazer. Aí, o rapaz me disse: "olha, só tem esse aqui, curso de Mulheres Mil. Não sei não...”. E eu pensei: “o que será isso, meu Deus?". Aí, eu fiz essa inscrição. No começo, saía de casa desanimadinha... Aí, fui melhorando, melhorando, melhorando. E, e tudo foi evoluindo. Aí, hoje, comparando hoje, é... a minha vida com aquele período de quando eu entrei, tá outra coisa. Né... Eu estou mais confiante... Já arrumei, assim, até um trabalho pra eu fazer. E tô bem tranquila, graças a Deus. (MARISA)

Marisa relata que ficou mais forte após a participação no curso, e que isso afetou seu relacionamento com os filhos: “[...] a gente fica mais forte, né. Quando você tá bem, faz uma coisa, assim, que tá gostando; que você se sente bem! Você fica mais forte, pra enfrentar os desafios, pra ajudar os filhos, né" (MARISA). O curso também trouxe crescimento no sentido de não se acomodar e de estar sempre criando algo novo, por meio das técnicas de artesanato aprendidas:

Então, é... eu não fico parada. Quando eu estou parada, eu estou sempre inventando. Aí, eu vou lá no meu escritoriozinho, no fundo de casa, e pego umas conchinhas, pego uma coisa, pinto. Se não ficou boa, eu faço de novo... né... vou nas conchinhas fazer um porta retrato. E aquilo passa um dia... né... (MARISA)

\section{Relações familiares}

Os filhos de Marisa a apoiaram na decisão de participar do curso, embora o marido não desse valor e achasse que ela gastava demais com os materiais de artesanato. "Ah, você 
gasta muito dinheiro comprando material e isso não vai render nada. Você não vai conseguir ganhar nem o que você gastou. Você gasta dinheiro e fica só dando de presente pros outros" (MARIDO DE MARISA). Essa percepção foi se modificando à medida que ela começou a fazer as peças artesanais:

Não acreditaram muito. "Que curso é esse? Que que é isso? Mulheres Mil? Cê vai fazer o que lá?". Aí eu explicava... é, aí foi indo. Aí, eu comecei a aparecer com as peças em casa... né. Aí, depois que eu comecei a aparecer com as peças, eu tenho um, assim, bastante netos, e fui envolvendo os netos também... né... no, assim, pra fazer... mexer com artesanato. E aí, eles começaram a acreditar... e foi a partir daí, né. E foi bom... (MARISA)

Pelas mudanças que o Programa lhe proporcionou, Marisa acredita que, hoje, o marido a apoiaria e os filhos dariam força novamente, caso decidisse participar de algum outro programa ou curso. Ela, pessoalmente, também acha que melhorou na sua forma de se relacionar, por estar com uma atitude mais positiva:

É... Por a gente melhorar o astral, eu acho que tudo melhora. Né? Quando cê tá com baixo astral, você não vê, assim, coisas positivas, assim... até nas pessoas! Você fica negativa demais, assim... Aí, por a gente melhorar, você ter novas perspectivas, eu acho que é até automático que a gente melhore, assim, no relacionamento com quem está ali convivendo conosco. Eu acho que eu melhorei. (MARISA)

Marisa sempre teve envolvimento na educação e em outros aspectos da vida dos filhos, e depois do curso teve mais abertura para se envolver e cobrar deles determinadas atitudes que podem lhes trazer benefícios: “... a gente nunca deixa de dar palpite, de estimular os filhos, de... dar sugestões, assim, pra eles progredirem na vida... e, eu já fazia isso e continuei fazendo. Né... só que de uma forma, assim, né, até com mais abertura, eu acredito" (MARISA).

\section{Relações sociais}

Quanto às relações fora do contexto familiar, Marisa acha que permanecem iguais, embora reconheça que a interatividade e a união do grupo fortaleceram as alunas:

Parece que, é... daquilo, do curso do Mulheres Mil, as coisas deslancharam, né... e, o grupo foi muito bom, daqui do curso. A interatividade que aconteceu, [...] grupo ficou muito unido... e eu acho que nós saímos daqui fortalecidas e com isso a gente fica corajosa... né... eu fiquei corajosa... (MARISA) 
Como bem colocou Marisa, as relações que foram estabelecidas dentro do grupo das alunas geraram confiança e cumplicidade entre elas, unindo o grupo, trazendo força e coragem às mulheres. Desta forma, o capital social decorrente do Programa Mulheres Mil, de acordo com Baquero e Baquero (2007), foi uma construção individual de cada uma das participantes, mas sua existência só foi possível por meio de relações de confiança estabelecidas entre elas no decorrer do curso.

Ela relata, também, que sua forma de lidar com pessoas que precisam de ajuda mudou, e passou a ensiná-las a "colocarem a mão na massa, porque cê não pode entregar tudo pronto. Às vezes a pessoa chega, assim, reclamando: 'ah, tô passando dificuldade e tal'. Fala: 'então, faz isso, isso e isso. Vende!" (MARISA). Essa colocação de Marisa é muito significativa e reflete a educação para exercício da cidadania e para o empoderamento desenvolvida no Programa. Hoje, ela entende que oferecer ajuda é dar ao outro meios e ferramentas para que ele próprio possa dar seus passos.

\section{Participação e cidadania}

Marisa não menciona, na entrevista, a participação em grupos, entretanto, sua ocupação como perita socioeconômica e o depoimento acima, demonstram que Marisa tem um papel mobilizador importante na vida de pessoas em situação de vulnerabilidade social, e isto é um aspecto relevante para a categoria participação e cidadania.

\subsection{Ana}

Ana, 43 anos, é dona de casa, tem o $6^{\circ}$ ano do ensino fundamental e vive com o companheiro na casa da ex-esposa dele, com duas filhas. A filha mais velha, de outro relacionamento de Ana, tem 22 anos e cursa o ensino superior. A nova, com 10 anos, filha do atual companheiro, está no $5^{\circ}$ ano do ensino fundamental. A caçula, que frequentou a brinquedoteca, tem um problema de saúde que afeta o fígado, pode vir a fazer transplante, e pela demanda da saúde da filha, Ana não consegue realizar tantas coisas quanto gostaria:

Só não evoluí mesmo porque eu tenho ela [referindo-se à filha de 10 anos], né, e ela tem problema de saúde. Aí, eu entrei num serviço; não fiquei nem um mês completo, tive que sair... por causa dela. Mas o curso pra mim foi ótimo, mas eu não pude dar continuidade no curso não, né. Nem continuar 
fazendo os trabalhos... Porque, como eu tenho ela que tem problema de saúde, eu não posso... Praticamente eu vivo pra ela. (ANA)

Os relatos de Ana sobre a maternidade corroboram o que afirmam Griffiths e Smith (1990 apud REAY, 1995, p.339). Para as autoras, a maternidade é mais do que uma relação íntima entre mãe e filho, somente pessoal e emocional. É, também, um processo de trabalho que envolve tempo, esforço, e o uso e gestão dos recursos da família, o que ocorre no ambiente familiar, mas é moldado por diversas contingências, no caso, a saúde da filha.

\title{
Empoderamento
}

Para Ana, a participação no curso possibilitou que vislumbrasse a possibilidade de se dedicar à casa e ter outras atividades, e isto representou uma renovação em sua vida, através do aumento da autoestima e da coragem em empreender coisas novas:

\begin{abstract}
Antes, eu achava, assim, acho que nunca conseguia fazer nada... por mim só, né... E, hoje, eu acho que sim. Hoje, eu... eu acho que posso dedicar à casa e... fazer minhas coisas e ter participação fora, também, né? Assim, faço meus artesanato, posso ter minha vida diferente, na rua. [...]. Porque, às vezes, não fazia nada, achava ali: "Ah, minha vidinha vai ser só essa". Depois que eu fiz o curso, a gente renova a vida, né? Renova, assim, né, pro outro mundo. [...] Achava que nunca ia aprender nada, né... [...]. E aprendi, ué, aprendi muita coisa boa no artesanato. Hoje, acho que eu me sinto mais coraj... Mais com... sei lá, autoestima... hoje, né? Por ter feito o curso, ter participado... É isso, acho... Foi bem melhor, depois do curso. Fiquei bem melhor... Eu, é..., eu tenho mais capacidade de evoluir mais. (ANA)
\end{abstract}

O discurso de Ana se revela um pouco contraditório no decorrer da entrevista, e, em alguns momentos, uma fala se revela o oposto da outra. Embora Ana relate que "Por ser mulher, ser tratada diferente, não. Nunca me senti assim, não. Sempre me senti igual", na pergunta seguinte ela diz que quem vive dentro de casa "nunca tem participação em nada!", e complementa:

depois que eu fiz o curso, sim, eu achei que [...] a mulher tem a vida, pode ter a vida dela. Porque, antes, a gente fica pensando que depende só de marido, né, vive só ali... Depois que eu fiz o curso, não. Eu vi que eu posso evoluir, que eu posso aprender. Que eu posso ter minha vida lá fora, né? ((risos)). Mas, é isso. (ANA) 


\title{
Relações familiares
}

Ao ser perguntada se fora apoiada para participar do curso, ela diz que "Eles sempre me deram muita força, né...", mas logo em seguida emenda dizendo que sua vontade de participar do curso, para a família, seria em vão, pois teria que parar para cuidar da filha a qualquer momento "Ah, você vai fazer o curso, depois não pode levar a frente, né? Aí, praticamente não adiantou" (FALA DOS FAMILIARES). Assim mesmo ela diz que "[...] Mas, eles me deram muita força enquanto eu tava fazendo, né..." (ANA).

Embora diga que recebera apoio enquanto estava fazendo o curso, o companheiro de Ana "achou um pouquinho ruim" e:

\begin{abstract}
nunca quer que saia de casa, né, ainda mais com ela. Ele acha assim: "Ah, essa menina tem problema; cê vai sair...". Hoje, igual quando cê ligou ontem, né, ele já foi logo falando: "Ah, se for pra curso, vê lá o que é, porque tá vendo que não dá pra sair, tem que levar a menina na natação". Hoje ela faz natação, né... Ele não encarou muito bem quando cê ligou ontem, assim. Ele achou que era pra fazer um novo curso de novo, né? Mas, aí, igual eu falei pra ele: "Mas se for curso, eu vou fazer. Não importa". (ANA)
\end{abstract}

Assim mesmo, Ana se sente valorizada pelas tarefas realizadas em casa, antes e depois do curso: "Eles dá valor, sim, muito isso. Eu sempre fui muito dedicada a casa, filhos, né?" (ANA). Em relação à educação das filhas, ela fala que tem papel preponderante, e isso não se alterou com o curso. Ana está sempre envolvida para garantir que as filhas deem prosseguimento aos estudos. O marido se envolve com a educação durante as atividades que podem ser desempenhadas em casa, por exemplo, auxiliar em tarefas da escola.

Apesar das contradições no discurso de Ana, ela percebe que não tem todo o apoio do marido para participar das atividades que gostaria e isto não se modificou, o que pode ser visto nas falas acima. Ela também não percebeu mudança significativa na sua relação com a educação das filhas.

\section{Relações sociais}

Ana é enfática ao dizer que passou a confiar mais nas pessoas: "Tem pessoas muito boa, né? Ainda... Eu me dei muito bem com os grupo. Passei a confiar bastante nos grupo fora" (ANA). Sua percepção da importância de se participar de grupos foi reforçada ao ser questionada sobre os valores que considera importante passar para as filhas. Para ela, a 
participação em grupos reforça a reciprocidade e os valores que ela passa para as filhas: "o respeito com os outros, ajudar... participação... participação em grupos, né? É, eu sempre falei pra ela, né, que eu... o que a gente fala, o que a gente dá é o que a gente recebe, né?" (ANA, grifo nosso)

Na categoria participação e cidadania, os depoimentos de Ana não demonstraram relevância.

\subsection{Análise da relevância das categorias}

Para avaliar a relevância das categorias na vida de cada uma das participantes, foi elaborado o Quadro 3 - Relevância das categorias por entrevistada, no qual foi atribuída uma nota de 0 a 3 , de acordo com a influência exercida para categoria de análise por entrevistada. A escala utilizada foi: 0 - irrelevante, 1 - pouco relevante, 2 - relevante, e 3 - muito relevante.

\begin{tabular}{|l|c|c|c|c|}
\hline Quadro 3 - Relevância das categorias por entrevistada \\
\hline $\begin{array}{l}\text { Categorias } \\
\text { por } \\
\text { entrevistada }\end{array}$ & Empoderamento & $\begin{array}{c}\text { Relações } \\
\text { familiares }\end{array}$ & $\begin{array}{c}\text { Relações } \\
\text { sociais }\end{array}$ & $\begin{array}{c}\text { Participação } \\
\text { e cidadania }\end{array}$ \\
\hline Carolina & 3 & 3 & 3 & 1 \\
\hline Fátima & 2 & 1 & 2 & 2 \\
\hline Janete & 3 & 1 & 2 & 2 \\
\hline Cláudia & 3 & 1 & 3 & 0 \\
\hline Raquel & 2 & 2 & 1 & 0 \\
\hline Marisa & 3 & 3 & 2 & 2 \\
\hline Ana & 2 & 0 & 3 & 0 \\
\hline \multicolumn{4}{|l|}{ Escala: $0-$ irrelevante, $1-$ pouco relevante, 2 -relevante, e 3 - muito relevante } \\
\hline
\end{tabular}

A partir do Quadro 3, foi elaborado o Quadro 4 - Relevância de cada categoria de análise, que traz quantas vezes cada escala de relevância foi atribuída a uma categoria em números absolutos. Para compreensão de como foi elaborado, trazemos o seguinte exemplo: a escala irrelevante, que não foi percebida em nenhuma das entrevistas na categoria empoderamento, resultou em 0 no quadro. Já a escala muito relevante foi percebida em quatro das sete entrevistas na mesma categoria. 


\begin{tabular}{|l|c|c|c|c|}
\hline \multicolumn{6}{|l|}{ Quadro 4 - Relevância de cada categoria de análise } \\
\hline & Empoderamento & $\begin{array}{c}\text { Relações } \\
\text { familiares }\end{array}$ & $\begin{array}{c}\text { Relações } \\
\text { sociais }\end{array}$ & $\begin{array}{c}\text { Participação } \\
\text { e cidadania }\end{array}$ \\
\hline 0- irrelevante & 0 & 1 & 0 & 3 \\
\hline $\begin{array}{l}\text { 1- pouco } \\
\text { relevante }\end{array}$ & 0 & 3 & 1 & 1 \\
\hline 2- relevante & 3 & 1 & 3 & 3 \\
\hline $\begin{array}{l}\text { 3- muito } \\
\text { relevante }\end{array}$ & 4 & 2 & 3 & 0 \\
\hline
\end{tabular}

O Gráfico 1 - Relevância do Programa por categoria de análise, foi construído a partir do quadro 4, acima, e mostra, por meio de barras, cada escala de relevância por categoria de análise.

Gráfico 1 - Relevância do Programa por categoria de análise

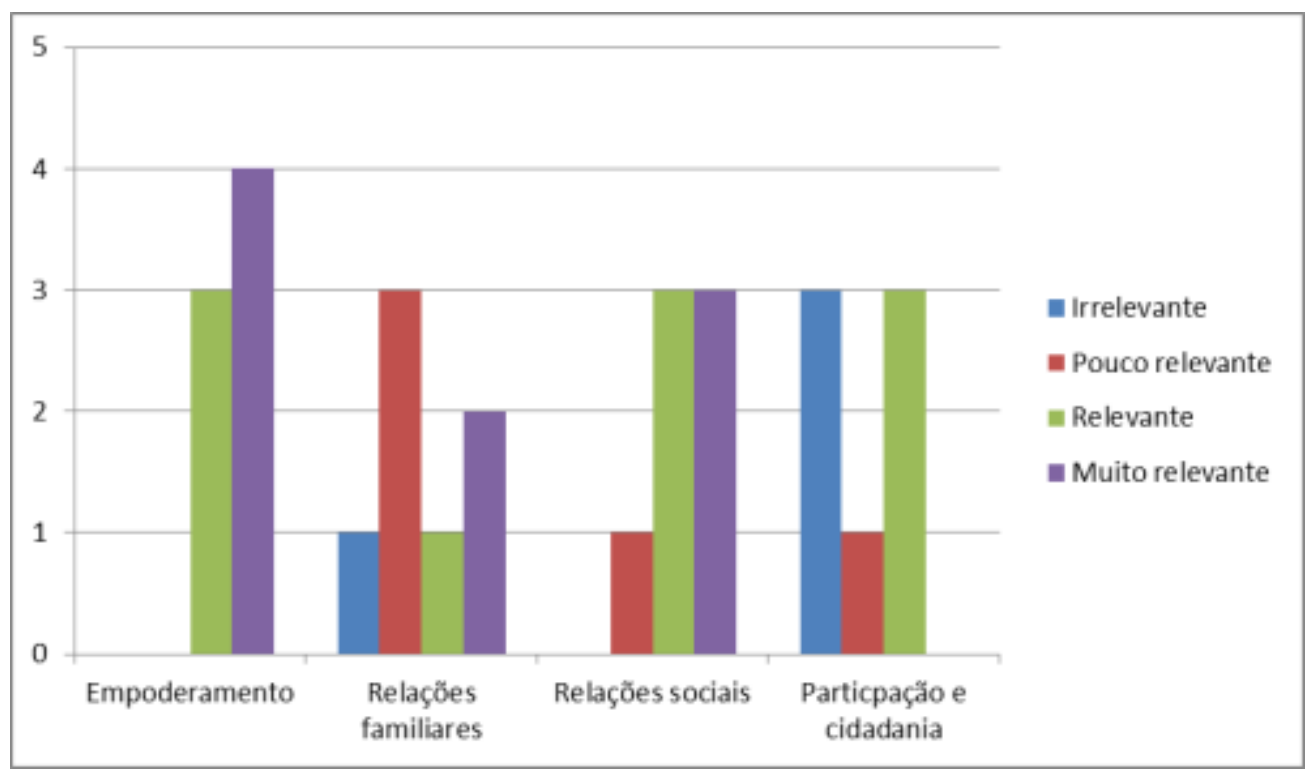

As falas das alunas permitem observar que para todas elas, houve mudança em relação ao empoderamento, sendo ele relevante para quatro delas e muito relevante para três. Os relatos foram de mudanças na percepção de empoderamento por gênero, fortalecimento com a cumplicidade criada no grupo, sentimento de estarem aptas a realizar coisas que antes não se sentiam capazes, melhoria da autoestima, aptidão para lidar com seus problemas emocionais e capacidade de sonhar e vislumbrar um futuro melhor. Esta análise permite afirmar que, dentre as categorias analisadas, a maior influência do Programa Mulheres Mil no campus Taguatinga foi o aumento do empoderamento das participantes. 
A segunda categoria com maior expressão foi relações sociais, que se mostrou muito relevante para três, relevante para outras três e pouco relevante para uma das entrevistadas. Esta categoria não foi irrelevante para nenhuma das participantes. Todas as alunas observaram mudanças nas suas relações sociais, por meio de maior confiança nas pessoas e nos grupos, melhor capacidade de interagir socialmente e criação (e manutenção) de vínculos com mais pessoas, inclusive de perfis diferentes daqueles que se costumava interagir.

Relações familiares foi a terceira categoria de maior influência na vida das mulheres, sendo irrelevante para uma delas, pouco relevante para três, relevante para uma e muito relevante para duas delas. As principais mudanças percebidas foram em relação ao apoio familiar na decisão de participar de novos cursos, maior valorização delas pela família, ampliação do valor atribuído à educação dos filhos - com maior envolvimento nessa área, e maior confiança nos familiares.

Os dados nos permitem concluir que a categoria participação e cidadania foi a que menos teve expressividade na vida das alunas, sendo irrelevante para três, pouco relevante para uma e relevante para três delas. Para nenhuma delas houve mudanças muito relevantes nesta área. Algumas passaram a se envolver em atividades ligadas a participação e cidadania e outras, que já tinham características relacionadas a esta categoria, não mudaram seu comportamento, ou mudaram pouco.

\subsection{Questão central e objetivos}

Para finalizar a análise, retoma-se, aqui, a questão central e os objetivos definidos na metodologia para que sejam tecidas as considerações.

A questão central é: Qual a relevância do Programa Mulheres Mil para o capital social das participantes?, e se desdobra nos seguintes objetivos:

- O objetivo geral desta pesquisa é demonstrar se o Programa Mulheres Mil realizado no campus Taguatinga do IFB teve efeitos no capital social das alunas e como influenciou suas vidas.

\section{Objetivos específicos}

- Identificar se o Programa teve efeitos no capital social das alunas e de que forma influenciou suas vidas;

- Analisar a relevância das categorias de análise para as alunas e para o Programa; 
- Verificar se foram alcançados os objetivos do Programa;

- Apresentar, a partir dos resultados da pesquisa, um produto técnico com sugestões para o Programa.

O Programa Mulheres Mil no campus Taguatinga se mostrou muito relevante na vida das participantes, especialmente nas questões relativas a empoderamento e relações pessoais. Para as relações familiares, o Programa teve influência relevante, e nos aspectos ligados a participação e cidadania, se mostrou pouco relevante.

O Programa teve influência positiva, ainda que em níveis diferentes, em todas as categorias de análise do capital social consideradas nesta pesquisa, especialmente em empoderamento, o que permite afirmar que ele é muito relevante para o capital social das alunas. É interessante relembrar e reforçar que o empoderamento é um conceito complementar ao capital social e tem sido apontado como fator determinante na manutenção dos efeitos do capital social.

Ainda que no aspecto de participação e cidadania não tenha havido mudanças significativas, a análise das entrevistas por categorias permite afirmar que o Programa Mulheres Mil amplia o capital social das mulheres por meio de maior empoderamento, melhoria e ampliação das redes sociais e fortalecimento de comportamentos familiares positivos. A pouca relevância desta categoria, de indiscutível importância para o Programa e para o capital social das alunas.

É notório que estas mulheres saíram empoderadas, com mais autoestima, capazes de sonhar e realizar coisas que antes não se sentiam capazes. Elas também ampliaram e melhoraram seus círculos sociais e reforçaram suas relações familiares de forma positiva. Estas mulheres, agora mais conscientes de quem são e de seus papeis, estão fortalecidas e encorajadas e podem ser protagonistas de suas histórias, tornando-se instrumentos mais influentes de mobilização em suas famílias e comunidades.

Quanto à consecução dos objetivos do Mulheres Mil, caso se tome por base os cinco elencados na Portaria que institui o Programa, pode-se afirmar que ele alcançou quatro deles: 


\section{I - Possibilitar o acesso à educação:}

O acesso ao curso de Artesanato com Resíduos Sólidos foi inclusivo e afirmativo, e permitiu a entrada de mulheres em situação de vulnerabilidade (ainda que emocional), sendo uma oportunidade de retorno aos estudos para a maioria delas.

\section{II - Contribuir para a redução de desigualdades sociais e econômicas de mulheres:}

O fortalecimento da autonomia das mulheres, seu empoderamento, a influência positiva nas suas relações sociais e familiares são aspectos relevantes que, certamente, podem contribuir para a redução das desigualdades sociais destas mulheres.

Quanto à redução de desigualdades econômicas, houve baixa inserção profissional delas na área: duas delas, que já trabalhavam com artesanato, declaram serem artesãs, as outras declaram usar o artesanato como terapia ocupacional, ou eventualmente. Outra aluna declarou que seu fortalecimento, após a participação no Programa, permitiu que começasse a trabalhar, mas como perita socioeconômica. Embora os aspectos ligados ao fortalecimento subjetivo das mulheres também sejam fatores que possam contribuir para a redução de desigualdades econômicas (haja vista as conexões positivas do capital social com a economia), a inserção profissional é um aspecto importante e deixa uma questão em aberto, que demandaria outra investigação, a fim de compreender a baixa inclusão delas no mundo do trabalho.

\section{III - Promover a inclusão social:}

Embora o aspecto de participação e cidadania tenha sido pouco relevante nas transformações das alunas, o aumento e fortalecimento do capital social fez com que se tornassem protagonistas de suas vidas, autônomas, com a autoestima elevada, capazes de buscar a realização de seus sonhos e objetivos. Isto também é inclusão social.

\section{IV - Defender a igualdade de gênero:}

Pode-se afirmar que o curso, como foi conduzido no campus Taguatinga, defendeu a igualdade de gênero, embora esta questão não tenha ficado totalmente esclarecida e enraizada nas mulheres. Nas falas das alunas, foi possível identificar que elas conseguiram perceber algumas diferenças no tratamento que recebiam por serem mulheres, mas não conseguiram aprofundar estas percepções e nem articular esse assunto a áreas diferentes de suas vidas. Isso 
nos leva a crer que este é um aspecto que deveria ter sido trabalhado com as mulheres em maior profundidade, mas que, ainda sim, teve repercussões em suas vidas.

\section{V - Combater a violência contra a mulher:}

Embora o tema da violência contra a mulher tenha sido levado às alunas durante o curso, a investigação aqui conduzida não permitiu revelar se este objetivo foi alcançado. 


\section{PRODUTO TÉCNICO}

Considerando as abordagens teóricas trazidas nesta pesquisa e partindo da análise das entrevistas, a contribuição técnica para esta investigação compõe-se de sugestões de melhoria para o Programa, com vistas à ampliação do seu potencial de geração de capital social, de forma que o Mulheres Mil exerça ainda mais influência nos aspectos relacionados ao capital social. Também são trazidos, como contribuição, outros aspectos observados durante a execução do Programa e apontados pelas alunas entrevistadas.

A justificativa para a contribuição relativamente ao capital social, nos aspectos positivos deste capital, se dá por ele ser um fator que pode ser estimulado pela educação e permitir às participantes articulações sociais com vistas à melhoria de suas vidas e transformações sociais. Também se justifica, pois, conforme visto no referencial teórico, que as mulheres podem ter papel central na mobilização do capital social dentro de suas famílias e em suas comunidades.

Desta forma, sendo o Programa Mulheres Mil uma política educacional de inserção socioprofissional para mulheres, o capital social, estimulado de maneira positiva (sem desresponsabilizar o Estado, considerando o perfil de mulheres atendidas e suas vidas e sem colocá-lo como uma solução mágica para todos os problemas das alunas e da sociedade), pode ser um aspecto para que os objetivos do Programa sejam melhor alcançados e as mulheres tenham maiores condições de transformarem suas vidas para melhor.

Sugere-se, dessa forma, uma abordagem que integre o capital social na metodologia do Programa e oriente melhor as práticas pedagógicas e diretrizes curriculares dos cursos ofertados. Seguindo as categorias de análise definidas para esta pesquisa, reforça-se a necessidade de se trabalhar: empoderamento, relações sociais, relações familiares, e participação e cidadania.

O empoderamento já é um tema bastante enfatizado no Programa e consta na metodologia. As temáticas relacionadas aos direitos das mulheres, questões de gênero e protagonismo, bem como dinâmicas como o mapa da vida, são essenciais para a melhoria da autoestima e o empoderamento das alunas.

$\mathrm{Na}$ análise das entrevistas evidenciou-se que as questões de gênero não ficaram completamente claras para as alunas. Algumas reconheceram que sentiam discriminação e 
que recebiam tratamento diferenciado por serem mulheres, mas esta questão não ficou completamente esclarecida para elas. Não ficou claro, por exemplo, que elas percebam estas questões no ambiente familiar. Desta forma, recomenda-se que as questões de gênero e as condicionalidades a que mulheres estão expostas, simplesmente pelo fato de serem mulheres, sejam aprofundadas e contextualizadas nas diversas esferas de suas vidas.

O programa fala da importância de se trabalhar relações interpessoais, mas é pertinente que as relações familiares e as sociais sejam trabalhadas de forma articulada, porém, distinta.

Relativamente às relações familiares, é importante que elas sejam conscientizadas do esforço que, em geral, empreendem no ambiente familiar, especialmente aquelas que são mães. Este esforço, representado pelos cuidados com a casa e com os membros da família, geralmente são naturalizados e não compartilhados. As alunas também devem estar cientes de todo tipo de violência que podem ser vítimas e formas de se defender. Elas precisam estar alertas para formas de desvalorização da mulher e de suas atividades, que nem sempre são muito claras, podendo ser sutis e até "engraçadas". Também devem estar cientes das formas que assumem os relacionamentos abusivos e como se defender deles, e fortalecidas para que seu protagonismo seja exercido, também, dentro da família.

Dentro das relações familiares, é interessante conscientizar àquelas que são mães de seu papel como mobilizadoras da educação de seus filhos, e que a educação deles pode ser influenciada positivamente pelo retorno delas aos estudos, ou na busca por melhores condições de vida. De qualquer forma, é preciso ficar claro para as mulheres mães, especialmente para as que trabalham, que os pais também devem participar da educação dos filhos (bem como de outras atividades relacionadas aos cuidados e bem estar da família).

As temáticas de relações sociais são fundamentais para a construção de laços sociais baseados na confiança e no sentimento de reciprocidade. É interessante destacar, aqui, o conteúdo da fala de Cláudia, que mesmo sendo uma pessoa "difícil de lidar", se surpreendeu ao conseguir fazer amizades com mulheres durante o curso, fato inédito em sua vida. No ambiente de sala de aula, com outras mulheres, unidas pelo vínculo da cumplicidade gerado pelas dinâmicas (com destaque para o mapa da vida) e pelo convívio, existe um ambiente muito positivo para se trabalhar as questões de sororidade entre as mulheres e a conscientização de sua força, principalmente quando estão unidas. 
Também é relevante que as atividades voltadas para os temas das relações sociais e familiares levem as participantes a refletirem sobre sua maneira de se relacionar, como reagem nas interações sociais, suas formas de defesa e ataque. Para tanto, é interessante que sejam estimuladas a se autoanalisarem constantemente e a perceberem as relações como uma via de mão dupla (reciprocidade), com suas atitudes também moldando as interações.

Embora essa categoria tenha tido pouca relevância nas alunas entrevistadas, os aspectos relativos à participação e cidadania constam nos documentos do Programa Mulheres Mil e têm relação estreita com o capital social. Nas atividades relativas à participação e cidadania, devem ser trabalhados não somente os direitos que lhes assistem, mas, especialmente, onde e como podem buscar estes direitos.

As alunas devem saber o funcionamento e, preferencialmente, conhecer pessoalmente, ao menos, uma instância de participação, como conselhos, Câmaras e assembleias, conferências, reuniões de administrações regionais, sedes de governos, ouvidorias, promotorias públicas, entre outros. Também é desejável que conheçam, pelo menos, um caso bem sucedido de cooperativa, associação ou iniciativa de economia solidária. Além disso, devem ser conscientizadas sobre a importância de se unirem a grupos informais, com os quais mantenham afinidade a fim de fortalecerem suas comunidades. Elas também devem saber como e onde emitirem documentos.

Outra forma de trabalhar participação e cidadania, de acordo com Campbell (2003 apud SILVEIRA, 2005, p.60), seria privilegiando, nas aulas e nas atividades escolares, discussões relacionadas à resolução de problemas e às estratégias de ação nas comunidades mais próximas das alunas, enfatizando o serviço comunitário voluntário, que poderá gerar sentimentos de confiança, cooperação e civismo.

Às alunas também deve ser oportunizado conhecer pontos turísticos e cívicos de suas cidades. Visitas a centros culturais e participação em eventos artísticos devem ser incentivados. Elas devem ser conscientizadas de que, também, são parte integrante desses espaços; que podem frequentá-los livremente, e que o acesso à cultura e ao lazer são importantes para todos.

Além do estímulo dos aspectos ligados às categorias analisadas, relacionadas ao capital social, são trazidos alguns aspectos observados na execução do Programa, na análise dos documentos institucionais e outros, trazidos pelas falas das alunas entrevistadas, que podem contribuir para o aperfeiçoamento do Programa. 
Uma questão a ser debatida é a exigência de $75 \%$ de presença para a obtenção do certificado. Verifica-se que, hoje, mesmo nos cursos que não são voltados para pessoas em situação de risco, esta exigência não é fácil de ser cumprida. No caso do Programa Mulheres Mil - voltado para mulheres com dificuldades de diversas ordens, isto se torna ainda mais difícil. Sabe-se que este debate envolve a legislação nacional da educação, porém, deve ser ressaltado esta exigência é um fator que pode desestimular as alunas pela dificuldade de receberem o certificado ao final. No caso do curso de Artesanato com Resíduos Sólidos, das 100 alunas matriculadas, somente 25 cumpriram esta exigência e obtiveram o certificado. Outras cerca de 25 permaneceram frequentando, mas não cumpriram a frequência mínima para recebe-lo.

Dentre as observações das alunas em relação aos pontos positivos e negativos e ao que mudariam no Programa, muitas delas relataram que o curso deveria ter continuidade ${ }^{15}$, tanto por meio de novas turmas (para receber outras mulheres que necessitam), quanto de forma seriada, para que uma mesma mulher possa participar novamente, aprofundando cada vez mais seus conhecimentos.

Algumas alunas sugeriram que houvesse mais aulas práticas, no caso, de artesanato, e que o curso fosse mais longo, talvez com mais aulas na semana. Entretanto, cabe aqui a ressalva de que, das mulheres entrevistadas, somente uma exerce atividade profissional fora de casa (perita socioeconômica) e outras duas exercem a ocupação de artesãs, como autônomas. Desta forma, esta fala teria que ser confrontada com a realidade das mulheres que trabalham, pois o aumento do número de aulas poderia ser impeditivo a sua participação no Programa. De qualquer maneira, o aumento das atividades práticas direcionadas para a formação artesanal não poderia ocupar o espaço das atividades voltadas para os aspectos de formação cidadã, trabalhados no Programa e aqui reforçados: empoderamento, relações familiares, relações sociais e participação e cidadania.

Cláudia, uma das participantes da pesquisa, sentiu falta de espaço para que as alunas pudessem participar das decisões relativas ao planejamento das atividades do curso. Este aspecto, dentro das possibilidades que o Programa e a operacionalização do dia a dia permitem, pode ser um fator bem interessante, possibilitando mais autonomia às mulheres. Isto poderia criar laços de responsabilidade delas com as atividades sugeridas, reforçando os

\footnotetext{
${ }^{15}$ No campus Taguatinga o Programa aconteceu somente no ano de 2013, com o curso de Artesanato com Resíduos sólidos. Desde minha saída da coordenação local, em fevereiro de 2014, nenhum curso fora ofertado.
} 
aspectos de participação e relações sociais, formando um campo interessante de mediação de interesses entre elas, e entre professores e alunas.

Alguns aspectos do Programa foram percebidos como positivos e merecem nota. A brinquedoteca representou uma "despreocupação" nas palavras de Carolina, que podia frequentar o curso sem ter que deixar o filho com outras pessoas. Outro fator mencionado foi a provisão de lanches, que pode ser o diferencial na disposição e aprendizado de algumas alunas que chegam sem ter se alimentado.

Embora seja uma política de formação profissional, dentre os objetivos do Programa (Brasil, 2011c) não consta nenhum especificamente voltado para a inserção profissional das mulheres. O mais próximo é o inciso II que fala em "contribuir para a redução de desigualdades sociais e econômicas de mulheres" (BRASIL, 2011c). Os objetivos são:

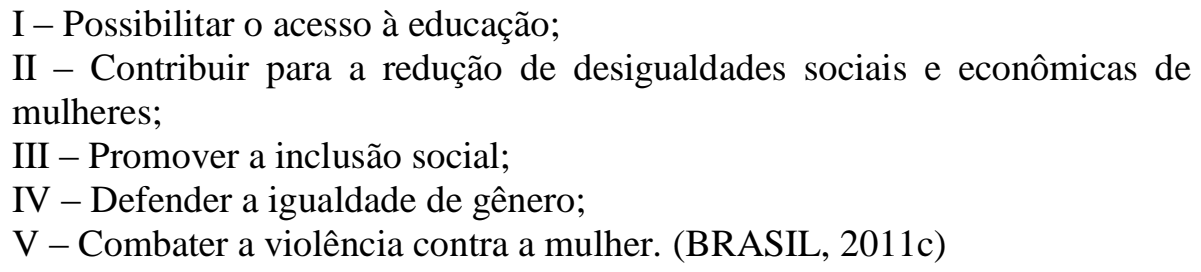

Os documentos do Programa não apresentam sempre a mesma orientação em relação aos objetivos do Mulheres Mil e alguns deles acabam se perdendo em relação ao foco que deve ser mantido. Ainda que em Brasil (2011b), encontra-se: "Mesmo que não leve à inserção no mundo do trabalho, o programa leva à uma noção de cidadania que invariavelmente leva a uma transformação social" (BRASIL, 2011b), dos dez objetivos do módulo Permanência e Êxito, listados no Guia Metodológico do Programa, cinco estão explicitamente relacionados ao ingresso e/ou permanência no mundo do trabalho (grifados abaixo):

Os principais objetivos do Módulo de Permanência e Êxito são:

- facilitar a permanência da população-alvo, minimizando as possibilidades de baixo rendimento e/ou desistência;

- propiciar um ambiente amigável e acolhedor que aumente as chances de desempenho e de êxito das alunas;

- dar suporte, em forma de serviços e espaços, às mulheres alunas do Programa para que elas resgatem sua segurança e sintam confiança na equipe multidisciplinar e na instituição;

- promover o aconselhamento das educandas, por meio de serviços de assistência e apoio;

- orientar as alunas para superação das dificuldades inerentes ao processo de inclusão e permanência na instituição e no mundo do trabalho;

- cuidar para que o ambiente e as pessoas acolham e respeitem as mulheres do Programa, aumentando assim sua autoestima; 
- capacitar as educandas para a compreensão e o exercício da economia solidária, do empreendedorismo, do cooperativismo e do associativismo como oportunidades de geração de renda e de melhor desempenho no mundo produtivo;

- qualificar as educandas quanto à postura profissional requerida no mundo do trabalho;

- viabilizar e firmar parcerias com instituições públicas e privadas para possibilitar a inserção das egressas no mundo de trabalho;

- acompanhar e monitorar as educandas nos estágios e no desempenho profissional, de modo a agir sempre que necessário para preservar e melhorar sua posição no mundo do trabalho. (BRASIL, 2012b, grifo nosso)

Os objetivos do módulo Permanência e Êxito não conferem com aqueles listados na Portaria que institui o Programa, detalhados mais anteriormente. Desta forma, os objetivos que devem ser buscados precisam ser melhor definidos nos documentos institucionais, bem como o conceito de "êxito".

Não se nega a importância da inserção profissional das mulheres e nem se acredita que a instituição ofertante deva se abster de oferecer todo o apoio necessário para tal. Contudo, os objetivos de Brasil (2011c) são mais tangíveis e fundamentais para o sucesso delas em qualquer área de suas vidas, inclusive a profissional. Antes de mais nada, o público feminino em situação de vulnerabilidade social precisa de oportunidade para acessar a educação, e essa educação deve promover autonomia, empoderamento e exercício de cidadania.

Sugere-se, aqui, que a documentação do Programa seja revista e alinhada dentro dos mesmos princípios norteadores, e que eles sejam tangíveis e muito claros, tanto para quem oferece o Programa (instituições, professores, assistentes sociais, entre outros) quanto para as mulheres atendidas.

Todas as colocações aqui trazidas têm o objetivo de contribuir positivamente com o Programa e para a ampliação do capital social das alunas. Entretanto, cabe, mais uma vez, reforçar alguns cuidados a serem tomados. No que diz respeito à família, em primeiro lugar, que estes aspectos não devem, de forma alguma, reforçar um perfil de mulher idealizada, naturalmente inclinada para os cuidados do lar, ou, ainda, colocar somente nas mulheres a responsabilidade pelos cuidados com a família e com a educação dos filhos. Relativamente à participação e à cidadania, a ampliação do capital social deve ser no sentido de garantir direitos e de habilitar as mulheres a participarem das decisões, sem, entretanto, que o Estado seja desresponsabilizado de sua obrigação de garantir a democracia. 


\section{CONSIDERAÇÕES FINAIS}

Esta pesquisa surgiu da vontade de investigar se o Programa Mulheres Mil do campus Taguatinga teve relevância no capital social das participantes e se influenciou suas vidas de alguma maneira. Para responder a isso, foram trazidas algumas abordagens de capital social que permitiram compreendê-lo, analisá-lo e contextualizá-lo com outros aspectos e conceitos. Nessa investigação, articulou-se capital social com outros capitais, como o econômico, humano e cultural, com a educação, com políticas públicas, com a família e com o papel da mulher na sociedade e na família. Nessa busca, deparou-se com alguns entendimentos contraditórios, o que permitiu fugir de armadilhas conceituais e visões unilaterais sobre os temas pesquisados.

A construção do referencial teórico, além de ampliar a compreensão sobre capital social e temas correlatos, também permitiu analisar o Programa Mulheres Mil com maior profundidade, servindo de guia de análise. Esta articulação conceitual foi decisiva para unir ideias, conceitos e compreender o arcabouço teórico sobre o tema da pesquisa, ampliando a compreensão sobre o problema.

Esta pesquisa se insere no campo da educação, e como tal, partiu da realidade e das relações sociais para compreender o universo investigado, sendo uma pesquisa qualitativa. Os procedimentos metodológicos permitiram operacionalizar os conceitos e investigar a questão com objetividade. $\mathrm{O}$ instrumento de coleta de dados utilizado foi entrevista, por meio de um roteiro semiestruturado. $\mathrm{O}$ roteiro foi elaborado dentro das categorias de análise preliminares definidas com base no referencial teórico.

A metodologia foi trabalhada de forma a comportar mudanças de percurso que pudessem ampliar a compreensão sobre o tema. Durante a condução das entrevistas, algumas perguntas foram modificadas, ampliadas e melhor esclarecidas, e, na fase de análise, foi necessário alterar as categorias conceituais para que melhor comportassem as evidências que surgiram nas entrevistas.

O referencial teórico, a articulação entre os conceitos e os procedimentos metodológicos adotados permitiram responder à questão da pesquisa e o alcance dos objetivos definidos. A análise das entrevistas foi conduzida pelas categorias conceituais relacionadas ao 
capital social: empoderamento, relações familiares, relações sociais, e participação e cidadania.

A questão central foi confirmada, o Programa teve influência positiva, ainda que em níveis diferentes, em todas as categorias de análise do capital social consideradas, o que permite afirmar que o Mulheres Mil do campus Taguatinga ampliou o capital social das participantes e se mostrou relevante em suas vidas, especialmente nas questões acerca de empoderamento e relações pessoais. Para as relações familiares, o Programa teve influência relevante, e nos aspectos ligados a participação e cidadania, se mostrou pouco relevante.

Um dos objetivos da pesquisa foi verificar se os objetivos do Programa foram alcançados. Neste sentido, é possível afirmar que, no campus Taguatinga, quatro dos cinco objetivos do Mulheres Mil foram alcançados. O curso oferecido possibilitou acesso à educação, contribuiu para a redução de desigualdades sociais e econômicas de mulheres, promoveu a inclusão social e defendeu a igualdade de gênero.

Surgiu, após as entrevistas, uma questão pertinente e que permanecerá sem resposta, pela sua complexidade, que é a baixa inserção profissional das alunas do curso de Artesanato com Resíduos Sólidos. Das sete alunas entrevistadas, somente duas desempenham atividade profissionalmente (que, inclusive, já desempenhavam antes) e uma começou a trabalhar, em outra área profissional. Duas delas utilizam as técnicas artesanais para outras finalidades, de forma eventual.

De qualquer forma, compreende-se que o Mulheres Mil do campus Taguatinga foi exitoso, pois o público feminino atendido pelo Programa necessita de oportunidades para acessar a educação, uma educação capaz de promover autonomia, empoderamento e exercício de cidadania. Isto foi, em grande medida, alcançado. Não se nega, entretanto, a importância da inserção destas mulheres no mundo do trabalho.

Outro objetivo desta pesquisa era trazer sugestões que pudessem contribuir para o Programa. Estas contribuições estão relacionadas com aspectos do capital social e outros que surgiram durante a execução do Programa, no decorrer da pesquisa e nas entrevistas com as alunas.

As proposições em relação ao capital social foram no sentido de criar meios de ampliar os mecanismos para sua formação, por meio do empoderamento, das relações sociais, 
relações familiares, e participação e cidadania. Sugere-se, também, que os documentos institucionais sejam avaliados, no sentido de clarear os objetivos do Programa, que são, às vezes, contraditórios dependendo da fonte consultada. Ademais, mostrou-se relevante trazer o questionamento relativo à exigência de $75 \%$ de presença para a certificação das alunas. Embora esta seja uma exigência legal, para o público em questão é algo bastante difícil de ser alcançado, e pode servir como um desestímulo à permanência. Também surgiram as contribuições das alunas no sentido de que o Programa deveria ter continuidade, tanto para abrigar novas mulheres, quanto para aprofundar o aprendizado daquelas que já frequentaram. Foi, ainda, reforçada a importância do lanche e da brinquedoteca.

As sugestões dadas para o Programa devem ter o objetivo de contribuir para a ampliação do capital social das alunas de forma positiva, e para tanto, é necessário ressaltar que a condução do Mulheres Mil deve ter o cuidado de não reforçar estereótipos relativos à família e à mulher, tampouco tirar do Estado sua responsabilidade de garantir democracia e espaços de participação. 


\section{REFERÊNCIAS}

ALMEIDA, E. P.; PEREIRA, R. S. Críticas à teoria do capital humano: uma contribuição à análise de políticas públicas em educação. Revista de Educação, v. 9, n. 15, 2000. Disponível em:

<http://www.ufmt.br/revista/arquivo/rev15/AlmeidaPereira.html>. Acesso em: 19 fev. 2014.

ALVES, Fátima. et al. Os efeitos das diferentes formas de capital no desempenho escolar: um estudo à luz de Bourdieu e de Coleman. Revista Brasileira de Educação, v. 15, n. 45, set./dez. 2010. Disponível em <http://www.scielo.br/pdf/rbedu/v15n45/07.pdf>. Acesso em: 19 mai. 2014.

ANTUNES, Elisandro Rodrigo. et al. Desenvolvimento, Capital Social e Educação no Brasil. In: III Seminário do Centro de Ciências Sociais Aplicadas, Cascavel, out. 2004. Disponível em: http://www.unioeste.br/campi/cascavel/ccsa/IIISeminario/artigos/Artigo\%2011.pdf >. Acesso em: 19 mai. 2014.

AQUINO, J. A. As teorias da ação social de Coleman e de Bourdieu. Humanidades e Ciências Sociais, Fortaleza, Universidade Estadual do Ceará, v. 2, n.2, p.13-27, 2000. Disponível em <http://www.lepem.ufc.br/jaa/2teorias.pdf >. Acesso em 04 jan. 2016.

BAQUERO, M. Alcances e Limites do capital social na construção democrática. In: BAQUERO, M. (Org.) Reinventando a sociedade na América Latina: cultura política, gênero, exclusão e capital social. Porto Alegre: Editora Universidade UFRGS, 2001a. p.19-49.

Capital social na América Latina. In: BAQUERO, M. (Org.) Reinventando a sociedade na América Latina: cultura política, gênero, exclusão e capital social. Porto Alegre: Editora Universidade UFRGS, 2001b, p.50-70.

BAQUERO, M.; BAQUERO, R. Capital social e empoderamento no desenvolvimento social: um estudo com jovens. Sociedade em Debate, Pelotas, v. 13, n. 1, p.47-64, jan./jun. 2007. Disponível em < http://www.rsd.ucpel.tche.br/index.php/rsd/article/viewFile/412/366>. Acesso em: 19 mai. 2014.

BILAC, Elisabete Dória. Gênero, vulnerabilidade das famílias e capital social: algumas reflexões. In: CUNHA, José. M. P. (Org.). Novas metrópoles paulistas: população, vulnerabilidade e segregação. Campinas: Nepo/Unicamp, 2006. p.51-65.

BOURDIEU, P. A escola conservadora: as desigualdades frente à escola e à cultura. 1966. In: Escritos de educação. Petrópolis: Editora Vozes, 2011a. p.39-64.

O capital social: notas provisórias. 1980. In: . Escritos de educação. Petrópolis: Editora Vozes, 2011b. p.65-70.

. Os três estados do capital cultural. 1979. In: BOURDIEU, P. Escritos de educação. Petrópolis: Editora Vozes, 2011c. p.65-70.

The forms of capital. In: RICHARDSON, J. (Org.). Handbook of theory and research for the sociology of education. Nova Iorque: Greenwood Press, 1986. p.241-258

BRASIL. Ministério da Educação. Chamada Pública MEC/SETEC - 001/2012: Programa Mulheres Mil - Educação, Cidadania e Desenvolvimento Sustentável. Documento de Referência para Apresentação e Seleção de Projetos. Brasília, DF, 2012a. 14 p. Disponível em: 
$<$ http://portal.mec.gov.br/index.php?option=com_docman\&task=doc_download\&gid=10384\&Itemid= >. Acesso em: 20 fev. 2014.

Ministério da Educação. Mulheres Mil: do sonho à realidade. Organização: Stela Rosa. Brasília, DF, 2011a.

Ministério da Educação. Portaria Normativa no 7, de 22 de junho de 2009. Dispõe sobre o mestrado profissional no âmbito da Fundação Coordenação de Aperfeiçoamento de Pessoal de Nível Superior - CAPES, Diário Oficial da União. Brasília, DF, 2009. Disponível em: < https://www.capes.gov.br/images/stories/download/legislacao/Revogada-Portaria-Normativa-n_7-22de-junho-2009-Mestrado-Profissional.pdf>. Acesso em: 10 mar. 2016.

Ministério da Educação. Mulheres Mil Educação, Cidadania e Desenvolvimento Sustentável: guia metodológico do Sistema de Acesso, Permanência e Êxito. Brasília, DF, 2012b. 48p. Disponível em <http://portal.mec.gov.br/index.php?option=com_docman\&task=doc_download \& gid=11834\&Itemid=>. Acesso em: 20 fev. 2014.

Ministério da Educação. Programa Nacional Mulheres Mil Educação, Cidadania e Desenvolvimento Sustentável. Brasília, DF, 2011b. 20 p. Disponível em $<$ http://portal.mec.gov.br/index.php?option=com_docman\&task=doc_download\&gid=8598\&Itemid= >. Acesso em: 20 fev. 2014.

Portaria $\mathrm{n}^{\mathrm{o}} 1.015$, de 21 de julho de 2011. Institui o Programa Nacional Mulheres Mil. Diário Oficial da União. Brasília, DF, 22 jul. 2011c. Disponível em: $<$ http://pesquisa.in.gov.br/imprensa/jsp/visualiza/index.jsp?jornal=1\&pagina=38\&data=22/07/2011>. Acesso em: 20 fev. 2014.

Mulheres comandam 40\% dos lares brasileiros. Portal Brasil, Brasília, 08 mai. 2015. Disponível em http://www.brasil.gov.br/cidadania-e-justica/2015/05/mulheres-comandam-40-doslares-brasileiros, acesso em 22 jan. 2016.

COLEMAN, J. Social capital in the creation of human capital, American Journal of Sociology, v. 94, 1988. Suplemento: Organizations and Institutions: Sociological and Economic Approaches to the Analysis of Social Structure, p.S95-S120.

CRESWELL, J. W. Projeto de Pesquisa: métodos qualitativo, quantitativo e misto. Tradução: Magda França Lopes. 3.ed. Porto Alegre: Artmed, 2010.

DEMO, P. Educação e Desenvolvimento: análise crítica de uma relação quase sempre fantasiosa. 1999. Disponível em <http://www.senac.br/informativo/bts/251/boltec251b.htm>. Acesso em: 06 fev. 2014.

DESLANDES, S. F. A construção do projeto de pesquisa. In: MINAYO, M. C. S. (Org.). Pesquisa social: teoria, método e criatividade. 18. ed. Petrópolis, RJ: Vozes, 1994.

DUARTE, R. Entrevistas em pesquisa qualitativa. Educar em revista. Curitiba: UFPR, 2004. p.213225.

Pesquisa qualitativa: reflexões sobre o trabalho de campo. Cadernos de Pesquisa, São Paulo, n. 115, p.139-154, mar. 2002. Disponível em: <http://educa.fcc.org.br/scielo.php?script=sci_ abstract\&pid=S0100-15742002000100005\&lng=pt\&nrm=iso\&tlng=pt $>$. Acesso em: 19 abr. 2014.

FONSECA, C. Olhares antropológicos sobre a família contemporânea: da família ao parentesco em sociedades complexas. Participação na Mesa Redonda "O lugar da família na ciência contemporânea: 
desafios e tendências na pesquisa". Congresso Internacional Pesquisando a Família, Florianópolis, abril, 2002.

GAMBOA, S. S. Pesquisa em Educação: métodos e epistemologias. Campinas: s.n., 2006. Disponível em: 〈www.geocities.ws/grupoepisteduc/arquivos/livrogamboa.doc〉. Acesso em 15 jan. 2016.

GIROLAMI, M. C. Educação e trabalho: um olhar dos jovens de baixa renda do Brasil e da Argentina. 2014. 245 f. Tese (Doutorado em Ciências Sociais) - Centro de Pós-graduação das Américas - CEPPAC da Universidade de Brasília, Brasília, 2014.

GOMES, R. A análise de dados em pesquisa qualitativa. In: MINAYO, M. C. S. (Org.). Pesquisa social: teoria, método e criatividade. 18. ed. Petrópolis, RJ: Vozes, 1994.

HOFLING, E. M. Estado e Políticas (Públicas) Sociais. Cadernos Cedes, ano XXI, n. 55, nov. 2001. Disponível em <http://www.scielo.br/scielo.php?script=sci_arttext\&pid=S010132622001000300003\&lng=en\&nrm=iso>. Acesso em: 01 mai. 2014.

KERLINGER, F. N. Metodologia de Pesquisa em Ciências Sociais: um tratamento conceitual. São Paulo: EPU, 1979.

MORROW, Virginia. Conceituando o capital social em relação a crianças e jovens: é diferente para meninas? Cadernos Cedes, vol. 28, n. 101, p.1351-1373, set./dez. 2007. Disponível em <http://www.scielo.br/pdf/es/v28n101/a0528101.pdf〉. Acesso em: 19 mai. 2014.

PRÁ, Jussara Reis. Cidadania de Gênero, capital social, empoderamento e políticas públicas no Brasil. In: BAQUERO, M. (Org.). Reinventando a sociedade na América Latina: cultura política, gênero, exclusão e capital social. Porto Alegre: Editora Universidade UFRGS, 2001. p.173-208.

REAY, Diane. A Silent Majority?: mothers in parental involvement. Women's Studies International Forum, EUA, Ed. Elsevier Science Ltd, v. 18, n.3, p.337-348, 1995.

Gendering Bourdieu's concepts of capitals?: emotional capital, women and social class.

The Sociological Review, Oxford, RU; Malden, EUA, v.52, Issue Supplement s2, p.57-74, out. 2004.

SANTOS, Tânia Steren. Gênero e políticas sociais: novos condicionamentos sobre a estrutura familiar. SER Social, Brasília, v. 10, n. 22, p.97-128, jan./jun. 2008.

SCHMIDT, João Pedro. Equilíbrio de baixa intensidade: capital social e socialização política dos jovens brasileiros na virada do século. In: BAQUERO, M. (Org.). Reinventando a sociedade na América Latina: cultura política, gênero, exclusão e capital social. Porto Alegre: Editora Universidade UFRGS, 2001. p.119-149.

SILVEIRA, Angelita Fialho. Capital Social e Educação: perspectivas sobre empoderamento da juventude em Porto Alegre. 2005. 114 f. Dissertação (Ciência Política) - Instituto de Filosofia e Ciências Humanas da Universidade Federal do Rio Grande do Sul, Porto Alegre, 2005.

ZAGO, N. Quando os dados contrariam as previsões estatísticas: os casos de êxito escolar nas camadas socialmente desfavorecidas. Paidéia, Ribeirão Preto, FFCLRP-USP, p.70-80, jan./jul.2000.

. Realidades sociais e escolares e dinâmica familiar nos meios populares. Paidéia, Ribeirão Preto, FFCLRP-USP, p.63-73, fev./ago.1988. 


\section{ANEXO A - Roteiro de entrevista}

\begin{tabular}{|c|c|c|c|}
\hline \multicolumn{4}{|l|}{ Nome: } \\
\hline \multicolumn{3}{|l|}{ Ocupação: } & Telefones: \\
\hline Escolaridade: & \multicolumn{3}{|c|}{ Idade: } \\
\hline \multicolumn{4}{|c|}{ Situação familiar (solteira, casada...): } \\
\hline Qtd. Filhos: & \multicolumn{3}{|c|}{ Idade filhos: } \\
\hline \multicolumn{4}{|c|}{ Séries dos filhos: } \\
\hline \multicolumn{4}{|c|}{ Residência (própria ou alugada): } \\
\hline \multicolumn{4}{|c|}{ Quantas pessoas moram na residência: } \\
\hline Data: & Início: & Término: & Local: \\
\hline \multicolumn{4}{|c|}{$\begin{array}{l}\text { Orientações gerais para antes do início: } \\
\text { - Agradecer a participação; } \\
\text { - Falar o motivo da entrevista e enfatizar a importância do depoimento da aluna neste trabalho; } \\
\text { - Informar que todos os depoimentos serão anônimos e para fins de pesquisa; } \\
\text { - Explicar como a entrevista será conduzida, de forma a comparar antes e depois do curso; } \\
\text { - Informar o tempo máximo de duração esperado }(1 \mathrm{~h}) \text {; } \\
\text { - Pedir autorização para gravar; } \\
\text { - Evitar aprovar ou negar com gestos, com a cabeça ou verbalmente; } \\
\text { - Evitar completar frases; } \\
\text { - Anotar o gestual e expressões de emoção; } \\
\text { - Caso a entrevistada não entenda a pergunta, leia uma vez mais. Se ainda assim houver dúvida, } \\
\text { - explique a questão com outras palavras. } \\
\text { Perguntar se pode entrar em contato para elucidar novas questões ou questões que não ficaram } \\
\text { claras. }\end{array}$} \\
\hline \multicolumn{4}{|c|}{ SOBRE O PROGRAMA MULHERES MIL } \\
\hline \multicolumn{4}{|c|}{$\begin{array}{l}\text { - Fale um pouco sobre sua participação no Programa Mulheres Mil. } \\
\text { - Quais os pontos fortes e fracos do curso? } \\
\text { - De qual matéria (ou professor) você mais gostou? } \\
\text { - O que você mudaria no Programa Mulheres Mil para que ele ficasse melhor? }\end{array}$} \\
\hline \multicolumn{4}{|c|}{ CATEGORIA “CONFIANÇA” } \\
\hline \multicolumn{4}{|c|}{$\begin{array}{l}\text { - Como você avalia sua confiança nas pessoas da sua família antes do curso? E depois? } \\
\text { - Como você avalia sua confiança nas pessoas e grupos fora sua família antes do curso? E depois? }\end{array}$} \\
\hline \multicolumn{4}{|c|}{ CATEGORIA “PARTICIPAÇÃO (COOPERAÇÃO) E CIDADANIA” } \\
\hline \multicolumn{4}{|c|}{$\begin{array}{l}\text { - Você frequentava algum grupo antes do curso (atividades culturais ou esportivas, associações, } \\
\text { cooperativas, grupos religiosos, sindicatos, partidos, etc.)? Passou a frequentar depois? } \\
\text { - Você participava de eventos ligados ao bem estar da sua comunidade e de participação política? E } \\
\text { depois? }\end{array}$} \\
\hline
\end{tabular}




\section{CATEGORIA “RELAÇõES FAMILIARES"}

- Fale um pouco sobre suas relações familiares antes e depois do curso.

- Como sua decisão de participar do Programa foi recebida pela sua família? Como você acha que seria hoje?

- Você se sentia valorizada pela sua família, pelas suas atividades profissionais, pela sua dedicação à família e filhos, pelo seu envolvimento com as tarefas da casa ou outros? E hoje?

\section{CATEGORIA “ENVOLVIMENTO COM A EDUCAÇÃO DOS FILHOS"}

- Fale um pouco sobre como era sua participação na educação e envolvimento nas atividades da escola do(s) seu(s) filho(s) e como está agora.

- Existia diferença na sua participação na educação do(s) seu(s) filho(s) e a participação do pai dele(s)? E hoje?

- Antes do curso, o que você achava que determinaria o sucesso do(s) seu(s) filho(s) no futuro? E depois do curso, o que você acha?

- Quais os valores que você achava importante passar para os seu(s) filho(s)? E agora?

\section{CATEGORIA “EMPODERAMENTO”}

- Você achava que por ser mulher tinha oportunidades e tratamento diferentes? E hoje?

- Você acha que você e sua forma de ver o mundo mudaram depois de participar do Programa? Como?

- Você se sente capaz de realizar coisas hoje que não se sentia capaz antes? Cite exemplos. 


\title{
ANEXO B - Transcrições das entrevistas
}

\author{
Carolina
}

\begin{tabular}{|c|c|}
\hline Suzana: & $\begin{array}{l}\text { Então, eu queria que você falasse um pouco, Carolina, sobre a sua participação no Programa } \\
\text { Mulheres Mil. }\end{array}$ \\
\hline Carolina: & $\begin{array}{l}\text { A minha participação no Mulheres Mil foi numa fase da minha vida que eu tava em situação de } \\
\text { vulnerabilidade, onde eu morava numa invasão, na rua, né, no caso. Em busca, claro, da minha } \\
\text { moradia. E onde eu morava dentro de um barraco de madeira. Um lugar onde não tinha banheiro, } \\
\text { um lugar que, que não tinha luz. Claro que a gente pegava como gambiarra. A água também era } \\
\text { gambiarra. Então, veio numa situação de, realmente, uma situação de que eu estava mesmo } \\
\text { precisando pela minha autoestima estar afetada. Pelo desenvolver dos dias que estavam sendo } \\
\text { cansativos, que estavam sendo sofridos na invasão. Então, realmente veio como um refúgio, veio } \\
\text { como uma esperança de vida, uma esperança de dias melhores. E a partir do Mulheres Mil que eu } \\
\text { voltei a sonhar, eu voltei a buscar melhorias, eu voltei a, realmente, a ter um convívio de amizade. } \\
\text { Um lugar que tinha mulheres realmente que tinha força de vontade. Histórias maravilhosas pra } \\
\text { contar. Então foi, realmente, um convívio que eu tive lá, foi de superação. }\end{array}$ \\
\hline Suzana: & $\begin{array}{l}\text { Carolina, me fala, por favor, quais são os pontos fortes e fracos do curso que você fez no Mulheres } \\
\text { Mil. }\end{array}$ \\
\hline Carolina: & $\begin{array}{l}\text { Os pontos forte foi, realmente, é... é, escutar, ouvir, vivenciar histórias de... de superação dentro } \\
\text { do curso, realmente, das mulheres que estavam lá. E... e, realmente, dos outros cursos, dos } \\
\text { professores também que foram sempre super atenciosos. E, realmente, o ponto fraco eu vejo } \\
\text { como... pra falar a verdade eu nem tenho, nem penso em ponto fraco porque, pra mim, do começo } \\
\text { ao fim só teve é... foi uma grande ajuda mesmo. Por que, realmente, eu cheguei lá eu estava super } \\
\text { desanimada com a vida. Eu não via, realmente... é... eu não via... eu não tinha esperança pro } \\
\text { futuro. Eu não via como pudesse sair daquela situação. Então, isso... é... eu não vejo como ponto } \\
\text { fraco não. Pra mim, realmente, só teve pontos positivos. }\end{array}$ \\
\hline Suzana: & Carolina, de qual matéria ou de qual professor você mais gostou? \\
\hline Carolina: & $\begin{array}{l}\text { As matéria, assim, vai ser difícil eu lembrar dos, dos nomes, né, por que já tem um tempinho. } \\
\text { Agora, só que, assim, pra mim teve o... em relação ao artesanato foi muito bom. Foi um } \\
\text { aprendizado muito grande e a gente vê que nos dias - dias a gente pode reaproveitar, né. Tudo que } \\
\text { tá a nossa disposição a gente pode reaproveitar. E, e agora, por exemplo: Suzana Guerra foi uma } \\
\text { professora excelente, mesmo. Gostei muito. E, agora teve um professor lá que ficou inesquecível, } \\
\text { só que eu não sei o nome dele. Acho que é seu irmão, né? }\end{array}$ \\
\hline Suzana: & Guilherme. \\
\hline Carolina: & $\begin{array}{l}\text { O Guilherme, pois é. Então, foi uma das aulas que mais chamaram a nossa atenção, foi mais } \\
\text { divertidas. }\end{array}$ \\
\hline Suzana: & Carolina, o que você mudaria no programa Mulheres Mil para que ele ficasse melhor? \\
\hline Carolina: & $\begin{array}{l}\text { Hum... Difícil a pergunta... ((risos)). Mas o que eu mudaria, assim, é... pra, realmente, pra ter todos } \\
\text { os anos. Buscar novas histórias de outras mulheres. Buscar reconhecimento né, de outro convívio, } \\
\text { né. Buscar mulheres que, realmente, pode ajudar, pode influenciar. Então, todos os anos, } \\
\text { realmente, poderia ter outras mulheres mesmo, buscar outras mulheres, para ver outras histórias, } \\
\text { pra conhecer outras histórias. Eu acho que o Mulheres Mil é... não podia ter se encerrado somente } \\
\text { naquele ano, mas poderia ter dado continuidade. }\end{array}$ \\
\hline Suzana: & $\begin{array}{l}\text { Carolina, como você avalia a sua confiança nas pessoas da sua família antes do curso e depois? } \\
\text { Mudou alguma coisa na confiança que você tem na sua família antes e depois do curso? }\end{array}$ \\
\hline Carolina: & $\begin{array}{l}\text { Sim, claro, com certeza mudou. É... particularmente, a gente, é... no curso Mulheres Mil, a gente } \\
\text { tinha o auxílio, ali, de poder levar os nossos filhos a estar juntos ali numa brinquedoteca enquanto } \\
\text { a gente podia tá fazendo o curso. E veio uma despreocupação. A gente não tinha tanta } \\
\text { preocupação de deixar em outro lugar, em outra casa ou com outra pessoa. Então, assim, a partir } \\
\text { daí a confiança no meio familiar foi bom. Por que, igual eu tava dizendo, é... querendo ou não eu } \\
\text { estava numa situação, junto com a minha família, de... é... sem esperança nenhuma. Então, a partir }\end{array}$ \\
\hline
\end{tabular}




\begin{tabular}{|c|c|}
\hline & $\begin{array}{l}\text { do curso, depois que eu me animei, depois que eu me restabeleci, a, a minha força voltou; voltei a } \\
\text { ter força, voltei a ter sonhos. Então, é... a minha família passou a viver o que eu tava vivendo } \\
\text { naquele momento. Então, foi muito gratificante, foi muito proveitoso porque não só eu saí } \\
\text { ganhando, mas sim, os meus filhos, por estarem ali perto de mim, estar brincando quando, né... ali, } \\
\text { próximo da gente. E o meu esposo também, né, porque ele via que, depois do curso, de alguma } \\
\text { forma, eu, é... fiquei mais animada, comecei a ficar mais alegre, eu via como... como os dias de ir } \\
\text { pro curso, dias mais gratificantes. Então, quando eu voltava, realmente, eu voltava como uma } \\
\text { pessoa mais renovada. }\end{array}$ \\
\hline Suzana: & $\begin{array}{l}\text { E como você avalia a sua confiança nas pessoas e grupos, fora da sua família, antes do curso e } \\
\text { depois? Assim, se a sua confiança nas pessoas, nos grupos, sem serem da sua família, mudou: } \\
\text { antes, era uma coisa antes do curso e depois? Mudou? Como era? }\end{array}$ \\
\hline Carolina: & $\begin{array}{l}\text { Eu acho, assim. Eu era uma pessoa, realmente, é... não vou falar que eu mudei totalmente, mas eu } \\
\text { continuo num processo de mudança a cada dia. Que... Eu já vim, de berço, de uma pessoa não de } \\
\text { ter muitas amizades. Não de ter um, um... é... muitos, muitos colegas. Fui uma pessoa que... que } \\
\text { tive que, realmente, amadurecer muito cedo. Então, é... a partir do momento que, é... depois que a } \\
\text { gente fez o curso, daquele... claro que tem mulheres do Mulheres Mil que a gente tem contato, } \\
\text { que eu tenho contato até hoje, claro, por facebook, outros por falar; mora perto de mim. É... } \\
\text { então, assim, eu vi que, realmente, é... é... eu pude colocar as minhas dificuldades, colocar os meus } \\
\text { desejos, pra outras pessoas ouvir. Então, eu senti uma confiança. E, realmente, as pessoas } \\
\text { começaram a me ver de outros olhos porque elas passaram a me ouvir melhor e a me entender a } \\
\text { situação que eu tô vivendo. Então, depois disso, é... o meu ciclo de amizade aumentou. O meu } \\
\text { convívio com as pessoas aumentou. }\end{array}$ \\
\hline Suzana: & $\begin{array}{l}\text { Você frequentava algum grupo antes do curso? Assim: atividades culturais ou esportivas, } \\
\text { associações, cooperativas, grupos religiosos, sindicatos, partidos, etc.? Passou a frequentar depois? }\end{array}$ \\
\hline Carolina: & $\begin{array}{l}\text { Não. Eu não participava de nenhum grupo, é... e agora, hoje eu participo de grupos, é... na Igreja, } \\
\text { né? Na Igreja, eu faço parte de alguns grupos. E... é... depois também, é... a gente teve uma } \\
\text { relação... é... de busca por melhorias pra comunidade da gente. Então, a gente foi em busca de } \\
\text { reuniões entre os governos e, ali, a gente soube expressar, realmente, o que a gente tava } \\
\text { pretendendo, estando morando na invasão. E hoje eu vou começar a participar de uma associação } \\
\text { dentro do condomínio que eu moro. Então, assim, hoje eu tô vendo em outros grupos. Agora eu tô, } \\
\text { é... fazendo parte de outros grupos. }\end{array}$ \\
\hline Suzana: & $\begin{array}{l}\text { Certo... Você participava de eventos ligados ao bem estar da sua comunidade e de participação } \\
\text { política antes? E depois? }\end{array}$ \\
\hline Carolina: & $\begin{array}{l}\text { Sim, a gente... os eventos que a gente participa era que... a gente... É... Junto na comunidade onde } \\
\text { eu morava, a gente ia pra conferências, né, do governo. Todas as vezes que a gente via que de } \\
\text { alguma forma a gente podia mostrar o nosso convívio dentro da comunidade, a gente tava } \\
\text { participando de conferências e de reuniões também. Isso foi quando estava e depois. }\end{array}$ \\
\hline Suzana: & $\begin{array}{l}\text { Fale um pouco das suas relações familiares antes e depois do curso? Você já falou um pouquinho, } \\
\text { mas fala um pouco mais sobre isso. }\end{array}$ \\
\hline Carolina: & $\begin{array}{l}\text { É... Em relação aos familiares eu acho que... é... realmente, melhorou bastante. Porque... é... claro } \\
\text { que, vêm as dificuldades; a gente acha que vai se afastar, a gente acha que vai é... distanciar da } \\
\text { família, mas eu vi que teve pontos que veio a acatar na minha família que, realmente, a gente se } \\
\text { ajuntou; ganhamos força. E hoje, graças a Deus, a gente é uma família bem unida. }\end{array}$ \\
\hline Suzana: & $\begin{array}{l}\text { Como sua decisão de participar do programa foi recebida pela sua família? E como você acha que a } \\
\text { mesma decisão, hoje, seria recebida? }\end{array}$ \\
\hline Carolina: & $\begin{array}{l}\text { É... Assim... Acho que, quando veio o Mulheres Mil, veio como se... veio pra ajudar muito, né? } \\
\text { Então, se viesse hoje, eu com certeza entraria, e com certeza eu continuaria e a minha família } \\
\text { apoiaria. }\end{array}$ \\
\hline Suzana: & E a sua família apoiou? \\
\hline Carolina: & Sim. \\
\hline Suzana: & Lá em 2013 também? \\
\hline Carolina: & Sim. \\
\hline Suzana: & $\begin{array}{l}\text { Você se sentia valorizada pela sua família? Pelas suas atividades profissionais? Pela sua dedicação à } \\
\text { família e filhos? Pelo seu envolvimento com as tarefas da casa ou outras tarefas antes do curso? E }\end{array}$ \\
\hline
\end{tabular}




\begin{tabular}{|c|c|}
\hline & hoje, você se sente valorizada pelo que você faz? \\
\hline Carolina: & $\begin{array}{l}\text { É... Hoje, hoje eu vejo que eu me sinto mais valorizada. A gente, é... querendo ou não, hoje eu } \\
\text { tenho um convívio melhor com a minha família. E... veio... em relação à família, o esposo, é... os } \\
\text { meus filhos me valorizou muito, né? Me valorizou a partir... Acho que depois do curso continua me } \\
\text { valorizando porque viu que eu tenho potencial e que eu posso melhorar realmente, mais. }\end{array}$ \\
\hline Suzana: & $\begin{array}{l}\text { Fale um pouco sobre como era a sua participação na educação e envolvimento nas atividades da } \\
\text { escola dos seus filhos, no caso do seu filho que tá na escola, e como está agora. }\end{array}$ \\
\hline Carolina: & $\begin{array}{l}\text { Eu sempre fui bem... é... sempre participei muito bem da vida escolar do meu filho, né. Sempre fui } \\
\text { bastante atenciosa. Quando, eu preciso... Sempre que eu precisei estar junto na escola, reunião, } \\
\text { tudo. Dentro de casa, também, em relação às tarefas dele, eu sempre auxilio. Então, assim, tudo } \\
\text { que é em relação a educação, eu sempre tento focar o máximo pra poder despertar nele } \\
\text { curiosidade, despertar um convívio melhor com ele. Hoje mesmo, em relação à educação, tudo... } \\
\text { Todos os meios que leva o meu filho a desenvolver uma capacidade melhor, eu tô fazendo de tudo } \\
\text { pra fazer com que ele cresça mais e mais e venha a buscar uma educação, um relacionamento } \\
\text { melhor. }\end{array}$ \\
\hline Suzana: & $\begin{array}{l}\text { É... Existia diferença entre a sua participação e a do pai do seu filho na educação antes da sua } \\
\text { participação do curso? Existe hoje? }\end{array}$ \\
\hline Carolina: & Do pai? \\
\hline Suzana: & $\begin{array}{l}\text { É. Assim, a sua participação e a do pai, na educação do seu filho. Antes do curso, tinha diferença? } \\
\text { Você participava mais, ele participava mais? E depois do curso, isso mudou? }\end{array}$ \\
\hline Carolina: & $\begin{array}{l}\text { Acho que, em relação o... assim, a diferença é porque, como eu fico mais em casa, então, a... o... } \\
\text { em relação a educação do filho, fica mais na minha responsabilidade. Mas claro que o pai quando } \\
\text { está em casa, ajuda da melhor forma possível. Agora, diferença, diferença, acho que continua a } \\
\text { mesma. Em relação a isso, não mudou nada. Sempre a gente teve uma ligação muito boa. }\end{array}$ \\
\hline Suzana: & $\begin{array}{l}\text { O que você achava antes do curso que determinaria o sucesso dos seus filhos no futuro? E depois } \\
\text { do curso, o que você acha que determina o sucesso dos seus filhos no futuro? }\end{array}$ \\
\hline Carolina: & $\begin{array}{l}\text { Ah... antes do curso, eu tinha um objetivo mais de olhar pra mim, né? Porque, até então, o meu } \\
\text { filho era pequeno e a minha menina tinha, tinha... era bebê. Tinha acabado... tinha meses, no caso. } \\
\text { Então, assim, é... a gente, é... eu via... hoje não, hoje depois do curso eu vi como a importância nos } \\
\text { estudos pra ele. A importância dele crescer na escola, até então profissionalmente pra ter uma vida } \\
\text { mais estabilizada, uma vida melhor, uma educação mais elevada. }\end{array}$ \\
\hline Suzana: & Quais os valores que você achava importante passar para o seu filho antes do curso? \\
\hline Carolina: & $\begin{array}{l}\text { É... os valores que eu achava era a união, né. Até hoje eu acho que a União, o respeito, a } \\
\text { humildade. Isso eu levo pra mim e repasso pra minha família inteira. Se a gente quer chegar a } \\
\text { algum lugar, a gente tem que ter essa base familiar. }\end{array}$ \\
\hline Suzana: & $\begin{array}{l}\text { Mudou depois do curso? Os seus valores que você acha importante passar para os seus filhos } \\
\text { mudaram depois do curso ou são os mesmos? }\end{array}$ \\
\hline Carolina: & Continuam os mesmos. \\
\hline Suzana: & $\begin{array}{l}\text { Você, antes do curso, achava que, por ser mulher, tinha oportunidades e tratamento diferentes? } \\
\text { Antes do curso você achava isso? }\end{array}$ \\
\hline Carolina: & $\begin{array}{l}\text { Eu acho... é... diferente... sim, claro, a sociedade em que a gente vive até hoje, nós mulheres somos } \\
\text { olhadas como diferente. Mas, depois do curso, eu vi que, quando a gente quer, a gente pode } \\
\text { chegar em qualquer lugar. Basta a gente querer, ter atitude, e persistir naquilo que uma hora dá } \\
\text { certo. }\end{array}$ \\
\hline Suzana: & $\begin{array}{l}\text { Você acha que, você mesma e a sua forma de ver o mundo, mudaram depois de participar do } \\
\text { Programa? Se sim, como mudaram? }\end{array}$ \\
\hline Carolina: & $\begin{array}{l}\text { Ah, com certeza. É... eu tive... é... depois do curso, e... até quando eu tava fazendo o curso, eu vi } \\
\text { que a história... tinha histórias de mulheres, de todas as mulheres particularmente; tinha histórias } \\
\text { bem fortes que a gente podia levar como... é... pra nós mesmos, como experiência de vida, pra um } \\
\text { aprendizado. E no curso a gente vê que, realmente, tinha mulheres que, naquele momento, tavam } \\
\text { sofrendo muito, chegando num ato de depressão muito forte. E no desenvolver, a gente viu que, } \\
\text { realmente, nós conseguimos mudar a visão pro mundo, a visão pros dias que a gente estava tendo, } \\
\text { né? Que a gente podia superar e a gente buscou a superação. Acho que todas as mulheres daquele } \\
\text { curso sentiu realizada, vendo o mundo de outra forma. O mundo que, realmente, mesmo em meio }\end{array}$ \\
\hline
\end{tabular}




\begin{tabular}{|l|l|}
\hline Suzana: & $\begin{array}{l}\text { às dificuldades, a gente pode ser transformadas. } \\
\text { Você se sente capaz de realizar coisas hoje que não se sentia capaz de realizar antes do curso? Se } \\
\text { sim, pode exemplificar? }\end{array}$ \\
\hline Carolina: & $\begin{array}{l}\text { ((risos)). Eu acho assim... é... meio... o mais focado, assim, que eu achei foi o meio artesanato. Que } \\
\text { a gente jogava tanta coisa fora e a gente vê que a gente pode reaproveitar muitas coisas. É... e a } \\
\text { gente começou a dar valor nas pequenas coisas, realmente. Eu comecei a dar valor naquela } \\
\text { coisinha que eu achava que era lixo e começava a jogar fora, eu vi que, realmente, eu podia } \\
\text { aproveitar. Claro que, é... hoje eu não trabalho com artesanato, mas, é... sempre quando tem festa } \\
\text { do meu filho, alguma coisa, eu sempre coloco alguma coisinha, né? Sempre reaproveito alguma } \\
\text { coisinha pra colocar, pra mexer, botar a mão na massa. Então, eu vi que no artesanato, a gente } \\
\text { tem, realmente, um campo muito amplo. Então, tem meios... tem todos os meios pra gente mexer, } \\
\text { pra gente criar. Então, de alguma forma ou de outra, a gente, como donas de casa, acaba criando, } \\
\text { acaba usando alguma coisa que, realmente, se fosse antes, a gente jogaria no lixo. }\end{array}$ \\
\hline
\end{tabular}

\section{Fátima}

\begin{tabular}{|c|c|}
\hline Suzana: & É... fale um pouco, Fátima, sobre a sua participação no Mulheres Mil. \\
\hline Fátima: & $\begin{array}{l}\text { Quando eu entrei aqui, tava até falando, né, que tava com saudade de vim ((risos)). Nossa, eu } \\
\text { adorava vir pra cá. Achava muito legal. É muito conhecimento, né, que eu adquiri através do } \\
\text { Mulheres Mil, né. A participação com as amigas... Conheci gente nova que, até hoje, tá no meu } \\
\text { círculo de amizades. E eu gostei muito de participar. }\end{array}$ \\
\hline Suzana: & Quais os pontos fortes e fracos do curso? \\
\hline Fátima: & $\begin{array}{l}\text { Ah, os fortes, eu acho, assim, as oficinas, né, de artesanato, que eu amo. Os passeio... Gostava } \\
\text { muito (d)aqueles passeio, né, pra conhecer coisa diferente, que eu moro aqui há tantos anos e não } \\
\text { conhecia e conheci através dos passeio, né, que teve nesse programa. Os fracos, realmente, quando } \\
\text { tinha mesmo aquele, sei lá, discordância de alguns aluno. Mas o resto achava muito bom. }\end{array}$ \\
\hline Suzana: & De qual matéria ou professor você mais gostou? \\
\hline Fátima: & $\begin{array}{l}\text { Eu, assim, não é porque tô fazendo a pesquisa agora, mas a coordenadora era primeiro lugar } \\
\text { ((risos)) }\end{array}$ \\
\hline Suzana: & $(($ risos $))$ \\
\hline Fátima: & $\begin{array}{l}\text { Eu achava dez. Eu gostei muito de vários, não me lembro agora o nome, mas teve vários que passou } \\
\text { lá. Sobre a saúde, eu gostei muito. Ichi, foi inúmeros, assim, que eu gostei bastante, mas eu não } \\
\text { lembro o nome, né, agora. Esse da saúde eu gostei muito. }\end{array}$ \\
\hline Suzana: & Você perdeu a primeira matéria, não foi? \\
\hline Fátima: & Foi \\
\hline Suzana: & O que você mudaria no Programa Mulheres Mil pra que ele ficasse melhor? \\
\hline Fátima: & Ah, que tivesse mais aula de artesanato. Com certeza. \\
\hline Suzana: & Você acha que você passou a confiar mais nas pessoas da sua família depois do curso? \\
\hline Fátima: & Confiar? \\
\hline Suzana: & Mudou a sua confiança, antes do curso e depois do curso, nas pessoas da sua família? \\
\hline Fátima: & Hum... não observei isso, não. \\
\hline Suzana: & E nas pessoas e grupos fora da sua família? \\
\hline Fátima: & $\begin{array}{l}\text { Hum... aaa, às vezes sim, às vezes não, né. Não sei, depende do grupo, assim, que eu teje integrado, } \\
\text { né? }\end{array}$ \\
\hline Suzana: & $\begin{array}{l}\text { Fátima, você frequentava algum grupo antes do curso? Por exemplo: atividades culturais ou } \\
\text { esportivas, associações, cooperativas, grupos religiosos, sindicatos... Passou a frequentar depois? }\end{array}$ \\
\hline Fátima: & $\begin{array}{l}\text { Antes, só a Igreja mesmo, né. Grupos religiosos eu já participava. E algumas oficinas de artesanato } \\
\text { também. Sempre que eu via, por aí, eu participei, também, de vários. }\end{array}$ \\
\hline Suzana: & Depois mudou alguma coisa? \\
\hline Fátima: & $\begin{array}{l}\text { Depois a gente continuou, né, com outros grupos que a gente procurou. E tô fazendo curso, outros } \\
\text { cursos também. Inclusive, até, tô dando aula nesse projeto, né, de... Uma terapia ocupacional, né, } \\
\text { que eu tô dando aula lá. Aprendendo coisas nova, também, que lá tem muitos outros cursos. Aí, eu } \\
\text { procuro aprender coisas nova lá também. Aí, tô entMarisada lá. }\end{array}$ \\
\hline
\end{tabular}




\begin{tabular}{|c|c|}
\hline Suzana: & $\begin{array}{l}\text { Você participava de eventos ligados ao bem-estar da sua comunidade e de participação política } \\
\text { antes do curso? E depois? }\end{array}$ \\
\hline Fátima: & É, não. Eu não participo muito desse tipo de evento, não. \\
\hline Suzana: & Fátima, fale um pouco das suas relações familiares antes e depois do curso. \\
\hline Fátima: & $\begin{array}{l}\text { Assim, da família não mudou muita coisa não. Assim, sempre, eles sabem que eu sou muito } \\
\text { enteressada com artesanato, né, então, depois do curso só fez acrescentar mais, né. E eles me } \\
\text { apoiam muito em relação a isso. Tranquilo, muito apoio. }\end{array}$ \\
\hline Suzana: & Como a sua decisão de participar do programa foi recebida pela sua família? \\
\hline Fátima: & $\begin{array}{l}\text { Ah, foi bem. Bem recebido. Porque eles gostam quando vê que eu tô fazendo algum curso, } \\
\text { participando de alguma coisa, assim, eles gostam e me apoiam. }\end{array}$ \\
\hline Suzana: & Como você acha que seria hoje? \\
\hline Fátima: & Ah, aí me apoiariam mais ainda, com certeza ((risos)). \\
\hline Suzana: & $\begin{array}{l}\text { Fátima, você se sentia valorizada pela sua família, pelas suas atividades profissionais, pela sua } \\
\text { dedicação à família e filhos, pelo seu envolvimento com as tarefas da casa e/ou outros? E hoje? }\end{array}$ \\
\hline Fátima: & Eu me sinto valorizada, sim. \\
\hline Suzana: & Antes e depois? \\
\hline Fátima: & Antes e depois \\
\hline Suzana: & $\begin{array}{l}\text { Fátima, fale um pouco sobre como era a sua participação na educação e envolvimento nas } \\
\text { atividades da escola dos seus filhos, e como está agora. No caso, do seu filho; }\end{array}$ \\
\hline Fátima: & Uhum \\
\hline Suzana: & Você tem um só, né, em idade escolar \\
\hline Fátima: & $\begin{array}{l}\text { É... É, tranquilo, assim, tanto antes do curso quanto agora eu sempre procuro apoiar ele no que ele } \\
\text { precisa pro estudo, né. Eu sempre tô lá, firme. Às vezes, até, pego no pé demais ((risos)). É assim. }\end{array}$ \\
\hline Suzana: & $\begin{array}{l}\text { Existia diferença na sua participação na educação dos seus filhos e a participação do pai deles? E } \\
\text { hoje? }\end{array}$ \\
\hline Fátima: & Se existe diferença? \\
\hline Suzana: & $\begin{array}{l}\text { Se, assim, se você e o seu esposo participam da educação, participavam da educação dos seus filhos } \\
\text { de forma igual ou diferente antes do curso e se isso mudou depois do curso. }\end{array}$ \\
\hline Fátima: & $\begin{array}{l}\text { Não, assim, sempre houve diferença, sim. Por que, assim, o meu esposo, ele sempre acha que, } \\
\text { sempre achou, né, assim, que eu tenho mais, como é que se diz, que eu tenho mais tempo pra doar } \\
\text { pra eles, pros filhos, pra educação, então ele nunca... Assim, ele se preocupa, sim, mas não tanto } \\
\text { quanto eu, assim, né. Eu fico mais, como é que fala, mais junto, mais preocupada, aquela coisa } \\
\text { ((risos)). Depois do curso, então, a gente aprendeu muita coisa aqui, né, que a gente passa também } \\
\text { pra vida pessoal, em casa, claro, né, em relação a família, os filhos. A gente aprendeu muita coisa } \\
\text { aqui que a gente acaba levando pra educação dos filhos também. }\end{array}$ \\
\hline Suzana: & $\begin{array}{l}\text { Antes do curso, o que você achava que determinaria o sucesso dos seus filhos no futuro? E depois } \\
\text { do curso? O que você acha que determinará o sucesso no futuro dos seus filhos? }\end{array}$ \\
\hline Fátima: & $\begin{array}{l}\text { Eu acho, assim, é, os valores da família também ((engasgou)). Desculpe. É, teve várias palestra, } \\
\text { também, que a gente aprendeu sobre os valores da família, né, então eu acho que isso passa a } \\
\text { gente a, como é que se diz, a pensar melhor, a raciocinar melhor nos valores da família, né, e tentar } \\
\text { levar isso pra dentro de casa, né. }\end{array}$ \\
\hline Suzana: & $\begin{array}{l}\text { Quais os valores que você achava importante passar pros seus filhos antes do curso e depois do } \\
\text { curso? }\end{array}$ \\
\hline Fátima: & $\begin{array}{l}\text { Os valores que eu acho mais importante, assim, sempre achei, é, assim, é o temor a Deus, né, em } \\
\text { primeiro lugar. Que eu aprendi isso em criança, então eu carrego isso comigo, né, a passar pros } \\
\text { meus filhos o amor a Deus, né, ao trabalho e, assim, ao próximo, né. Hoje eu dia eu vejo muito, } \\
\text { assim, você, é, valorizar mais o próximo. Olhar mais pro humano, né, o lado humano. Eu vejo muito } \\
\text { isso. }\end{array}$ \\
\hline Suzana: & Você acha que mudou de antes do curso e depois? Se manteve da mesma forma? \\
\hline Fátima: & $\begin{array}{l}\text { Não, nesse ponto aí eu continuo do mesmo jeito. Sempre pensei assim e, hoje em dia, depois do } \\
\text { curso, eu vejo, mais ainda, que precisa ser dessa forma, né? }\end{array}$ \\
\hline Suzana: & $\begin{array}{l}\text { Fátima, você acha, antes do curso, que, por ser mulher tinha oportunidades e tratamento } \\
\text { diferentes? E hoje, depois do curso? }\end{array}$ \\
\hline
\end{tabular}




\begin{tabular}{|c|c|}
\hline Fátima: & $\begin{array}{l}\text { É, antes a gente via muita diferença, eu via muita diferença, né. Depois do curso, aprendi também } \\
\text { que a gente tem direitos iguais, né. A gente aprendeu muito sobre os direito da mulher, né, aqui. } \\
\text { Teve muita palestra, né, falando sobre isso ((risos)). Esse assunto. Então a gente aprendeu coisas } \\
\text { que não sabia ainda a respeito desse direito da mulher, né, que agora a gente sabe que a gente } \\
\text { tem, né, muito direito que pode ser, pode buscar, né, que antes eu não sabia. }\end{array}$ \\
\hline Suzana: & $\begin{array}{l}\text { Você acha que você e a sua forma de ver o mundo mudaram depois de participar do programa? Se } \\
\text { sim, como? }\end{array}$ \\
\hline Fátima: & $\begin{array}{l}\text { Difícil é explicar, né? ((risos)). Mas, sim. Eu acho que sim. Depois dos conhecimento, né? Depois das } \\
\text { palestra, das coisa, assim, a gente vê o mundo já de outra maneira, né? (não) Saberia te explicar } \\
\text { agora, né. ((risos)) }\end{array}$ \\
\hline Suzana: & ((risos)) Você se sente capaz de realizar coisas, hoje, que não se sentia capaz de realizar antes? \\
\hline Fátima: & Sim. \\
\hline Suzana: & Por exemplo? \\
\hline Fátima: & $\begin{array}{l}\text { Por exemplo assumir uma oficina de artesanato como eu tô, como eu assumi agora, né? Antes eu } \\
\text { era, assim, mais tímida, mais recatada, e tal. Às vezes tinha vergonha até de conviver, de conversar, } \\
\text { de dialogar com as pessoas, né? E agora já tem mais um, mais essa abertura na minha vida. De, sei } \\
\text { lá, de me aproximar mais das pessoas, de poder ensinar o que eu aprendi, né? Me sinto mais segura } \\
\text { agora ((risos)). }\end{array}$ \\
\hline Suzana & Tem algo a acrescentar, Fátima? \\
\hline Fátima & $\begin{array}{l}\text { Tudo foi muito bom, né? Foi muito bom esse curso Mulheres Mil e eu gostaria que voltasse, né, } \\
\text { esse curso pra cá pra gente poder fazer mais artesanato, né? Se tiver, com certeza, eu estarei aqui, } \\
\text { pra aprender a fazer muito mais coisa aqui. }\end{array}$ \\
\hline
\end{tabular}

\section{Janete}

\begin{tabular}{|c|c|}
\hline Suzana: & Fale um pouco sobre a sua participação no Programa Mulheres Mil. \\
\hline Janete: & $\begin{array}{l}\text { Bom, pra mim foi muito bom. Por que, eu era, assim, tímida. Depois do Mulheres Mil, sabe, passei a } \\
\text { conversar mais. Agora, falo até demais, converso tudo. Foi muito, foi um curso maravilhoso pra mim. }\end{array}$ \\
\hline Suzana: & Quais os pontos fortes e fracos do curso? \\
\hline Janete: & $\begin{array}{l}\text { Não, os fortes era quando tinha as oficina, né, os passeio. Já os fraco, o fraco pra mim era só aquela } \\
\text { questão do lanche, mas também era por causa das mulheres...((risos)) (Janete) }\end{array}$ \\
\hline Suzana: & De qual matéria ou professor você mais gostou? \\
\hline Janete: & Ah, com certeza, de quem? Da coordenadora, né? Que que cê acha? ((risos)) \\
\hline Suzana: & O que você mudaria no Programa Mulheres Mil pra que ele ficasse melhor? \\
\hline Janete: & Não... Não sei nem dizer. Era uma vez por semana, né? Duas vez, não era? \\
\hline Suzana: & É, às vezes tinha aula aos sábados. \\
\hline Janete: & Eh, eu botaria mais dias... Eu digo assim, três vez por semana, quatro. Aumentaria mais... \\
\hline Suzana: & Eh, Janete, como você avalia a sua confiança nas pessoas da sua família antes do curso e depois? \\
\hline Janete: & Não, pra mim tá a merma coisa. Eu confiava nelas e agora confio melhor ainda. \\
\hline Suzana: & E nas pessoas e grupos fora da sua família, antes do curso e depois do curso? \\
\hline Janete: & Também continua igual. \\
\hline Suzana: & Você frequentava algum grupo antes do curso? \\
\hline Janete: & Não. \\
\hline Suzana: & Por exemplo: atividades culturais, esportivas, associações, cooperativas. \\
\hline Janete: & Ah, eu tinha um... \\
\hline Suzana: & Grupos religiosos, sindicatos, partidos... Passou a frequentar depois? \\
\hline Janete: & $\begin{array}{l}\text { Não, eu tinha um que eu frequentava. Fazia um curso de papel machê. Acho que era até um } \\
\text { candidato que dava, na trinta e... trinta e seis. }\end{array}$ \\
\hline Suzana: & E depois do curso, você passou a frequentar algum outro grupo? \\
\hline Janete: & Sim, sim, a gente dava, eu tô dando um curso de... Na Igreja Presbiteriana, né. Aí tá muito bom. \\
\hline Suzana: & $\begin{array}{l}\text { Você participava de eventos ligados ao bem estar da sua comunidade e de participação política antes } \\
\text { do curso? }\end{array}$ \\
\hline Janete: & Não, não, não. \\
\hline
\end{tabular}




\begin{tabular}{|c|c|}
\hline Suzana: & E depois? \\
\hline Janete: & Agora sim. \\
\hline Suzana: & Pode exemplificar? \\
\hline Janete: & Não, assim, política não. Só... Que lá não é política, lá é tipo assim... \\
\hline Suzana: & um centro comunitário...? \\
\hline Janete: & $\begin{array}{l}\text { É uma igreja, sabe? Então eles ajudam muito as pessoa que tem problema, que tá em depressão, } \\
\text { esse tipo... Então, a gente somos voluntária lá, sabe? }\end{array}$ \\
\hline Suzana: & Fale um pouco sobre as suas relações familiares antes e depois do curso. \\
\hline Janete: & Não, pra mim continua igual. Eram ótimas. \\
\hline Suzana: & Como a sua decisão de participar do programa foi recebida pela sua família? \\
\hline Janete: & Ah, foi muito bom por que o meu marido, nesse aspecto aí, ele incentiva bastante. \\
\hline Suzana: & E como você acha que seria hoje? \\
\hline Janete: & Seria melhor ainda ((risos)) \\
\hline Suzana: & $\begin{array}{l}\text { Você se sentia valorizada pela sua família, pelas suas atividades profissionais, pela sua dedicação à } \\
\text { família e filhos, pelo seu envolvimento com as tarefas da casa ou outros? E hoje? }\end{array}$ \\
\hline Janete: & Sim ((com certa relutância)). Hoje também... \\
\hline Suzana: & $\begin{array}{l}\text { Fale um pouco como era a sua participação e envolvimento nas atividades da escola do seu filho, né, } \\
\text { e como está agora? }\end{array}$ \\
\hline Janete: & $\begin{array}{l}\text { Não, toda a vida eu gostei de cobrar deles. Dá direito até a mochila quando chega do colégio eu } \\
\text { revisto tudinho pra ver se tem alguma coisa diferente que não é deles, né? ((risos)). E, agora, } \\
\text { continua do mesmo jeito, melhor ainda. }\end{array}$ \\
\hline Suzana: & $\begin{array}{l}\text { Existia diferença na sua participação na educação dos seus filhos e na participação do pai deles antes } \\
\text { do curso? }\end{array}$ \\
\hline Janete: & Não, não não. Não existia diferença nenhuma, não. \\
\hline Suzana: & Hoje? \\
\hline Janete: & Todos os dois cobra a mesma coisa. O pai cobra mais ainda. \\
\hline Suzana: & $\begin{array}{l}\text { Antes do curso, Janete, o que você achava que determinaria o sucesso dos seus filhos no futuro? E } \\
\text { depois do curso, o que você acha que determina o sucesso dos seus filhos no futuro? }\end{array}$ \\
\hline Janete: & $\begin{array}{l}\text { Ah, tá. Não, pra mim, pra que ele tenha sucesso no futuro é que... tá, depois do curso eu aprendi } \\
\text { bastante coisa, né, teve aquela, eh, como é que fala... Agora não deu pra expressar a aula que nós } \\
\text { tivemos daí; de sessão de preço, né, foi isso? }\end{array}$ \\
\hline Suzana: & Foi. \\
\hline Janete: & $\begin{array}{l}\text { Aquela que passava na (inaudível) também, né? Inclusive, o meu filho fez uma peça no colégio. Aí, } \\
\text { ele: "mãe, o que a gente vai fazer?". "Meu filho, tira os artesanato que a sua mãe tem em casa e cria, } \\
\text { né". Ele fez tudinho. Boto preço, pedindo coisa de preço, ganhou, acho que é 'slongue'. Como é que } \\
\text { fala? Botou "arteganato". Ele disse: "mãe, vou botar uma mistura de arte com artesanato". Aí, ele fez } \\
\text { e ficou muito lindo. Foi ontem! }\end{array}$ \\
\hline Suzana: & Hummm. \\
\hline Janete: & Acho que vai sair no DFTV isso. \\
\hline Suzana: & Olha, que legal! \\
\hline Janete: & $\begin{array}{l}\text { Elas foram lá e entrevistaram o Marcelo ontem no colégio. Aí, ele levou as coisas que eu... "Ó, muita } \\
\text { coisa eu aprendi", né, eu falei pra ele tudo, explicando. Aí ele levou tudinho, os quadros... Inclusive, } \\
\text { depois do curso eu passei a fazer curso de pintura em tela, que eu não tava fazendo ainda. }\end{array}$ \\
\hline Suzana: & Ah, que legal! Parabéns. \\
\hline Janete: & É, aí ele levou as pintura, ah, tirou as foto tudinho e fez, criou um site, sabe, criou um site. \\
\hline Suzana: & Poxa... \\
\hline Janete: & E tá apresentando lá. \\
\hline Suzana: & Então, você acha que é uma coisa que tem a ver com empreender? \\
\hline Janete: & $\begin{array}{l}\text { Oh, tem, muito! Exatamente. Foi o que eu falei pra ele. Eu perguntei... foi o que o professor falou: "se } \\
\text { você tirar aquilo dali, se você... pra poder fazer essa peça que eu fiz aqui, quer dizer, teve que tirar } \\
\text { aqui o que você gastou, você gastou energia, né, pra poder fazer você tem que dar também". Aí, eu } \\
\text { expliquei pra ele tudinho e ele fez: "então, vâmbora botá os preços nos quadros". Botou até o preço } \\
\text { nos quadro! }\end{array}$ \\
\hline
\end{tabular}




\begin{tabular}{|c|c|}
\hline Suzana: & $\begin{array}{l}\text { Bacana. E quais os valores que você achava importante passar pros seus filhos, antes do curso e } \\
\text { depois do curso? }\end{array}$ \\
\hline Janete: & $\begin{array}{l}\text { Não, meus valores que eu sempre falo pra eles é ser honesto, dê valor no que você tem, estude } \\
\text { bastante. Depois do curso continuou a mesma coisa do que eu falo pra eles. }\end{array}$ \\
\hline Suzana: & $\begin{array}{l}\text { Janete, você achava que, por ser mulher, tinha oportunidades e tratamentos diferentes antes do } \\
\text { curso? }\end{array}$ \\
\hline Janete: & $\begin{array}{l}\text { Achava. Por que era o que você via. Todo o lugar que você ia sempre tinha uma discriminação. Mas } \\
\text { depois do curso melhorou bastante o meu modo de ver, tudo. Melhorou muito. }\end{array}$ \\
\hline Suzana: & Você acha que você e sua forma de ver o mundo mudaram depois de participar do Programa? Como? \\
\hline Janete: & $\begin{array}{l}\text { Mudou. Pra mim mudou pra melhor. Que agora eu posso ver que muita coisa que eu pensava que } \\
\text { não conseguiria fazer, agora eu boto aqui na minha cabeça e eu digo "eu consigo, eu sou capaz". } \\
\text { Consigo! }\end{array}$ \\
\hline Suzana: & Você se sente capaz de realizar coisas hoje que não se sentia capaz de realizar antes? \\
\hline Janete: & Sim. \\
\hline Suzana: & Cite exemplos. \\
\hline Janete: & $\begin{array}{l}\text { Sim, com certeza. Acabei de falar agora: agora eu sou capaz! A gente vai fazer uma coisa, bota uma } \\
\text { determinada... pega aquilo dali (que) não sei fazer, mas eu quebro a cabeça até conseguir fazer. E } \\
\text { faço! Quando meu marido vê às vezes fala: "mas você tem muita paciência...". Eu fiz: "eu vou te } \\
\text { mostrar o tapete... chego e mostro". Aí ele: "é muita paciência". ((risos)) }\end{array}$ \\
\hline
\end{tabular}

\section{Cláudia}

Suzana: $\quad$ Então, Cláudia, me fale um pouco sobre a sua participação no Programa Mulheres Mil.

Cláudia: Pra dizer a verdade, eu vim pra cá... como eu fui indicada, né, a senhora acabou de falar pra mim, pelo CRAS... Não só por ter sido indicada por eles, eu... tava passando por um momento muito difícil na minha vida depois da minha gravidez. Então, eu tava muito abatida e tal. Então, eu tava muito revoltada... Então, assim, um... um... chegava, assim, entrava, não tava feliz, aquela coisa... Então, pra mim, tava muito difícil. Mas eu, pelo menos, não tentava faltar, sempre tentava vim... Eu tentava me fortalecer; colocava aquilo na minha cabeça: "eu vou me fortalecer porque, é... por eu tar morando só, eu vou mostrar pra mim, mostrar pras pessoas que eu consigo!". E foi aqui que é... ao passar... ao passar do tempo... eu sempre tive essa dificuldade: quando eu fui fazer um curso, quando eu fui fazer uma coisa ou outra, é... eu tinha dificuldade pra ter um amigo... ou eu tinha um amigo, ou eu não tinha. Ou eu gosto ou não gosto. A pessoa, também, desse jeito comigo. Eu sou uma pessoa muito difícil de lidar. Eu sou, como se dizer, eu sou uma pessoa bipolar. Então, é complicado. Então, quando eu cheguei, foi difícil. Mas também, assim, é... não que eu seja o centro, mas as pessoas, assim, eu cativo muito. Então, foi aquela coisa, eu fiz uma amizade com todo mundo. Acho que não teve um que eu não tenha feito; ainda mais com mulheres. Pra mim, o mais interessante foi com mulheres. Eu nunca gostei de fazer amizade com mulheres. Eu sempre tive uma facilidade com homens porque homens não... né, homem, assim, não só por homem, é... é... claro, dá em cima da pessoa, isso, aquilo outro, mas se você souber relevar, né, a situação, você não abre espaço; pra mulher não, pra mulher é a inveja... a mulher tem tanta coisa hoje pra vo... né... você não... e eu nunca consegui lidar, tanto das jovens como pras mais velhas. E aqui não: teve jovens, mais velhas. Teve, né, vamos considerar, quase idosas.... E ainda mais as ve... as mais velhas ainda, eu amo. Eu já gosto demais, né. essas eu consigo me dar muito melhor. E, assim, eu, aos poucos, fui gostando de cada uma. Acho que umas das coisas que... é... é... foi mais interessante pra mim. E eu já tinha começado a mexer com artesanato. Aí, foi me dando mais ideias, por que eu também sempre fui muito criativa, né... Aí, uma das coisas, também, muito interessante, foi quando eu fiz... eu fiz um coração de espelho... quando eu fiz o espelhozinho, aí eu cheguei pra mim mesma, cheguei a fazer um carrinho. Aí eu fiz um carrinho colocando um negocinho azul e fiz um espelho de carrinho. Só que aí... tanto que os dois quebraram. Não tive mais os dois que eu ia terminar o acabamento e tal... Mas hoje eu tenho em casa coisas; cheguei a guardar espelho, cheguei a guardar umas outras coisas pra fazer, né, por que, na época, eu fazia chaveirinhos e tal... 


\begin{tabular}{|c|c|}
\hline Cláudia: & $\begin{array}{l}\text { Né? Então, eu fazia... Aí, fiz aquele negócio de Natal, né, de colocar assim... e não sei pra quem que } \\
\text { dei; aí, eu dei de presente... Fiz muitas coisas. E dali eu sabia: tinha coisas recicláveis e tal... E } \\
\text { aprendi, tanto aqui, como a gente olha em... em internet e tal, mas em todo lugar. A gente, é... } \\
\text { Assim, Mulheres Mil não foi só pra aprender a mexer com coisa reciclada, foi pra você lidar com as } \\
\text { pessoas, pra você mudar a sua vida. E pra mim foi um ano muito bom. Eu passei seis meses morando } \\
\text { aqui na M Norte e os seis meses que eu morei aqui foram os seis meses que... assim... melhores pra } \\
\text { mim, sabe? Eu vinha pra cá com alegria. Na parte, assim, que era de manhã, né, e eu sempre tive } \\
\text { muita dificuldade de acordar de manhã, e... eu gostava demais. }\end{array}$ \\
\hline Suzana: & É... pra você, quais os pontos fortes e fracos do curso? \\
\hline Cláudia: & $\begin{array}{l}\text {... Ah, algumas coisas eu... ((risos)) algumas coisas eu não concordava, mas eu acho que... é... por } \\
\text { exemplo, eu não concordava com os filmes. Não gostava. Eu sou assim: gosto ou não gosto duma } \\
\text { coisa. Mas tem coisas assim... igual o... o professor Guilherme; já as coisas dele eu já amava: tudo } \\
\text { que ele ensinava eu gostava muito, né? então, assim, mas cada um tem a sua opinião. A menina } \\
\text { pegou e falou assim, né, até concordei com ela agora, né... é... Na parte de alimentação, aquilo ali. A } \\
\text { gente não sabia como a pessoa vinha motivada pra cá. Né? pessoas desistiram por alguns motivos, } \\
\text { outras desistiram por outros, né. uma das pessoas que eu cheguei a encontra-la foi uma mulher que } \\
\text { ela chegou a desistir no início. Não falou qual era o motivo e tal, mas, às vezes, a gente não sabe qual } \\
\text { é o motivo, né? Então, assim... eu não tenho, assim, muita coisa pra criticar tanto. Só acho que, } \\
\text { assim, eu não gostei muito dos filmes; que eu não gostava, assim... tem umas coisas com filmes, } \\
\text { assim... mas no resto, assim, não tenho o que falar mal, não. Que a gente aprendeu muito com as } \\
\text { roupas que você colocava lá nos negóço... é... de fazer... é... as coisas reciclada. Tudo que você fazia } \\
\text { de quando a gente... de quando a gente foi lá pro... esqueci o nome, acho que é UnB. Não sei onde } \\
\text { que a gente foi que a gente fez aqueles negócio de papel... }\end{array}$ \\
\hline Suzana: & Papel artesanal. \\
\hline Cláudia: & $\begin{array}{l}\text { (incompreensível). Que a gente fez... eu tenho aquele... eu tenho aquele... é... eu tenho aquele } \\
\text { caderninho até hoje, o meu é vermelho. Tiro foto e te mando ((risos)) }\end{array}$ \\
\hline Suzana: & ((risos)) \\
\hline Cláudia: & $\begin{array}{l}\text { Lindinho. Eu tenho o meu até hoje. Eu não sei mais o que eu eu tenho, mas eu gosto de guardar as } \\
\text { coisas, assim, que são coisas que lembre. Igual eu falei: o papel. Eu tenho um papel que a gente } \\
\text { anotou, eu anotei o telefone de todas elas. Então, aquilo ali, assim... é muito gostoso de você vim } \\
\text { recordações... de você ver que... (incompreensível) aqui foi um lugar muito bom pra gente, foi muito } \\
\text { bom! Aqui não foi só uma escola de... é... aprendizado só... uma reciclagem ou alguma outra } \\
\text { qualquer coisa. Aqui foi uma coisa de... de... psicológico. Psicológico. Eu, nesse momento, eu acho } \\
\text { que... não é querendo falar, assim, por que ninguém pode falar do outro, mas eu era, assim, uma das } \\
\text { que mais precisava porque eu tava passando, também por um psicológico. Eu sei que todas as outras } \\
\text { precisou e eu acho que ajudou, também, todo mundo. }\end{array}$ \\
\hline Suzana: & De qual matéria ou professor você mais gostou? \\
\hline Cláudia: & ((risos)) A senhora e o Guilherme. \\
\hline Suzana: & $\begin{array}{l}\text { O que você mudaria no Programa Mulheres Mil pra que ele ficasse melhor? Você já falou algumas } \\
\text { coisas, se quiser falar mais... }\end{array}$ \\
\hline Cláudia: & $\begin{array}{l}\text { É... Acho que todo mundo tinha que dar algumas sugestões, mas mudar, assim, isso não. As } \\
\text { sugestões seriam na hora, né? No momento... Não tem o que eu: "ah, vou falar agora uma coisa". } \\
\text { Não, acho que na hora, ali, você fala. É, "meninas, vamos dar umas sugestões. O que que cês acham } \\
\text { que é pra fazer hoje? Semana que vem?”, isso, aquilo. Mas... acho que a coordenação tudo que foi } \\
\text { feito, foi tudo programado de forma certa. }\end{array}$ \\
\hline Suzana: & $\begin{array}{l}\text { Você avalia... Você acha que a sua confiança nas pessoas da sua família mudou antes e depois do } \\
\text { curso? }\end{array}$ \\
\hline Cláudia: & Não. \\
\hline Suzana: & Não... \\
\hline Cláudia: & ((risos)) \\
\hline Suzana: & E em pessoas e grupos fora da sua família? A sua confiança mudou? \\
\hline Cláudia: & Sim. Completamente. \\
\hline Suzana: & Quer falar sobre isso...? \\
\hline Cláudia: & A família ou as pessoas de fora? \\
\hline
\end{tabular}




\begin{tabular}{|c|c|}
\hline Suzana: & Essas outras pessoas, essa mudança, ou... \\
\hline Cláudia: & $\begin{array}{l}\text { É... assim... por eu tá doente, por eu não tá bem psicologicamente, as coisas mudaram bastante, } \\
\text { porque eu já tava me tratando e vim pra cá e isso me ajudou muito. Eu me... é... me afastei. Por mais } \\
\text { que eu estivesse afastada, até mesmo, da minha filha, eu me afastei porque eu já não estava } \\
\text { aguentando o convívio com a minha família. Pra eles [família] não foram mudança. Pra eles é como } \\
\text { se fosse um... pra mim é como se fosse um nada... tivesse fazendo um... qualquer coisinha, qualquer } \\
\text { cursinho. Tanto antes como os depois. Pra eles foram isso. Pra mim não foi. Agora, pra outras } \\
\text { pessoas, não... as outras pessoas viram... até fisicamente, né... viram que eu fiquei diferente. Viram } \\
\text { que eu ficava alegre... entendeu... As pessoas: “Ah, você tá fazendo isso? Tá aprendendo isso, aquilo } \\
\text { outro, e tal!". Então, pras pessoas eu mudei! Então, é tipo assim, eu não quero que uma pessoa } \\
\text { chegue em mim e fale: "ah, você tá mais bonita, isso e aquilo”. Mas, a minha família nunca... nunca } \\
\text { era de me apoiar. As pessoas de fora me apoiavam e falavam pra mim disso. Entendeu? Falavam } \\
\text { quando eu tava no CAPS, quando eu passei um ano todo aqui, entendeu... todos os lugares que eu, } \\
\text { assim, passei e aprendi as coisas na minha vida, as pessoas de fora, sim. A minha família, não. }\end{array}$ \\
\hline Suzana: & Certo... E, você frequentava algum grupo antes do curso? Tipo: atividades culturais, esportivas; é... \\
\hline Cláudia: & Não, só cheguei... \\
\hline Suzana: & Grupos religiosos... \\
\hline Cláudia: & $\begin{array}{l}\text { Não, cheguei a... a... ao CAPS, né? No CAPS fiquei até quase... fiquei até esse ano, que foi muito triste } \\
\text { pra mim; eu tive que sair. Mas, recebi alta. Cheguei a praticar esporte, né? foi pouco antes de ter } \\
\text { minha filha. Foi em } 2012 . \text { Então... Eu frequentava... Eu frequentava Igreja com a minha mãe; parei... } \\
\text { Mas, outras coisas assim, não. }\end{array}$ \\
\hline Suzana: & Mas depois do curso você buscou grupos novos ou permaneceu da mesma forma? \\
\hline Cláudia: & Não. Não, não procurei nenhum, não... Depois, não. \\
\hline Suzana: & $\begin{array}{l}\text { E... e, também, eventos ligados ao bem estar da sua comunidade...? Você participava antes, passou a } \\
\text { participar depois? }\end{array}$ \\
\hline Cláudia: & Não... acho que não, não. \\
\hline Suzana: & $\begin{array}{l}\text { É... você já falou um pouquinho, mas vou pedir pra você falar um pouco mais sobre suas relações } \\
\text { familiares antes e depois do curso. }\end{array}$ \\
\hline Cláudia: & $\begin{array}{l}\text { ((risos)) Então, minha... é... é complicado, porque, no caso, a minha filha... é na guarda da minha } \\
\text { mãe. Hoje, a minha filha tá com a minha mãe; e tá na guarda dela e... é... quando a minha filha } \\
\text { completou um aninho, eu vim pra cá. E eu... eu quis me dar uma chance de... de pensar em mim, } \\
\text { porque eu sei que eu amo a minha filha, mas eu já não aguentava mais aquele sufoco dos três } \\
\text { sofrendo: eu, minha mãe e meu padrasto. Eles dois por tarem cuidando dela, e eu por tar doente. } \\
\text { Entendeu? E tá aquela coisa toda, e... eu não podia cuidar da criança e isso aquilo outro. Então, } \\
\text { quando eu vim pra cá, eles acharam que eu não ia ficar aqui e tal, e... é... eu fiquei um tempo } \\
\text { afastada e tal... só que a minha mãe pegou e me colocou na Justiça. E colocou como se eu tivesse } \\
\text { abandonado a minha filha. Então, muita coisa, assim... eu sofri demais por causa disso. Hoje em dia, } \\
\text { eu ainda tenho que ser assim: "mãe, você acha que ela tá boa pra mim ir ver ela? Pra mim vê-la? Por } \\
\text { que, pra ela não chorar e isso aquilo outro?”. Por que eu não quero... hoje, eu só penso nela; só } \\
\text { penso no bem estar dela. Não quero tirar ela de lá nem nada, porque as condições, como se fala, } \\
\text { física, psicológica, financeira, tenho certeza que, é... pra mim, é pouco pra mim dá pra minha filha. Eu } \\
\text { acho que ela ali com a minha mãe tá melhor... entendeu? }\end{array}$ \\
\hline Suzana: & Hum. \\
\hline Cláudia: & $\begin{array}{l}\text { Que eu quero tá com a minha filha. Mas eu acho que a minha mãe teria, também, que me apoiar. A } \\
\text { minha mãe não, pelo contrário. A minha mãe é daquelas que quer proteger, mas ela quer comandar. } \\
\text { Minha mãe comanda a família, protege a família, mas ela... ela não... não valoriza... não valoriza as } \\
\text { coisas. Por exemplo, ela não valoriza, assim, não se preocupa como eu estou doente agora, a minha } \\
\text { mãe não se preocupou... }\end{array}$ \\
\hline Cláudia: & $\begin{array}{l}\text { Ela não se preocupou se poderia ser uma doença séria, mas se preocupou se eu poderia me } \\
\text { engravidar novamente. Então, ela se preocupa com uma coisa que vai vim a ela, não a mim. Ela não } \\
\text { se preocupa com o meu sentimento; é uma coisa que vai vim ser pra ela, coisa que vai afetar a ela. } \\
\text { Ela não se preocupa que... às vezes, ela fala, assim pra mim, do nada, grita, me xinga, me chama } \\
\text { disso, daquilo outro. Me chama de louca e tal e isso. Ela se preocupa com ela ali naquele momento; } \\
\text { no outro dia, pra ela tá tudo tranquilo. Então, eu tenho uma... um convívio com a minha família }\end{array}$ \\
\hline
\end{tabular}




\begin{tabular}{|c|c|}
\hline & $\begin{array}{l}\text { muito difícil... muito. Morar com eles... aí tem pessoas que falam: “Cláudia, mas por que você não } \\
\text { mora, e isso, aquilo outro?". Porque morar com eles não dá certo. Eu não sou uma pessoa tão fácil } \\
\text { assim, mas também eles não são. Então, pra ver a minha filha, eu vou... a minha filha agora, é... } \\
\text { agora ela me chama de Cláudia, mas, também, me chama de mãe. Eu fui aos poucos ensinando e tal. } \\
\text { Eu não vou tirar ela dali, mas a minha mãe, é... é pra ameaças. Então, a minha mãe juntando } \\
\text { ameaças, fazendo isso e aquilo outro. Então, o convívio com eles, assim, é... é como se hoje, } \\
\text { professora, se eu podesse pegar um avião e passear, e ir pra uma praia e tal. Falar assim: “Não, eu } \\
\text { vou descansar!". Se eu podesse ir, se eu não tivesse uma filha pra ir, acho que eu não voltava nunca } \\
\text { mais. Eu queria me aliviar. A única coisa que me segura é a minha filha. Mas, mesmo assim, ela me } \\
\text { segurando, eles vão me rodeando, me maltratando com palavras, com psicológico... e tal... } \\
\text { entendeu? E mesmo assim... mas eu tomo remédios ainda; tomo os meu remédios neurológicos, } \\
\text { psiquiátricos. Eles... a minha mãe não pensa. Eu peço pra ela, pra que ela não me chame de certas } \\
\text { coisas, ela fala que eu sou esquizofrênica, que eu sou louca. Ela me chama de tudo isso. E ela acha } \\
\text { que isso não abala. Ela fala: "Você não vai ver sua filha hoje, e que não sei o que...". Aí, fala: "ah, } \\
\text { quando você for andar com ela, vê se você segura na mão dessa menina... e isso e aquilo outro". Fala } \\
\text { certas coisas como se eu não fosse filha... mãe... como se ela não saísse de dentro de mim. }\end{array}$ \\
\hline Suzana: & E você... como a sua decisão de participar do Programa na época foi recebida pela sua família? \\
\hline Cláudia: & Tanto faz pra eles. \\
\hline Suzana: & E hoje? \\
\hline Cláudia: & Também... \\
\hline Suzana: & Você se sentia \\
\hline Cláudia: & Não. \\
\hline Suzana: & E hoje? \\
\hline Cláudia: & Também não. \\
\hline Suzana: & E como tá a sua participação com a educação da sua filha? \\
\hline Cláudia: & $\begin{array}{l}\text { Acho que hoje tá bem melhor. Hoje tá bem melhor porque eu tentei ser pra minha filha, não aquela } \\
\text { malvada que a mãe que chega só brigando. Eu não. Eu sou a pessoa, por eu também sou apaixonada } \\
\text { por criança, por eu ser a mãe dela, pelo contrário. Eu sou a pessoa mais carinhosa do mundo. Eu que } \\
\text { sou o grude nela, invés dela ser o grude em mim. Eu abraço, beijo e brinco e não sei o que... ela é } \\
\text { muito agitada, muito, né... aquela coisa. Por que hoje em dia a criança é muito arteira, né? Mas, sou } \\
\text { eu que brinco mais, sou eu que converso... ela, mãe... quando tá arrotando, faz algum gesto... } \\
\text { quando tá fazendo alguma outra coisa errada, eu mostro... Então, eu tento educar na medida do } \\
\text { possível. Então, eu acho que, hoje, ela com três anos e meio, hoje tá bem melhor o nosso convívio; } \\
\text { eu e ela. É, assim, é um amor muito grande. Uma paixão... assim... todo dia é uma paixão uma maior } \\
\text { do que a outra... entendeu? E eu vejo que ela sente uma falta muito grande de mim, mas ela } \\
\text { entende. Ela fica na minha mãe, ela entende isso. Mas a educação, eu acho que tem mudado, sim, } \\
\text { muito. Eu acho que ainda vai mudar. }\end{array}$ \\
\hline Suzana: & $\begin{array}{l}\text { Antes do curso, que que você achava que determinaria o sucesso dela no futuro? Antes do Mulheres } \\
\text { Mil, de você participar do Mulheres... E depois do curso? O que você acha que determina o sucesso } \\
\text { do futuro da sua filha? }\end{array}$ \\
\hline Cláudia: & Antes eu tava muito confusa. Não sei o que... não sei o que dizer, né? Então, eu tava... \\
\hline Suzana: & Ela também era muito novinha, né? \\
\hline Cláudia: & $\begin{array}{l}\text { Muito nova. Então, era muito complicado... Mas, assim... depois, assim, por eu tar mais fortalecida, } \\
\text { eu sei que vai chegar uma hora que ela vai decidir o que ela quer da vida dela. Vai chegar uma hora, } \\
\text { que pode ser daqui a quinze anos, ela tem três. E, hoje, eu acho que vai ter o sucesso, sim, grande, } \\
\text { porque é... eu mudei bastante, e... o meu pensamento é positivo. Que, independente de qualquer } \\
\text { coisa, é... das coisas que a gente passa, das dificuldades que todo mundo hoje em dia passa, tudo... } \\
\text { tudo ruim passa, mas as coisas boas vêm a acontecer. }\end{array}$ \\
\hline Suzana: & E quais os valores você achava importante passar pra ela, antes do curso e depois? \\
\hline Cláudia: & $\begin{array}{l}\text { Antes, os valores... os valores, é... dela poder tocar em mim. Se isso era valor. Era a coisa que eu mais } \\
\text { queria que ela podesse fazer isso. Tocar em mim, porque ela não mamou em mim... Por que eu não } \\
\text { fiz várias coisas... Então, eu não fui, praticamente, mãe. Isso, é das coisas que eu mais... é... me } \\
\text { chateia. Acho que, é, eu tenho mais trauma. Então... era disso, assim. E qual foi a outra pergunta? }\end{array}$ \\
\hline Suzana: & Dos valores, mesmo, que você achava importante passar pra ela, antes e depois do curso. \\
\hline
\end{tabular}




\begin{tabular}{|c|c|}
\hline Cláudia: & $\begin{array}{l}\text { Aí, depois eu, com a sala (?)... quero passar pra minha filha ela continuar na escola, ela continuar na } \\
\text { igreja com minha mãe, e tal. Por mais que eu não esteja frequentando mais a igreja, ela esteja na } \\
\text { Igreja... entendeu? Ela ter boas amizades e... é... formas de educação com a famí... como falar com a } \\
\text { família, que eu falo pra ela: “chama de tia, tio. Fala boa tarde, bom dia, obrigada, agradece, isso...”. } \\
\text { Então, eu quero educar. Então, eu quero pra ela que ela seja uma menina educada, além de linda, } \\
\text { maravilhosa a minha menina, eu quero que ela seja muito educada. Que... é... as coisas que eu não } \\
\text { pude fazer, assim: estudar antes. Hoje, eu sou bem mais velha pra fazer um curso superior, que ela } \\
\text { possa fazer bem mais rápido. Que eu possa dar mais oportunidades pra ela de cursos, né, de outras } \\
\text { coisas. Então, eu quero que ela... né... algum... algum... é... algum concurso, alguma outra coisa } \\
\text { assim. Então, eu tenho certeza que ela vai ser uma grande mulher quando... }\end{array}$ \\
\hline Suzana: & Se Deus quiser! \\
\hline Cláudia: & Quando crescer. Ficar mais velha. Ela fala: "quando eu ficar grandona, mamãe, igual você". \\
\hline Suzana: & $\begin{array}{l}\text { ((risos)). Cláudia, você acha que, por ser mulher, tinha oportunidades e tratamento diferentes? E } \\
\text { hoje? }\end{array}$ \\
\hline Cláudia: & $\begin{array}{l}\text { Acho que sim. É... hoje, depende muito de, assim, do lado da minha família... é... é um preconceito } \\
\text { muito grande, por que... tipo assim, no caso d'eu me relacionar, e isso, aquilo outro... D’eu ser } \\
\text { mulher e às vezes: “ah, você não pode..." é...tipo assim, se eu fosse dirigir um carro. "Ah...!”. As } \\
\text { pessoas já criticam, né, por causa da pessoa ser uma mulher e tal. Hoje, eu vejo que... é diferente... } \\
\text { é... não, moro só, sou mulher. Não é que sou independente não, mas também não quero ser } \\
\text { independente: quero me casar, quero me encontr... quero encontrar uma pessoa, quero ter um } \\
\text { parceiro. Quero me casar, sim. Se for pra ter filho ou não, não sei. Entendeu? Mas, as pessoas tinham } \\
\text { sim... é... Hoje em dia preconceito tá relacionado a tudo, né? Então, mulher, então... eu mesma já } \\
\text { não... eu mesma não... não gostava muito. Não conseguia lidar com as mulheres: entender, } \\
\text { conversar, ter amizade. Então, é muito difícil. Se eu tenho uma amiga, outras, assim, são colegas, } \\
\text { primos, aquelas coisas assim. Agora, amigos homens, colegas é... diferente. }\end{array}$ \\
\hline Suzana: & $\begin{array}{l}\text { E você acha que você mesma e sua forma de ver o mundo mudaram depois de participar do } \\
\text { Programa? E como? }\end{array}$ \\
\hline Cláudia: & $\ldots(($ risos $)) \ldots(($ pausa longa $))$ \\
\hline Suzana: & Fica à vontade. Se não quiser responder, fica à vontade. \\
\hline Cláudia: & $\begin{array}{l}\text { Mas... ((pausa longa)). Acho que foi a oportunidade de a gente, né... que a gente recebeu aqui, foi } \\
\text { uma oportunidade. Como eu disse pra mim... Perguntou se podia mudar o mundo, como é que é? }\end{array}$ \\
\hline Suzana: & Se você e a sua forma de ver o mundo mudaram depois de participar do programa? \\
\hline Cláudia: & Como dizer ((sussurro))... \\
\hline Suzana: & Se você mudou... Você mudou depois de particip \\
\hline Cláudia: & Não, sim! Sim, muito! Sim, eu ach \\
\hline Suzana: & Quer falar um pouco sobre isso? \\
\hline Cláudia: & $\begin{array}{l}\text { Não, eu acho que eu... da minha parte psicológica... acho é mais ainda. Acho que autoestima } \\
\text { também. Por mais que eu esteja assim, né, a autoestima mudou. Meu psicológico... e... foi indo, né... } \\
\text { foi conseguindo desenvolver as coisas, né... }\end{array}$ \\
\hline Suzana: & Você se sente capaz de realizar coisas, hoje, que não se sentia capaz de realizar antes? \\
\hline Cláudia: & Muito mais. $\mathrm{C}$ \\
\hline Suzana: & Por exemplo? \\
\hline Cláudia: & $\begin{array}{l}\text { Ah, há um tempo atrás, agora, eu tentei fazer um negócio da faculdade que eu nunca achei que eu } \\
\text { fosse capaz de fazer na minha vida. E fui, tentei... mas deu alguns problemas... né... e... é... eu tive } \\
\text { que cancelar, aí não deu pra mim dar continuidade. Mas, tipo assim, minha mãe não me apoiou em, } \\
\text { de forma nenhuma. Entendeu? }\end{array}$ \\
\hline Suzana: & E você fez? De qualquer forma... \\
\hline Cláudia: & $\begin{array}{l}\text { Eu fiz, não. Eu comecei a fazer e fiz só dois meses. Só dois meses... e... tô tentando... fiz o } \\
\text { cancelamento, tô tentando fechar novamente e tal... aquela coisa, tá aberto e tal, aquela coisa... mas } \\
\text { eu ainda quero. Quero tentar alguma coisa, mas também é por causa do... tive também alguns } \\
\text { problemas financeiros, aí não deu certo e tal. Então, falei assim: “Não. Algum outro curso, alguma } \\
\text { outra coisa eu vou fazer, né. Não posso, é, parar a minha vida”. Por mais que eu teja já essa idade, eu } \\
\text { quero tentar, sim. Então eu achava, era uma das coisas que eu achava que jamais faria. Era um curso } \\
\text { superior. }\end{array}$ \\
\hline
\end{tabular}




\section{Raquel}

\begin{tabular}{|c|c|}
\hline Suzana: & Raquel, fala um pouco sobre a sua participação no Programa Mulheres Mil. \\
\hline Raquel: & $\begin{array}{l}\text { É... foi muito bom porque antigamente eu não tinha muita ideia de artesanato, dessas coisas assim. } \\
\text { Abriu mais, é... a minha visão sobre os cursos sobre artesanato. Hoje, quando eu vejo, já vejo com a } \\
\text { visão diferente. Aqueles tapete... é que eu fazia crochê, mas eu não fazia nem ideia que isso era } \\
\text { também artesanato. E eu aprendi, é... a valorizar mais, é... com o curso. Porque a minha família } \\
\text { quase toda já mexe com coisa de artesanato também. Meu pai ele trabalha com pote de barro, vaso, } \\
\text { essas coisas. Pra mim, era só um passatempo mesmo. Mas, aí, eu vi que era artesanato. E eu não } \\
\text { continuei mais mexendo com isso por causa que eu não tive oportunidade e por causa das minhas } \\
\text { filhas também, que eu... quando saí, demorou um pouco, eu tive outro filho. E é isso. Foi bom, } \\
\text { também, porque eu conheci muita gente. Algumas pessoas também ainda... é... ainda mantenho a... } \\
\text { é, como se diz, a amizade, mesmo, de longe. E foi bom. ((risos)). }\end{array}$ \\
\hline Suzana: & Você continuou se encontrando com quem? \\
\hline Raquel: & $\begin{array}{l}\text { É, eu vejo a Cida. A Cida e a Dona... aquela que tem um rapaz que ele faz curso aqui, que ele é } \\
\text { deficiente? }\end{array}$ \\
\hline Suzana: & Quais os pontos fortes e fracos do curso, que você achou? \\
\hline Raquel: & Fortes? ((risos))... eu nem sei dizer... ((risos))... Eu não sei responder não... ((risos)) \\
\hline Suzana: & Que que cê achou, assim, que foi bom no curso e o que cê achou que não foi bom. \\
\hline Raquel: & $\begin{array}{l}\text { O que foi bom, foi aprender, fazer... Só que eu queria ter feito mais. Eu queria fazer mais manual, } \\
\text { aquelas coisas mais manual... E foi bom, também, porque eu conheci as meninas, eu conheci você } \\
\text { também... E conheci outros professores e tivemos outras aula também; foi bom também. }\end{array}$ \\
\hline Suzana: & É... de qual matéria, ou de qual professor, você mais gostou? \\
\hline Raquel: & Eu... xô vê... que tinha o seu irmão, né? E tinha o... o outro professor que passava filme, né? \\
\hline Suzana: & Oliver. \\
\hline Raquel: & É isso! Eu gostei de todos. Pra mim não tem o que falar não, foi muito bom. \\
\hline Suzana: & Mas algum cê gostou mais? \\
\hline Raquel: & Não... \\
\hline Suzana: & Algum, assim, que cê falou: “Nossa, essa matéria, com esse professor, pra mim, foi o que eu”... \\
\hline Raquel: & Ah, teve o professor, também, que ensinou nós sobre finança. Também foi muito bom. \\
\hline Suzana: & Ah, o Francisco. \\
\hline Raquel: & $\begin{array}{l}\text { Isso! Mas eu gostei de todos, não tem como eu destacar não. A sua também, foi muito bom. Tinha } \\
\text { muita paciência, por que a gente fala... conversava demais lá na sala. }\end{array}$ \\
\hline Suzana: & $(($ risos $))$ \\
\hline Raquel: & Todos foram muito bom. \\
\hline Suzana: & O que cê mudaria no Programa Mulheres Mil pra que ele ficasse melhor? \\
\hline Raquel: & $\begin{array}{l}\text { Eu... é, botava mais curso, mais aula manual. Fazer mais coisa; mexer com pano, plástico, papel, } \\
\text { vidro, essas coisas. É isso que eu colocava. }\end{array}$ \\
\hline Suzana: & $\begin{array}{l}\text { É... Agora eu vou mudar um pouco de assunto, tá? Aí, vou perguntar coisas, assim, um pouco mais de } \\
\text { você, tá? }\end{array}$ \\
\hline Raquel: & Uhum. \\
\hline Suzana: & Como você avalia a sua confiança nas pessoas da sua família, antes do curso e depois? \\
\hline Raquel: & Deixa eu ver... Avalia a confiança? \\
\hline Suzana: & É. \\
\hline Raquel: & Acho que... boa... a confiança... ((risos)) \\
\hline Suzana: & Mudou de...? \\
\hline Raquel: & Não, mudou não. \\
\hline Suzana: & $\begin{array}{l}\text { Não... E pessoas fora da sua família? Assim, amigos, pessoas conhecidas, vizinhança... Você passou a } \\
\text { confiar mais, ou menos, ou ficou igual, depois que você participou do curso? }\end{array}$ \\
\hline Raquel: & $\begin{array}{l}\text { Acho que com um tempo, também, a gente vai desconfiando mais das pessoa... sei lá. A gente confia } \\
\text { mais com o pé atrás. ((risos)). }\end{array}$ \\
\hline Suzana: & Você frequentava algum grupo antes do curso? Por exemplo: atividades culturais, esportivas; \\
\hline
\end{tabular}




\begin{tabular}{|c|c|}
\hline & associações, grupos religiosos, partidos, sindicatos? \\
\hline Raquel: & Durante o curso, eu fazia estudo da Bíblia. Só isso... \\
\hline Suzana: & E depois do curso você passou a frequentar... \\
\hline Raquel: & Não. \\
\hline Suzana: & Alguma outra coisa? \\
\hline Raquel: & Não. \\
\hline Suzana: & E de eventos ligados ao bem estar da sua comunidade ou de participação política? Você... \\
\hline Raquel: & Não. \\
\hline Suzana: & Também nem antes nem depois? \\
\hline Raquel: & Não. \\
\hline Suzana: & Me fala um pouco, Raquel, sobre as suas relações familiares, antes e depois do curso? \\
\hline Raquel: & Continua normal, mesmo. Antes e depois, do mesmo jeito. Tranquilo. \\
\hline Suzana: & Como a sua decisão de participar do Programa foi recebia pela sua família? \\
\hline Raquel: & Normal. Foi boa! \\
\hline Suzana: & $\begin{array}{l}\text { Voc... Como você acha que seria hoje? Se você decidisse, hoje, participar do Programa, como você } \\
\text { acha que seria? }\end{array}$ \\
\hline Raquel: & Acho que... Pra mim, mesmo? \\
\hline Suzana: & Que que a sua família diria...? \\
\hline Raquel: & Falava que era bom. \\
\hline Suzana: & É? \\
\hline Raquel: & É. \\
\hline Suzana: & Você, antes do curso, se sentia valorizada pela sua família? \\
\hline Raquel: & Sim. \\
\hline Suzana: & E depois do curso? \\
\hline Raquel: & Também. \\
\hline Suzana: & Valorizada pelas suas atividades, pela sua dedicação à família? \\
\hline Raquel: & Sim. \\
\hline Suzana: & Pelo seu envolvimento com as tarefas da casa? \\
\hline Raquel: & Sim... \\
\hline Suzana: & $\begin{array}{l}\text { É... E como é que era, antes do curso, a sua participação na educação e envolvimento nas atividades } \\
\text { da escola da sua filha? }\end{array}$ \\
\hline Raquel: & É... porque antes ela não tava estudado. Aí, agora que começou a estudar. \\
\hline Suzana: & E como é que é hoje a sua... \\
\hline Raquel: & $\begin{array}{l}\text { Eu participo bastante. Eu participo das reuniões. Em casa, também, eu tenho que ajudar nos dever. } \\
\text { Levo direto pra escola. }\end{array}$ \\
\hline Suzana: & $\begin{array}{l}\text { Você sente que o seu envolvimento com a educação dela, hoje, tem alguma coisa a ver com a sua } \\
\text { participação no Programa? Ou não? }\end{array}$ \\
\hline Raquel: & $\begin{array}{l}\text { Também, tem. Porque teve algumas aulas também que serviu pra abrir os olhos da gente que } \\
\text { estudar, também, é muito bom. Faz a gente crescer pro mundo, pra gente mesmo... }\end{array}$ \\
\hline Suzana: & Antes do curso, o que você achava que determinaria o sucesso das suas filhas no futuro? \\
\hline Raquel: & Antes do curso? \\
\hline Suzana: & É. \\
\hline Raquel: & Hum... não sei responder... ((risos)) \\
\hline Suzana: & O que você acha, hoje, que vai determinar o sucesso das suas filhas no futuro? \\
\hline Raquel: & O estudo. \\
\hline Suzana: & Você já pensava assim antes do curso? \\
\hline Raquel: & Não. \\
\hline Suzana: & Quer falar um pouquinho sobre isso? \\
\hline Raquel: & $\begin{array}{l}\text { É, por que, é... eu acho assim, que, quando eu cheguei aqui... eu vim do Piauí, eu vim pra cá, aí eu } \\
\text { tive oportunidade de estudar, mas eu tinha medo de estudar. Aí, eu não aproveitar pra estudar. } \\
\text { Agora que eu tenho filho, aí fica mais difícil. Aí, hoje, eu não tenho uma profissão boa porque eu não } \\
\text { estudei. Porque se eu tivesse estudado, eu tinha profissão... Aí, hoje, se eu for procurar emprego só } \\
\text { acho uma coisa que não é muito boa, por que eu não estudei... Só que eu ainda tenho esperança que }\end{array}$ \\
\hline
\end{tabular}




\begin{tabular}{|c|c|}
\hline & $\begin{array}{l}\text { eu vou estudar quando as minhas meninas crescesse mais um pouco, que eu puder deixar essa daqui } \\
\text { com o pai. Aí, eu vou voltar a estudar e fazer minhas coisas que eu quero de novo. ((risos)) }\end{array}$ \\
\hline Suzana: & E quais os valores você achava importante passar pros seus filhos antes do curso? \\
\hline Raquel: & Antes do curso? Valor é... é a sabedoria, é saber respeitar os outros, é o estudo... é isso. \\
\hline Suzana: & Depois que você fez o curso mudou os valores que você... \\
\hline Raquel: & Mudou porque pra melhor, pra ver mais ainda as coisas. Tem que estudar mesmo. \\
\hline Suzana: & $\begin{array}{l}\text { É... Raquel, você achava que, por ser mulher, tinha oportunidades e tratamento diferentes antes do } \\
\text { curso? }\end{array}$ \\
\hline Raquel: & Não... \\
\hline Suzana: & $\begin{array}{l}\text { E depois do curso? Você acha que, por ser mulher, tem oportunidades e tratamento ((choro de } \\
\text { criança)) diferentes? }\end{array}$ \\
\hline Raquel: & Acho que não. Tratamento acho que tem que pra todo mundo ser igual ((choro de criança)). \\
\hline Suzana: & $\begin{array}{l}\text { Ela quer mamar. Fica à vontade, viu, tem nada não. Pode dar de mamar. Sou mulher, dei de mamar } \\
\text { também... }\end{array}$ \\
\hline Raquel: & $(($ risos $))$ \\
\hline Suzana: & Pode ficar tranquila. Cê quer parar um pouquinho pra não (incompreensível) ela? \\
\hline Raquel: & Não, não, pode continuar. \\
\hline Suzana: & É... E a sua forma de ver o mundo? Você acha que mudou depois do curso, Raquel? \\
\hline Raquel: & $\begin{array}{l}\text { Mudou mais, porque cada vez quando a gente vai fazer um estudo, um curso, e a gente aprende mais } \\
\text { coisa, parece que abre mais os olhos da gente. Aí, quando vê alguma coisa, já vê mais diferente. } \\
\text { Porque antes a gente não sabia, não entendia daquela coisa; via, tanto faz. Não fazia importância } \\
\text { nenhuma. }\end{array}$ \\
\hline Suzana: & E hoje, você se sente capaz de realizar coisas que não se sentia capaz de realizar antes? \\
\hline Raquel: & Sim. \\
\hline Suzana: & Por exemplo? \\
\hline Raquel: & $\begin{array}{l}\text { Ah... correr atrás, assim, de um estudo, de um curso. Porque eu não tinha coragem antigamente. E eu } \\
\text { tinha, é, como fazer porque eu era sozinha, não tinha filho. Não tinha coragem. Agora, hoje, e por } \\
\text { causa dos filhos, a gente precisa, tem que ter coragem de ir atrás. Vontade, mesmo. }\end{array}$ \\
\hline Suzana: & Legal. Quer colocar mais alguma coisa, Raquel? Falar mais alguma coisa? \\
\hline Raquel: & Não sei... ((risos)). Acho que não... ((risos)) \\
\hline Suzana: & $\begin{array}{l}\text { É... deixa eu ver se tem mais alguma pergunta. Você se sente mais forte depois de ter participado do } \\
\text { curso? }\end{array}$ \\
\hline Raquel: & Sinto. E era tão bom aquele curso... e acabou de vez, né? \\
\hline Suzana: & $\begin{array}{l}\text { Então, é... é porque... no ano passado não teve porque... a coordenadora... ela teve que sair de } \\
\text { licença médica. Eu já não tava na coordenação. Eu avisei pra você, né, que ia sair? }\end{array}$ \\
\hline Raquel: & Avisou. \\
\hline Suzana: & Mas, aí, esse ano já não teve porque o programa não aconteceu em lugar nenhum. \\
\hline Raquel: & Aí, acabou mesmo? \\
\hline Suzana: & Não. Não sei se acabou. Eu acho que, talvez, no ano que vem, volte. \\
\hline Raquel: & Mas era tão bom! E ele devia continuar a ter mais fases, sei lá. Era bom... ((risos)) \\
\hline Suzana: & É... \\
\hline Raquel: & $\begin{array}{l}\text { A gente aprender mais coisas... era muito bom. Inclusive, a minha filha fala o tempo todo. Tem uma } \\
\text { roupa lá que ela veja, ela fala: "Mãe, cê vai pra onde? Vai pro curso com essa roupa?". Ela fala o } \\
\text { tempo todo do curso e ela veio só umas duas vezes aqui. }\end{array}$ \\
\hline
\end{tabular}

\section{Marisa}

Suzana: $\quad$ É... Marisa, me fala um pouco sobre a sua participação no Programa Mulheres Mil.

Marisa: Olha, eu acho que minha participação foi bastante ativa porque, é... eu fiz o curso completo, né, participei de todas as atividades, aprendi muita coisa, é.. embora eu não esteja trabalhando na área, eu economizo muito com pequenas lembranças que eu faço pra dar de presente, e dou sugestões, né, pras pessoas... é... aproveitarem uma coisa ou outra pra fazer um arranjozinho, né, um porta retrato, é... um vaso, né, com jornal... É... E eu achei muito importante. É...Me enriqueceu muito 


\begin{tabular}{|c|c|}
\hline & $\begin{array}{l}\text { esse, é... esse curso. Trabalhar com o aproveitamento de coisas que, normalmente, a gente joga fora, } \\
\text { né. Você nem pensa que aquilo... É, em nenhum momento a gente pensa que aquilo, assim, a gente } \\
\text { poderia aproveitar. Então, foi muito importante. }\end{array}$ \\
\hline Suzana: & Certo... \\
\hline Marisa: & Pra mim, foi importante. \\
\hline Suzana: & Uhum. De qual matéria ou professor você mais gostou? \\
\hline Marisa: & $\begin{array}{l}\text { É, eu sou até um pouco suspeita, mas eu gostei muito da professora Suzana porque foi com ela que } \\
\text { eu aprendi mais coisas, é... Ela trabalhou muito a parte de estimulação, né, porque... É... Não só eu, } \\
\text { mas muitas colegas, assim, cada uma chegava, assim. Com astralzinho baixo. E ela conversando, } \\
\text { estimulando, é... Dando sugestões... É... E eu me identifiquei muito com a professora Suzana. Aprendi } \\
\text { muito com ela. }\end{array}$ \\
\hline Suzana: & Marisa, o que você mudaria no Programa Mulheres Mil pra que ele ficasse melhor? \\
\hline Marisa: & $\begin{array}{l}\text { É ((pausa longa))... Olha... Eu não achei muito defeito nesse Programa não, como aluna. Porque nós } \\
\text { recebemos toda a assistência, né. Aqui, o IFB; por parte da nossa professora... né.. nós conhecemos } \\
\text { outros é... outras escolas IFB mesmo, né? Fomos do Plano Piloto, fomos de Planaltina... É... Houve, } \\
\text { assim, muita troca de experiências... é, seria o governo investir no lanche, por incrível que pareça. } \\
\text { Por que muitas vezes algumas pessoas chegavam aqui, muitas vezes, sem tomar o cafezinho e tudo, e } \\
\text { era nossa professora que trazia o pãozinho, né, o cafezinho pra gente lanchar. E depois que nós } \\
\text { fomos fazendo uma vaquinha, mas muitas pessoas não tinham como trazer na vaquinha nem o } \\
\text { dinheirinho pra comprar. Então, eu acho que o governo tinha que investir nesse lanche, que é muito } \\
\text { importante. Que muitas pessoas não tem ele em casa, né. Sai de casa sem lanchar... e ele dá nova } \\
\text { vida. A pessoa alimentada tem nova disposição, não é? Então, eu investiria no lanche, por que o } \\
\text { restante foi... tudo bem, eu sei das dificuld... por que a professora passou muitas dificuldades, né? } \\
\text { Mas como aluna, foi ótimo. Muito bom. }\end{array}$ \\
\hline Suzana: & $\begin{array}{l}\text { Agora entrando um pouco mais, assim, em aspectos mais da sua vida. Marisa, como você avalia a sua } \\
\text { confiança nas pessoas da sua família, antes do curso e depois do curso? Se mudou alguma coisa... }\end{array}$ \\
\hline Marisa: & $\begin{array}{l}\text { Me achava muito chique estudando no IFB... Né? Recebi muitos elogios porque é uma escola de } \\
\text { referência. No começo, quando eu fazia aquelas peçazinhas, assim, mal trabalhadas e tudo, eu olhava } \\
\text { e ficava tentando consertar. Mas aí foi melhorando. É... melhorando e eu começando a fazer em casa } \\
\text { e passei a dar de presente, né. Aí as pessoas passaram a elogiar as peçazinhas, né? E aquilo me } \\
\text { envaidecia muito. É... E, e hoje eu tenho o material em casa, aí eles chegam: "como é, não vai fazer } \\
\text { mais não? Parou? Não! Eu tô querendo isso, querendo aquilo". Aí, eu já tô passando a ensinar a eles } \\
\text { a fazer, entendeu, a peça. Porque é muito importante você fazer, é, uma coisa e colocar dentro da } \\
\text { sua casa. Um jarro, você pegar um porta retrato que você compra ele, aí, com três reais, aí você, é... } \\
\text { Enfeita ele com pedrinhas, é... conchinhas, é... muitas coisas você pode usar. }\end{array}$ \\
\hline Suzana: & $\begin{array}{l}\text { E você avalia que a sua confiança nas pessoas e grupos fora da sua família mudou? De antes do curso } \\
\text { pra depois? Assim, sua confiança nas pessoas, em geral. }\end{array}$ \\
\hline Marisa: & $\begin{array}{l}\text { Mudou, assim, porque quando eu entrei aqui, eu tava, assim, com o astralzinho caído. E... Entrei aqui } \\
\text { por um acaso, procurando alguma coisa que eu não sabia nem o que eu queria fazer. Aí, o rapaz me } \\
\text { disse: “olha, só tem esse aqui, curso de Mulheres Mil. Não sei não...”. E eu pensei: “o que será isso, } \\
\text { meu Deus?". Aí, eu fiz essa inscrição. No começo, saía de casa desanimadinha... Aí, fui melhorando, } \\
\text { melhorando, melhorando. E, e tudo foi evoluindo. Aí, hoje, comparando hoje, é... a minha vida com } \\
\text { aquele período de quando eu entrei, tá outra coisa. Né... Eu estou mais confiante... Já arrumei, assim, } \\
\text { até um trabalho pra eu fazer. E tô bem tranquila, graças a Deus. }\end{array}$ \\
\hline Suzana: & $\begin{array}{l}\text { E você percebe que a sua confiança nas pessoas mudou? Nas pessoas... Cê confia mais, menos nas } \\
\text { pessoas? Cê percebe se teve alguma mudança na confiança das pessoas antes e depois do curso? Ou } \\
\text { continua igual? }\end{array}$ \\
\hline Marisa: & $\begin{array}{l}\text { Acho que continua igual. Agora o que eu passei foi a... assim, a... a ensinar as pessoas a colocarem a } \\
\text { mão na massa. Né? Por que cê não pode entregar tudo pronto. As vezes a pessoa chega, assim, } \\
\text { reclamando: "ah, tô passando dificuldade e tal". Fala: "então, faz isso, isso e isso. Vende! Faz aquilo e } \\
\text { tal. Faz uma coisa, faz outra ". Né? Agora, a confiança, em si, eu acho que tá mais ou menos... }\end{array}$ \\
\hline Suzana: & $\begin{array}{l}\text { Marisa, você frequentava algum grupo antes do curso? Por exemplo: atividades culturais, esportivas; } \\
\text { associações; grupos religiosos; sindicatos... Passou a frequentar depois? }\end{array}$ \\
\hline Marisa: & Não... não. \\
\hline
\end{tabular}




\begin{tabular}{|c|c|}
\hline Suzana: & $\begin{array}{l}\text { E eventos ligados ao bem estar da sua comunidade e de participação política? Reuniões em } \\
\text { prefeituras, é... comitês, alguma coisa, você participava antes? Passou a participar depois? }\end{array}$ \\
\hline Marisa: & Não... \\
\hline Suzana: & $\begin{array}{l}\text { Marisa, é... Me fala um pouco sobre as suas relações familiares, antes e depois do curso? Se teve } \\
\text { alguma... Você percebe se houve alguma mudança. }\end{array}$ \\
\hline Marisa: & $\begin{array}{l}\text { É... Por a gente melhorar o astral, eu acho que tudo melhora. Né? Quando cê tá com baixo astral, } \\
\text { você não vê, assim, coisas positivas, assim... até nas pessoas! Você fica negativa demais, assim... Aí, } \\
\text { por a gente melhorar, você ter novas perspectivas, eu acho que é até automático que a gente } \\
\text { melhore, assim, no relacionamento com quem está ali convivendo conosco. Eu acho que eu } \\
\text { melhorei. }\end{array}$ \\
\hline Suzana: & É... como a sua decisão de participar do Programa foi recebida pela sua família na época? \\
\hline Marisa: & $\begin{array}{l}\text { Não acreditaram muito. “Que curso é esse? Que que é isso? Mulheres Mil? Cê vai fazer o que lá?”. Aí } \\
\text { eu explicava... é, aí foi indo. Aí, eu comecei a aparecer com as peças em casa... né. Aí, depois que eu } \\
\text { comecei a aparecer com as peças, eu tenho um, assim, bastante netos, e fui envolvendo os netos } \\
\text { também... né... no, assim, pra fazer... mexer com artesanato. E aí, eles começaram a acreditar... e foi } \\
\text { a partir daí, né. E foi bom... }\end{array}$ \\
\hline Suzana: & $\begin{array}{l}\text { Você acha que, se você hoje decidisse participar de outro curso, de alguma coisa, como é que você } \\
\text { acha que a sua família ia receber? }\end{array}$ \\
\hline Marisa: & Ah, eu acho que eles iam gostar muito... Com certeza. \\
\hline Suzana: & $\begin{array}{l}\text { Você se sentia valorizada pela sua família, pelas suas atividades, pela sua dedicação à casa à família... } \\
\text { é... antes do curso? E depois? }\end{array}$ \\
\hline Marisa: & $\begin{array}{l}\text { Ó, pela minha família, sim. Agora, o meu esposo, ele é, assim, apagadinho... eu acho que ele não... } \\
\text { não dava assim muita... não dava valor, né? Não valorizava... Esse curso. Aí, depois que eu comecei a } \\
\text { fazer as pecinhas que ele começou a... a ver, né? “Ah, você gasta muito dinheiro comprando material } \\
\text { e isso não vai render nada. Você não vai conseguir ganhar nem o que você gastou. Você gasta } \\
\text { dinheiro e fica só dando de presente pros outros"... né... Marido é assim. Mas, o restante da minha } \\
\text { família não. Meus filhos dão muita força. }\end{array}$ \\
\hline Suzana: & $\begin{array}{l}\text { É... e por falar em filhos, então, eu vou fazer algumas perguntas e aí a gente vai tentar adaptar por } \\
\text { que eu fiz elas mais pensando em filhos em idade escolar. Mas a gente tenta adaptar; que seus filhos } \\
\text { já não estão mais em idade escolar, né? ((risos)) }\end{array}$ \\
\hline Marisa: & É... \\
\hline Suzana: & $\begin{array}{l}\text { Fale um pouco, é... como era a sua participação e envolvimento... na educação, né, dos seus filhos e } \\
\text { como está agora? ((risos)) Acho que essa pergunta não cabe muito, né? }\end{array}$ \\
\hline Marisa: & $\begin{array}{l}\text { ((risos)). Mas... olha, eu sofri muito com os meus filhos porque eu tinha uma vida parecida com a sua. } \\
\text { E a diferença é que eu não tinha um marido presente, né, pra me ajudar. Quando o meu filho tinha } \\
\text { três meses, o segundo, aí o meu esposo saiu de casa. Arrumou outra pessoa, né, assim... E foi muito } \\
\text { difícil, muito difícil. Eu trabalhava num local que tinha, de dez em dez dias eu tinha que trabalhar à } \\
\text { noite; virava a noite trabalhando. Chegava em casa cansada, com sono, e não conseg... não podia } \\
\text { dormir, que tinha as crianças pra olhar. É... eu tinha que tomar... e pra trabalhar à noite, eu não tinha } \\
\text { resistência física, aí eu tinha que tomar coca-cola com café pra conseguir passar à noite. E outra } \\
\text { coisa, assim, é... eu, sem... não tinha empregada, assim... a empregada não firmava, né... é... e... às } \\
\text { vezes eu arrumava ela no domingo à noite, na segunda-feira eu tinha que entregar meus filhos pra } \\
\text { ela, né... aquilo me matava... a gente, como mãe, é um sofrimento a gente entregar os filhos da } \\
\text { gente nas mãos de uma pessoa que você não conhece. Então, eu acredito que meus filhos sofreram } \\
\text { muito, eu sofri muito... mas, nós vencemos. Né... foi luta. }\end{array}$ \\
\hline Suzana: & $\begin{array}{l}\text { É... antes do curso, o que você achava que determinaria o sucesso dos seus filhos? Né. e depois do } \\
\text { curso, o que você acha? }\end{array}$ \\
\hline Marisa: & Bem, eu já tinha uma visão, né? \\
\hline Suzana: & Ahan. \\
\hline Marisa: & Assim, da... e... \\
\hline Suzana: & Ou dos seus netos, talvez. ((risos)) \\
\hline Marisa: & $\begin{array}{l}\text { ((risos)) E... e... meus filhos, é... a gente nunca deixa de dar palpite, de estimular os filhos, de... dar } \\
\text { sugestões, assim, pra eles progredirem na vida... e, eu já fazia isso e continuei fazendo. Né... só que } \\
\text { de uma forma, assim, né, até com mais abertura, eu acredito. Né... que hoje eu chamo os meus }\end{array}$ \\
\hline
\end{tabular}




\begin{tabular}{|c|c|}
\hline & $\begin{array}{l}\text { filhos, se precisar, né, dar bronca; eles com quase } 40 \text { anos, eu chamo, né... e, e... eu vejo o meu } \\
\text { marido com os filhos dele, ele não consegue fazer isso que eu faço, né, com os filhos já adultos. Mas } \\
\text { eu chamo na regulagem ((risos))... }\end{array}$ \\
\hline Suzana: & $(($ risos $))$ \\
\hline Marisa: & $\begin{array}{l}\text { Então, eu acho que foi boa... a gente fica mais forte, né. Quando você tá bem, faz uma coisa, assim, } \\
\text { que tá gostando; que você se sente bem! Você fica mais forte, pra enfrentar os desafios, pra ajudar } \\
\text { os filhos, né... “Meu filho, não é assim, meu filho. Cê não pode fazer assim. Esse negócio tá errado! } \\
\text { Isso aqui tem que ser assim, ó. Assim, cê pode ir..." E eles vão e se dão bem. }\end{array}$ \\
\hline Suzana: & $\begin{array}{l}\text { E quais os valores que você achava importante passar pros seus filhos ou netos antes do curso? E } \\
\text { mudou, depois do curso? }\end{array}$ \\
\hline Marisa: & $\begin{array}{l}\text { Não, basicamente... Não, não teve, assim, muita mudança, né? Porque o que eu ensinei a meus } \\
\text { filhos, ao longo da vida, foi eles serem pessoas honestas, né; esforçadas, né; estudarem bastante... e } \\
\text { fazer o que gosta no trabalho... né... até hoje eu converso com eles: “se não estão gostando do que } \\
\text { estão fazendo, estão jovens, mudem! Tem como mudar, né, faz outra coisa!". Porque antigamente } \\
\text { não, antigamente a gente não tinha esse negócio. O que aparecia a gente tinha que fazer. Mas hoje } \\
\text { não, eles têm um leque de coisas na frente deles. Então, se não estão gostando, muda. Nunca é } \\
\text { tarde... né? Sempre há tempo. }\end{array}$ \\
\hline Suzana: & $\begin{array}{l}\text { Marisa, é... você, antes do curso, achava que, pelo fato de ser uma mulher, tinha oportunidades e } \\
\text { tratamentos diferentes? E depois do curso? Cê acha que mudou? Cê entendeu a pergunta? ... }\end{array}$ \\
\hline Marisa: & Uhum. \\
\hline Suzana: & É meio complicada essa... \\
\hline Marisa: & Eu acho que mudou muito não. \\
\hline Suzana: & Você acha que tinha oportunidades e tratamentos diferentes por ser mulher? \\
\hline Marisa: & Não... não... Antes não. Comparando antes com depois, né? \\
\hline Suzana: & Depois você percebeu alguma coisa nesse sentido? \\
\hline Marisa: & Não... \\
\hline Suzana: & $\begin{array}{l}\text { É... você acha que você e sua forma de ver o mundo mudaram depois de participar do programa? } \\
\text { Como? }\end{array}$ \\
\hline Marisa: & $\begin{array}{l}\text { A gente não se acomodar... estar sempre inventando uma coisa. Então, é... eu não fico parada. } \\
\text { Quando eu estou parada, eu estou sempre inventando. Aí, eu vou lá no meu escritoriozinho, no } \\
\text { fundo de casa, e pego umas conchinhas, pego uma coisa, pinto. Se não ficou boa, eu faço de novo... } \\
\text { né... vou nas conchinhas fazer um porta retrato. E aquilo passa um dia... né... }\end{array}$ \\
\hline Suzana: & Você se sente capaz de realizar coisas hoje que não se sentia capaz antes? Por exemplo. \\
\hline Marisa: & $\begin{array}{l}\text { Fazer um jarro pra colocar flores com jornal. Eu acho que aquela peça foi uma peça preciosa que a } \\
\text { professora Suzana me ensinou a fazer. Uma arte, assim, né, fabulosa. E eu tinha vontade de comprar } \\
\text { um jarro daquele. E a gente chega lá, sempre caro, o dinheiro tá pouco. E, de repente, eu aprendi a } \\
\text { fazer. Pra mim, foi fabuloso! }\end{array}$ \\
\hline Suzana: & ((risos)) Tem foto? Depois eu quero ver... \\
\hline Marisa: & Ah, não tem... ((risos)) \\
\hline Suzana: & $\begin{array}{l}\text { Mas, assim, sem ser na área de artesanato. Na sua vida, você se sente, que hoje é capaz de realizar } \\
\text { coisas que não era antes? }\end{array}$ \\
\hline Marisa: & $\begin{array}{l}\text { Ah, com certeza! Muitas coisas. Essa experiê... isso foi um desafio, né? Por que eu tinha a teoria [da } \\
\text { área de Serviço Social], mas eu não tinha a prática. Então pra mim, foi um desafio. Um desafio a cada } \\
\text { dia, por que cada lugar que você chega, é uma história... }\end{array}$ \\
\hline Suzana: & A perícia, você tá falando? \\
\hline Marisa: & É... \\
\hline Suzana: & Você é formada em? \\
\hline Marisa: & Serviço Social. \\
\hline Suzana: & Serviço Social... \\
\hline Marisa: & $\begin{array}{l}\text { É... Quer dizer, eu tinha a teoria, mas a prática, é... é diferente. Ainda mais numa área que você... } \\
\text { cada lugar que você chega, a pessoa tem uma história de vida, tem pobreza... você chega numa casa } \\
\text { que não tem comida... a pessoa fala: "olha, a senhora pode abrir a geladeira. Abra o armário pra } \\
\text { senhora ver". Cheguei numa casa esses dias eles tavam cinco pessoas almoçando arroz, purinho. }\end{array}$ \\
\hline
\end{tabular}




\begin{tabular}{|l|l|}
\hline & $\begin{array}{l}\text { Então, a gente faz uma reflexão, né, e é quando a gente tem consciência de que nós somos ricos, né, } \\
\text { porque não falta o alimento na nossa casa. Que cada perícia é uma história. }\end{array}$ \\
\hline Suzana: & $\begin{array}{l}\text { Você sente que a sua participação no Programa Mulheres Mil, é... trouxe alguma experiência } \\
\text { importante pra sua atividade profissional hoje? }\end{array}$ \\
\hline Marisa: & $\begin{array}{l}\text { Parece que, é... daquilo, do curso do Mulheres Mil, as coisas deslancharam, né... e, o grupo foi muito } \\
\text { bom, daqui do curso. A interatividade que aconteceu, né, com a sua preciosa colaboração, o grupo } \\
\text { ficou muito unido... e eu acho que nós saímos daqui fortalecidas e com isso a gente fica corajosa... } \\
\text { né... eu fiquei corajosa...Eu acho que fiquei muito mais corajosa pra enfrentar os desafios. E dali pra } \\
\text { frente as coisas foram deslanchando. }\end{array}$ \\
\hline Suzana: & $\begin{array}{l}\text { Bacana... quer acrescentar alguma coisa, Marisa? } \\
\text { Marisa: }\end{array}$ Foi um curso fabuloso! Foi muito bom e eu gostaria que ele não parasse, né... \\
\hline Suzana: & $\begin{array}{l}\text { É. } \\
\text { Marisa: }\end{array}$ \\
$\begin{array}{l}\text { é... muitas pessoas que precisam, não tem vont... assim... se sentem mais capacitadas pra voltar pra } \\
\text { uma sala de aula. Eu acho que o Mulheres Mil, aquele original nosso, ele deveria voltar. Ele é um } \\
\text { curso importante! Ele dá um novo sentido de vida pras pessoas; ensina as pessoas a trabalhar, a } \\
\text { vender, a ganhar um dinheirin... é isso que a gente tá precisando... né... O profissionalizante ele é } \\
\text { bom para os jovens. Mas uma pessoa que não conseguiu construir muito ao longo da vida, ela precisa } \\
\text { trabalhar pra ganhar dinheiro pra sobreviver. Então, tem que ser aquele outro. Foi um curso rápido, } \\
\text { bom, e que nós saímos daqui bem preparadas... né... só não tá ganhando dinheiro quem não } \\
\text { continuou botando a mão na massa... por que quem... quem continuou trabalhando, desenvolvendo } \\
\text { o que aprendeu aqui, está sobrevivendo. Não ganha um dinheirão, mas também não passa fome. } \\
\text { Né? Então, eu até lamento não ter inscrição pra esse curso novamente; praquele original, como foi o } \\
\text { nosso. }\end{array}$ \\
\hline
\end{tabular}

\section{Ana}

\begin{tabular}{|c|c|}
\hline Suzana: & Ana, por favor, fale um pouco sobre a sua participação no Programa Mulheres Mil. \\
\hline Ana: & Sobre a minha participação? \\
\hline Ana: & $\begin{array}{l}\text { Não, pra mim foi muito bom, né. Porque, eu já não trabalho fora. Aí, pra mim arrumar um curso } \\
\text { desse, assim, achei que... que eu ia evoluir, né? Como tinha tudo pra evoluir. Só não evolui mesmo } \\
\text { porque eu tenho ela, né, e ela tem problema de saúde. Aí, eu entrei num serviço; não fiquei nem um } \\
\text { mês completo, tive que sair... por causa dela. Mas o curso pra mim foi ótimo, mas eu não pude dar } \\
\text { continuidade no curso não, né. Nem continuar fazendo os trabalhos... Porque, como eu tenho ela que } \\
\text { tem problema de saúde, eu não posso... Praticamente eu vivo pra ela. Tô quase sempre em hospital. } \\
\text { Já fui pra São Paulo. Esse ano, mesmo, em julho, fui pra São Paulo com ela, que ela foi pra ver se } \\
\text { precisava fazer transplante. Ela tem problema no fígado. Daí... Eu parei. Fiz o curso, deu tudo certo, } \\
\text { mas tive que parar. Só em casa, mesmo, cuidando dela e da família, mesmo. }\end{array}$ \\
\hline Suzana: & Pra você, quais os pontos fortes e fracos do curso? \\
\hline Ana: & $\begin{array}{l}\text { Quais os ponto forte? Os forte, assim, a gente pode evoluir, pode... dar continuidade ao curso, né? } \\
\text { Em outras coisa, ou mesmo na reciclagem, né? E os ponto fraco... Assim, os ponto fraco pra mim que } \\
\text { achei foi só... no termo dela, né? Que não tinha onde deixar... Quando tem, assim, participação fora, } \\
\text { né? Acho que só isso, mais nada. }\end{array}$ \\
\hline Suzana: & De qual matéria ou professor você mais gostou? \\
\hline Ana: & $\begin{array}{l}\text { Xô vê... a matéria que eu gostei mais... gostei mais da, da... quando a gente faz o... o... quando a gente } \\
\text { vai trabalhar, mesmo, com os produto, né? Da... reciclado. E dos professor, eu gostei mais foi você, } \\
\text { né. Foi o que mais a gente teve a participação, o que mais ficou com a gente na sala de aula... }\end{array}$ \\
\hline Suzana: & O que você mudaria no Programa Mulheres Mil pra que ele ficasse melhor? \\
\hline Ana: & $\begin{array}{l}\text { Deixa ver o que eu mudaria ((sussurro))... Acho que eu mudaria, assim, o tempo é muito curto, né? } \\
\text { Gostaria que fosse um tempo maior, porque, aí, a gente aprendia mais, né? Tinha mais oportunidade } \\
\text { de aprender outras coisas. }\end{array}$ \\
\hline Suzana: & Ana, como você avalia a sua confiança nas pessoas da sua família, antes e depois do curso? \\
\hline Ana: & $\begin{array}{l}\text { Muito bom. Eles sempre me deram muita força, né... Como eu avalio? Assim... Nota oito, mais ou } \\
\text { menos. Porque, algumas coisas, eu acho assim: “Ah, você vai fazer o curso, depois não pode levar a } \\
\text { frente, né? Aí, praticamente não adiantou". Eles falam assim: "não adiantou nada. Ficou esse tempo }\end{array}$ \\
\hline
\end{tabular}




\begin{tabular}{|c|c|}
\hline & $\begin{array}{l}\text { no curso, mas depois teve que parar...". Mas, eles me deram muita força enquanto eu tava fazendo, } \\
\text { né... }\end{array}$ \\
\hline Suzana: & E como você avalia sua confiança nas pessoas e grupos fora da sua família, antes e depois do curso? \\
\hline Ana: & $\begin{array}{l}\text { Passei a confiar mais! Tem pessoas muito boa, né? Ainda... Eu me dei muito bem com os grupo. } \\
\text { Passei a confiar bastante nos grupo fora. }\end{array}$ \\
\hline Suzana: & $\begin{array}{l}\text { Você frequentava algum grupo antes do curso? Por exemplo: atividades culturais ou esportivas, } \\
\text { associações, grupos religiosos...? Passou a frequentar depois do curso? }\end{array}$ \\
\hline Ana: & Não. Eu não frequentava e nem passei a frequentar. \\
\hline Suzana: & $\begin{array}{l}\text { E eventos ligados ao bem estar da sua comunidade e de participação política? Você participava? } \\
\text { Passou a participar? }\end{array}$ \\
\hline Ana: & Não, também não. Nunca participei e... \\
\hline Suzana: & Fale um pouco, Ana, sobre as suas relações familiares antes \\
\hline Ana: & Assim... a relação, como assim? \\
\hline Suzana: & $\begin{array}{l}\text { Assim, como é que... como é que era o seu relacionamento com as pessoas da sua família, suas filhas, } \\
\text { seu... seu companheiro... Como é que era antes do curso, se depois do curso continua igual, ou se } \\
\text { mudou.... }\end{array}$ \\
\hline Ana: & $\begin{array}{l}\text { Não, continua na mesma. A mesma coisa, né? Antes ou depois, mesmo relacionamento. } \\
\text { Relacionamento bom com... principalmente com minhas filhas; é ótimo! }\end{array}$ \\
\hline Suzana: & $\begin{array}{l}\text { Como a sua decisão de participar do Programa foi recebida pela sua família? E como você acha que } \\
\text { seria recebida hoje? }\end{array}$ \\
\hline Ana: & $\begin{array}{l}\text { Foi... Meu esposo é que achou um pouquinho ruim, né? Porque ele nunca quer que saia de casa, né, } \\
\text { ainda mais com ela. Ele acha assim: “Ah, essa menina tem problema; cê vai sair...”. Hoje, igual } \\
\text { quando cê ligou ontem, né, ele já foi logo falando: "Ah, se for pra curso, vê lá o que é, porque tá } \\
\text { vendo que não dá pra sair, tem que levar a menina na natação". Hoje ela faz natação, né... Ele não } \\
\text { encarou muito bem quando cê ligou ontem, assim. Ele achou que era pra fazer um novo curso de } \\
\text { novo, né? Mas, aí, igual eu falei pra ele: “Mas se for curso, eu vou fazer. Não importa". }\end{array}$ \\
\hline Suzana: & $\begin{array}{l}\text { Você se sentia valorizada pela sua família, pelas suas atividades, é... profissionais, ou pela sua } \\
\text { dedicação à família e filhos, pelo seu envolvimento com as tarefas de casa ou outros, antes do curso? } \\
\text { E hoje, você se sente valorizada? }\end{array}$ \\
\hline Ana: & $\begin{array}{l}\text { Antes, sim. E hoje também. Eles dá valor, sim, muito isso. Eu sempre fui muito dedicada a casa, filhos, } \\
\text { né? }\end{array}$ \\
\hline Suzana: & $\begin{array}{l}\text { Ana, fale um pouco sobre como era a sua participação na educação e envolvimento nas atividades } \\
\text { das escolas dos seus filhos e como está agora: antes do curso e depois do curso. Seu envolvimento } \\
\text { com a... com a educação, com a escola das... das meninas. }\end{array}$ \\
\hline Ana: & $\begin{array}{l}\text { É, meu envolvimento com elas nas escolas sempre foi muito bom. Tudo que tem na escola eu } \\
\text { participo, né, dela. Sempre participei. E, hoje, eu continuo na mesma: participo do mesmo jeito... } \\
\text { com elas. }\end{array}$ \\
\hline Suzana: & $\begin{array}{l}\text { É... Existia diferença na participação da, na educação dos seus filhos? Na sua participação e na do pai } \\
\text { delas? E hoje? }\end{array}$ \\
\hline Ana: & $\begin{array}{l}\text { A diferença existe, assim, porque sempre... qualquer coisa que precise na escola, pra participar, } \\
\text { reunião, essas coisas, sempre sou eu, né, ele nunca participa de nada, né? E, hoje, ele faz a mesma } \\
\text { coisa: dever de casa, ele participa; reunião de escola, sempre quem vai sou eu. Ele não tem muita } \\
\text { participação nessas coisas, assim, não... }\end{array}$ \\
\hline Suzana: & $\begin{array}{l}\text { Certo... Antes do curso, o que você achava que determinaria o sucesso das suas filhas no futuro? E } \\
\text { depois do curso, o que que você acha? Ou seja, antes do curso, você achava assim: "Ah, o que... isso } \\
\text { vai representar sucesso profissional das minhas filhas no futuro". E depois do curso, mudou a sua } \\
\text { forma de ver? }\end{array}$ \\
\hline Ana: & $\begin{array}{l}\text { Não, eu nunca juntei uma coisa com a outra assim, não. Pra, assim: "Ah, eu vou fazer um curso e vai } \\
\text { ajudar minhas filha". }\end{array}$ \\
\hline Suzana: & Mas, assim, a sua forma de ver o sucesso. O que você acha que determina o sucesso das suas filhas? \\
\hline Ana: & $\begin{array}{l}\text { Assim, eu acho assim: o sucesso delas determina por elas mesma, né? Os estudos delas, que elas leve } \\
\text { a frente. Eu participando, assim, ajudando... né... aconselhando... Eu acho que só isso, mesmo. }\end{array}$ \\
\hline Suzana: & Mudou a sua forma de perceber isso antes e depois do Programa Mulheres Mil? \\
\hline
\end{tabular}




\begin{tabular}{|c|c|}
\hline Ana: & Não... mesma coisa. \\
\hline Suzana: & $\begin{array}{l}\text { Antes do Programa Mulheres Mil, quais os valores que você achava importante passar pras suas } \\
\text { filhas? E agora, depois do curso? }\end{array}$ \\
\hline Ana: & $\begin{array}{l}\text { Não, os valores, quer dizer assim: o respeito com os outros, ajudar... participação... participação em } \\
\text { grupos, né? É, eu sempre falei pra ela, né, que eu... o que a gente fala, o que a gente dá é o que a } \\
\text { gente recebe, né? Então... isso aí... acho que... não mudou nada não... Mesmo conselho que eu dava } \\
\text { antes, falo hoje. }\end{array}$ \\
\hline Suzana: & $\begin{array}{l}\text { Ana, você achava, antes do curso, que, por ser mulher, tinha oportunidades e tratamento diferentes? } \\
\text { E depois do curso? }\end{array}$ \\
\hline Ana: & $\begin{array}{l}\text { Não, também nunca achei isso... Nunca senti... nenhuma... Por ser mulher, ser tratada diferente, não. } \\
\text { Nunca me senti assim, não. Sempre me senti igual. }\end{array}$ \\
\hline Suzana: & Certo... \\
\hline Ana: & Antes e depois. \\
\hline Suzana: & Você acha que você e sua forma de ver o mundo mudaram depois de participar do Programa? \\
\hline Ana: & $\begin{array}{l}\text { Assim, aí... que sempre vive dentro de casa, né? Nunca tem participação em nada! Depois que eu } \\
\text { comec... depois que eu fiz o curso, sim, eu achei que... é outra pessoa, né? Que a mulher tem a vida, } \\
\text { pode ter a vida dela. Porque, antes, a gente fica pensando que depende só de marido, né, vive só ali... } \\
\text { Depois que eu fiz o curso, não. Eu vi que eu posso evoluir, que eu posso aprender. Que eu posso ter } \\
\text { minha vida lá fora, né? ((risos)). Mas, é isso. }\end{array}$ \\
\hline Suzana: & $\begin{array}{l}\text { Você se sente capaz de realizar coisas hoje que não se sentia capaz de realizar antes do curso? Por } \\
\text { exemplo? }\end{array}$ \\
\hline Ana: & $\begin{array}{l}\text { É... sei lá, acho que sim, né? Antes, eu achava, assim, acho que nunca conseguia fazer nada... por mim } \\
\text { só, né... E, hoje, eu acho que sim. Hoje, eu... eu acho que posso dedicar à casa e... fazer minhas coisas } \\
\text { e ter participação fora, também, né? Assim, faço meus artesanato, posso ter minha vida diferente, na } \\
\text { rua. Vender minhas coisas... É isso, né? Porque, às vezes, não fazia nada, achava ali: "Ah, minha } \\
\text { vidinha vai ser só essa". Depois que eu fiz o curso, a gente renova a vida, né? Renova, assim, né, pro } \\
\text { outro mundo. Acho, assim, que aprendeu... Achava que não ia aprender nada! Achava que nunca ia } \\
\text { aprender nada, né... ((risos))... artesanato. E aprendi, ué, aprendi muita coisa boa no artesanato. } \\
\text { Hoje, acho que eu me sinto mais coraj... Mais com... sei lá, autoestima... hoje, né? Por ter feito o } \\
\text { curso, ter participado... É isso, acho... Foi bem melhor, depois do curso. Fiquei bem melhor... Eu, é..., } \\
\text { eu tenho mais capacidade de evoluir mais. }\end{array}$ \\
\hline Suzana: & $\begin{array}{l}\text { Certo... qual você acha que foi a coisa, assim, mais importante pra você no curso? O que que ficou, } \\
\text { assim, de mais importante pra você? }\end{array}$ \\
\hline Ana: & $\begin{array}{l}\text { O aprendizagem, as amizades... Sei lá... Muita coisa boa, achei, no curso, né. A gente saiu, conheceu } \\
\text { muitos lugares. Tinha lugares aqui em Brasília que eu nunca tinha ido. Igual quando a gente foi lá na } \\
\text { Asa Norte, no IFB de lá... Esses passeio... Aprendi a mexer com artesanato, né, essas coisas. Foi muito } \\
\text { bom! Gostei muito do curso! Se houvesse outro, fazia de novo! }\end{array}$ \\
\hline Suzana: & Quer colocar mais alguma coisa? Falar mais alguma coisa? \\
\hline Ana: & $\begin{array}{l}\text { Não... Eu acho que não.... A única coisa, hoje, que eu tinha vontade, assim, mais é, igual eu falei pra } \\
\text { você, estudar. Terminar meus estudos, mas... Tenho um marido que tem a cabeça ruim, ainda acha } \\
\text { assim: de dia não conta, por causa que... só se for particular. E à noite, ah, acha que não. Que não dá, } \\
\text { que não sei o que... Que não tem um (incompreensível) que sai à noite... Única coisa que eu queria, } \\
\text { hoje, era só terminar, que eu ainda vou insistir nisso. Eu acho que esse ano, eu ainda vou ver se eu } \\
\text { consigo. }\end{array}$ \\
\hline
\end{tabular}


ANEXO C - Portfólio do Curso de Artesanato com Resíduos Sólidos

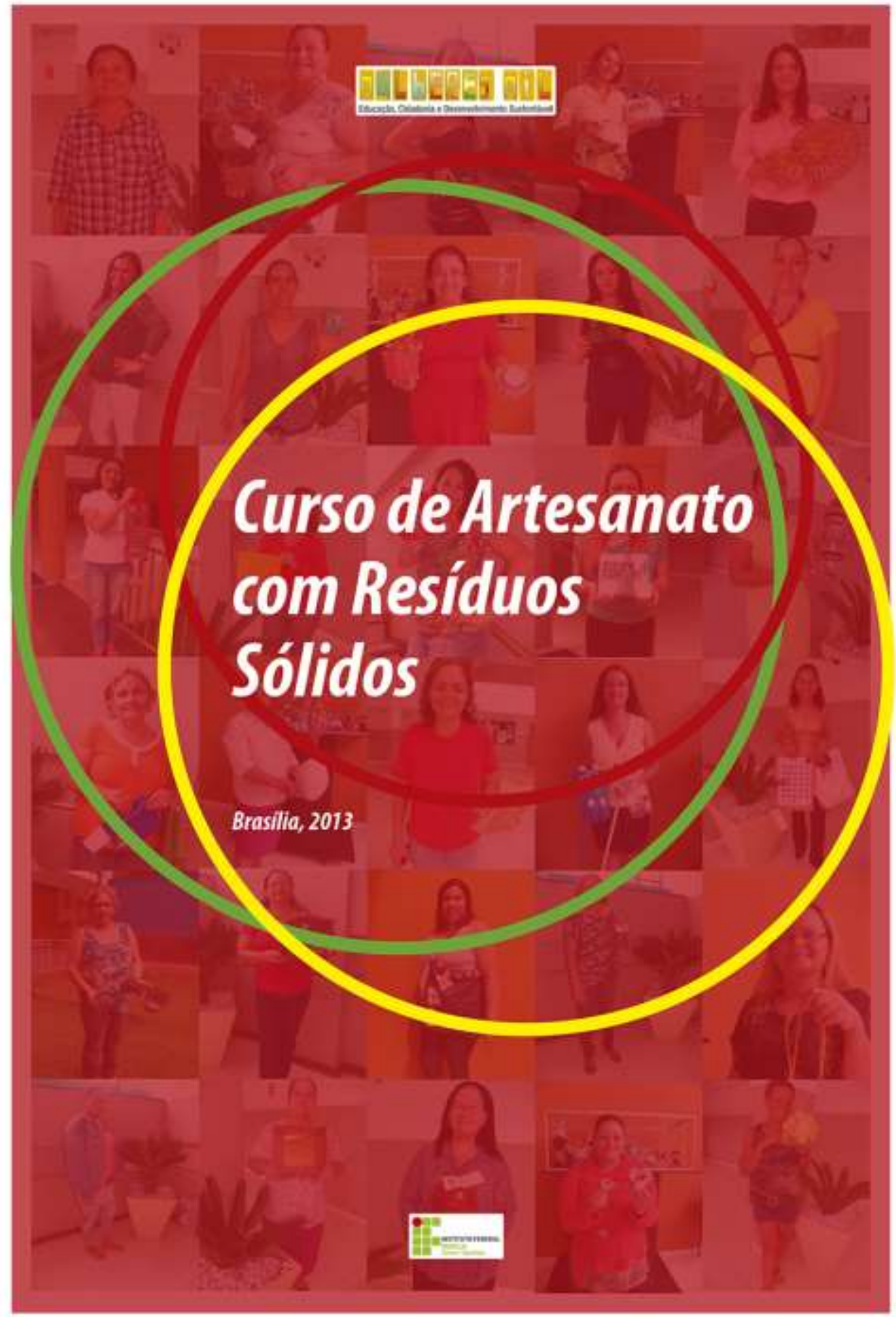




\section{Mulheres Mil}

OPrograma Mulheres Mil, Edvacaça Cidadania e Desemolvimento Sustentavel esta inserido no Plano Brasil sem Miséra e foi implementado em primeiro momento entre 2007 e 2011 em cooperaça como governo canadense evissa à formaçăo educcacionsl. profissional e odada cas mulheres desfororecidas principalmente da regisa norte e nordeste do Brasi.

A sistematizaçáo do projeto e as experiencias desenvalvidas pelos Institutos Federais de Educaçáo, Ciência e Tecrologia foram de tamanho sucesso que o Programa se espalhou por todo o Brasil.

Pensando nas muiheres em situą̧oes de vuinerabilidade social, o programa Mulheres Mil promeve o ctescimento humano e profissional dessas alunas, criando pontes para que elas ampliem seus conhecimentos produtivos e methorem suas vidas. 0 Programa conta com metodologia própria, estruturada em Acesso, Permanéncia e Exito, elaborada pela Secretaria de Educaça Profissional e Tecnokogica (Setec) do Ministério da Educaçăa.
0 campus Taguatinga do IFB - Instituto Federal de Brasilia ofere. ceve em 2013 duas turmas do curso de Arteganato com Residuos Solididos pelo Programa. A proposta do curso foi capacita-las para elaborarem peças artesanals com materiais descartados e tambeen dar a elas ferramentas e instrumentos para a sua inserço secioprofissional, por meio de aulas nas áreas de saùde, genero, didadania, informática e habilidades de relacionameato.

Para a permanência das alunas, o programa contou com diversos estimulos. Umas das iniclativas foi a criaçảo da beinquedoteca "Brincadeiras Mil" para fazer o atendimento aos filihos das alunas que tenham idade entre 3 e 8 anos. Com um proposta inovadora, a trinquedoteca fadilitov 0 acesso e a permanència da alunas máes, proporcionando a elas a tranquilidade para frequentarem suas aulas com a certera de que svas crianças estāo em um ambiente seguro. Alem da Coordenadora do programa Mulheres Mili, duas estagíálias da área de Pedagogia acompanham as crianças.

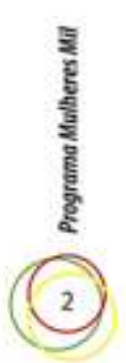

\section{Artesanato com Resíduos Sólidos}

Na turma $A$, as aulas iniciaram no dia 19 de março e finalizaram no dia 03 de dezembro de 2013.

Na turma B, as aulass iniciaram no dia 21 de março e finalizaram no dia 28 de novembro de 2013.

\begin{tabular}{|c|c|c|}
\hline \multicolumn{3}{|c|}{ Matriz Curricular do Primeiro Semestre } \\
\hline Compocente & Gegaboraina(h/a) & Docente \\
\hline Acolhimento & 10hía & Suzana Guerra \\
\hline Introdoxào as artesanats & 16 h/3 & Szana Guerna \\
\hline Habilidades deredacionimento & $20 \mathrm{~h} / \mathrm{a}$ & Guilherme Cari (Cimara dos Deputados) \\
\hline Antesanato com tesiduss sólisos 1 & 3Shia & $\begin{array}{l}\text { Camila Forseca (10h/a) / Rosalice Rabelo (10h/a) } \\
\text { Suzana Guerra (10h/a) / Thestese Hofmmn - Uns (5h/a) }\end{array}$ \\
\hline Constructo deginero & $24 h / 2$ & José Olinet \\
\hline Iotal Primeio Semestre & 10Sh/a & \\
\hline \multicolumn{3}{|c|}{ Matriz Curniailar do Segundo Semestre } \\
\hline Compocente & Gegathodina (h/a) & Docente \\
\hline Introbacaio d Informitica & $15 \mathrm{~h} / \mathrm{a}$ & Vanessa Mendonça \\
\hline Antesanato com residuxs sólibos 2 & 40h/a & $\begin{array}{l}\text { Juliana Rangel (20h/a) / Moema Carvalho (5h/a) } \\
\text { Rosalice Rabelo (10h/a) / Sarana Guerna (5h/a) }\end{array}$ \\
\hline Sade no basil & $15 \mathrm{~h} / \mathrm{s}$ & Diana Marinho \\
\hline Mulherese Cidadaria & 15hra & Moema Carvalho \\
\hline Empreendedorismo eccooperativismo & $15 \mathrm{~h} / \mathrm{a}$ & Frandisco Nunes \\
\hline Custose preyos & $15 \mathrm{~h} / \mathrm{a}$ & Frandisco Nunes \\
\hline Projeto find & $20 \mathrm{~h} / \mathrm{a}$ & Suzana Guents \\
\hline Iotal Segundo Senestre & $135 \mathrm{~h} / \mathrm{a}$ & \\
\hline Total do curso & $240 \mathrm{~h} / \mathrm{a}(200 \mathrm{~h})$ & \\
\hline
\end{tabular}

\section{Comissão do Mulheres Mil no campus Taguatinga do IFB}

\section{Gestora Local}

Suzana Curi Guerra, docente do IFB, dedica(äo exclusiva

\section{Estagiários de Pedagogia}

- JoséWilami de Carvalho Silva (abrite maio)

- Maria do Socorro Martins de Sousa (setembro a dezembro)

- Paula Alves Pereira (junho a derembro)

- Rebeca Lillian Jardim Guimarảes (abril a agosto)

\section{Equipe Multidisciplinar}

- Ana Maria Soares Freite P. Leal, Assistente Social

- Jullana Rangel de Morais Pimentel, docente contrato temporário

- Maristela Lopes Rodrigues de Lacerta, Técnica em Assuntos Educacionais

- Moema Carvalho Lima, docente, dedicarăo exclusiva

- Rosalice Rabelo Santana, docente, contrato temporário 


\section{Mapa da Vida}

É uma ferramenta no processo de construção do Programa Mulheres Mil e objetiva criar oportunidade e ambiente para a troca de experiências de vida das mulheres, para que elas possam ser compartilhadas e entăo devidamente registradas, validadas e valorizadas.

0 método potencializa o sujeito como autor da história da sua vida, da de seu grupo, instituição ou comunidade, ou seja, as experiências podem ser narradas e registradas por seus protagonistas.

A construçāo do mapa da vida estimula pessoas a organizar sua própria história numa cronologia que possibilite que cada uma visualize e apresente sua trajetória global. Por outro lado, coloca o sujeito diante da perspectiva de fazer escolhas e selecionar o que quer contar e registrar, revelando os fatos marcantes, as rupturas e as pessoas significativas.

Na turma A, o mapa foi feito no dia 19 de março, e na turma B, no dia 21 de março. Contamos com a presença da coordenadora do Programa Suzana Guerra, a professora Moema Carvalho e a assistente social Ana Maria Freire.
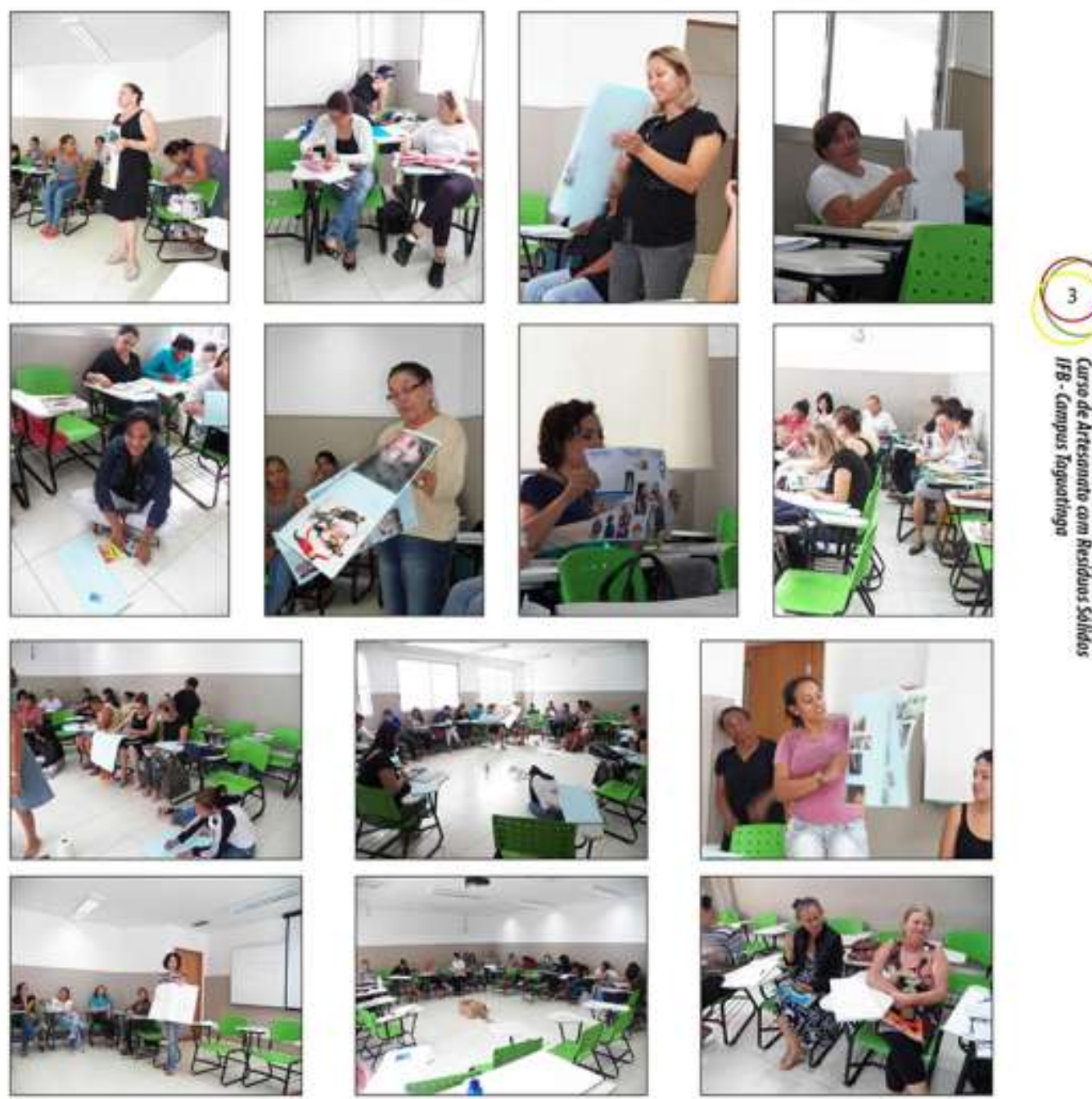

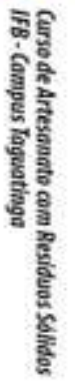




\section{Comemorando a Páscoa}

Nos dias 26 (turma A) e 28 de març (turma B), fizemos uma oficina de reaproveitamento de tubos de papel higienico e cascas de ovos para fazer uma lembrancinha muito fófa para a Páscoa com a professora Suzana Guerra.

As alunas são tão criativas que outros projetos surgiram!

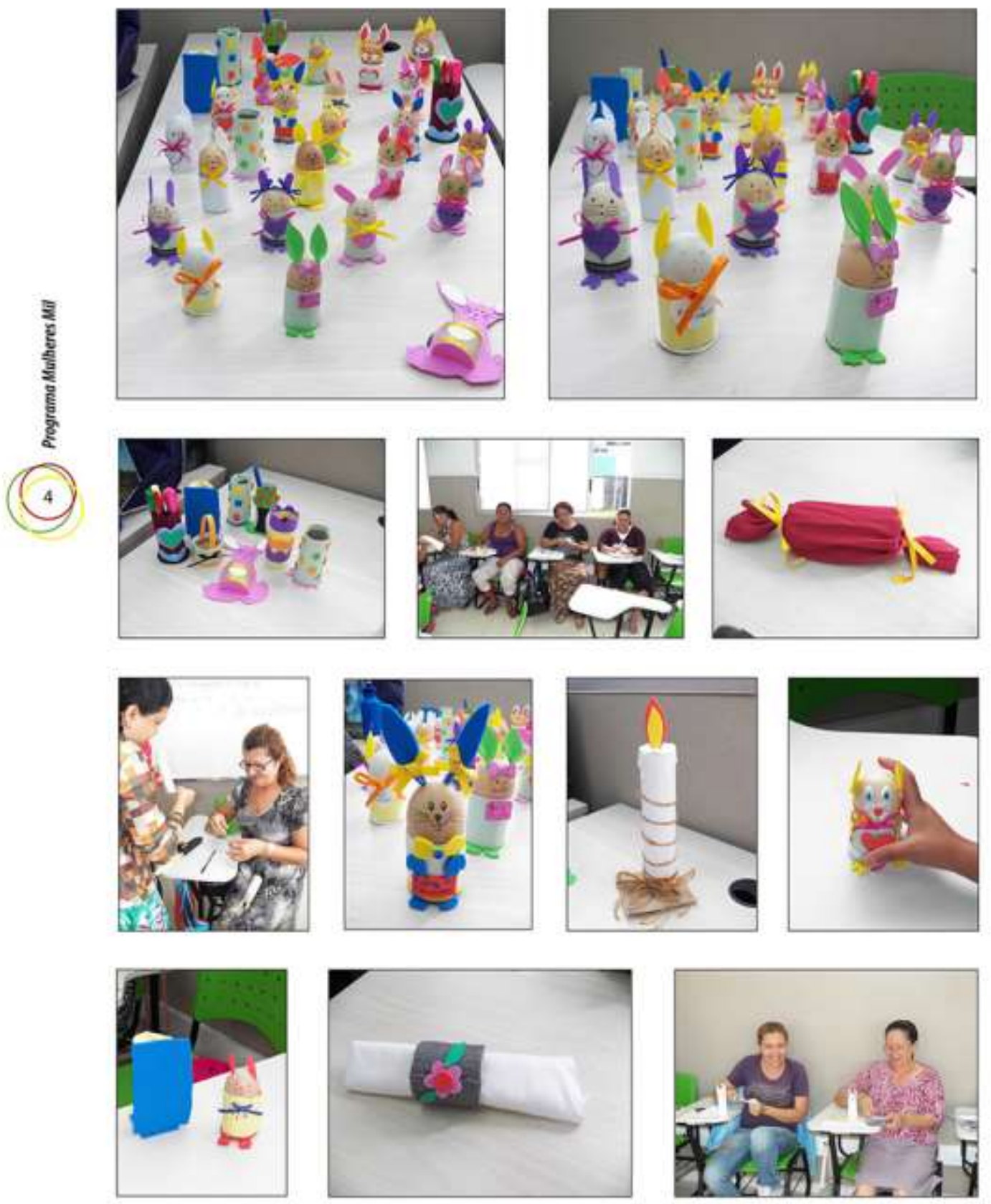




\section{Papel Maché}

O papel machê é uma técnica milenar que permite fazer objetos utilitários e de decoraçăo, com inúmeros formatos e tamanhos. Esta técnica, além de ser extremamente versátil, é também muito barata pelo fato de que boa parte do material que se utiliza ser reaproveitado: jornais, revistas, listas telefónicas, papeis descartados e papelăo.

A professora Viviane Aronowicz foi a responsável pelas duas aulas de papel machè, que aconteceram nos dias $6 \mathrm{e}$ 13 de abril. Elas aprenderam a técnica de forrar balāo, fizeram um porta guardanapo e receberam uma apostila completa da técnica. Estas foram as primeiras aulas conjuntas com as turmas A e B.
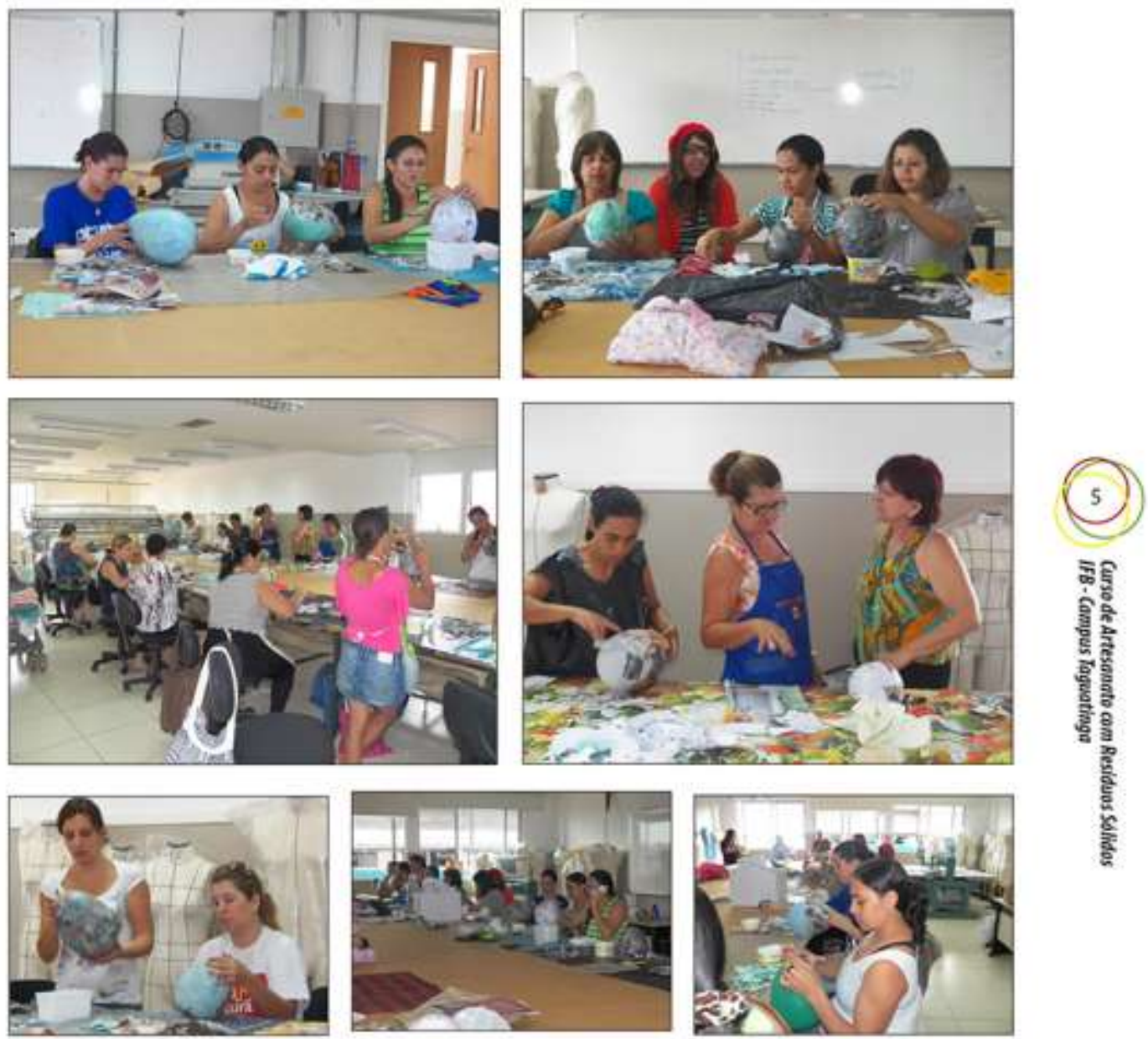

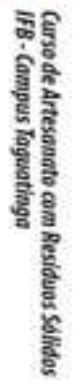
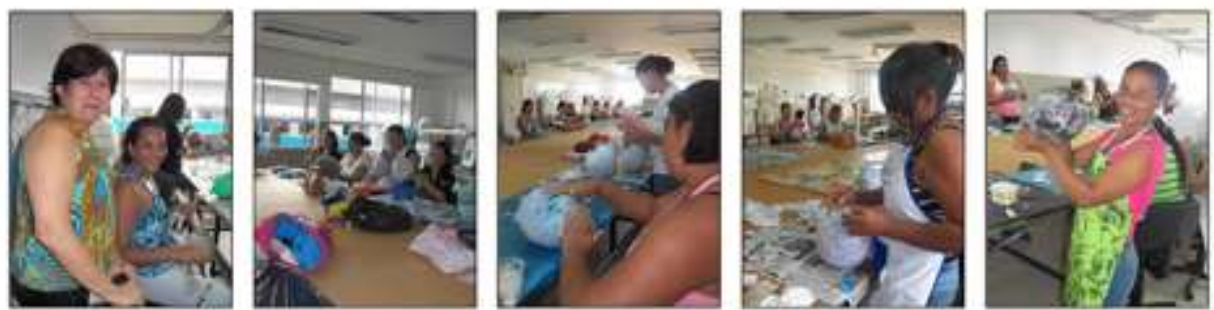


\section{Papel encadernaçâo Artesanais}

As Mulheres Mil estiveram na Universidade de Brasilia - UnB, nos dias 4 (turma A) e 11 de maio (turma B) e foram recebidas pela professora de Artes Thérèse Hofmann, pesquisadora da área de Materiais em Arte e Papel Artesanal, e pelos estagiários que a auxiliam.

Após uma breve aula sobre o papel e os primeiros suportes utilizados pelo homem para registro de sua história, as alunas aprenderam a fazer papel artesanal utilizando como matéria-prima cédulas de real trituradas, descartadas pelo Banco Central, bitucas de cigarro, tronco de bananeira, papel descartado, entre outros. Elas também aprenderam uma tẻcnica de encadernaçāo e fizeram, cada uma, um bloco de anotaçōes.

A reutilização de papel moeda e de bitucas de cigarro é resultado das pesquisas realizadas pela Professora Thérèse e sua equipe, e sấo patenteadas pelo Instituto Nacional de Propriedade Industrial - Inpi.
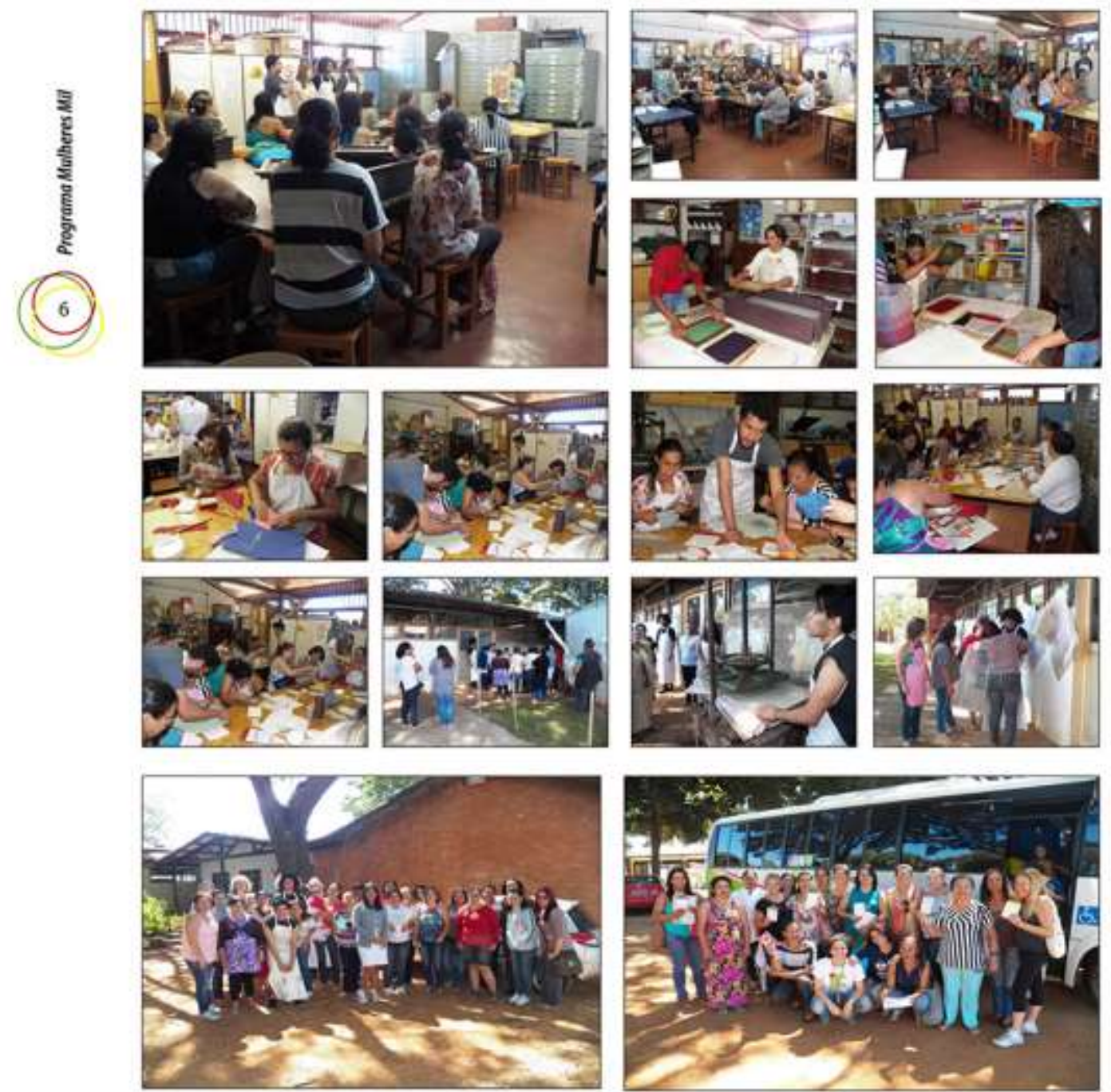


\section{Reaproveitamento de Malha}

Nos dias 07/05 (turma A) e 09/05 (turma B) foi a vez da assistente social Tãmara Miranda ensinar uma técnica de reaproveitamento de malha.

Ela ensinou a fazer pulseiras e colares de malha com uma trança de 5 pontas:

A aula foi um sucesso e todas sairam da aula com um acessório nowo!
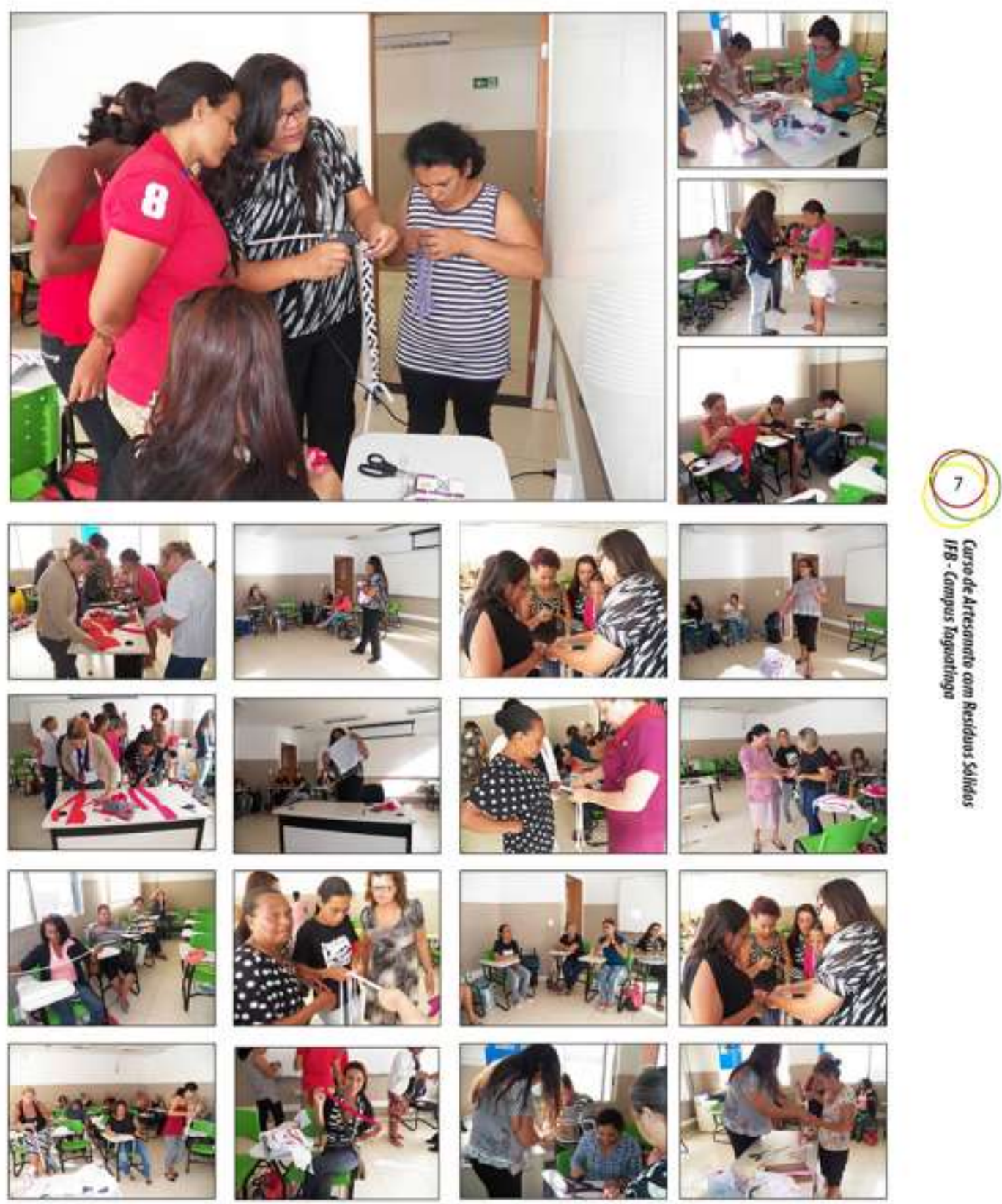

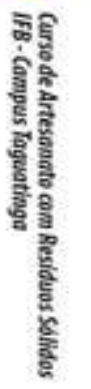




\section{Buquê de Garrafa Pet}

A professora Camila Fonseca trouxe um projeto inovador para as Mulheres Mil: fazer buquês com garrafas pet! Em grupos, elas definiram qual os modelos de flores que gostariam de representar e começaram a cortar as garrafas. Depois de cortadas, modelaram as partes com fogo. Para a finalizaçăo, elas usaram tintas e montaram os buqués. A oficina aconteceu nos dias 18 e 25 de maio.

0 resultado ficou excelente!
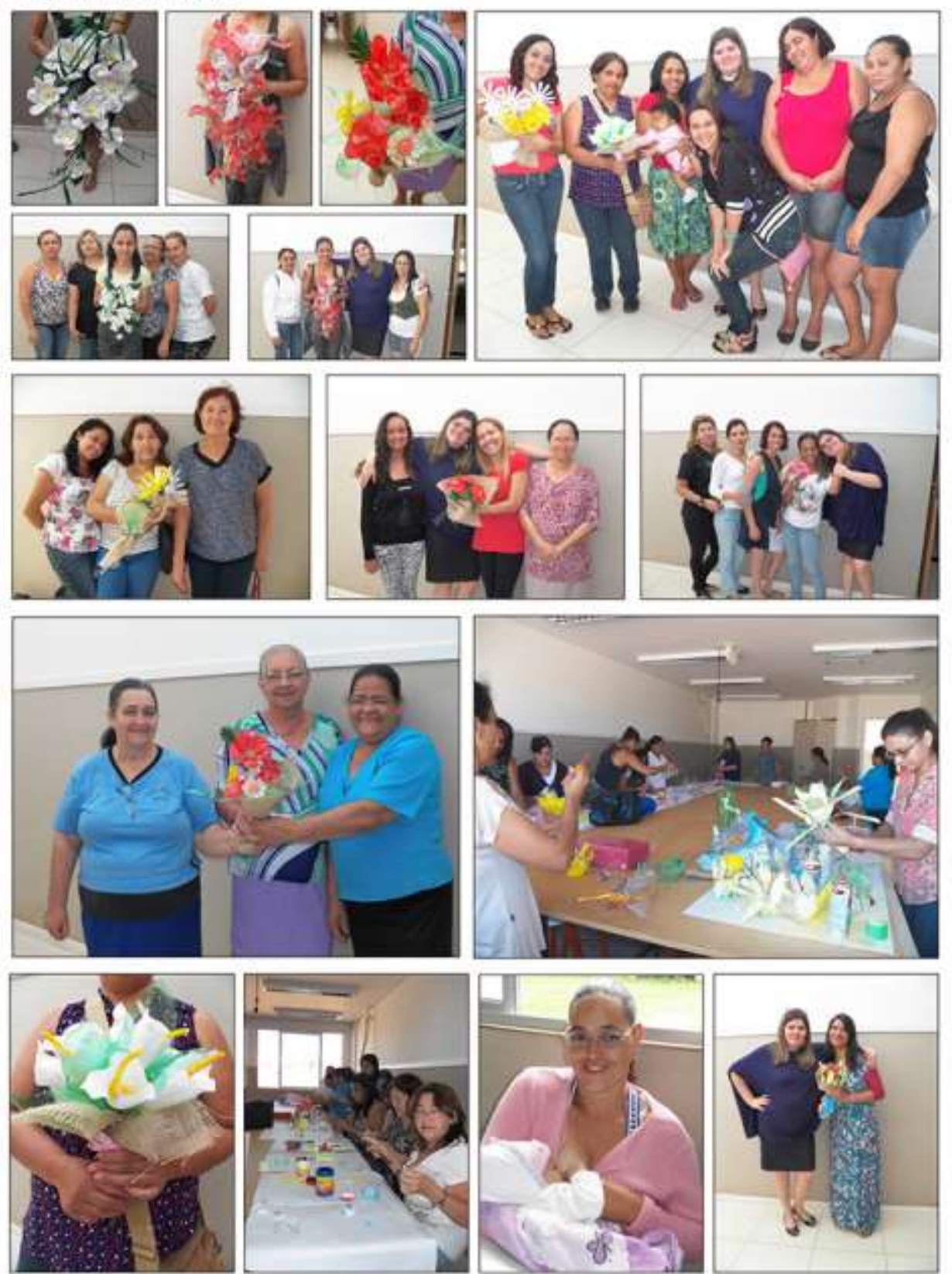
Desafio: Casa de Bonecas com Jornal

A professora Suzana Guerra lançou um desafio: as alunas deveriam fazer, em grupos, uma casa de bonecas utilizando somente jornal, cola e grampeador. 0 objetivo era estimular a criatividade e a busca de soluç̧óes.

Alguns grupos foram além e colocaram inclusive móveis e bonecos na casa.

0 resultado da atividade, que ocorreu nas últimas aulas da componente "Introduçăo ao Artesanato" no mês de junho, foi muito criativo!
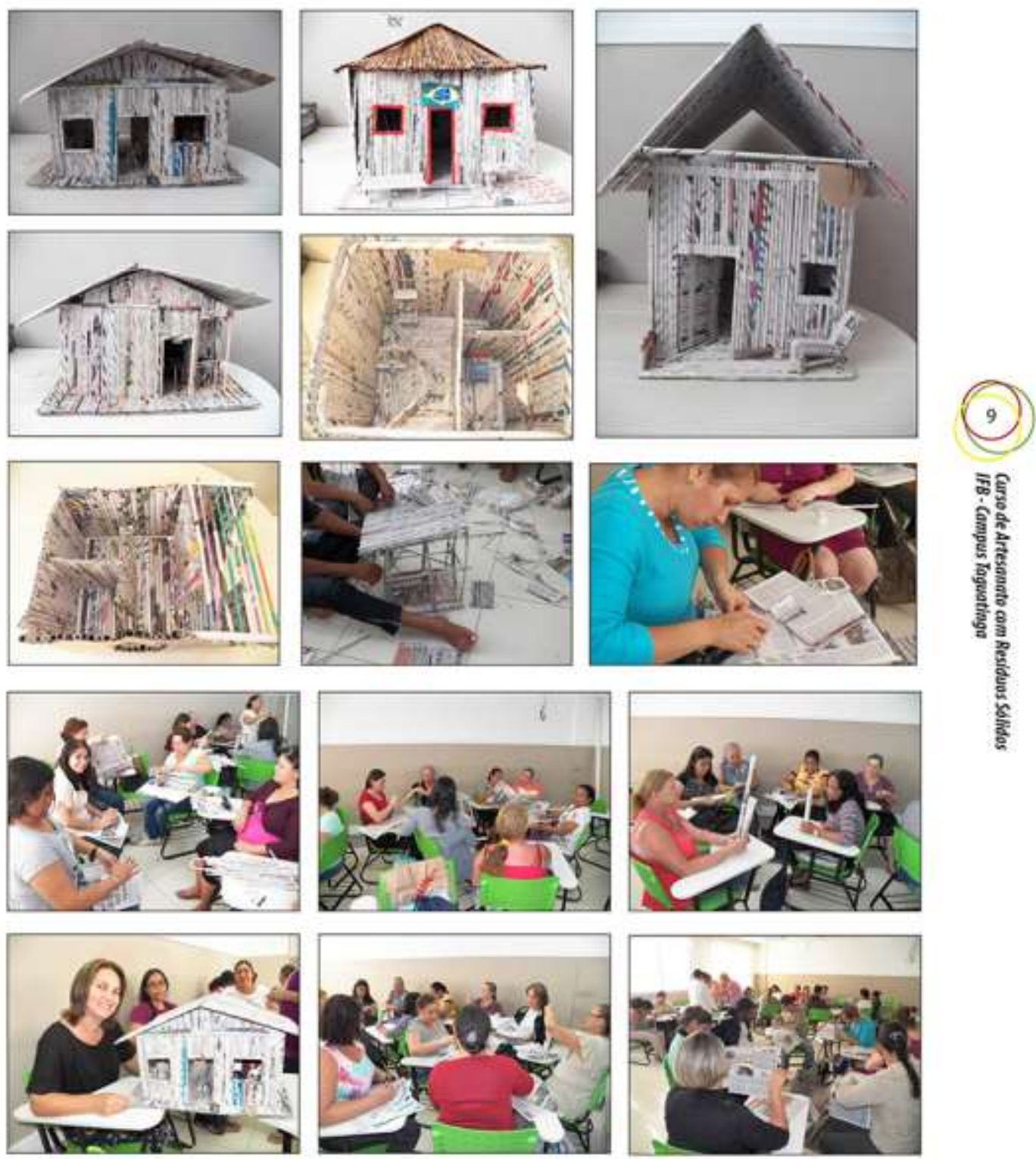

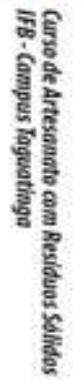




\section{Bolsa de Banner}

A professora Rosalice Rabelo ensinou para as alunas um modelo de bolsa feito com banner (lona vinilica) de propaganda.

As alunas cortaram o banner de acordo com o molde, furaram e costuraram com agulhas e tapeçaria e de crochê. Depois, cada uma enfeitou sua bolsa com fuxicos, flores, desenhos e pinturas.

As aulas ocorreram nos dias 08 e 22 de junho.
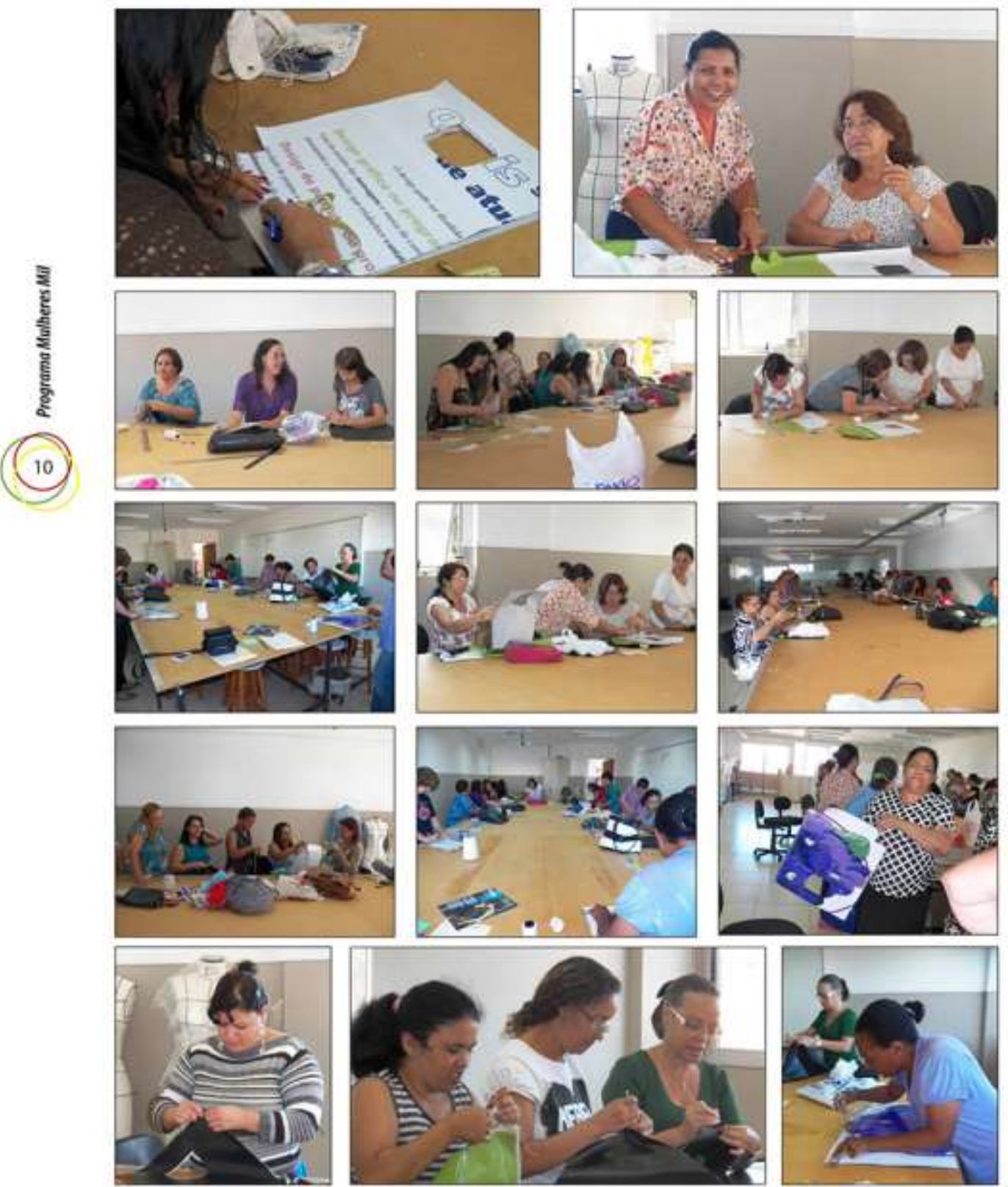


\section{Flor de Saco de Cimento}

Depois das férias, no dia 17/08, as alunas aprenderam a fazer flores de saco de cimento com a professora Moema Carvalho.

O saco do cimento é extremamente resistente, pode ser lavado, e após os acabamentos fica parecendo metal. As flores das Mulheres Mil ficaram lindas!!
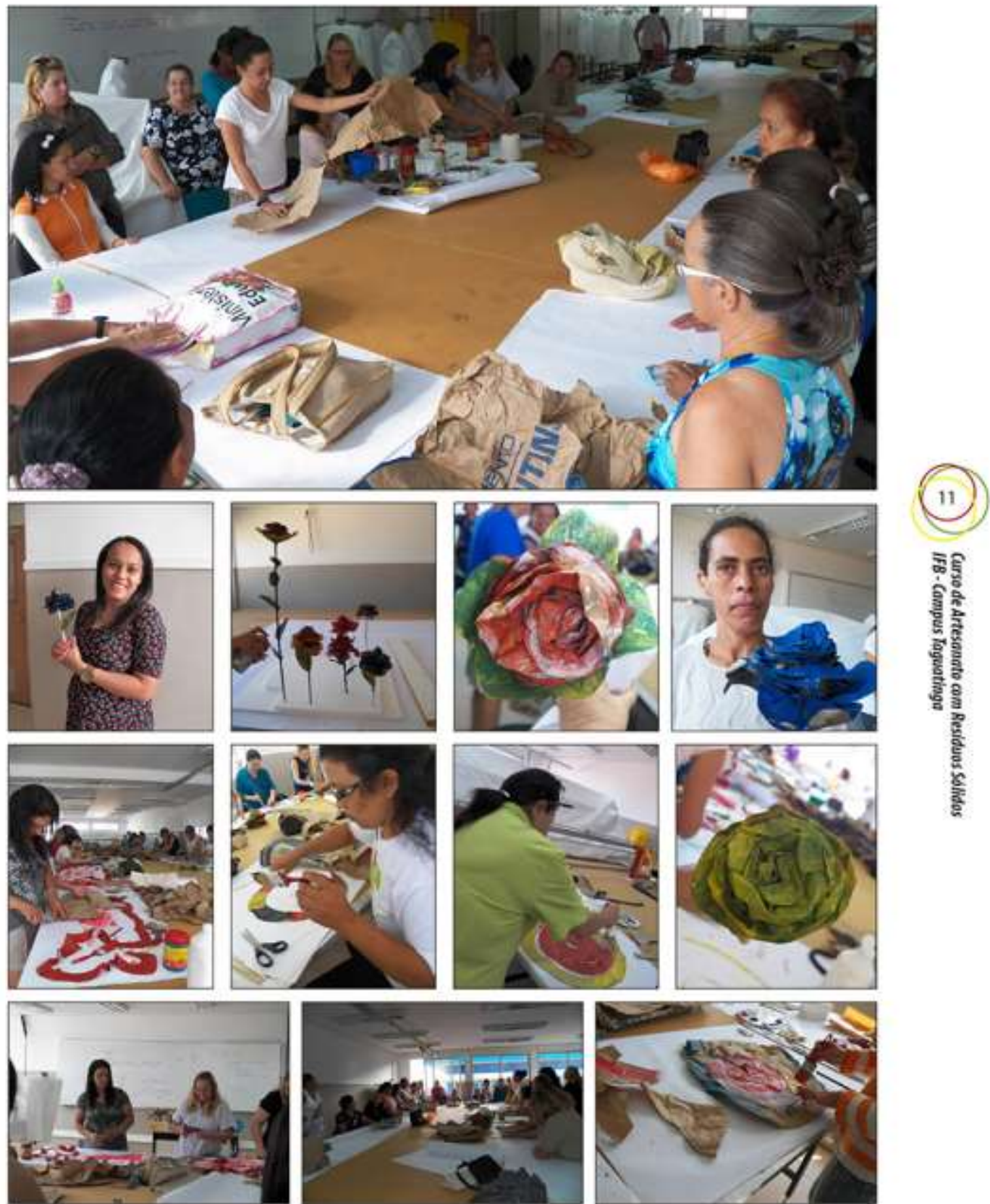

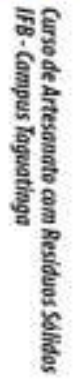


Reutilizaçâo de Espelhos Quebrados

No dia 21 de setembro a professora Rosalice Rabelo trouxe os parceiros da Ong "Tempo Eco Arte", Mirela e Glauber para ensinarem a fazer molduras em espelhos danificados.

A técnica utiliza papelăo, jornal e outros papéis descartados para fazer o revestimento dos espelhos.

A oficina foi um sucesso, as Mulheres Mil amaram!

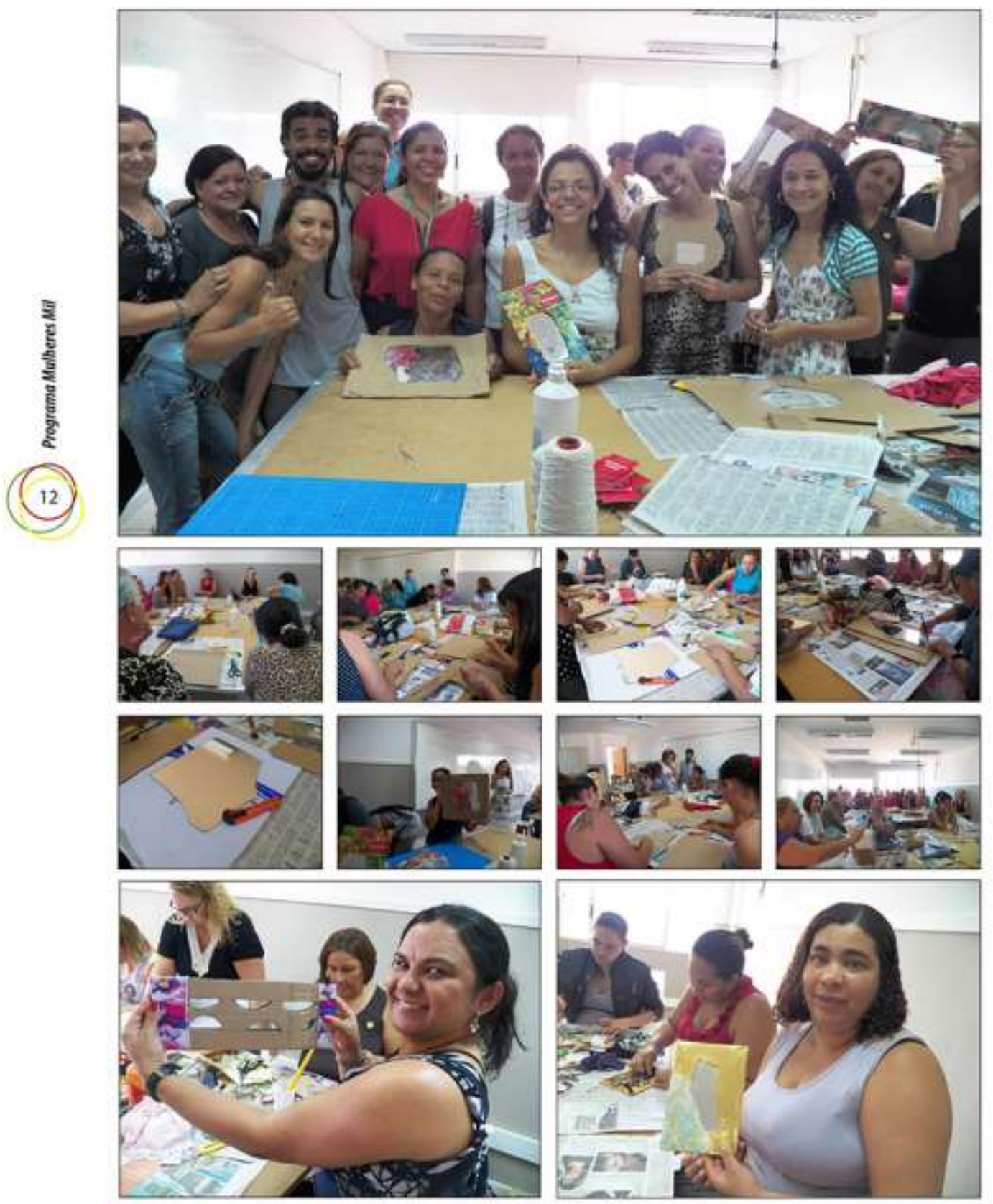




\section{Customização}

Por meio de algumas técnicas, a professora Juliana Rangel ensinou as Mulheres Mil a customizarem roupas.

Os recursos de tie dye (técnica de tingimento artistica), aplicaç̄es, bordados e estampa com giz de cera proporcionaram às alunas formas de reutilizar uma peça de roupa sem uso ou danificada.

As aulas da professora Juliana Rangel ocorreram nos dias 05/10, 26/10, 09/11 e 23/11.
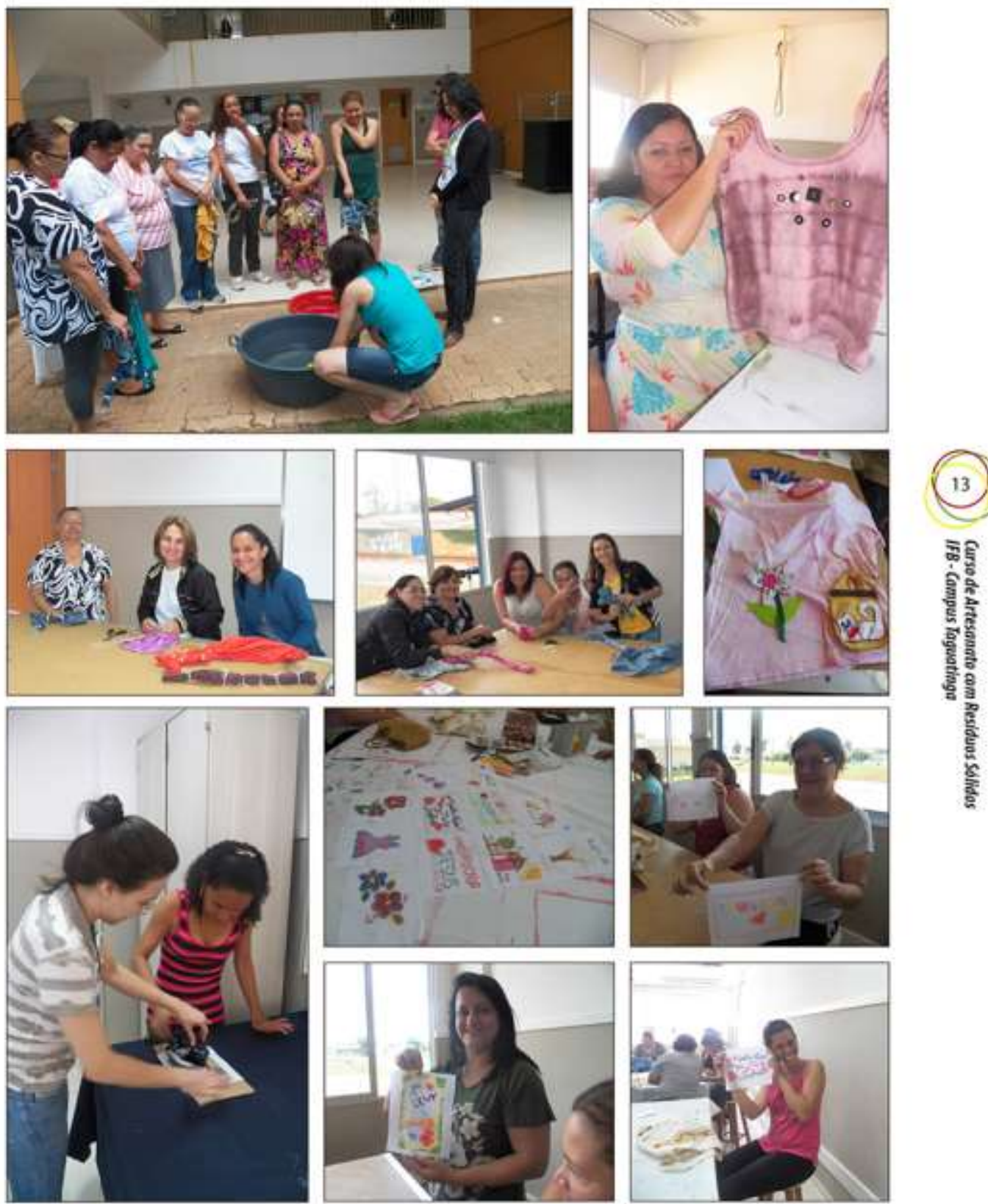

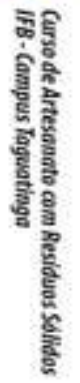




\section{Sacolas de Jornal}

Com o tema da Lei Maria da Penha, a professora Moema Carvalho trabalhou sacolas de jornal com as alunas na componente" "Mulheres e Cidadania". Este encontro ocorreu no dia 19 de outubro.

As sacolas de jornal săo baratas e muito resistentes, além do fato de ficarem lindas!
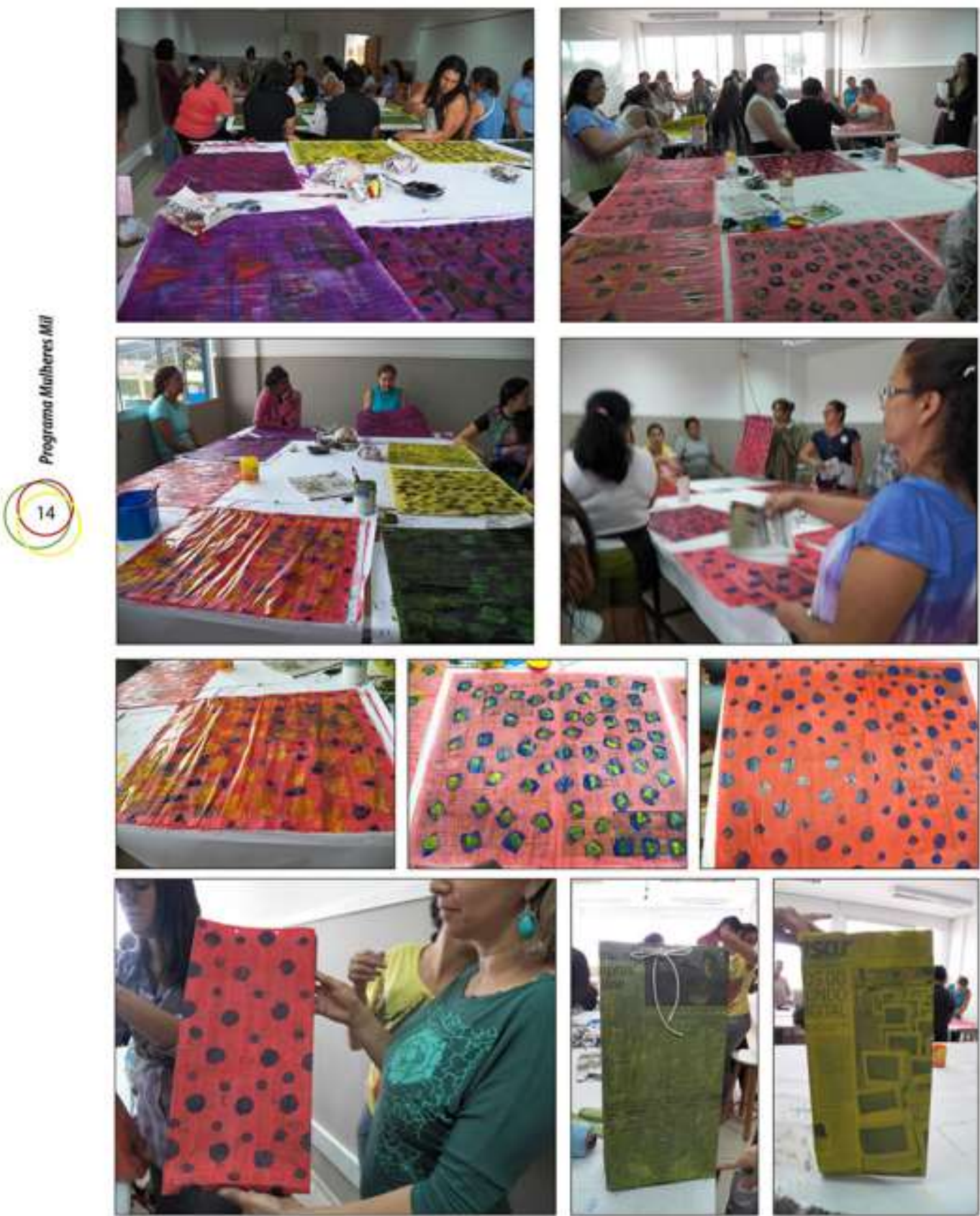


\section{Sacolas de Jornal}

Com o tema da Lei Maria da Penha, a professora Moema Carvalho trabalhou sacolas de jornal com as alunas na componente" "Mulheres e Cidadania". Este encontro ocorreu no dia 19 de outubro.

As sacolas de jornal săo baratas e muito resistentes, além do fato de ficarem lindas!
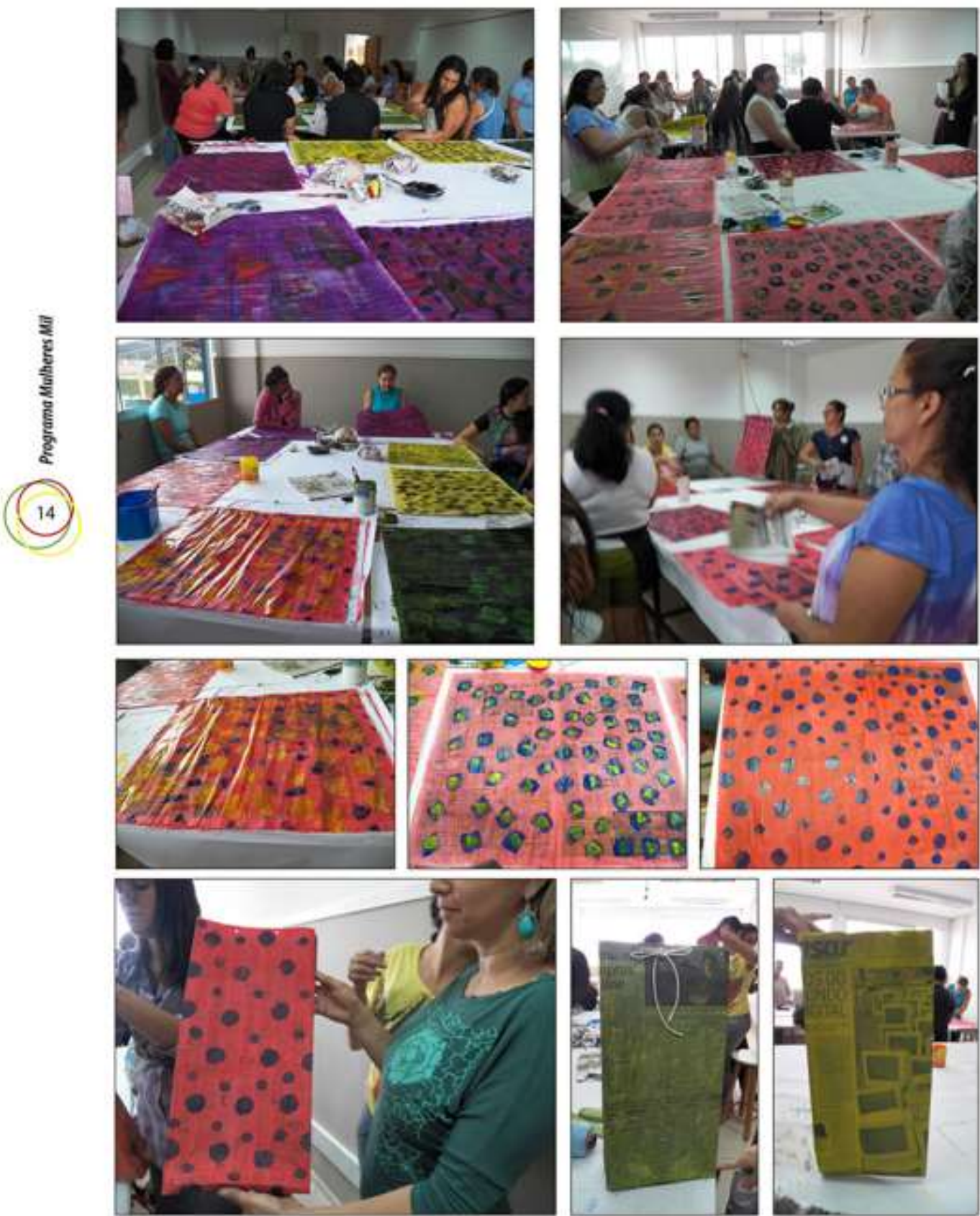
Guirlandas de Natal

A professora Moema Carvalho trabalhou o tema Direitos Humanos associado à confecção de guirlandas de natai no dia 16 de novembro.

Elas foram confeccionadas utilizando sobras de tecidos e aviamentos.

As guirlandas ficaram expostas na Reitoria do IFB durante o periodo natalino.
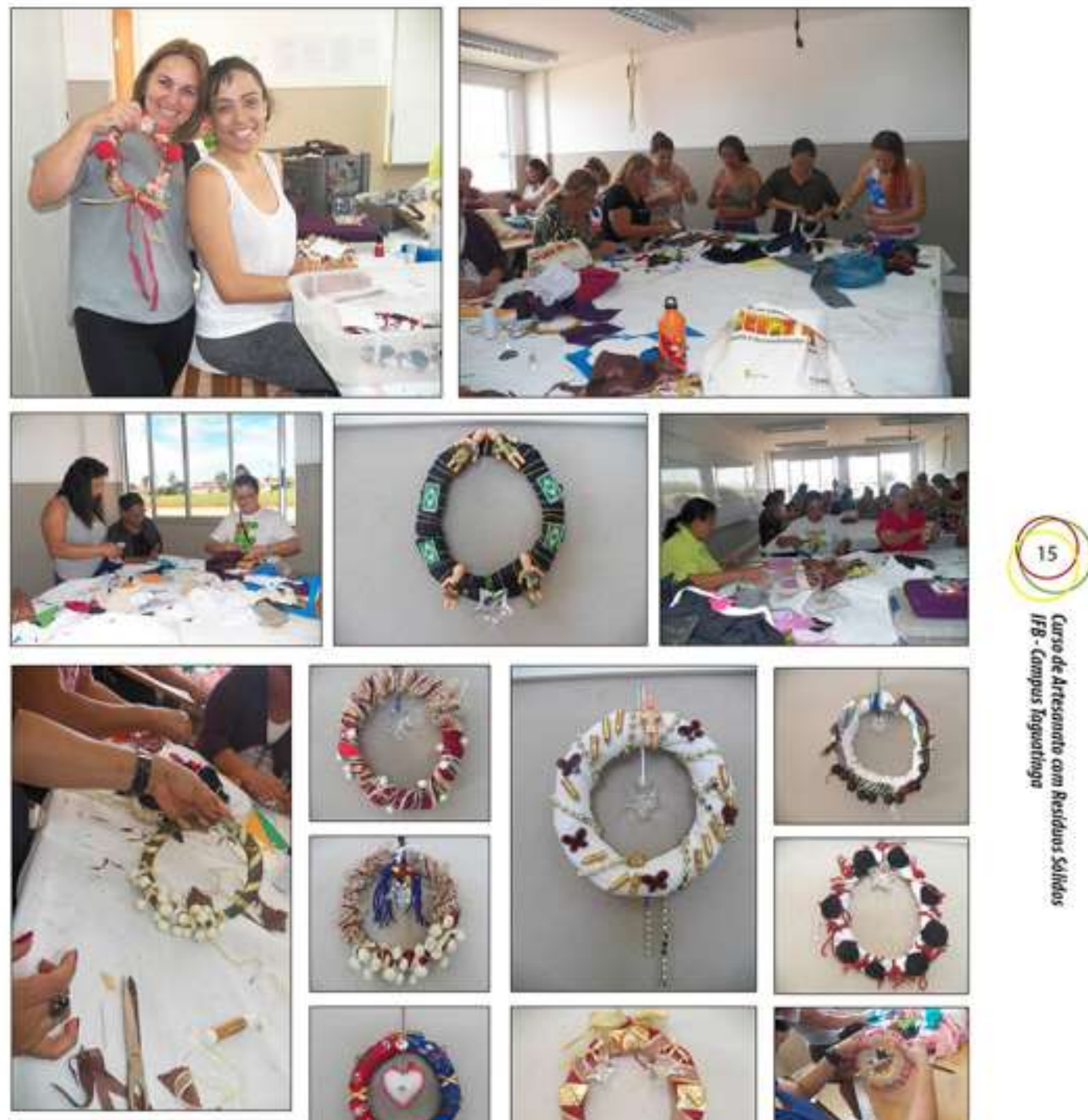

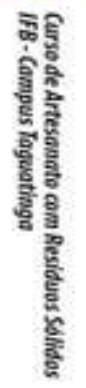
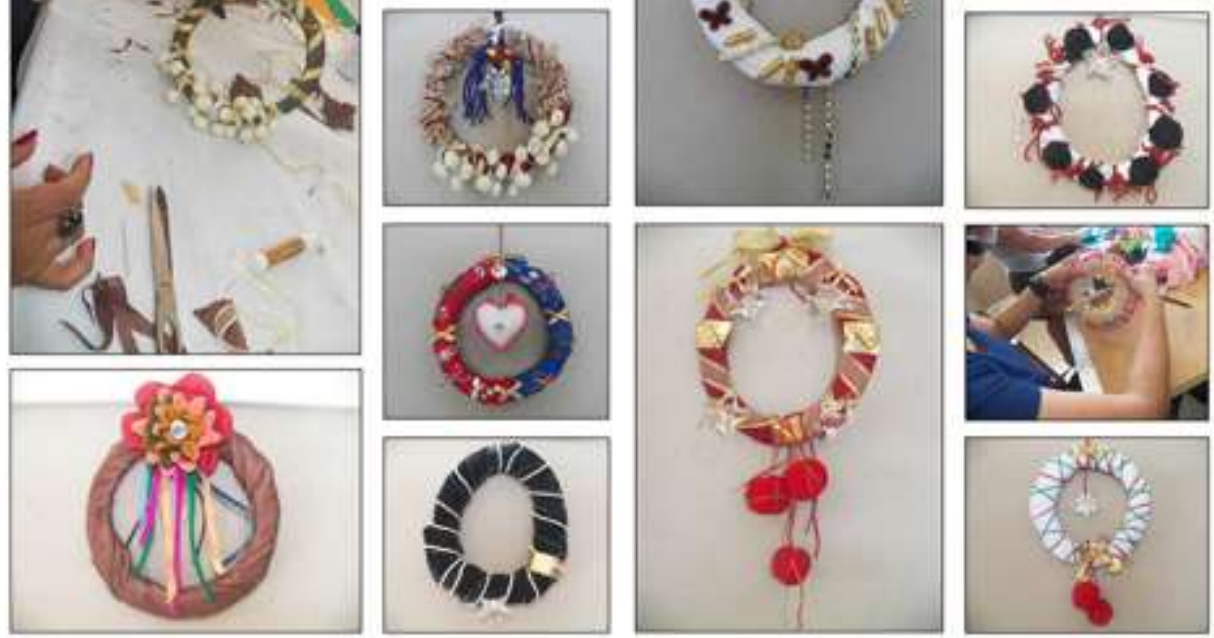


\section{Faces da Mulher no Cinema}

Para a componente "Construçăo de Gènero", ministrada pelo professor José Oliver, as Mulheres Mil fizeram representaçōes artesanais inspiradas nos filmes que assistiram durante as aulas.

Esta componente ocorreu nos meses de maio e junho.

Os filmes a que as alunas assistiram foram: Agora (Alexandria). Direçåo: Alejandro Amenábar. Espanha, 2009; A cor pứrpura. Diresăa: Steven Spielberg. Estados Unidos, 1985; Histórias cruzadas. Direçäo: Tate Taylor. Estados Unidos, 2011; Tudo sobre minha mãe. Direçăo: Pedro Almodóvar. Espanha, 1999; 0 céu de Suely. Direçāo: Karim Ainouz. Brasil, França, Alemanha, 2006; A excêntrica famllia de Antonia. Direçào: Marleen Gorris. Paises Baixos, 1995; e Rosa Luxemburgo. Direçäo: Margareth Von Trotta. Alemanha, 1986.
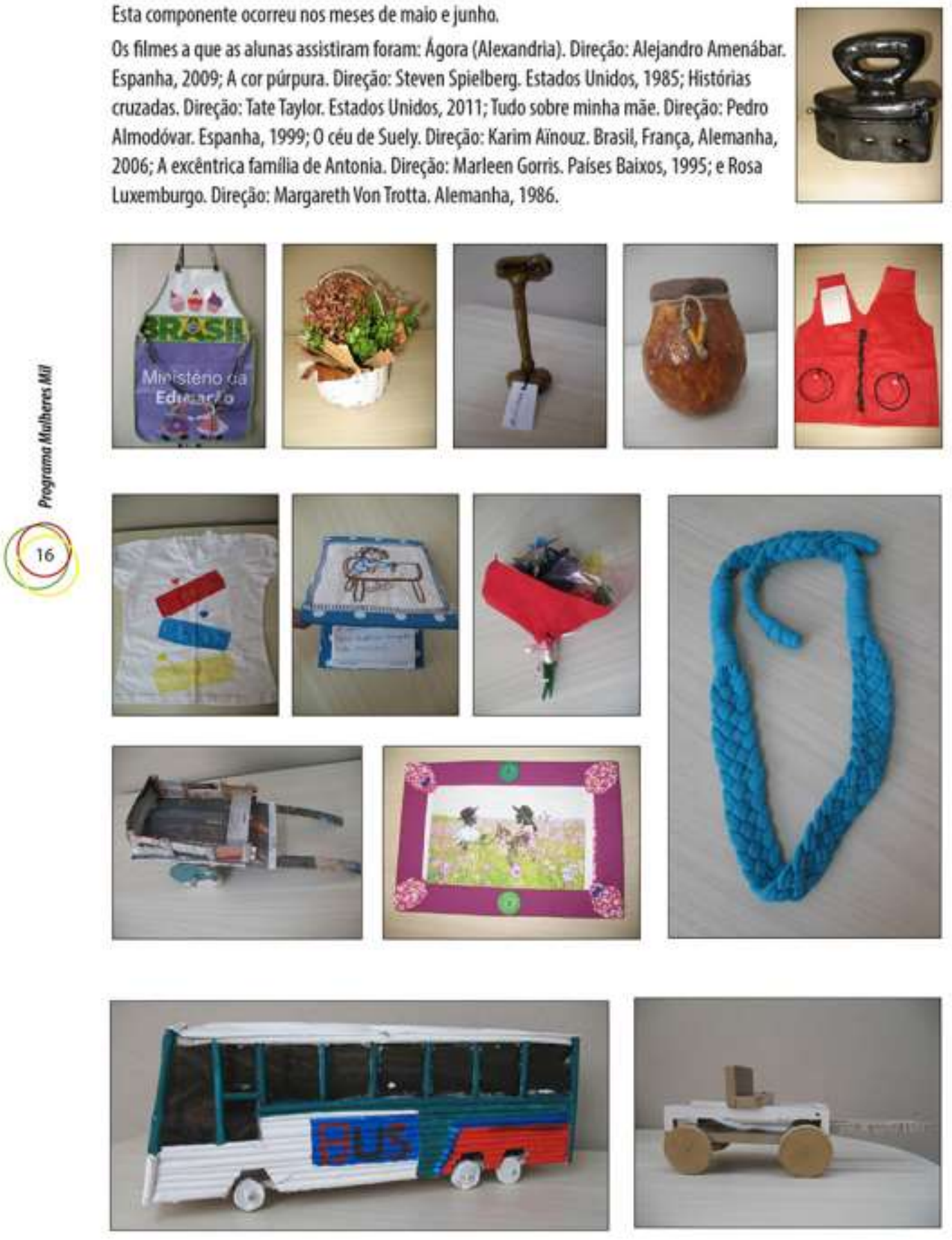
Sauide no Brasil

A professora Diana Marinho, na componente "Saúde no Brasil", solicitou às alunas que fizessem uma peça artesanal no tema das aulas. Esta componente foi realizada no més de agosto.

Foram abordados cuidados com a saùde da mulher, reproduçāo, doenças tropicais, entre outros assuntos.
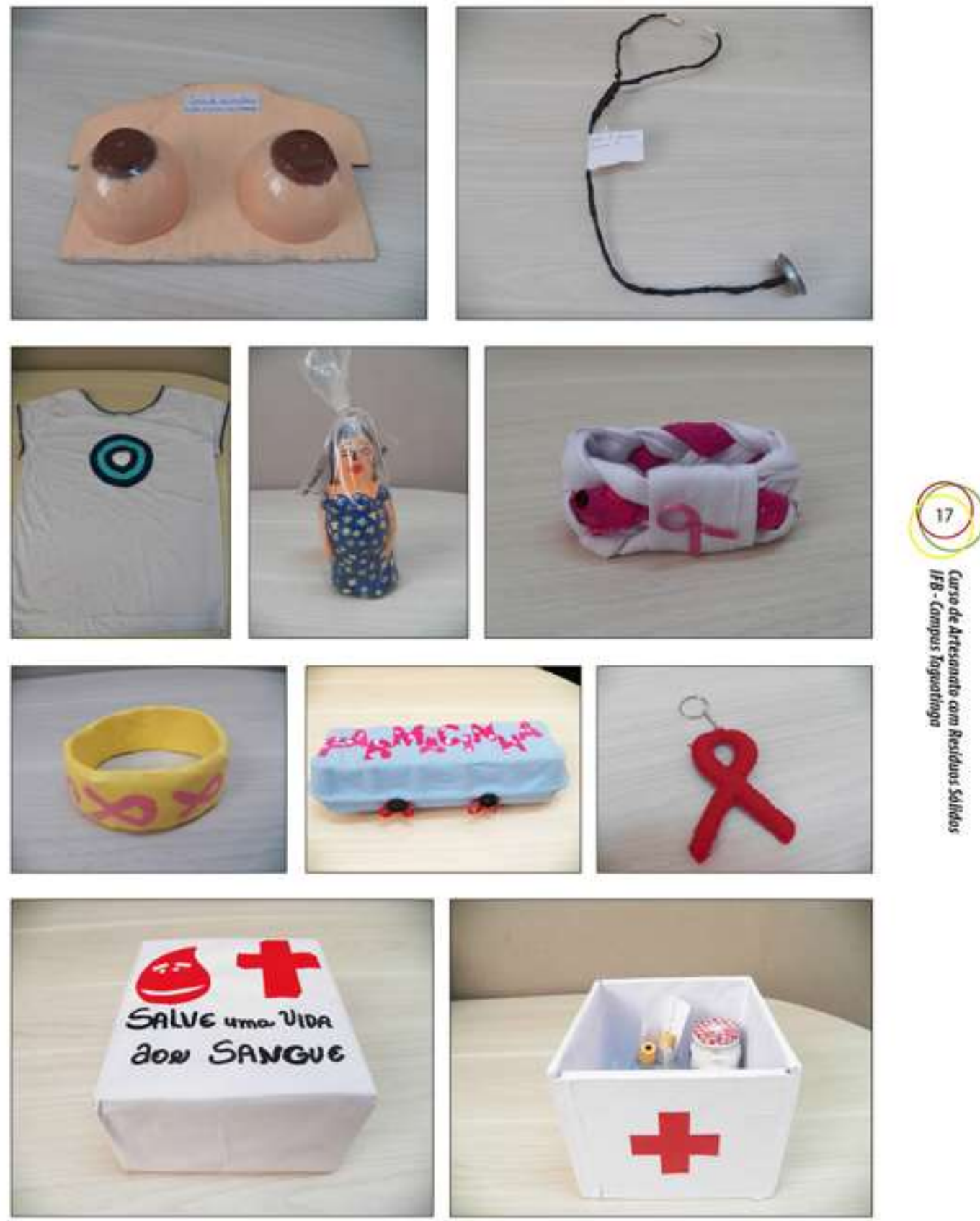
Introdução à Informática

Nesta componente, que ocorreu em setembro, as Mulheres Mill aprenderam o básico de informática, com foco em pesquisa na internet com a professora Vanessa Mendonça.

Como resultado da componente, foi solicitado que pesquisassem técnicas artesanais na internet e as aplicassem.

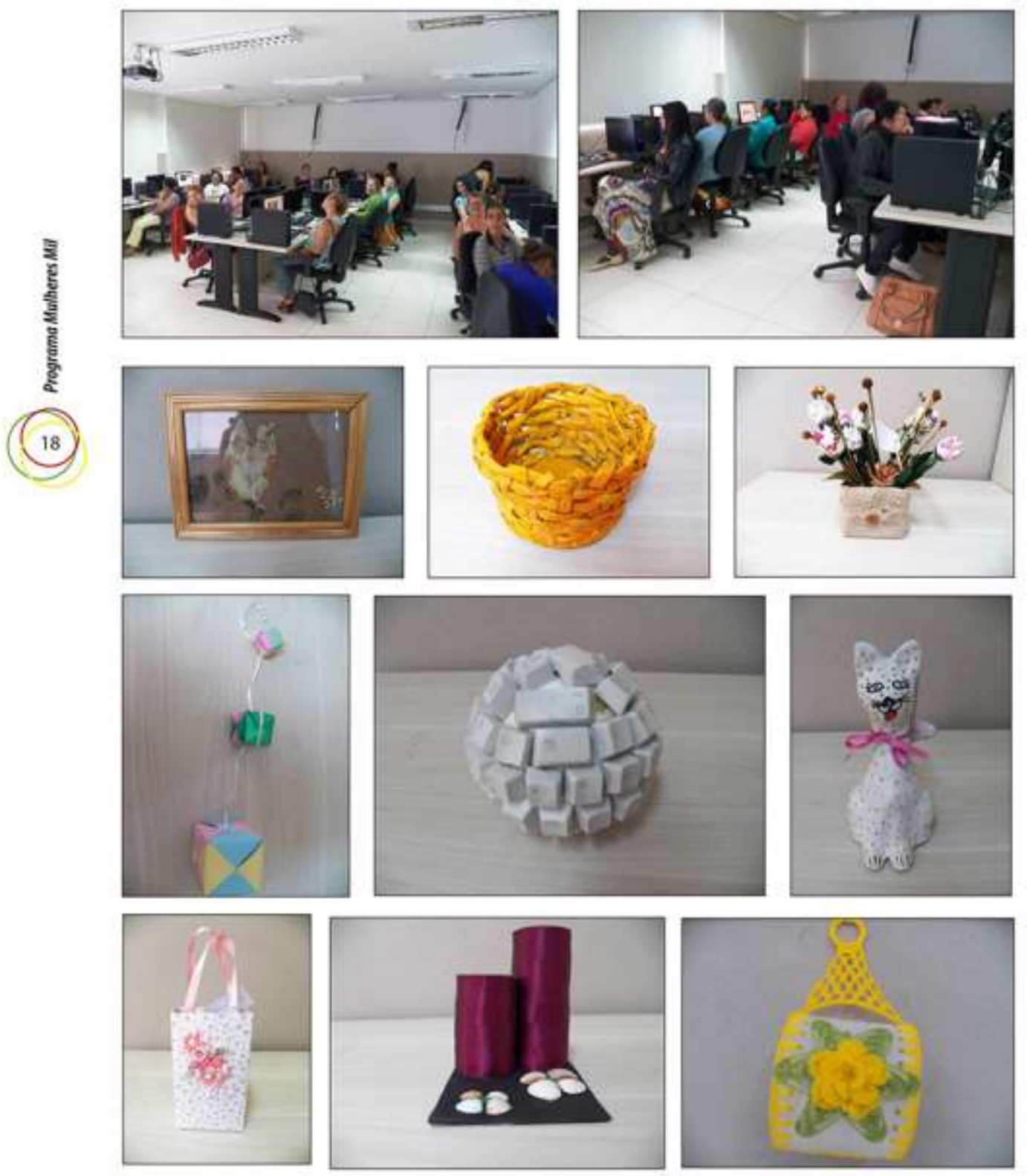




\section{Projeto Final}

A última componente do curso, ministrada pela professora Suzana Guerra, agregava um pouco de todas as componentes e levou às alunas uma metodologia de projeto para o desenwolvimento de novos produtos. Ela ocorreu em novembro e dezembro e as alunas eram livres para desenvolver o que quisessem, desde que utilizassem residuos sólidos na composiçăo das peças.

No último dia de aula, além das Mulheres Mil apresentarem seus projetos, elas tiveram a oportunidade de falar sobre 0 curso e as mudanças que ele trouxe para suas vidas. Neste mesmo dia elas receberam os mapas da vida e puderam refletir novamente sobre suas trajetórias de vida.
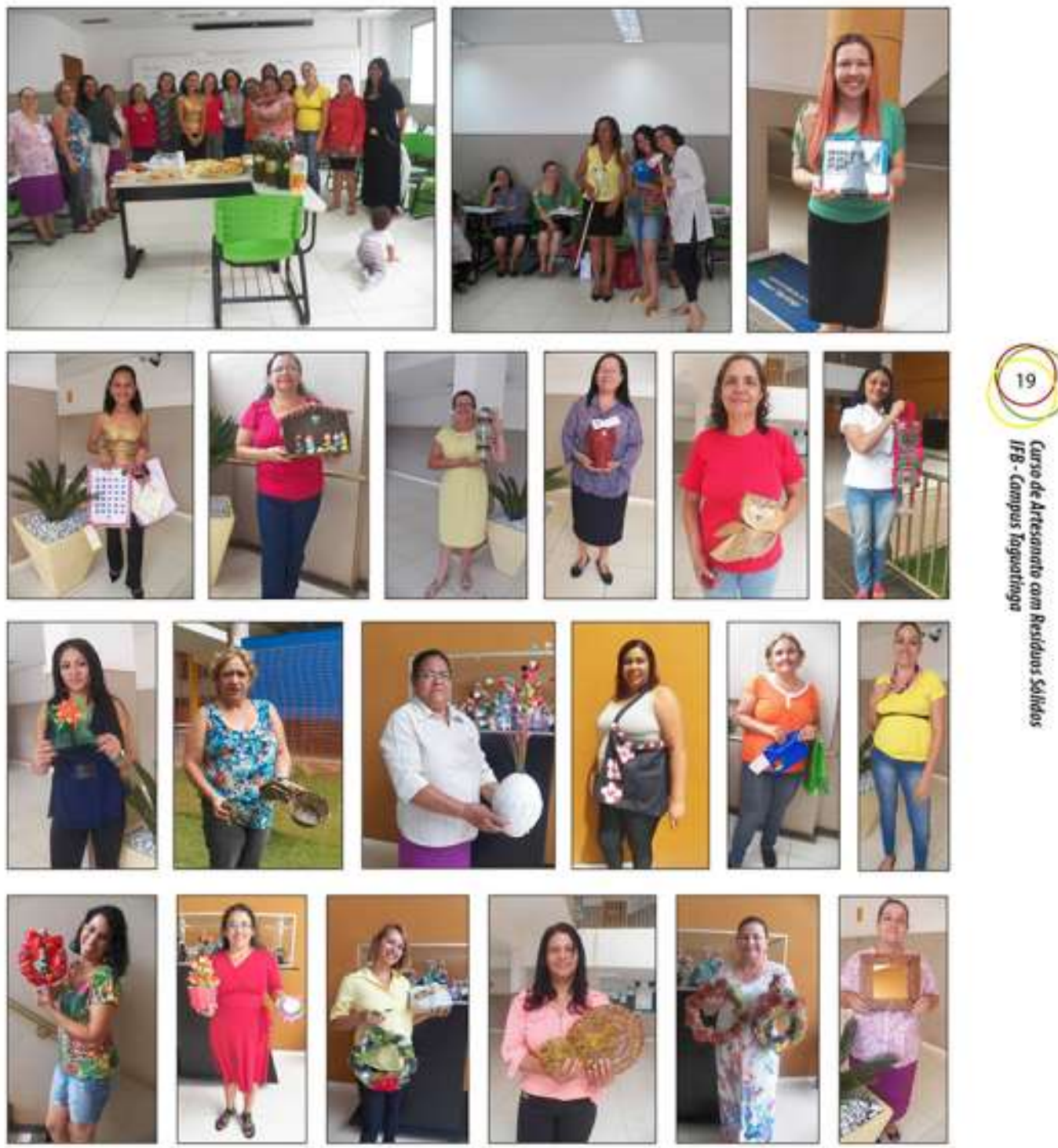

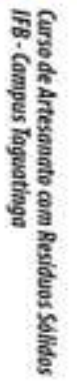




\section{Exposiçöes}

Ao longo do ano, as peças das alunas do curso de Artesanato com Residuos Sólidos foram expostas nos seguintes eventos:

- VII Encontro Nacional de Estudos Dirigidos para Mulheres (Enedim), nos dias 14 e 15 de maio, no Taguaparque;

- Feira de Educaçăo Profissional e Tecnológica (Fepet), nos dias 24 a 26 de junho, no Pátio Brasil Shopping:

- ॥Fórum Distrital de Educação Profissional e Tecnológica Inclusiva, de 26 a 29 de agosto, no Centro Cultural de Brasilia - CCB:

- $\|$ Evento Cultural Cientifico do Campus Taguatinga (ECC), dia $1^{\circ}$ de novembro, no Campus Taguatinga do IFB;

- Fórum Mundial de Direitos Humanos (FMDH), de 10 a 13 de dezembro, no Centro intemacional de Convençōes do Brasil-CICB.
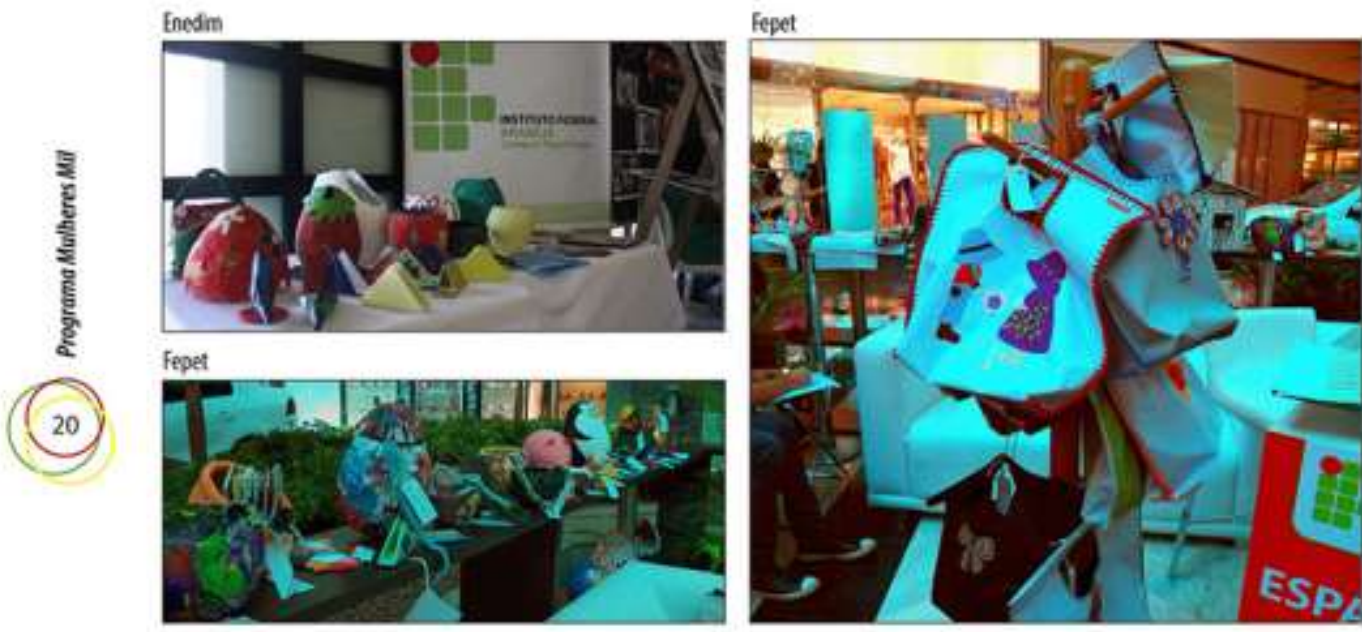

II Finum Distrital de Educacáo Profissional e Tecnoibgica Indusha
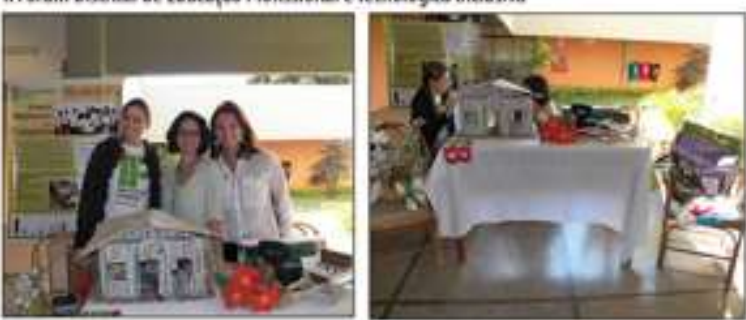

ECC Compus Taguatinga
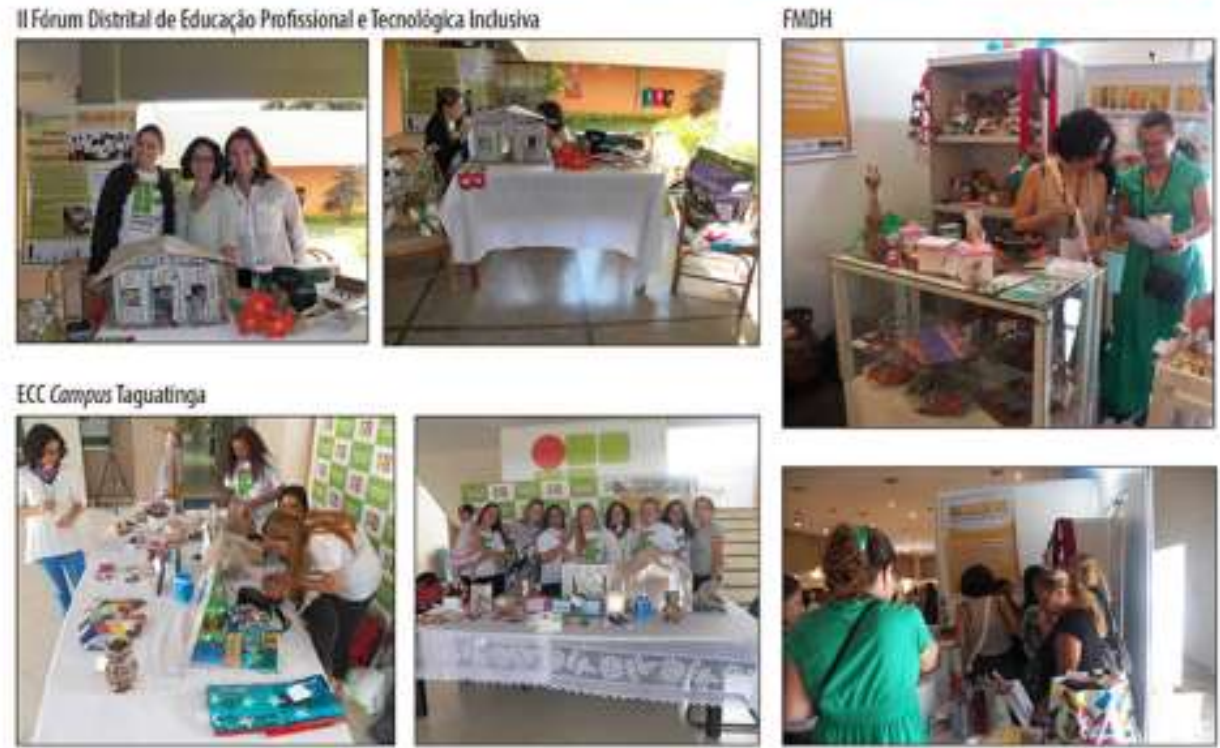


\section{Workshop Mulheres Mil}

Nos dias 30 e 31 de outubro, no Campus Planaltina do IFB, foi realizado o II Workshop Mulheres Mil, reunindo profissionais que trabalham diretamente com o programa.

0 evento mostrou as açoes do Programa e teve a participaçāo de gestores de IFs do Centro-Oeste e de alunas dos cursos de Mulheres Mil no IFB.

As alunas do Compus Taguatinga ministraram duas oficinas de artesanato com residuos sólidos: broche/presilha com flor de retalho de cetim, e pulseira com retalho de malha.

A aluna Maria da Conceição Alves de Castro, conhecida por todos como Rosa, deu seu depoimento sobre o curso. Alunas do Programa Mulheres Mil de outros Campi também deram seus depoimentos.
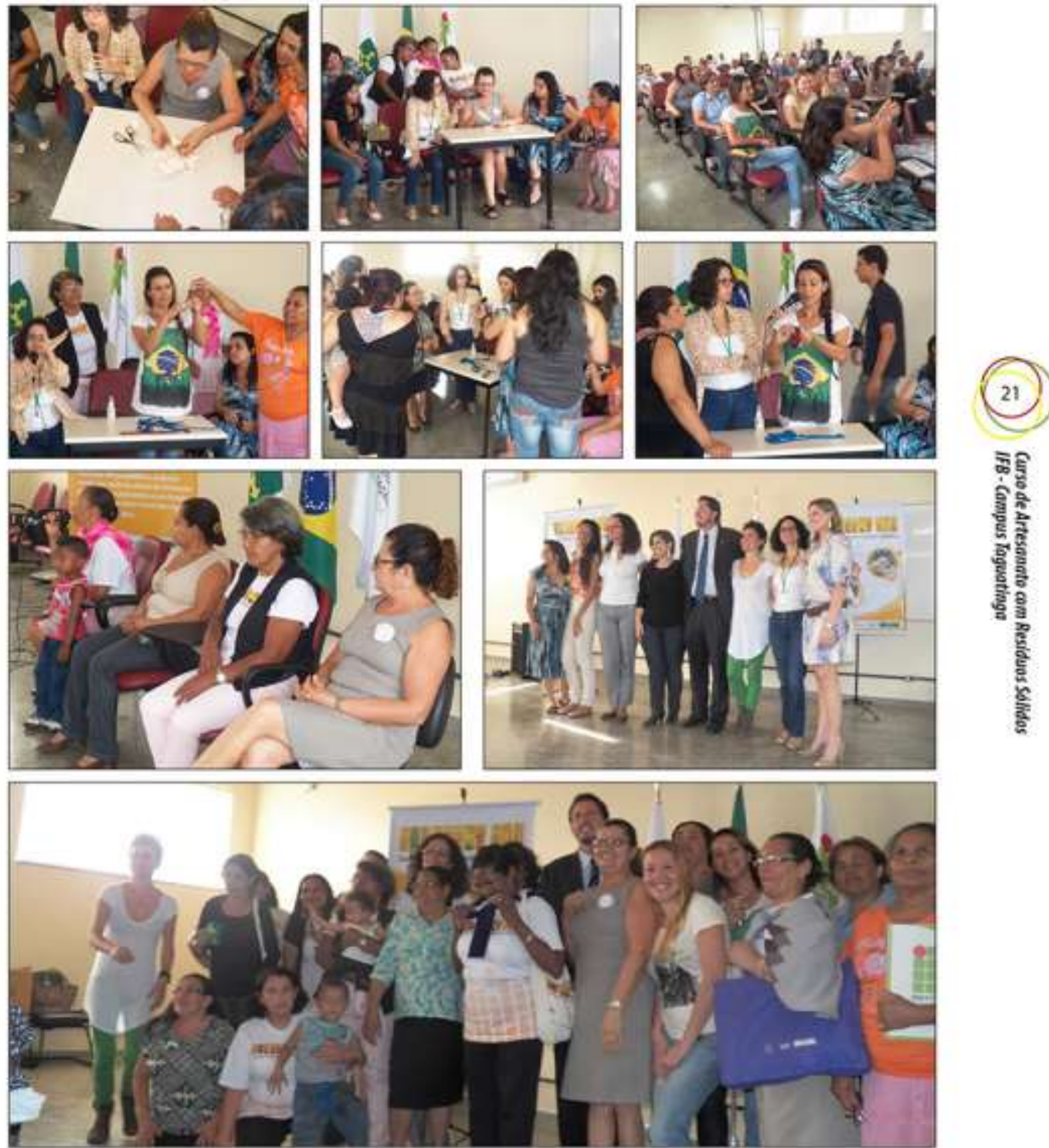


\section{Minicurso de Dança}

As Mulheres Mil participaram de minicurso de dança ministrado pelas alunas do curso de Licenciatura em Dança do Campus Brasilia Lidiane Ramos, Janaina Moraes, Amanda Rosa e Lisiane Queiroz.

0 curso, que também foi oferecido aos demais campi que tèm o programa Mulheres Mil, foi idealizado pelo Coordenador de Pesquisa e Extensão do Campus Brasilia Diego Pizarro e coordenado pelas professoras Cinthia Nepomuceno Xavier e Carla Sabrina Cunha. A experiência já é válida como estágio para as futuras professoras.

A experiência da dança foi transformadora para as alunas, que descobriram novas formas de linguagem e autoconhecimento por meio do movimento e expressāo de seus corpos.

As aulas ocorreram às segundas-feiras no Campus Brasilia, nos meses de junho e julho.
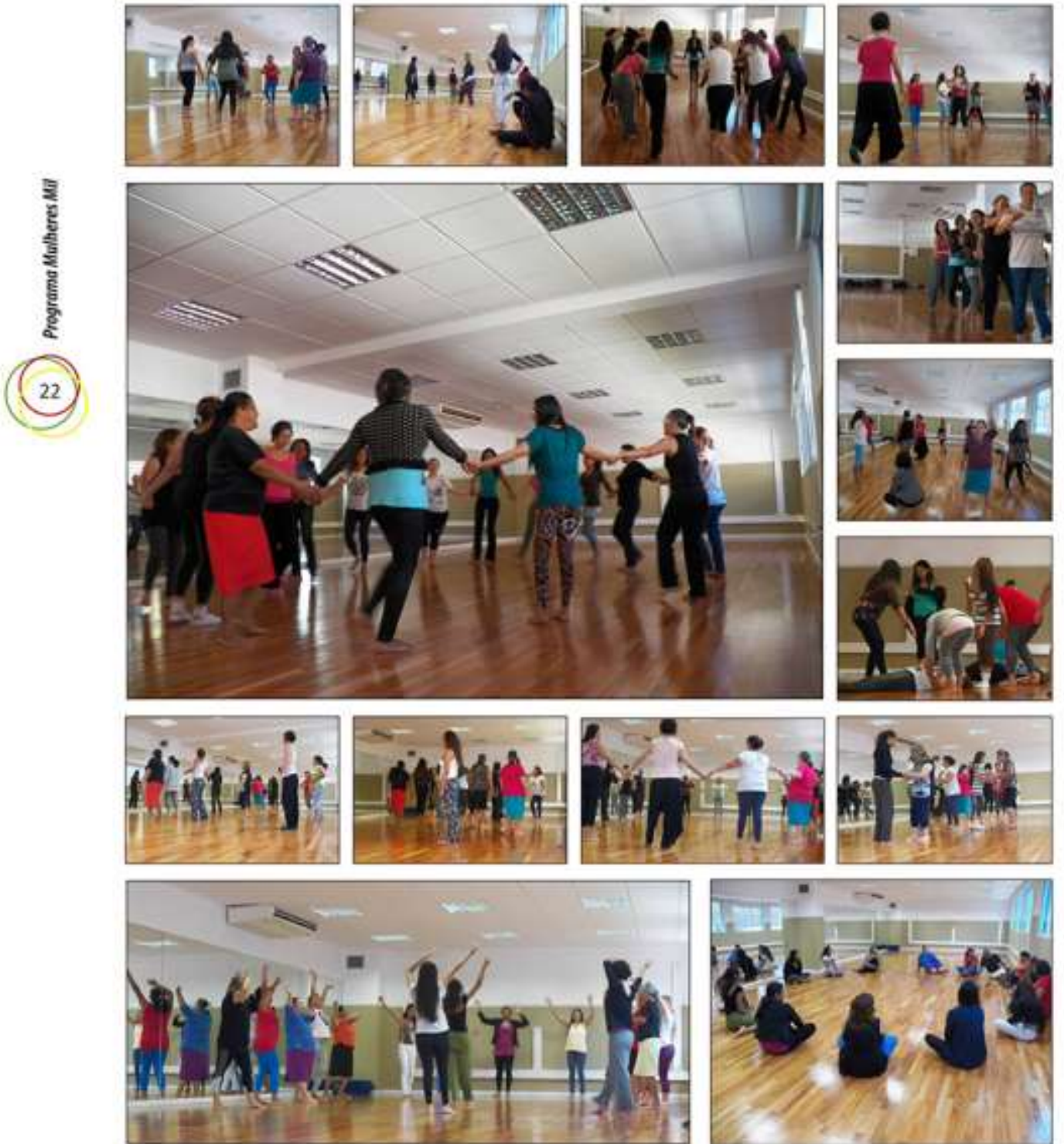


\section{Visitas Técnicas}

As visitas técnicas são atividades complementares com objetivos culturais e profissionais.

As Mulheres Mil tiveram as seguintes visitas técnicas:

- 7’ Feira Internacional de Artesanato (Finnar), no dia 15 de abril, no Centro de Convençōes Ulysses Guimarães, com a professora Suzana Guerra;

- Feira de Educaçăo Profissional e Tecnológica (Fepet), no dia 26 de junho, no Pátio Brasil Shopping, com a professora Suzana Guerra;

- Feira de Artesanato da Torre de TV, no dia 24 de agosto, com a professora Suzana Guerra;

- Congresso Nacional (Càmara e Senado), no dia 18 de setembro, com a professora Suzana Guerra. A programaçăo incluiu visita a 0 Plenário do Senado, Salão Nobre da Cămara e a exposiçăo "O Império em Brasilia";

- Centro Cultural Banco do Brasil (CCBB), no dia 25 de setembro, com o professor José Oliver. A visita incluiu a exposição de fotos "Um olhar sobre o Brasil";

- IFB campus Planaltina, durante o II Workshop Mulheres Mil, no dia 31 de outubro, com a professora Suzana Guerra;

- $6^{\circ}$ Salăo Internacional do Artesanato, no dia 09 de novembro, no ExpoBrasilia Parque da Cidade, com a professora Juliana Rangel;

- Fórum Mundial de Direitos Humanos (FMDH), no dia 10 de dezembro, no Centro Internacional de Convençôes do Brasil- CICB, com a professora Suzana Guerra.

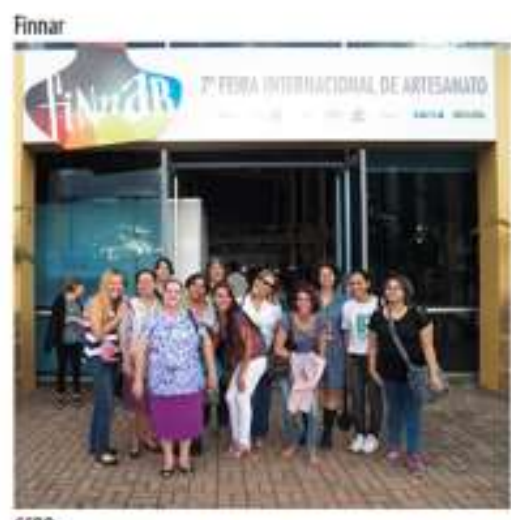

CCB8

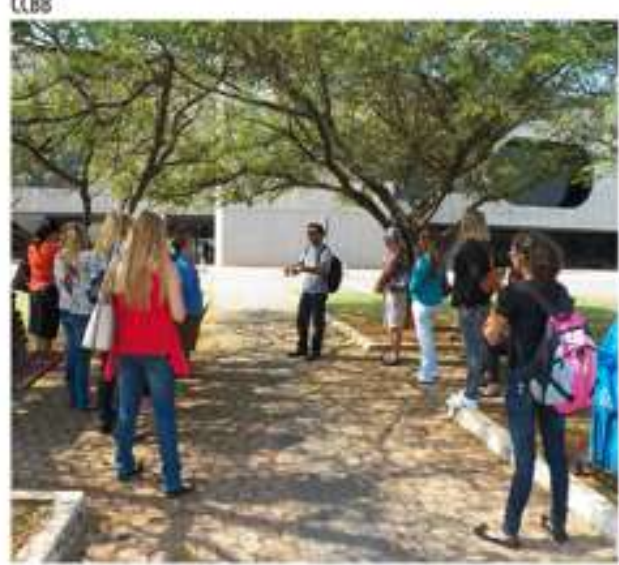

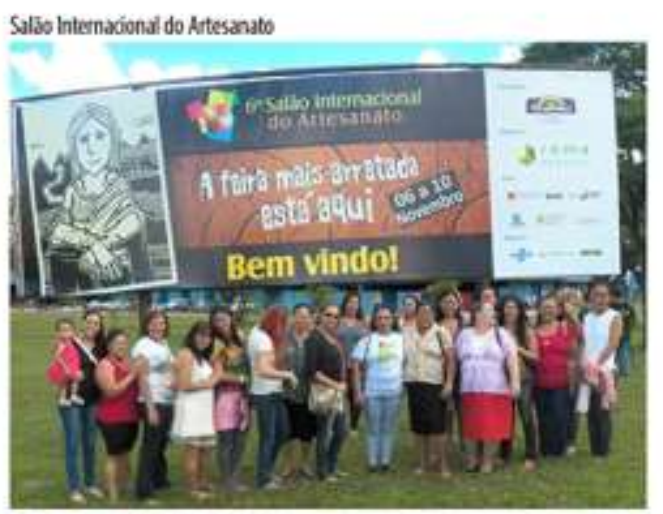

Congresso Nacianal

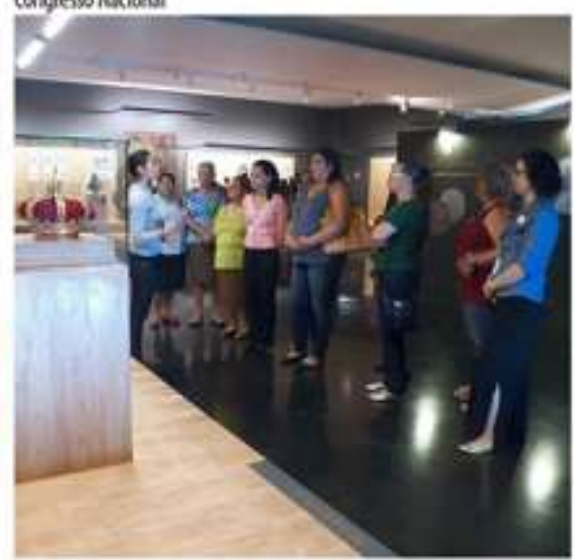

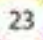

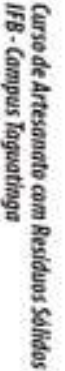




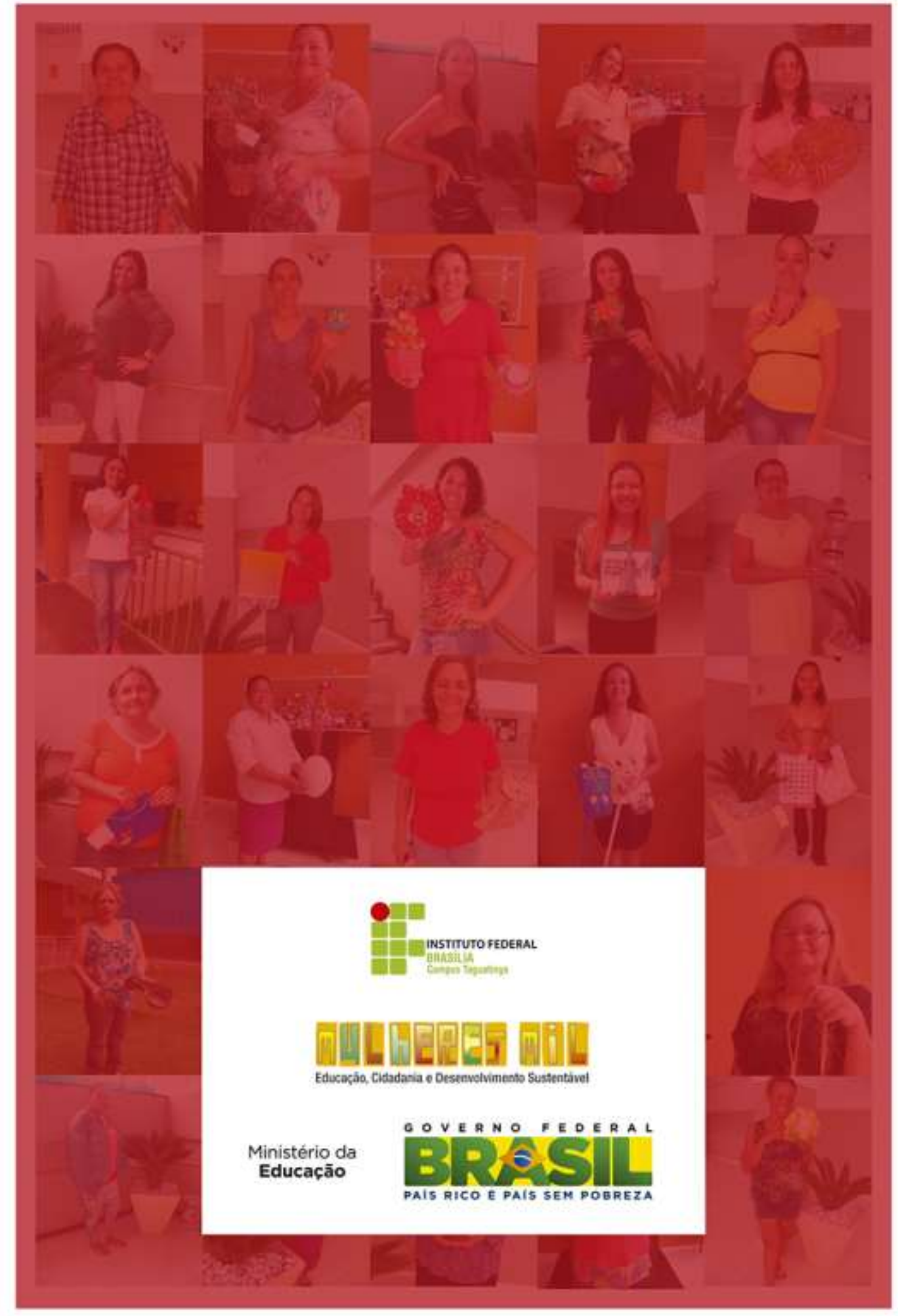

